\title{
Characterization of Geologic Deposits in the Vicinity of US Ecology, Amargosa Basin, Southern Nevada
}

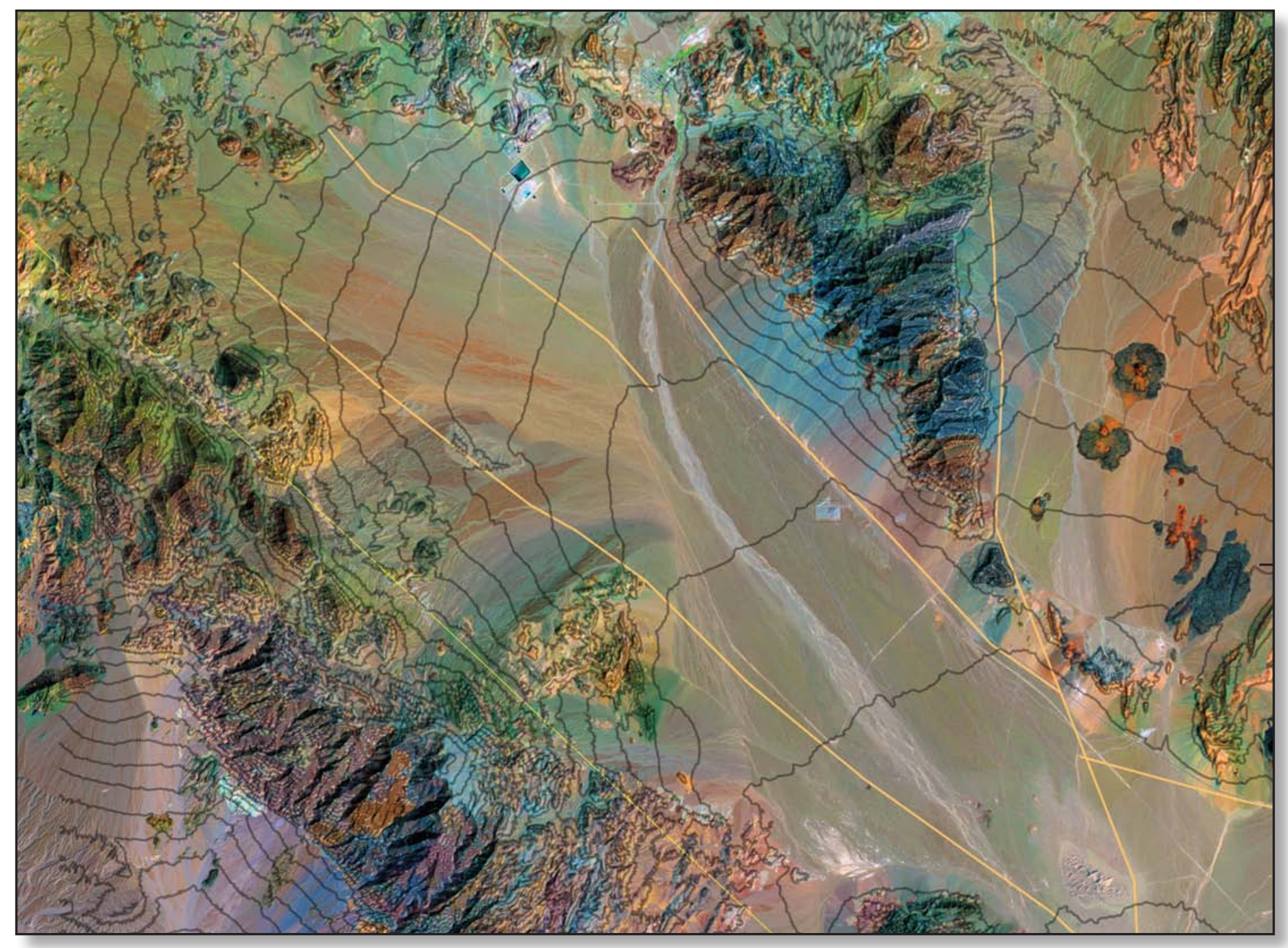

Scientific Investigations Report 2010-5134 
Cover: LANDSAT5 Satellite image of the vicinity of US Ecology, Armargosa Basin, southern Nevada. 


\section{Characterization of Geologic Deposits in the Vicinity of US Ecology, Amargosa \\ Basin, Southern Nevada}

By Emily M. Taylor

Scientific Investigations Report 2010-5134 


\title{
U.S. Department of the Interior \\ KEN SALAZAR, Secretary \\ U.S. Geological Survey \\ Marcia K. McNutt, Director
}

\section{U.S. Geological Survey, Reston, Virginia: 2010}

\author{
For more information on the USGS — the Federal source for science about the Earth, its natural and living resources, \\ natural hazards, and the environment, visit http://www.usgs.gov or call 1-888-ASK-USGS \\ For an overview of USGS information products, including maps, imagery, and publications, \\ visit http://www.usgs.gov/pubprod \\ To order this and other USGS information products, visit http://store.usgs.gov
}

\begin{abstract}
Any use of trade, product, or firm names is for descriptive purposes only and does not imply endorsement by the U.S. Government.

Although this report is in the public domain, permission must be secured from the individual copyright owners to reproduce any copyrighted materials contained within this report.
\end{abstract}

Suggested citation:

Taylor, E.M., 2010, Characterization of geologic deposits in the vicinity of US Ecology, Amargosa Basin, southern Nevada: U.S. Geological Survey Scientific Investigations Report 2010-5134, 194 p. 


\section{Contents}

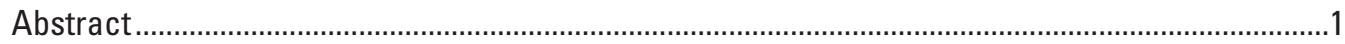

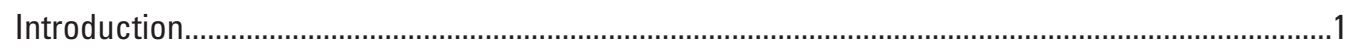

Surficial Geology of the Upper Amargosa River Valley.....................................................................

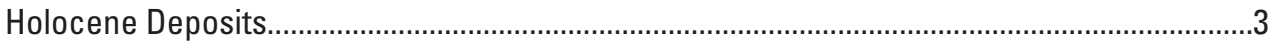

Late Pleistocene to Early Holocene Deposits ............................................................................

Late and Middle Pleistocene Deposits ....................................................................................

Early Pleistocene and Pliocene (?) Deposits .............................................................................

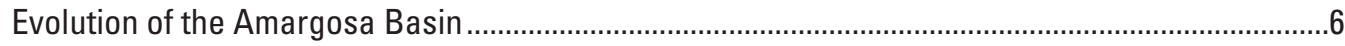

Estimated Rates of Basin Aggradation in the Vicinity of US Ecology .............................................7

Three-Dimensional Lithologic Model of the Subsurface Geology ..................................................10

Comparison of Direct Current Resistivity Profile Data to the Three-Dimensional Lithologic Model .................................................................................................................... 14

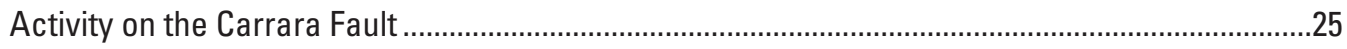

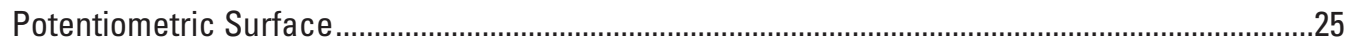

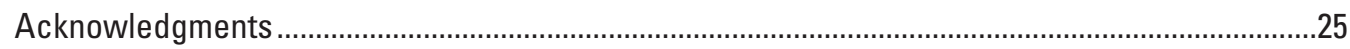

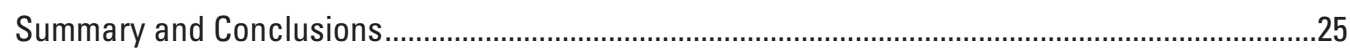

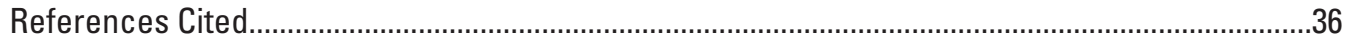

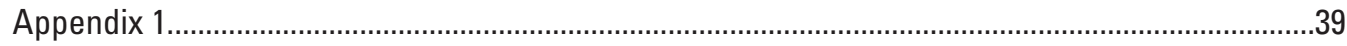




\section{Figures}

1. LANDSAT 5 satellite image of the vicinity of US Ecology …...........................................

2. Map showing the vicinity of the Amargosa Desert Research Site ....................................

3-6.-Graphs showing:

3. Rates of sediment accumulation in comparison to depth of sample ..........................8

4. Sediment age in comparison to depth of sample ..................................................

5. Rates of sediment accumulation in comparison to age of sample ...............................

6. Frequency of borehole depths .......................................................................12

7. Photograph showing Trench 11 at US Ecology........................................................15

8. Map showing locations of boreholes, fence diagram, and mapped faults .....................16

9. Lithologic fence diagram of the deposits below US Ecology.........................................17

10. Distribution of sediments in the three-dimensional lithologic model that are predominantly $(A)$ coarse sand and gravel, $(B)$ sandy, $(C)$ clayey lithologies .................18

11. Location of resistivity lines, fence diagram, and model boundary................................20

12. Comparison of the resistivity profiles (top) to the lithology profiles (bottom) ..................21

13. Contoured surface map to locate the Carrara Fault, trench locations, and projected Carrara Fault strand ..............................................................................26

14. Comparison of $(A)$ lithology model and $(B)$ Schlumberger sounding at the location of the inferred splay of the Carrara Fault ............................................................................27

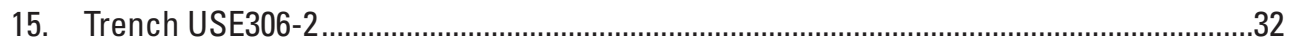

16. Exposure of the Carrara Fault in Trench USE306-7 $(A)$ centered in the fault

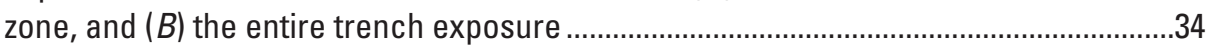

17. Comparison of the long-term average and the time-dependent water elevation ............35

\section{Tables}

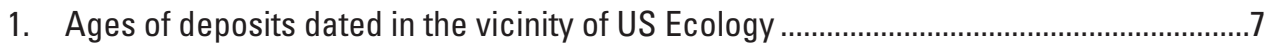

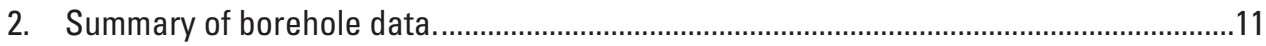

3. Simplified drillers' descriptions used to construct the lithologic model ..........................13

4. Soil unit descriptions of deposits exposed in trenches USE306-2, 5, and 7 ....................28 


\section{Conversion Factors}

SI to Inch/Pound

\begin{tabular}{lll}
\hline \multicolumn{1}{c}{ Multiply } & \multicolumn{1}{c}{ By } & \multicolumn{1}{c}{ To obtain } \\
\hline centimeter $(\mathrm{cm})$ & \multicolumn{1}{c}{ Length } \\
millimeter $(\mathrm{mm})$ & 0.3937 & inch (in.) \\
meter $(\mathrm{m})$ & 0.03937 & inch (in.) \\
kilometer $(\mathrm{km})$ & 3.281 & foot (ft) \\
meter $(\mathrm{m})$ & 0.6214 & mile (mi) \\
& 1.094 & yard (yd) \\
\hline millimeter per year $(\mathrm{mm} / \mathrm{yr})$ & 0.03937 & Flow rate \\
\hline
\end{tabular}

Temperature in degrees Celsius $\left({ }^{\circ} \mathrm{C}\right)$ may be converted to degrees Fahrenheit $\left({ }^{\circ} \mathrm{F}\right)$ as follows:

$$
{ }^{\circ} \mathrm{F}=\left(1.8 \mathrm{x}^{\circ} \mathrm{C}\right)+32
$$

Vertical coordinate information is referenced to the North American Vertical Datum of 1988 (NAVD 88).

Horizontal coordinate information is referenced to the North American Datum of 1927 (NAD 27).

Elevation, as used in this report, refers to distance above the vertical datum.

\section{Abbreviations and Acronyms}

$\begin{array}{ll}\text { ADRS } & \text { Amargosa Desert Research Site } \\ \text { GPS } & \text { Global Positioning System } \\ \text { IRSL } & \text { Infrared Stimulated Luminescence } \\ \text { OSL } & \text { Optically Stimulated Luminescence } \\ \text { TL } & \text { Thermoluminescence } \\ \text { USE } & \text { US Ecology } \\ \text { ka } & \text { thousand years } \\ \text { m.y. } & \text { million years }\end{array}$





\title{
Characterization of Geologic Deposits in the Vicinity of US Ecology, Amargosa Basin, Southern Nevada
}

\author{
By Emily M. Taylor
}

Abstract

Multiple approaches have been applied to better understand the characteristics of geologic units exposed at the surface and buried at depth in the vicinity of US Ecology (USE), a low-level commercial waste site in the northern Amargosa Desert, Nevada. Techniques include surficial geologic mapping and interpretation of the subsurface using borehole data. Dated deposits at depth were used to estimate rates of sediment accumulation. The subsurface lithologies have been modeled in three dimensions. Lithologic cross sections have been created from the three-dimensional model and have been compared to resistivity data at the same location. Where deposits appear offset, a fault was suspected. Global Positioning System elevation transects were measured and trenches were excavated to locate a strand of the Carrara Fault. The presence of the fault helps to better understand the shape of the potentiometric surface. These data will be used to better understand the hydrologic parameters controlling the containment of the waste at US Ecology.

Quaternary geologic units exposed at the surface, in the vicinity of US Ecology, are derived from the alluvium shed off the adjacent range front and the Amargosa River. These deposits vary from modern to early Pleistocene in age. At depth, heterogeneous sands and gravel occur. Observed in deep trenches and boreholes, the subsurface deposits are characterized as fining-upward sequence of sediment from 5- to 8-meters thick. No volcanic units or fine-grained playa deposits were described in the boreholes to a depth of 200 meters. Based on Infrared Stimulated Luminescence dated core samples, short-term rates of sediment accumulation $(<70,000$ years) are an average of 2.7 millimeters per year, however, long-term rates $(<3,900,000$ years $)$ are orders of magnitude less. Resistivity data, when compared to lithologic cross sections, generally are consistent with lithology grain size and probable soil carbonate accumulations. Surface resistivity displays a fining-upward sequence of sediments at the surface with a soil carbonate imprint. Finally, trenching north of US Ecology successfully exposed offset Quaternary deposits on a splay of the Carrara Fault. Holocene deposits do not appear to be faulted, however, a fault zone does intersect middle and late Pleistocene aged units.

\section{Introduction}

US Ecology (USE) is a low-level waste site located about 17 kilometers $(\mathrm{km})$ southeast of Beatty, Nevada, in the Amargosa Desert. The waste site is a fenced rectangle of land measuring approximately 400 by 800 meters (m) on the floor of the Amargosa River Valley. It is flanked to the east by Bare Mountain and to the west by the modern Amargosa River. Detailed site monitoring is done by the U.S. Geological Survey (USGS) at the Amargosa Desert Research Site (ADRS), located just outside the southwest corner of USE. ADRS is monitored to track any possible movement of the waste beyond the facility (fig. 1).

The purpose of this report is to better understand the hydrologic parameters controlling the containment of the waste. Several geologic, hydrologic, and geophysical studies have been completed to better understand the evolution of the Amargosa Basin, in the vicinity of ADRS. Techniques from these studies will be integrated to characterize the study area. These numerous techniques include surficial geologic mapping and reconstruction of the subsurface using borehole data. The subsurface lithologies have been modeled in three dimensions. Lithologic sections have been created from the three-dimensional model and have been compared to resistivity data at the same location. Where deposits appear offset, a fault was suspected. Global Positioning System (GPS)-elevation transects were measured and trenches were excavated to locate a strand of the Carrara Fault. The presence of the fault helps to better understand rises in the potentiometric surface.

\section{Surficial Geology of the Upper Amargosa River Valley}

The most detailed surficial map of the study area was made in 1988 by Swadley and Parrish (1988) who had been producing Quaternary geologic maps as part of the proposed high-level nuclear waste site at Yucca Mountain, which is located $19 \mathrm{~km}$ to the west. Swadley contributed to mapping that extended from the Amargosa Desert, north to Pahute 


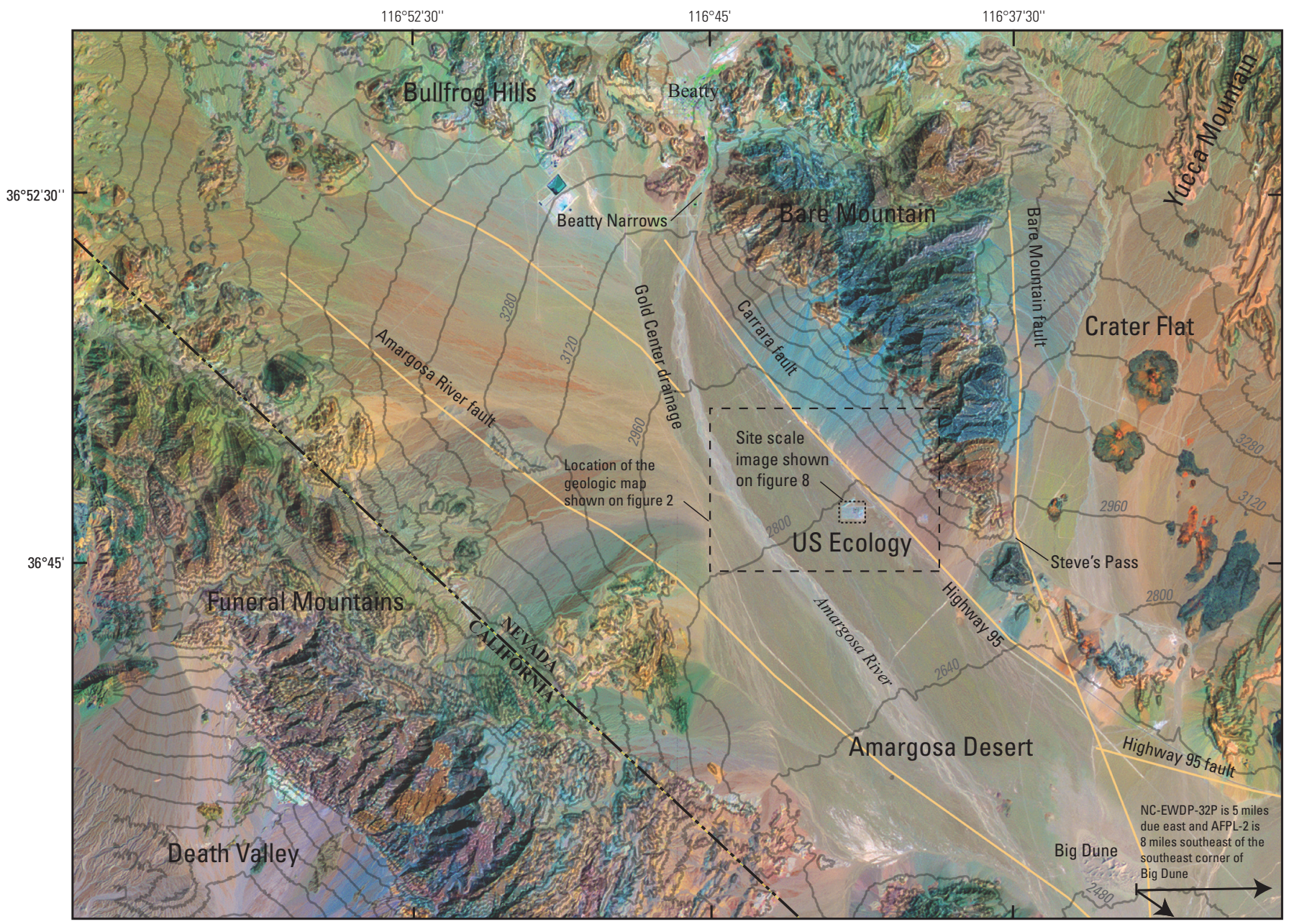

Contour Interval = 160 feet (approximately 50 meters)

Combining LANDSAT 5 spectral bands 2, 5 and 7 in RGB space created this false-color composite image. Individual bands were processed to display their full dynamic range. The image was further processed in hue-saturation space to emphasize specific geologic feature On the image, bedrock exposures of carbonate rocks appear in shades of blue and green and rhyolitic volcanic rocks are in shades of tan and orange. Basaltic rocks in Crater Flat appear as discrete nearly black features surrounded by basin fill, which appears as smooth multi-colored deposits. Active drainages are light blue. The area is sparsely vegetated.

\section{EXPLANATION}

_ Fault (from Workman and others, 2002)
_... State boundary
......... US Ecology boundary

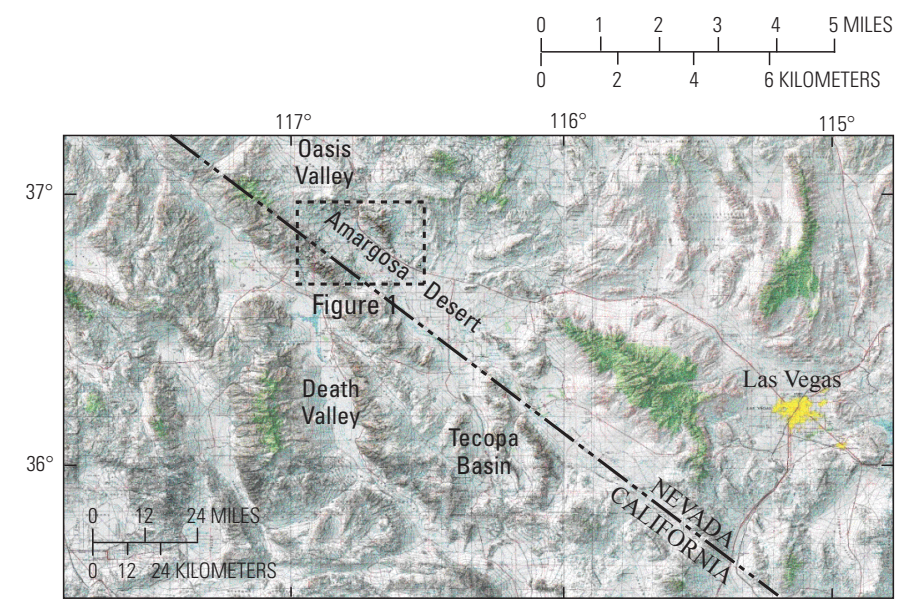

Index Map

Figure 1. LANDSAT 5 satellite image of the vicinity of US Ecology. This satellite image has been processed to enhance the surficial Quaternary geologic units. In some cases, particularly on the southwest flanks of Bare Mountain, similar-aged deposits vary in color from blue to purple because the alluvium is composed of different rock types. Typically, however, the older, elevated fans are darker because of the dense well-packed desert pavement and the modern washes are light. 
Mesa, and east to the Specter Range. This mapping was completed at a scale of 1:12,000 in the field and published on a quadrangle scale of 1:24,000 (fig. 2). More recently the original nomenclature was changed to a numbering scheme (Keefer and others, 2004) and is included below in parentheses. Other regional maps have been made that include this area, but the geologic mapping units have been simplified from the original mapping and are not used here. The surficial geologic map units range in age from Holocene to Plio-Pleistocene - see Swadley and Parrish (1988) for more detailed descriptions.

\section{Holocene Deposits}

Q1ab (Q7-6) Alluvial deposits - gravel, gravelly sand, silty sand, and sandy silt. Forms active channel (Q1a) and low terrace deposit (Q1b), 1-2 $\mathrm{m}$ above the active drainage, where bar and swale topography is well expressed. Upper surface is periodically flooded. Little or no soil development. Q1 ab is less than $10-\mathrm{m}$ thick.

\section{Late Pleistocene to Early Holocene Deposits}

Q1s (Q5s) Alluvial sheet sand deposits-fluvially reworked sand that may contain scattered pebbles. Unit surface is smooth and typically less than 2-m thick. Q1s commonly overlies Q2c, Q2s, and Q1c deposits. Unit also is combined with Q2s and mapped as Q1s+Q2s where the features of Q1s are dominant to those of Q2s, but too subtle to subdivide in the field. Weak development of soil horizons and minor accumulation of secondary calcium carbonate on gravel clasts and disseminated in soil matrix.

Q1c (Q5) Alluvial deposit—gravel, gravelly sand, and silty sand. Clasts commonly are less than 30 centimeters $(\mathrm{cm})$ but adjacent to mountain front, clasts may exceed $1 \mathrm{~m}$ in diameter. Unit forms terraces along washes and alluvial fans on the flanks of Bare Mountain. Unit surface is subdued and lacks bar and swale topography. Incipient B horizon formation contains both accumulations of secondary carbonate on gravel clasts as well as soil "reddening" associated with clay illuviation.

\section{Late and Middle Pleistocene Deposits}

Q2bc (Q4-3) Alluvial gravel with a fine-grained matrix of sand and silt. Units cannot be subdivided on the basis of topographic position and geomorphic form. Unit forms terraces inset along some washes and alluvial fans on the flanks of Bare Mountain. Q2bc is frequently buried by Q1c, and is preserved as patchy outcrops in the basin axis. These outcrops are distinguished by the well-packed and well-sorted pavement surface. Clasts as large as $0.5 \mathrm{~m}$ are common in range front fans. Soils have well-developed calcium-carbonate-rich horizons that form dense zones of cemented sand and gravel.

Q2s (Q3s) Alluvial sheet sand deposits. Sand and minor gravel up to 10 percent. Unit also is combined with Q1s and mapped as $\mathrm{Q} 2 \mathrm{~s}+\mathrm{Q} 1 \mathrm{~s}$ where the features of Q2s are dominant to those of Q1s, but too subtle to subdivide in the field. Unit typically is a thin mantle of reworked eolian and fluvial sands with a soil characterized by disseminated calcium carbonate in well-developed soil horizons. Gravel are coated in carbonaterich horizons.

\section{Early Pleistocene and Pliocene (?) Deposits}

QTa (Q1) Alluvial and minor colluvial deposits. Poorly-sorted gravel deposited as alluvial fans that now form gently rounded ridges on the Bare Mountain range front and a discrete mound east and south of USE. The knoll has exposed bedrock on its northeast side adjacent to Highway 95, but is draped by QTa aged gravel. The surface, where the pavement has not been eroded, contains discrete, white, silica platelets. These platelets are derived from the eroded densely cemented soil at depth. The white platelets are distributed on the surface and incorporated into the well-packed pavement. The soil is characterized by laminar accumulations of secondary calcium carbonate, and is further cemented by dense amorphous silica derived from the dissolution of the ash-rich volcanic rocks. The deposit typically is stripped down to the top of this cemented zone, or stripped and blanketed with a thin sequence of young eolian fines that support the desert pavement.

The exposed surficial geology in the vicinity of ADRS is characterized by four Quaternary/Tertiary depositional environments (Swadley and Parrish, 1988, Keefer and others, 2004) (fig. 2). The first environment is range front alluvial fan assemblages that prograde into the Amargosa Basin. These fans occur east of USE on the flanks of Bare Mountain. The fans range in age from Plio-Pleistocene to Holocene and typically are coarsegrained gravel shed as debris flows. The oldest fans are highest in elevation, with the progressively younger fans inset below. The secondly depositional environment is an axial drainage system controlled by the Amargosa River and the Gold Center drainages, which introduce exotic alluvium into the basin from upstream. Exotic alluvium is derived from bedrock that does not occur in the mountains surrounding the Amargosa Basin, but bedrock found in distant mountain ranges and transported and deposited into the Amargosa Basin. The axial drainage deposits contain basalt clasts that are lacking in the locally derived fans. These predominantly Pleistocene deposits typically are coarse sand and gravel and are rarely exposed at the surface. The third depositional component, exposed at the surface, is eolian or reworked eolian sediments derived from once-active drainages, exposed playa sediments, and groundwater or palustrine deposits. These fine-grained sediments provide an important and ubiquitous component to the surficial deposits, both as infiltrated fines and surface deposits. This fine-grained unit contains little or no reworked gravel clasts. Where this unit occurs as Holocene sheet wash, it typically is about 1-m thick and buries the older alluvium. The sheet wash occurs as thin darkly pavemented terraces parallel to the active drainages (fig. 2). A fourth depositional component, not 

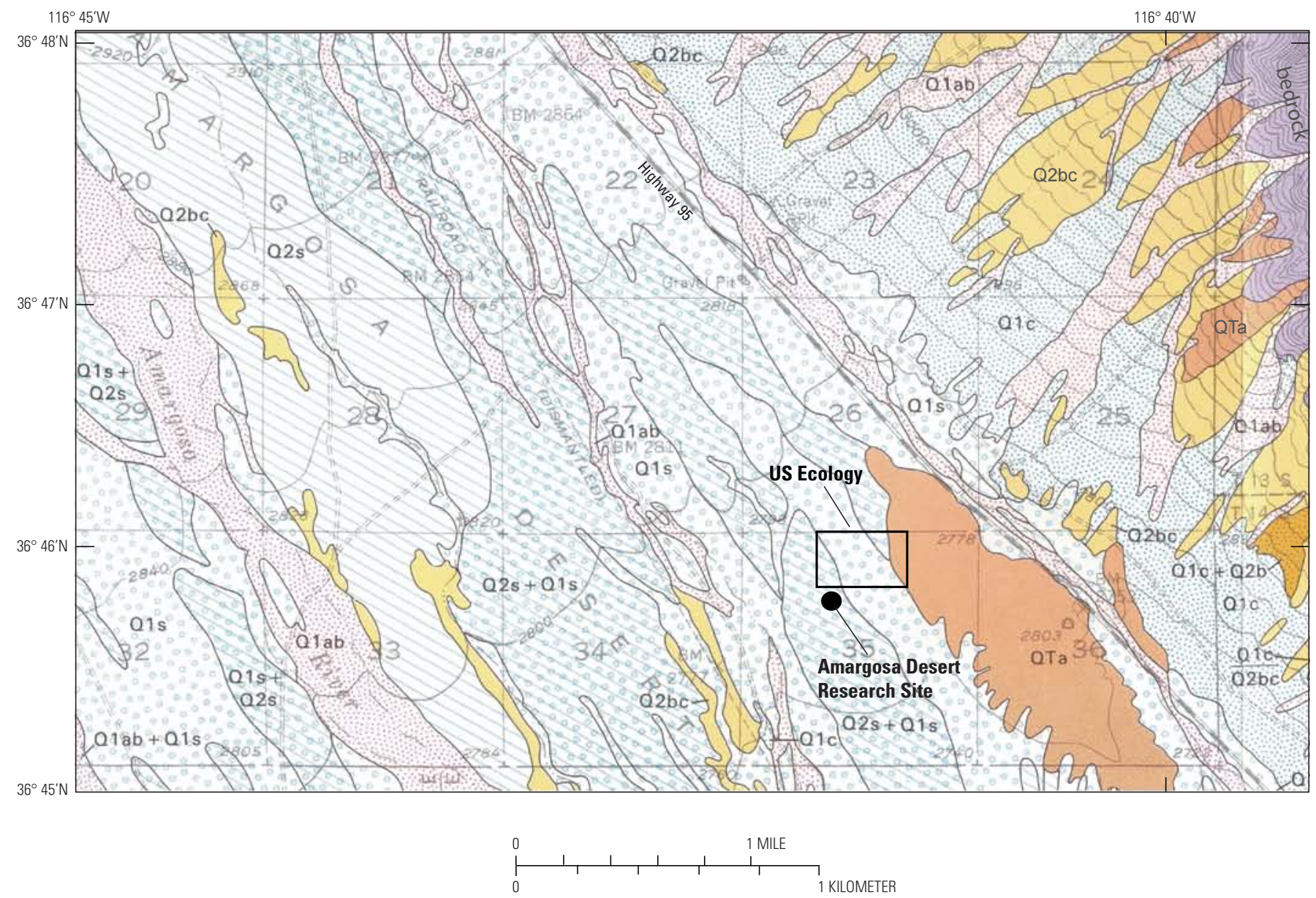

Figure 2. Vicinity of the Amargosa Desert Research Site. See Swadley and Parrish (1988) for more detailed descriptions. Unit in parentheses, in explanation on page 5, is unit nomenclature from Keefer and others, 2004. 


\section{EXPLANATION}

Holocene deposits:

Q1ab (Q7-6) Alluvial deposits - gravel, gravelly sand, silty sand and sandy silt. Forms active channel (Q1a) and low terrace deposit (Q1b), 1-2 meters above the active drainage, where bar and swale topography is well expressed. Upper surface is periodically flooded. Little or no soil development. Q1ab is less than 10-meter thick.

Late Pleistocene to early Holocene:

Q1s (Q5s) Alluvial sheet sand deposits-fluvially reworked sand that may contain scattered pebbles. Unit surface is smooth and typically less than 2-meters thick. Q1s commonly overlies Q2c, Q2s and Q1c deposits. Unit also is combined with Q2s and mapped as Q1s+Q2s where the features of Q1s are dominant to those of Q2s, but too subtle to subdivide in the field. Weak soil horizonation and minor accumulation of secondary calcium carbonate on gravel clast and disseminated in soil matrix.

Q1c (Q5) Alluvial deposit — gravel, gravelly sand, and silty sand. Clast commonly are less than $30 \mathrm{~cm}$ but adjacent to mountain front, clasts may exceed 1 meter in diameter. Unit forms terraces along washes and alluvial fans on the flanks of Bare Mountain. Unit surface is subdued and lacks bar and swale topography. Incipient B horizon formation contains both accumulations of secondary carbonate on gravel clasts as well as soil "reddening" associated with clay illuviation.

Late and middle Pleistocene deposits:

Q2bc (Q4-3)-Alluvial gravel with a fine-grained matrix of sand and silt. Units cannot be subdivided on the basis of topographic position and geomorphic form. Unit forms

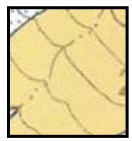
terraces inset along some washes and alluvial fans on the flanks of Bear Mountain. Q2bc frequently is buried by Q1c, and is preserved as patchy outcrops in the basin axis. These outcrops are distinguished by the well-packed and well-sorted pavement surface. Larger clasts up to 0.5 meter are common in range front fans. Soils have well-developed calcium carbonate rich horizons that form dense zones of cemented sand and gravel.

Q2s (Q3s) - Alluvial sheet sand deposits. Sand and minor gravel up to 10 percent. Unit also is combined with Q1s and mapped as Q2s+Q1s where the features of Q2s are dominant to those of Q1s, but too subtle to subdivide in the field. Unit typically is a thin mantle of reworked eolian and fluvial sands with a soil characterized by disseminated calcium carbonate in well-developed soil horizons. Gravel are coated in carbonate rich horizons.

Early Pleistocene and Pliocene (?) deposits:

QTa (Q1)-Alluvial and minor colluvial deposits. Poorly sorted gravel deposited as alluvial fans that now form gently rounded ridges on the Bare Mountain range front and a discrete mound east and south of US Ecology. The knoll has exposed bedrock on its northeast side adjacent to Highway 95, but is draped by QTa aged gravel. The surface, where the pavement has not been eroded, contains discrete, white, silica platelets. These platelets are derived from the eroded densely cemented soil at depth. The white platelets are distributed on the surface and incorporated into the well packed pavement. The soil is characterized by laminar accumulations of secondary calcium carbonate that is further cemented by dense amorphous silica derived from the dissolution of the ash-rich volcanic rocks. The deposit typically is stripped down to the top of this cemented zone, or stripped and blanketed with a thin package of young eolian fines that support the desert pavement.

Undifferentiated bedrock

Figure 2. Vicinity of the Amargosa Desert Research Site. See Swadley and Parrish (1988) for more detailed descriptions. Unit in parentheses, in explanation above, is unit nomenclature from Keefer and others, 2004.-Continued 
exposed at the surface in the vicinity of USE, is the uniform fine-grained groundwater discharge or playa deposits. They are a primary source of the locally derived eolian component. These deposits may contain thin gravel beds derived from alluvial fans or active drainages, or both, that have been deposited into the playa or palustrine environment. Both paleodischarge and playa sediments occur where water has intersected the land surface. All of the deposits described above locally have been reworked by surficial processes.

The fan assemblages that flank western Bare Mountain (fig. 2) indicate a quiescent range front. Active range fronts are draped with young fans because vertical uplift provides material that is eroded downslope (Bull, 1991). Strike-slip offset on the range-front fault creates offset drainages which are not observed in the study area. The projection of the Carrara Fault, discussed later, does not appear to offset any modern drainages. The predominantly Pleistocene fans are preserved at the range front because of basin subsidence or change in the active drainage gradient. Fans adjacent to the range front are incised and preserved, rather than buried by younger alluvium. The subsidence is either in the immediate Amargosa Basin or down gradient in basins connected to or captured by the Amargosa River.

The relative ages of the mapped units primarily are determined by the amount of soil development on each surface. The older units have thicker and denser accumulations of secondary soil carbonate. The time of fan formation and the isolation or shift in the drainage pattern on the fan, are reflected by the soils that have formed on the fan assemblages. Once alluviation ceases because the active drainage has incised the surface, either at the range front or associated with the axial drainages, abandoned surfaces begin to be affected by the process of soil formation. In the study area, the predominant soil forming process is the addition of eolian fines into gravelly alluvium, resulting in "plugged" depositional systems, and the subsequent accumulation of secondary soil carbonate. The soil carbonate is primarily derived from the dissolution and reprecipitation of carbonate from the eolian fines and limestone parent material. The location of the secondary soil carbonate is controlled by the wetting front. Greater amounts of secondary carbonate indicate greater relative age. However, once a unit is buried it is out of the zone of accumulation, so similar-aged deposits at depth will have less soil development than those that have been continually exposed at the surface. In the basin, deposits correlated to the fan deposits occur as narrow ridges above the modern Amargosa River (fig. 2).

The Amargosa and Gold Center River deposits are oriented in the basin perpendicular to the fan assemblages and parallel to the modern drainage (fig. 1). The basin deposits have truncated and interfingered with the range front fans as the Amargosa River periodically has migrated across the basin. Late Quaternary fine-grained sheet wash deposits overlie alluvial deposits that were previously exposed as terraces above the active washes. The older alluvium, with a welldeveloped soil, is located about $1 \mathrm{~m}$ below the surface and is nearly ubiquitous in exposures in the Amargosa Desert. This buried unit is coincident in age to the mid-Pleistocene high terrace at Fortymile Wash on the east side of Yucca Mountain (Potter and others, 2002) and predates the incision of Fortymile Canyon. The well-developed soil on this Pleistocene deposit represents a long period of surface stability in the late Quaternary, prior to the deposition of the fine-grained sheet wash deposit.

\section{Evolution of the Amargosa Basin}

The Amargosa Basin periodically has been internally drained, and the Amargosa River did not exit the basin in the past as it does today (Taylor and Sweetkind, 2010; Menges, 2008). The present Amargosa River flows from Oasis Valley, north of Beatty, through the Beatty Narrows into the Amargosa Desert. It continues southward out of the Amargosa Desert at Ash Meadows into the Tecopa Basin and eventually ends in Death Valley. Flow typically occurs seasonally with the exception of the Beatty Narrows and a small reach in the center of the basin, west of Stateline, where water intersects the surface year round.

The formation of the Amargosa Basin culminated around 10 m.y. (Fridrich and others, 2007). Volcanic rocks older than 10 m.y., have been faulted and no longer preserve the slope of the original ash-flow deposition. These Miocene volcanic rocks were deformed and tilted during the basin evolution. South of USE, volcanic tuffs and basalts often cap older rocks that form the mountains surrounding the Amargosa Basin.

Volcanic rocks younger that $10 \mathrm{~m}$.y. are flat lying and have not undergone deformation. The late Quaternary Lathrop Wells cone and the Pliocene basalt flows in Crater Flat are examples of these undeformed young volcanic rocks.

The Amargosa Basin was internally drained until the Amargosa Narrows connected Oasis Valley to the Amargosa Basin in late middle Pleistocene time (Menges, 2008). Prior to the downcutting at the Amargosa Narrows, basin fill was exclusively derived from the ranges surrounding the Amargosa Basin. After the integration of the Amargosa River, alluvial sediments from outside the basin margins were introduced and incorporated into the local lithologies. Exotic basalt fragments, derived from eruptive centers north of Oasis Valley are on the surface and incorporated into the surficial basin deposits. Although sediment entered the system from the headwaters of the Amargosa River in Oasis Valley, and minor surrounding drainages, a period of time existed when material was added to the Amargosa Basin from the north, but the river did not exit the Amargosa Basin (Taylor and Sweetkind, 2010). The Tecopa and Amargosa Basins were not integrated until the Amargosa River breached at the Eagle Mountain narrows, south of Ash Meadows, between 150-50 ka (Menges, 2008). The elevation difference between the Ash Meadows area and the Tecopa Basin is less than $20 \mathrm{~m}$ at Eagle Mountain. When the Amargosa River integrated the two basins during the Pleistocene, the change in the stream gradient was relatively subtle. Erosion into the Ash Meadows deposits resulted 
from the integration of the two basins. When the Amargosa River breached the Tecopa Basin and became integrated with Death Valley, massive downcutting exposed tens of meters of palustrine deposits in the Tecopa Basin because of the vast elevation difference between the Tecopa and Death Valley Basins.

Converging alluvial fans, terrace alluvium, and finegrained playa/palustrine deposits have filled the basin since the Pliocene. In the Ash Meadows area at the southern end of the basin, the regional aquifer intersects the surface, which results in the accumulation of paleodischarge deposits (Belcher, 2004). These deposits extend to depths of hundreds of meters, which indicate that the regional aquifer has intersected the surface at this locality for a long time (Taylor and Sweetkind, 2010). Similar paleodischarge or palustrine deposits are exposed to the south, in the Tecopa and Shoshone areas. Playas are still active in the Amargosa Desert, including Franklin playa near Crystal.

\section{Estimated Rates of Basin Aggradation in the Vicinity of US Ecology}

Rates of alluvial aggradation in the vicinity of ADRS have been determined by dated borehole sediments (table 1, fig. 3). Fine-grained alluvium was dated by Thermoluminescence (TL) and Infrared Stimulated Luminescence (IRSL or Optically Stimulated Luminescence (OSL) on feldspar). Dating deposits by TL and IRSL is dependent on the assumption that the deposits were exposed to the sun long enough to "zero" the traps used to date the sediments. Sediment traps measured for TL are reset by exposure to the sun much more slowly that those measured for IRSL. TL samples, therefore, have a higher likelihood of not being completely reset, and may preserve an older signature or sediment age. An older age will result in a slower aggradation rate than a younger age at the same depth. In the borehole data from ADRS, the sediment

Table 1. Ages of deposits dated in the vicinity of US Ecology.

[Thermoluminescence (TL) and Infrared Stimulated Luminescence (IRSL) ages were obtained from boreholes UZB-1 and UZB-2, and modern eolian, and fluvial samples at the Amargosa Desert Research Site. A volcanic ash in borehole AFPL-2 and a basalt sample intersected in NC-EWDP-32P also were dated. Subsamples or splits of the same sample are labeled a, b or c. m, meters]

\begin{tabular}{|c|c|c|c|c|c|}
\hline Borehole or sample & Top (m) & Bottom (m) & Ash age & TL age & IRSL age \\
\hline Modern eolian & 0 & 0.1 & & $6,740 \pm 220$ & $3,160 \pm 110$ \\
\hline Modern fluvial-1 & 0 & 0.1 & & $5,020 \pm 240$ & $1,350 \pm 90$ \\
\hline UZB-1.1a & 5.7 & 5.78 & & $39,200 \pm 3,100$ & $23,600 \pm 1,100$ \\
\hline UZB-1.1b & 5.7 & 5.78 & & $29,900 \pm 3,500$ & \\
\hline UZB-1.2b & 8.93 & 9.01 & & $35,400 \pm 3,500$ & \\
\hline UZB-1.3a & 17.83 & 17.91 & & $37,700 \pm 1,400$ & $38,300 \pm 1,200$ \\
\hline UZB-1.3c & 17.83 & 17.91 & & $25,400 \pm 1,800$ & $36,800 \pm 2,000$ \\
\hline UZB-2.1a & 36.31 & 36.39 & & $49,500 \pm 5,800$ & $42,900 \pm 4,200$ \\
\hline UZB-2.1b & 36.31 & 36.39 & & & $55,700 \pm 6,400$ \\
\hline UZB-2.3b & 60 & 60.08 & & $55,700 \pm 11,700$ & $65,700 \pm 4,100$ \\
\hline UZB-2.3a & 60 & 60.08 & & $56,800 \pm 2,600$ & \\
\hline AFPL-2 & 13.5 & 14 & 640,000 & & \\
\hline NC-EWDP-32P & 120.4 & 149.96 & $3,865,000 \pm 125,000$ & & \\
\hline
\end{tabular}


samples dated by IRSL tended to be younger than the ages determined by TL only for the samples less than $30 \mathrm{Ka}$. As a result, in these samples, higher aggradation rates are estimated from the IRSL samples than the TL samples (fig. 3).

Buried volcanic units, found in boreholes in the vicinity of USE, also were dated. One volcanic ash intersected between 13.5 and $14.0 \mathrm{~m}$ in AFPL-2 (fig. 1), southeast of USE, was correlated by geochemical analyses to the Lava Creek B ash (Sarna-Wojcicki, written commun., 2000). A basalt, intersected near Lathrop Wells between 120 and $150 \mathrm{~m}$ (Nye County NC-32P), was dated by K-Ar methods. The 640-Ka age of the Lava Creek B ash is well documented (Izett and others, 1992; Sarna-Wojcicki and others, 1987), and the 3.74-3.99 m.y. age for the buried basalt from borehole NC-EWDP-32P (R. Spengler, written commun., 2005), south of Lathrop Wells Cinder Cone, is within the expected range of regional basalts.

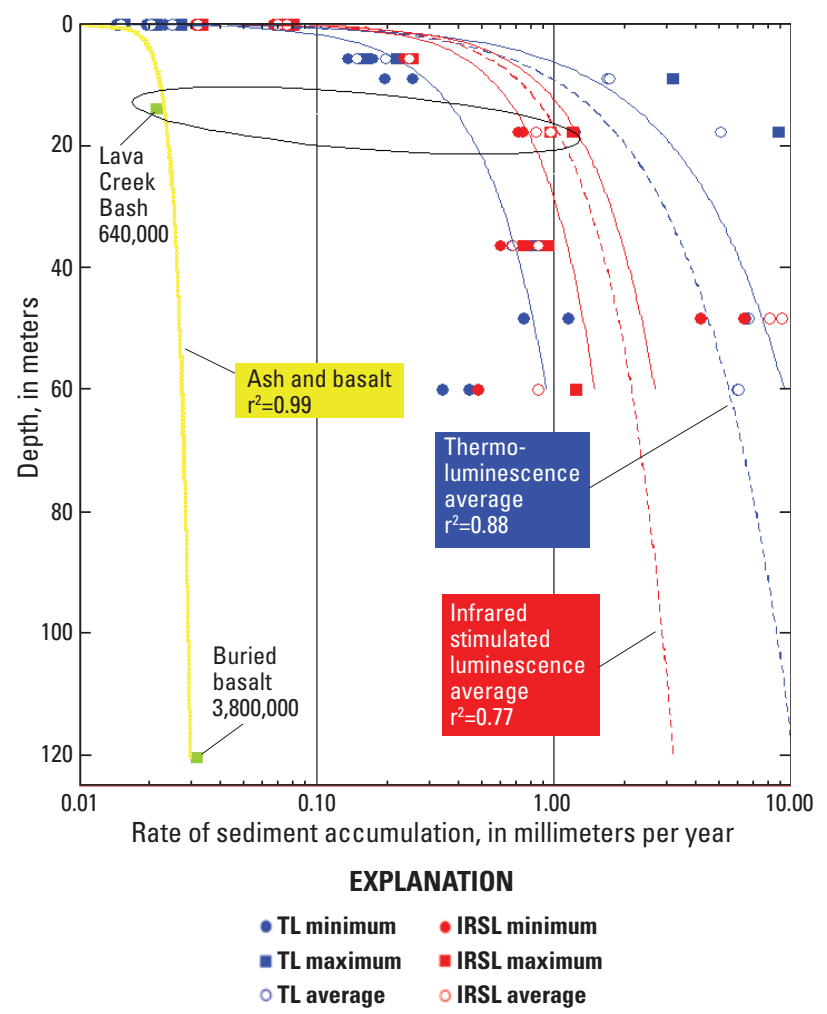

Figure 3. Rates of sediment accumulation in comparison to depth of sample. Thermoluminescence data are blue and Infrared Stimulated Luminescence data are red. The maximum and minimum is the possible range determined by the $+/-$ of the age estimate. Closed circles are the minimum, squares are the maximum, and open circles are the average rate. Solid lines are the best fit curves for the maximum and minimum data, and the dashed line is the best fit average rate. Long-term average rates, based on the ages of the ash and basalt, reflect a relatively constant steady rate of aggradation. Greater sensitivity can be determined from the younger Thermoluminescence and Infrared Stimulated Luminescence ages in the top 60 meters. Average rates of accumulation do not always fall as the midpoint between the maximum and minimum rates because of the errors bounding any given age (see Appendix 1).
Compounded by the inherent assumptions in dating deposits by TL and IRSL, it is important to remember the complexity of an alluvial/fluvial system. Long-term accumulation is the result of aggradation and erosion, controlled by both climatic effect and the tectonic processes. Episodes of aggradation can be followed by periods of erosion or incision, reducing a sequence of deposits to little or nothing. In arid alluvial environments, maximum aggradation occurs when precipitation is high and vegetation is low and erosion is typically the result of changes in the base level of the alluvial drainage. In this paper I set some of these problems aside, accept these known problems, and attempt to look at long-term aggradation rates using the buried dated deposits.

The Lava Creek B Ash was deposited across the Western U.S. when the continental glaciers were retreating and the cool, dry climate was changing to a warmer and wetter, interpluvial climate (Dethier, 2001). In the arid Southwest, these conditions are conducive to aggradation because the decrease in the vegetation and increase in precipitation destabilizes hillslopes and sediment is available for alluviation (Bull, 1991). Slope deposits are bound less by plant roots, and material is made available for transport. Sequences of alluviation are repeated throughout the Pleistocene (10 ka to 2.6 m.y.) as the continental climate fluctuated between cool, dry pluvials and warm, wet interpluvials. These stacked sequences are observed at USE. Long-term aggradation rates determined by the ash $(640 \mathrm{ka})$ and basalt $(3,865 \mathrm{ka})$ samples indicate a rate of accumulation between 0.02 and $0.03 \mathrm{~mm} / \mathrm{yr}(2-3 \mathrm{~cm} / \mathrm{ka})$. The details of single climatic changes are lost over time. Long-term rates are dramatically different than the record of alluviation during the last $70 \mathrm{ka}$ that was suggested by the TL and IRSL dates.

In the vicinity of USE, I have the unusual luxury of a large number of sediment dates over a relatively shallow sequence - the top $60 \mathrm{~m}$ of deposition (table 1). The samples include modern eolian, fine-grained fluvial deposits and subsurface alluvial samples collected from USGS boreholes UZB-1, 2, and 3. These boreholes are located in the southwest corner of USE, in and adjacent to ADRS. Borehole samples were dated at about 10-m intervals, and each sample was split into two subsamples for analyses. The splits were all dated. Older deposits are deeper, and the ages indicate generally that the sediment accumulated at a relatively constant rate (fig. 4). By determining the thickness of the material accumulated over time and the age of the deposit, rates of accumulation can be calculated (fig. 5).

Modern alluvium, sampled from the active channel, was greater than 7,000 years old when dated by TL, and about half that age when dated by IRSL. Both TL and IRSL dating methods assume samples exposed to prolonged direct sunlight will be "zeroed" and the dating clock reset once the sediments are exposed at the surface. Fine-grained deposits in active alluvial systems, however, do not appear to remain in direct exposure to sunlight long enough to remove the old luminescent signature. Thus, buried deposits may be younger than analyzed, which suggests faster rates of accumulation than calculated here. 


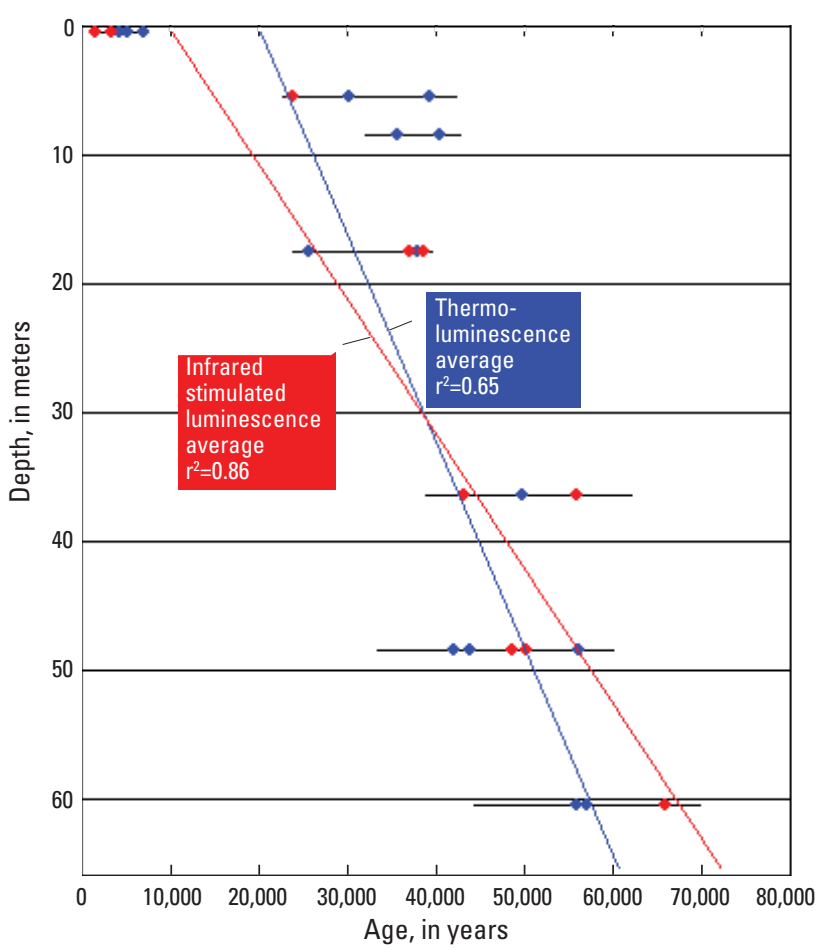

EXPLANATION

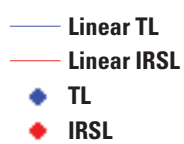

Figure 4. Sediment age in comparison to depth of sample. Blue circles are the Thermoluminescence data, and red circles are the Infrared Stimulated Luminescence data. Bars represent the range of ages for all samples at that depth. The relation of the age to depth is expressed by the linear regression ( $r^{2}$ value) from both dating techniques. The $r^{2}$ value for the Infrared Stimulated Luminescence samples is significantly higher than the $r^{2}$ value for the Thermoluminescence samples, indicating a more reliable technique.

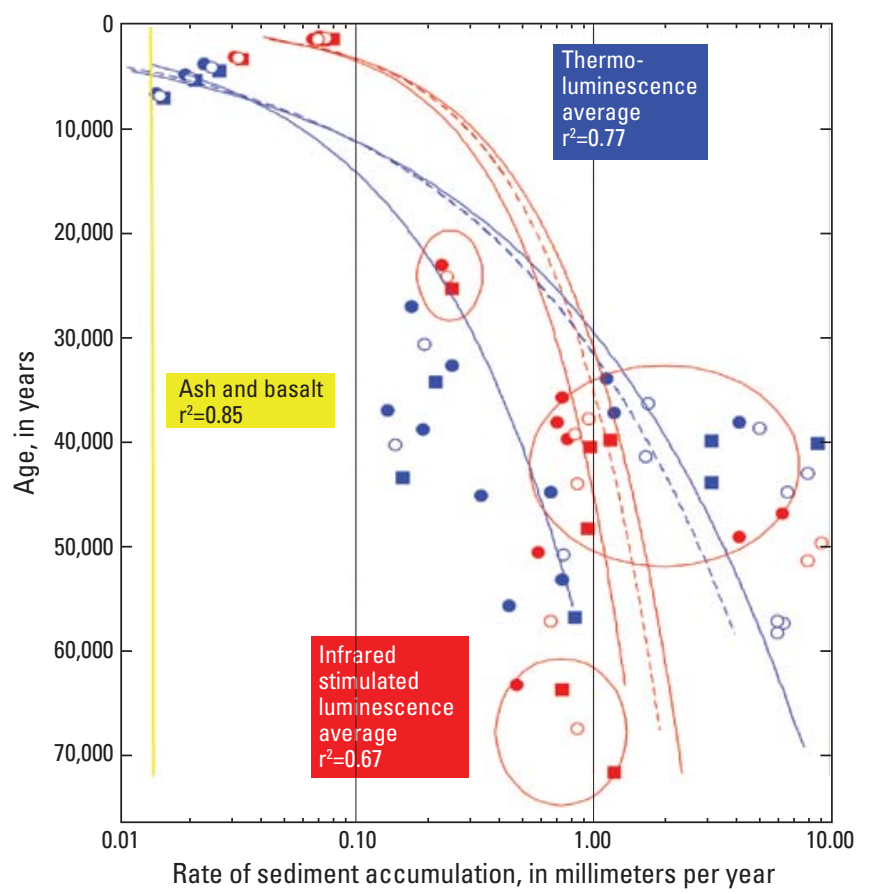

\section{EXPLANATION}

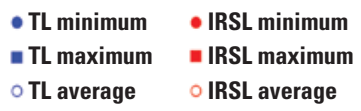

Range of rates of accumulation, excluding modern wash samples

$$
\begin{aligned}
& \text { Thermoluminescence } \quad 0.9-6.9 \text { (average }=3.9 \text { millimeters } / \text { year) } \\
& \begin{array}{c}
\text { Infrared stimulated } \\
\text { luminescence }
\end{array} \\
& 1.7-3.77 \text { (average }=2.7 \text { millimeters } / \text { year) }
\end{aligned}
$$$$
\text { ash }+ \text { basalt } \quad 0.02-0.03 \text { (average }=0.025 \text { millimeters } / \text { year) }
$$

Figure 5. Rates of sediment accumulation in comparison to age of sample. Thermoluminescence data are blue and Infrared Stimulated Luminescence data are red. The maximum and minimum delineate the possible range determined by the $+/-$ of the age estimate. Closed circles are the minimum, squares are the maximum, and open circles are the average rate. Solid lines are the best fit curves for the maximum and minimum data, and the dashed line is the best fit average rate. Infrared Stimulated Luminescence data tend to cluster around 20,000 , 36,000 and 65,000 years. 
Sample ages for the borehole sediments varied from 5 to $60 \mathrm{ka}$. Excluding the modern wash samples, average rates of accumulation based on the TL method vary from 0.9 to $6.9 \mathrm{~mm} / \mathrm{yr}$ (average $=3.9 \mathrm{~mm} / \mathrm{yr}$ ) and on the IRSL method from 1.7 to $3.7 \mathrm{~mm} / \mathrm{yr}$ (average $=2.7 \mathrm{~mm} / \mathrm{yr}$ ). These values are much greater than the long-term average $(0.025 \mathrm{~mm} / \mathrm{yr})$ based on the ash and basalt samples (0.64-3.8 m.y.).

Detailed regional climatic records of the time period between 4.5 and $500 \mathrm{ka}$ (Winograd and others, 1992 and 2006) indicate that maximum cool-dry periods occurred at $\approx 75$ and $\approx 34$ ka followed by steady warming. This record also indicates a relatively abrupt warming trend at $\approx 17 \mathrm{ka}$. These climate changes, regionally recorded, should result in periods when material is available for transport and increased rates of accumulation occur - climatic transitions from relatively cooldry climates to warm-wet periods. Sediment ages from the borehole data tend to cluster around 20,35-45 and 60-70 ka (fig. 5) indicating periods of sediment accumulation.

Borehole sediments of similar age display a wide range of accumulation rates (fig. 5), although samples dated by IRSL tend to have less variability. At about $20 \mathrm{ka}$, between 35 and $45 \mathrm{ka}$, and between 60 and $70 \mathrm{ka}$ there are clusters of samples that may represent sediment accumulation associated with climate warming at $\approx 17, \approx 34$, and $\approx 75 \mathrm{ka}$.

The large discrepancy between the long-term rate and the rates in sediments less than 70 ka may be explained in several ways. The rates of sediment accumulation are different in the two data sets (fig. 3). At a depth of $15 \pm 2 \mathrm{~m}$, the aggradation rate at the ash site is $0.02 \mathrm{~mm} / \mathrm{yr}$. At a similar depth at the ADRS site, the aggradation rate is $1 \mathrm{~mm} / \mathrm{yr}$ as determined by IRSL. The sediment source for the two areas is different-one being from the Amargosa River (borehole data) and the other from Fortymile Wash (ash and basalt data). ADRS is adjacent to a once-active tectonic range front at Bare Mountain, rather than in the center of the basin. Sediment is being introduced from the migrating Amargosa River as well as shedding off the range front fans. Fortymile Wash may not be a good analog to ADRS. A second possibility is that the TL and IRSL ages may be much too young resulting in too rapid aggradation rates. However, it is more likely that the ages are too old, rather than too young, because sediment traps dated by luminescence may not be completely emptied by sunlight in alluvial system. Finally, long-term rates tend to reflect gains and losses in the depositional history while short-term rates record extremes. Sediment is removed as changes occur in the basin evolution, including stream capture. These erosional periods are reflected in the long-term rate and may or may not be part of the shorter term record.

Intuitively we know that rates have decreased as the basin has become more tectonically quiescent (Fridrich and others, 1999). This also can be verified by solving the rate curve for greater depths where aggradation rates approach $20 \mathrm{~mm} / \mathrm{yr}$ at the contact between the Paleozoic basement and the Tertiary basin fill.

\section{Three-Dimensional Lithologic Model of the Subsurface Geology}

Data were compiled from 57 boreholes representing nearly 2,000 depth intervals or records (table 2, Appendix 1). Ten other boreholes were added to the model that were located outside the USE model boundary. Boreholes ranged in depth from 10 to $200 \mathrm{~m}$. The average depth of the boreholes was $85 \mathrm{~m}$, with the majority falling between 90 and $135 \mathrm{~m}$ (fig. 6). The data varied in quality from detailed lithologic descriptions collected by an onsite geologist during the time of the drilling, to brief summaries at 10 -foot increments. The most common description varies from between one and ten words that describe a change recognized by the driller as a different unit is penetrated - fine grained to coarse grained and presence or absence of large rocks, poorly consolidated to well indurated, rock type or abrupt color changes, are good examples.

If the physical characteristics of the surficial geology exposed at the surface are understood, these geologic mapping criteria can be used to simplify the subsurface geology. Alluvial units can be distinguished from fine-grained playa/ palustrine deposits. Proximal coarse-grained deposits can be distinguished from distal deposits and interbedding can be recognized. After the drillers' descriptions were simplifed to 11 lithologic units, they were correlated to stratigraphic units consistent with the geologic mapping (table 3).

The lithologic units, derived from the drillers' descriptions, were used to construct a lithology model using RockWorks 14 (RockWare, Inc., Denver, Colo.). The threedimensional lithology solid model was created from the borehole data using a solid modeling method within RockWorks 14 called horizontal lithoblending. This is a cell-based modeling approach where solid-model cell nodes sequentially are assigned properties by looking outward horizontally from each borehole in search circles of ever-increasing diameter. Cell dimensions for the modeling were $10 \mathrm{~m}$ in the horizontal dimensions and $5 \mathrm{~m}$ in the vertical dimension. The algorithm assigns the lithology values from the borehole data in each vertical interval to cells immediately surrounding each borehole. Then the interpolation moves out by a cell, and assigns the next "circle" of cells a lithology value for each vertical interval. The interpolation continues in this manner until the program encounters a cell that is already assigned a lithology (presumably interpolating towards it from an adjacent borehole), in which case it skips the node assignment step. The interpolated data in the resulting solid model have the appearance of stratigraphic units, with aspect ratios that emphasize the horizontal dimension over the vertical dimension.

In order to produce smoothly varying facies trends, the three-dimensional interpreted facies solid model was created using an inverse-distance algorithm. In this method, the facies value of each cell is assigned based on the weighted average of neighboring data points, and the value of each data point is weighted according to the inverse of its distance from the cell. Distant control points have less effect on the assignment of the facies value to each cell. During the interpolation a weighting 
Table 2. Summary of borehole data.

[Ten different companies drilled exploratory and/or monitory dill holes at the USE site. The first column has numbers 1 through 10 to indicate the different companies. m, meter]

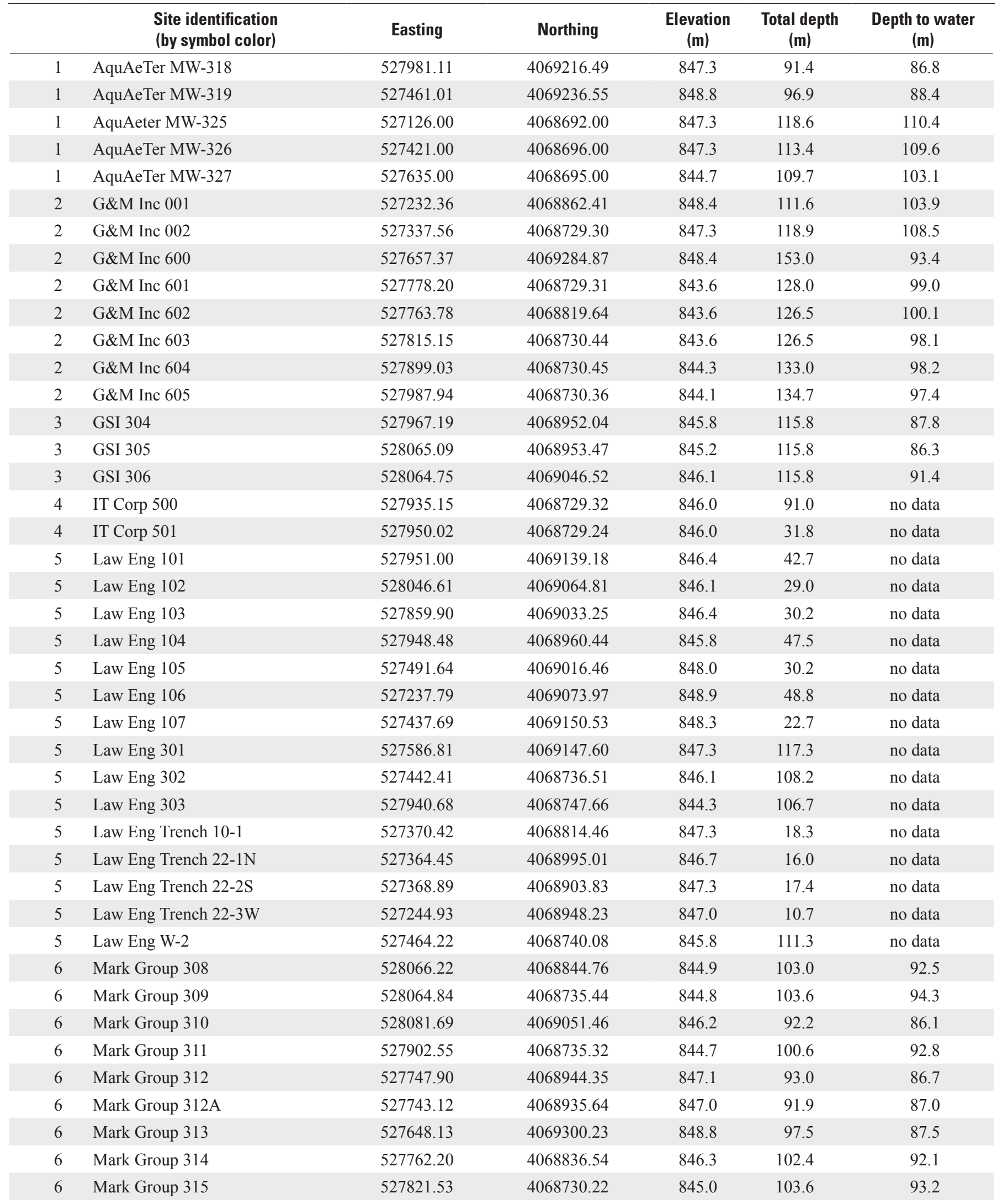


Table 2. Summary of borehole data.-Continued

[Ten different companies drilled exploratory and/or monitory dill holes at the USE site. The first column has numbers 1 through 10 to indicate the different companies. m, meter]

\begin{tabular}{|c|c|c|c|c|c|c|}
\hline & $\begin{array}{l}\text { Site identification } \\
\text { (by symbol color) }\end{array}$ & Easting & Northing & $\begin{array}{l}\text { Elevation } \\
(\mathrm{m})\end{array}$ & $\begin{array}{l}\text { Total depth } \\
\text { (m) }\end{array}$ & $\begin{array}{c}\text { Depth to water } \\
\text { (m) }\end{array}$ \\
\hline 6 & Mark Group 316 & 528070.06 & 4068934.46 & 845.9 & 94.5 & 88.2 \\
\hline 6 & Mark Group 317 & 527983.41 & 4068735.80 & 844.7 & 103.6 & 93.4 \\
\hline 6 & Mark Group 400 & 527750.41 & 4068929.22 & 846.6 & 163.7 & 86.3 \\
\hline 6 & Mark Group 401 & 528083.05 & 4068920.13 & 845.2 & 128.0 & 87.5 \\
\hline 6 & Mark Group 402 & 527967.13 & 4069176.07 & 846.9 & 49.8 & no data \\
\hline 6 & Mark Group 402B & 527972.60 & 4069176.42 & 846.9 & 11.4 & no data \\
\hline 6 & Mark Group 402C & 527976.51 & 4069175.77 & 847.2 & 132.9 & 86.0 \\
\hline 6 & Mark Group 403 & 527952.04 & 4068729.84 & 843.9 & 200.6 & 91.7 \\
\hline 7 & Perc Est AFCA1 & 542415.00 & 4046485.00 & 731.0 & 14.5 & no data \\
\hline 7 & Perc Est AFCA2 & 542412.00 & 4046485.00 & 731.0 & 12.0 & no data \\
\hline 7 & Perc Est AFCA3 & 542273.00 & 4046225.00 & 736.0 & 14.5 & no data \\
\hline 7 & Perc Est AFCA4 & 542386.00 & 4045260.00 & 728.0 & 10.1 & no data \\
\hline 7 & Perc Est AFCA5 & 541844.00 & 4044830.00 & 734.0 & 10.1 & no data \\
\hline 7 & Perc Est AFPL1 & 545661.00 & 4044432.00 & 724.0 & 14.6 & no data \\
\hline 7 & Perc Est AFPL2 & 545501.00 & 4044236.00 & 715.0 & 16.6 & no data \\
\hline 7 & Perk Est ARAS1 & 528846.00 & 4062684.00 & 807.0 & 46.5 & 14.2 \\
\hline 7 & Perk Est ARRB1 & 521815.00 & 4072299.00 & 886.0 & 48.5 & 14.8 \\
\hline 7 & U.S. Geological Survey No 1 & 527393.77 & 4068697.29 & 844.3 & 175.0 & 99.4 \\
\hline 8 & Site Well 1961 & 527665.65 & 4068947.67 & 847.5 & 175.3 & 96.0 \\
\hline 9 & U.S. Ecology MW-315A & 527826.23 & 4068730.38 & 847.0 & 98.0 & no data \\
\hline 9 & U.S. Ecology MW-323 & 527668.62 & 4068945.01 & 847.0 & 91.0 & no data \\
\hline 10 & U.S. Geological Survey MR3 & 527389.20 & 4068719.60 & 845.8 & 123.4 & 112.5 \\
\hline 10 & U.S. Geological Survey UZB-1 & 527257.93 & 4068633.22 & 846.0 & 48.2 & 44.2 \\
\hline 10 & U.S. Geological Survey UZB-2 & 527256.70 & 4068644.70 & 846.0 & 114.7 & 109.0 \\
\hline 10 & U.S. Geological Survey UZB-3 & 527336.40 & 4068713.20 & 847.3 & 114.5 & 110.0 \\
\hline
\end{tabular}

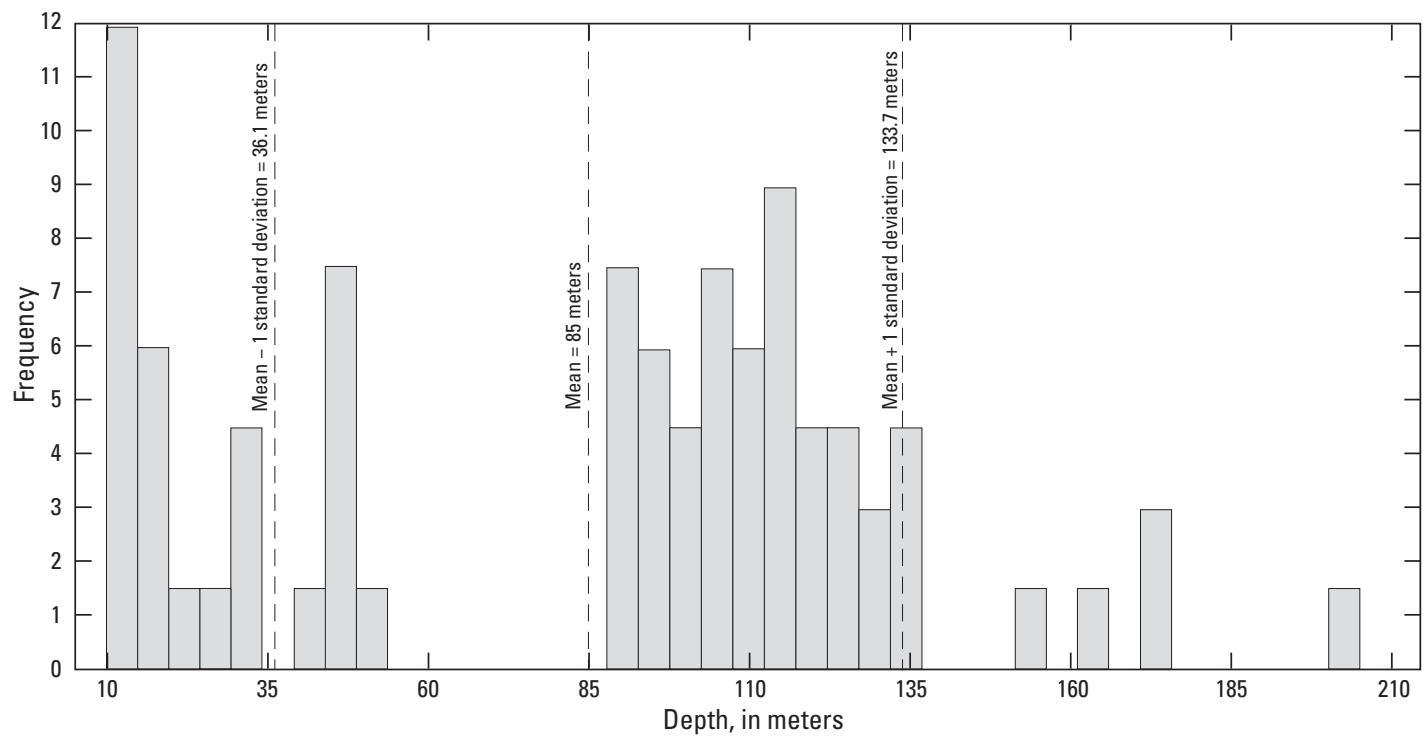

Figure 6. Frequency of borehole depths. The 67 boreholes vary in depth from 10 to 200 meters with an average depth of 85 meters. Most boreholes are between 36- and 133-meters deep. 
Table 3. Simplified drillers' descriptions used to construct the lithologic model.

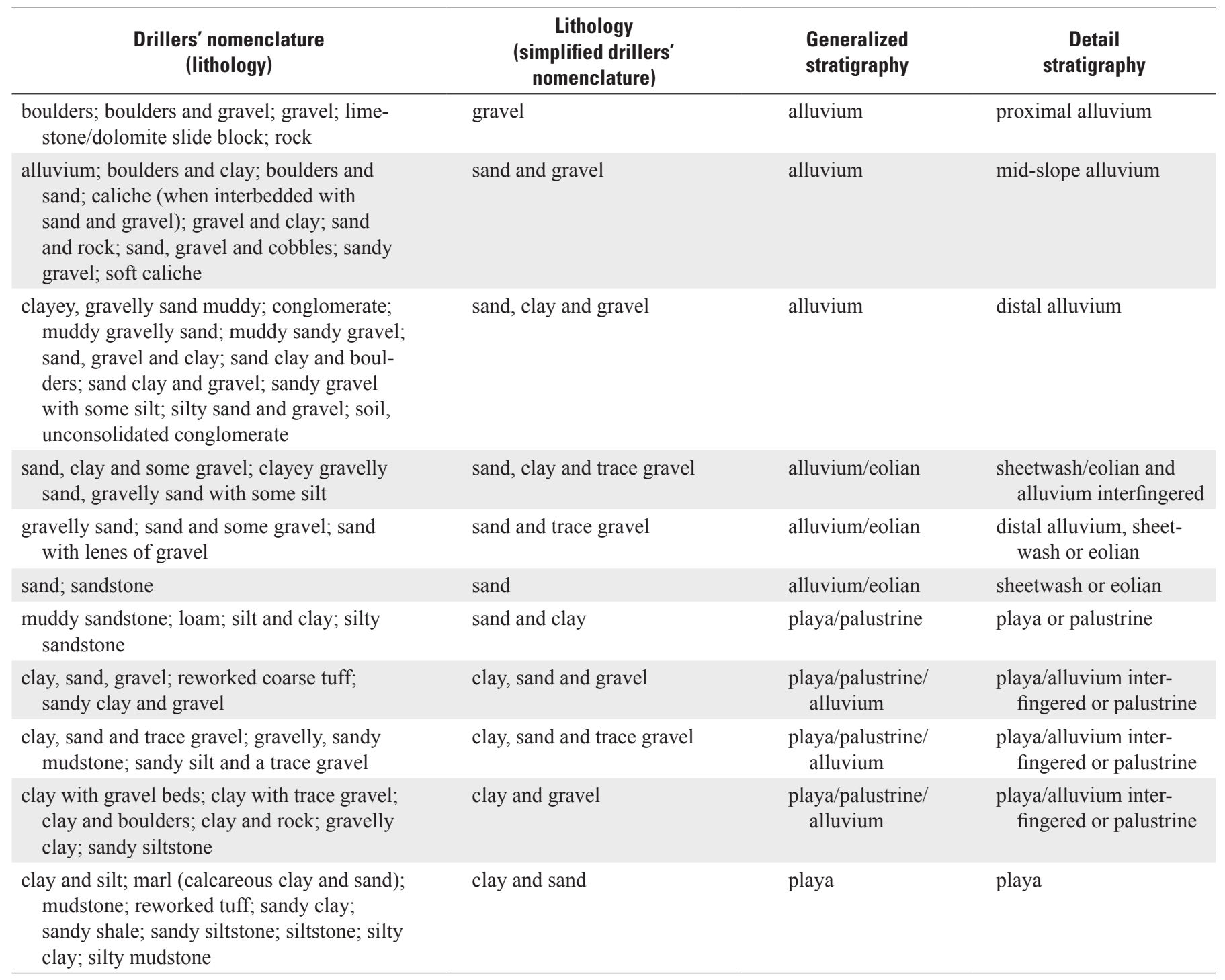


factor of two was used in the inverse distance algorithm. In addition, the interpolation was done using an anisotropic algorithm, where the inverse-distance method searches specifically at the closest point in each 90-degree zone around the cell when assigning the cell value. The borehole data also were declustered to minimize the effects of nonuniformly spaced holes. The model size is $916-\mathrm{m}$ (easting) by 706-m (northing) by $100-\mathrm{m}$ thick and is centered over the 800 by $400 \mathrm{~m}$ USE site. Horizontal layers are 5-m thick. Fence diagrams and isosurfaces, or bubble diagrams, of the individual units were constructed from the lithologic model. These diagrams make it possible to understand the depositional characteristics of the subsurface sediments and to characterize the geologic characteristics that control the local hydrology.

The units intersected at the site vary from coarse-grained gravel, to sand, to clayey sand (figs. 7, 8, and 9). Coarsegrained sand and gravel represent the most common lithologic units intersected. Interbedded with the heterogeneous coarse alluvium are irregular lenses of fine-grained sandy clay with infrequent lenses of coarse-grained gravel. The most striking feature of the subsurface geology is the uniformly stacked fining-upward sequences (fig. 7). Sand and gravel grades upward to a finer sandy or clayey deposit. As observed in the trench wall at USE, this sequence repeats at depth in intervals that range from 5 to $8 \mathrm{~m}$. Each sequence represents a single alluvial deposit. Deposition probably occurred rapidly during a single flood derived from the active axial drainage.

There is no subsurface evidence that playa deposits exist below USE. There are fine-grained intervals, however, they are thin and not continuous and probably record overbank or recessional facies of the stream discharge. These clayey deposits are offset in the fence diagram and were used to locate a splay of the Carrara Fault which is discussed in the "Activity on the Carrara Fault" section of this report. At the USE site, no volcanic units were intersected in any of the boreholes.

The distribution of different lithologic sediment types is shown on the three-dimensional lithologic model (fig. 10). The dominant lithologies in the study area are coarse sand and gravel, sandy, and clayey facies. Coarse sand and gravel are exposed as discrete layers. Interbedded between coarse layers are a combination of sandy and clayey facies, sandy facies are predominant. These stacked sequences also are observable in the trenches at USE (fig. 7).

\section{Comparison of Direct Current Resistivity Profile Data to the Three- Dimensional Lithologic Model}

A detailed direct-current resistivity study was completed in the vicinity of USE (Abraham and Lucius, 2004, Abraham, written commun., 2004). The features resolved in the resistivity data are controlled by moisture, sediment size, and accumulation of soluble salts. These data have been compared at the same locations to profiles that intersect the lithologic model (figs. 11 and 12). The boreholes at USE are not adjacent to the resistivity lines, so the model was built using data in the basin-wide Amargosa data set (Taylor and Sweetkind, 2007). The USE borehole data are between 130 and $500 \mathrm{~m}$ from the projected resistivity lines. As seen in the lithology model (fig. 10) and in trench exposures at USE (fig. 7), the subsurface is characterized by repeated fining-upward sequences between 5- and 8-m thick. Neither the resistivity nor the lithology model, in the vicinity of the resistivity lines, can resolve these stacked sequences, however, these data do display some coarse sedimentological features.

High resistivity values in the top $4 \mathrm{~m}$ (red, $>150 \mathrm{ohm}-\mathrm{m})$ indicate a dry environment of unsaturated soil and sediment. Most water that enters the system is lost to evapotranspiration which results in sediments with little or no moisture at the surface. A small amount of moisture does reach greater depths (Stonestrom and others, 2003). Below the dry surface and above an intermediate resistivity layer (green to yellow, $80-140 \mathrm{ohm}-\mathrm{m}$ ) is a layer with higher water content (blue, $<40 \mathrm{ohm}-\mathrm{m}$ ) (fig. 12). The blue layer probably is composed of coarse gravel found at the base of the fining-upward fluvial sequence. Where abrupt changes in sediment texture occur, water tends to hang up, which results in the precipitation of dissolved salts, primarily calcium carbonate. The lithology model suggests that the wetter zone is found where a depositional unconformity occurs between the coarse sand and gravel and the underlying fining-upward sequence. Moist zones that are enriched in secondary carbonate produce a signature of lower resistivity values. Deposits with higher water content, or lower resistivity, also occur in sediments near the modern water table.

Resistivity lines display, from the surface downward, the dry fine-grained surface, a moist or carbonate-enriched 3-5-m-thick zone of coarse material and, at depth, repeated stacked fining-upward sequences (fig. 12A, line 1). Lines 1 and 3 (figs. $12 \mathrm{~A}$ and $12 \mathrm{C}$ ) are perpendicular to the basin axis, and the highly resistant zones (red pockets), at depth, probably are paleochannels of coarse gravel lenses. The three-dimensional lithology model also indicates that, at this location, these gravel lenses are present. Line 4 (fig. 12D) lacks any evidence of the buried high resistivity layer. Line 4 is parallel to the basis axis and primarily on the elevated ridge of Tertiary gravel. This deposit is capped by a dense soil horizon of cemented secondary carbonate. Moisture that falls on this old surface only infiltrates through fractures in the cemented zone. No intermediate moisture zone is present on line 4, except at the north end, off the elevated ridge, on younger deposits where water infiltrates from the surface. There is corresponding fine-grained material, in this area, in the lithology model. 


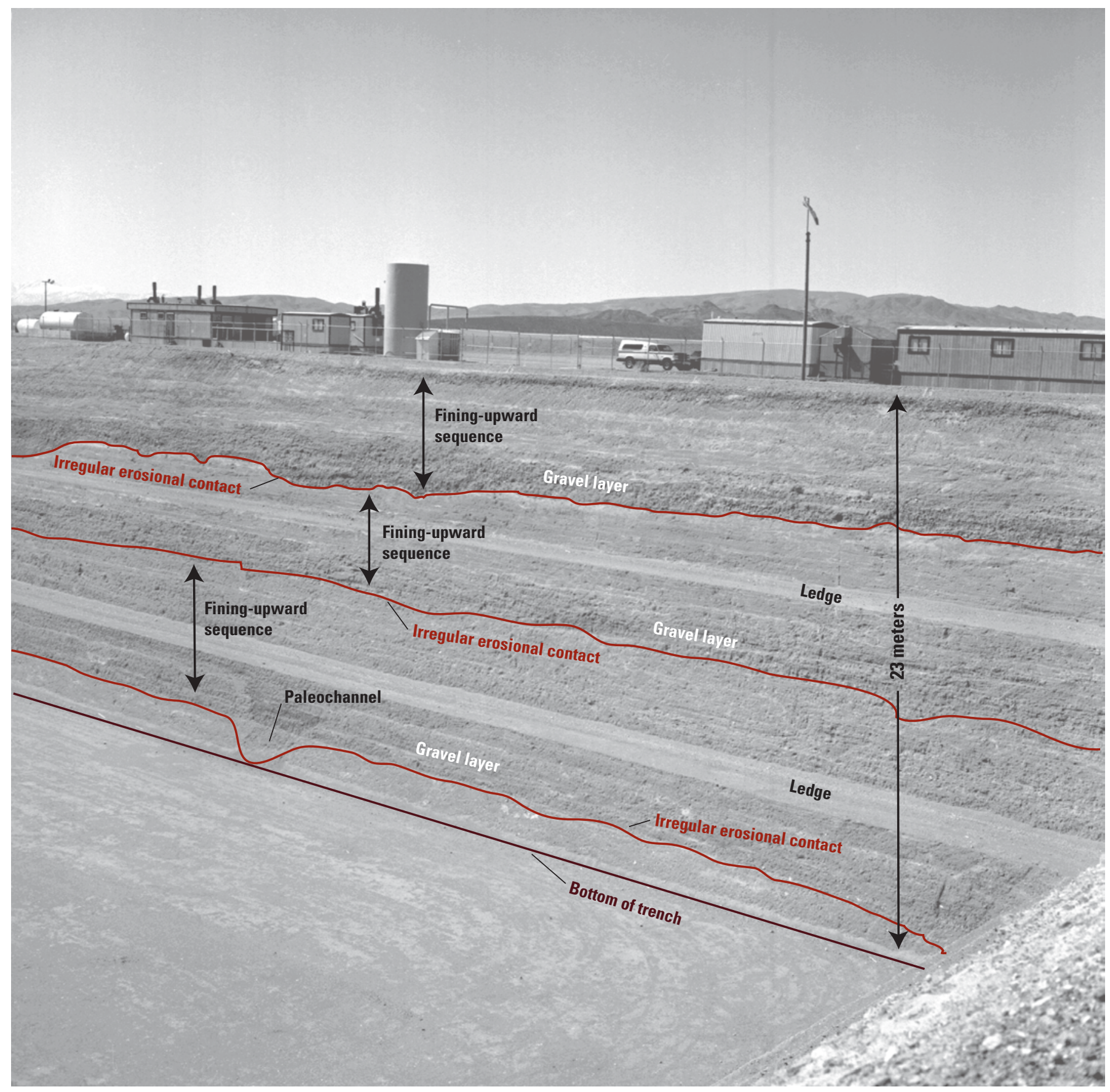

Figure 7. Trench 11 at US Ecology. In the 23 meters exposed in Trench 11 at US Ecology, 3 discrete fining-upward sequences, which vary in thickness from 7 to 8 meters, are exposed as well as a buried paleochannel. Each sequence is characterized by an erosional sand and gravel unit, at the base, that has eroded into the top of the unit below. This abrupt irregular contact is observable in the photograph. Above the sand and gravel are increasing finer units until the depositional unconformity, defined as the base of the next sand and gravel. These sequences are well preserved in the borehole data. 

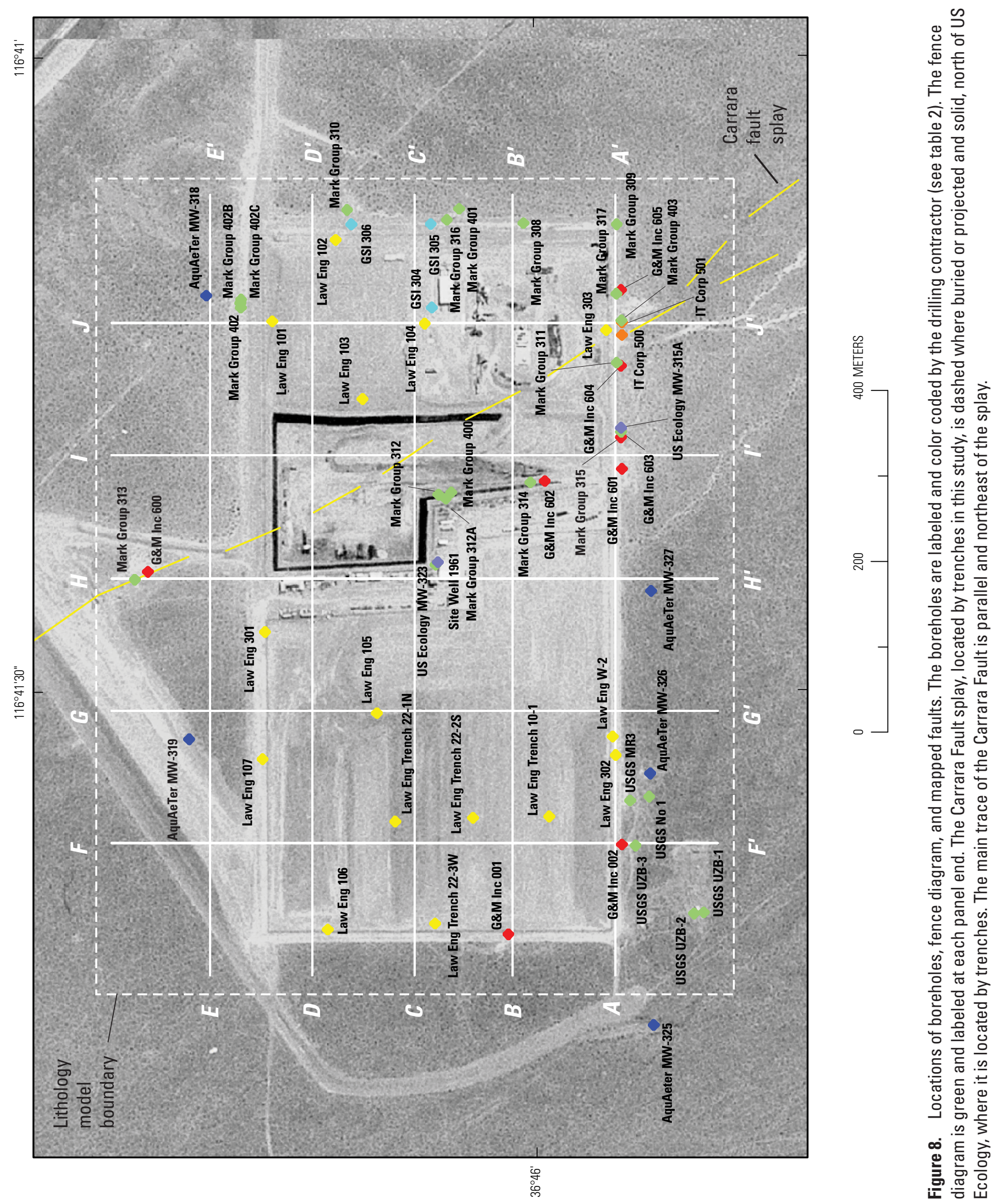


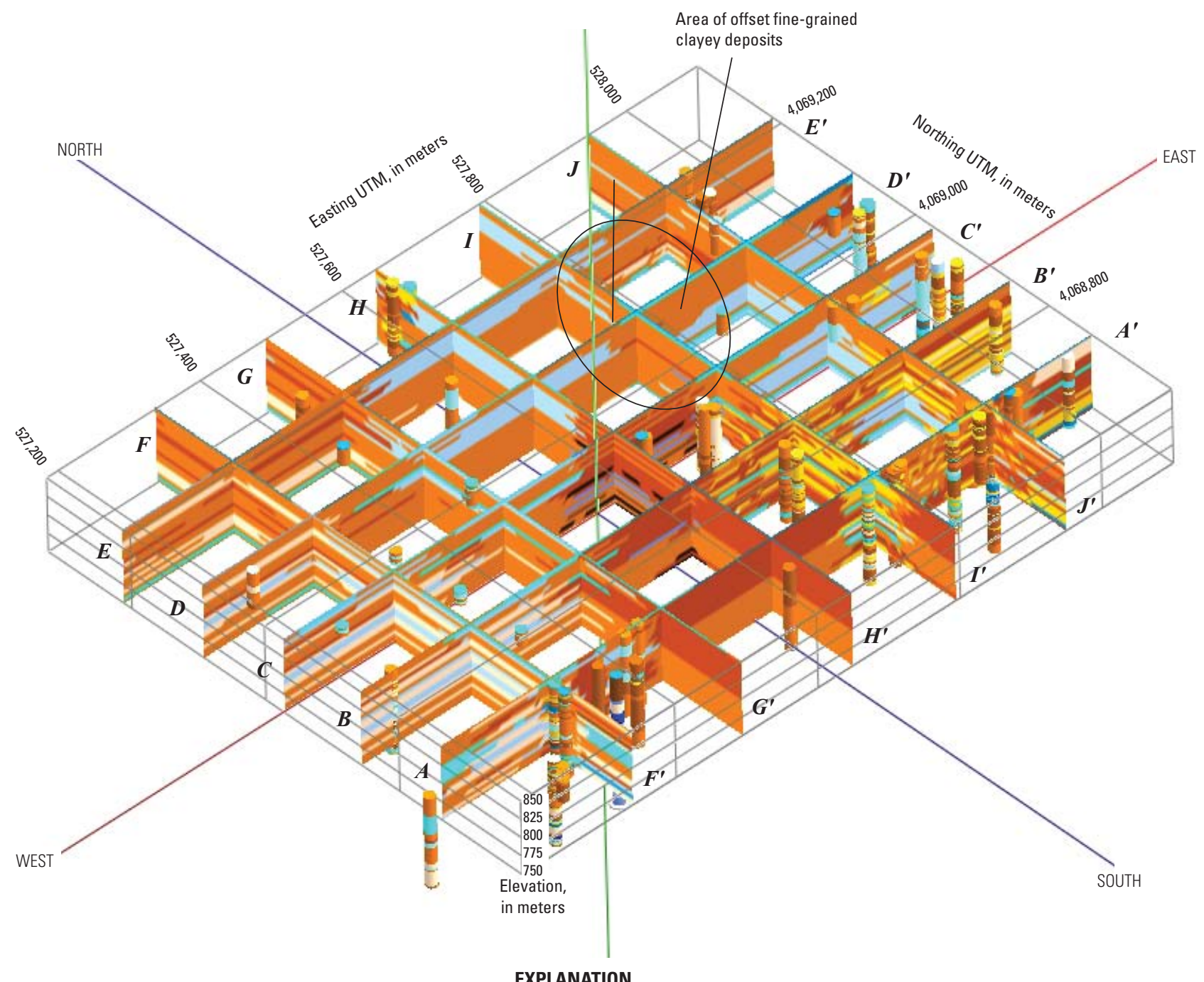

EXPLANATION

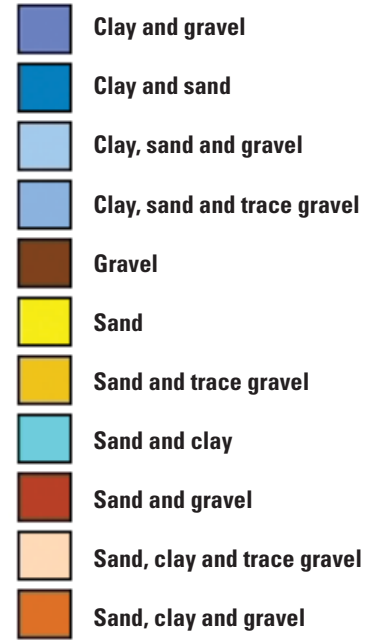

Figure 9. Lithologic fence diagram of the deposits below US Ecology. This model is 100-m thick and displays a thick package of heterogeneous gravel, sand, and clayey sand, which were deposited in an alluvial system. No sequence of playa/palustrine deposits or volcanic rocks were intersected. The lithologic logs are represented as vertical cylinders. The model extrapolates the known data from the logs until it intersects another log that is generating data in a horizontal direction. There is more detail, in the model, where the lithologic logs contain more information. 


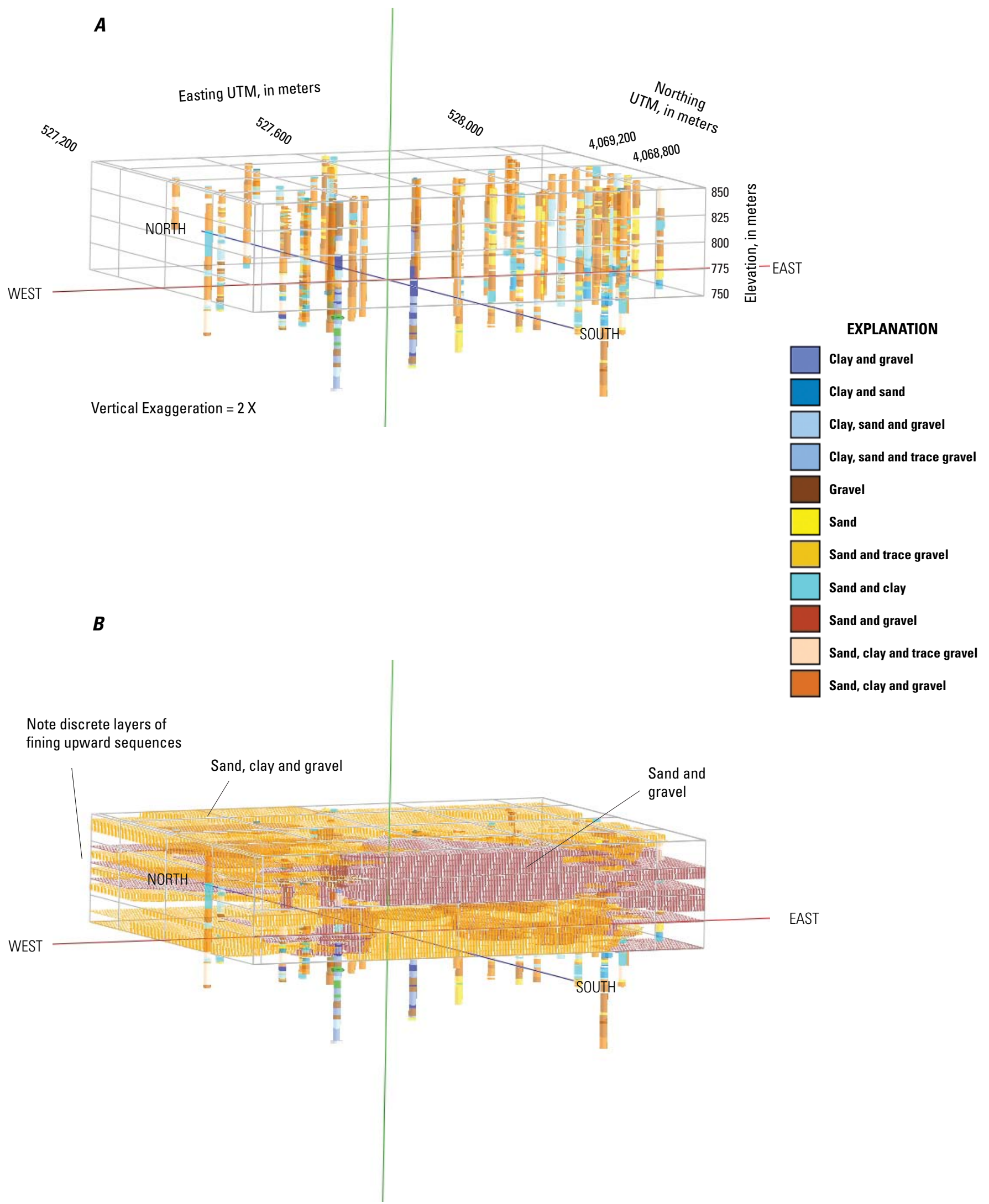

Figure 10. Distribution of sediments in the three-dimensional lithologic model that are predominantly $(A)$ coarse sand and gravel, $(B)$ sandy, $(C)$ clayey lithologies. Each diagram is bound by the three-dimensional lithologic model. Diagram is oriented northeast about 10 degrees above the horizon. 


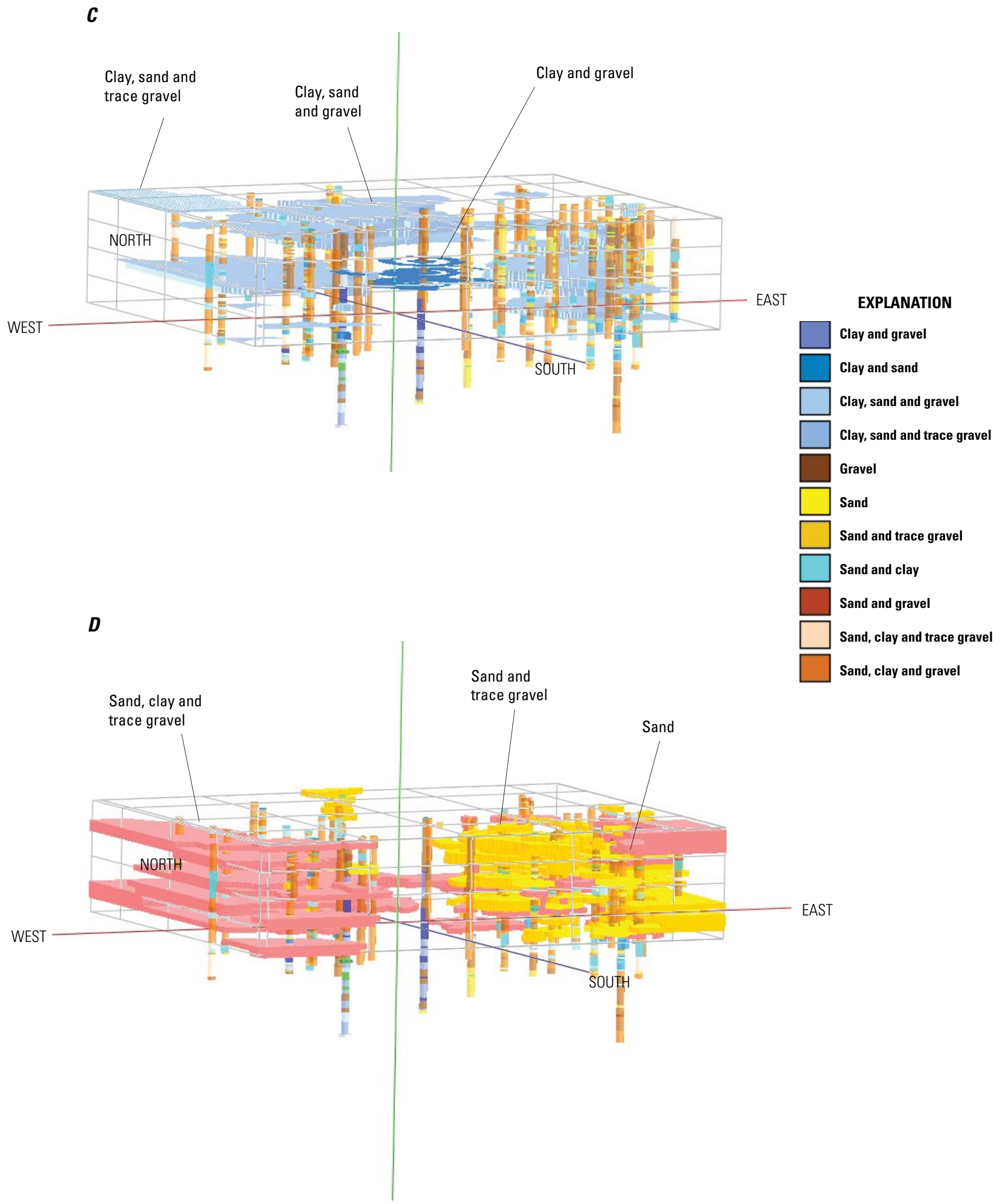

Figure 10. Distribution of sediments in the three-dimensional lithologic model that are predominantly $(A)$ coarse sand and gravel, $(B)$ sandy, $(C)$ clayey lithologies. Each diagram is bound by the three-dimensional lithologic model. Diagram is oriented northeast about 10 degrees above the horizon.-Continued 

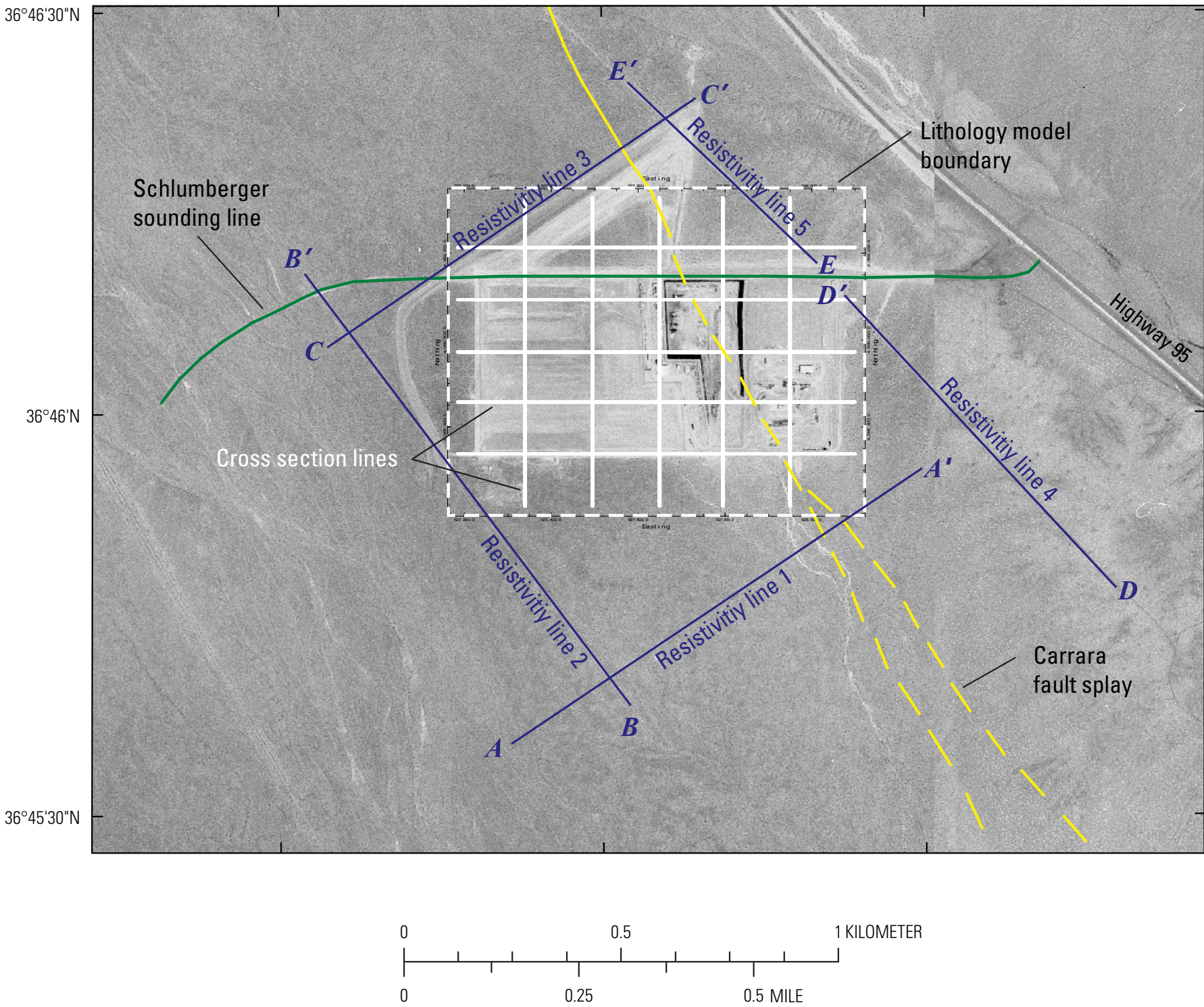

Figure 11. Location of resistivity lines, fence diagram, and model boundary. The resistivity lines are blue, the Schlumberger sounding line is dark green, the cross sections are light green and the model boundary is black. The majority of the resistivity lines fall outside the area where the high density of boreholes exists. 
A. Line 1
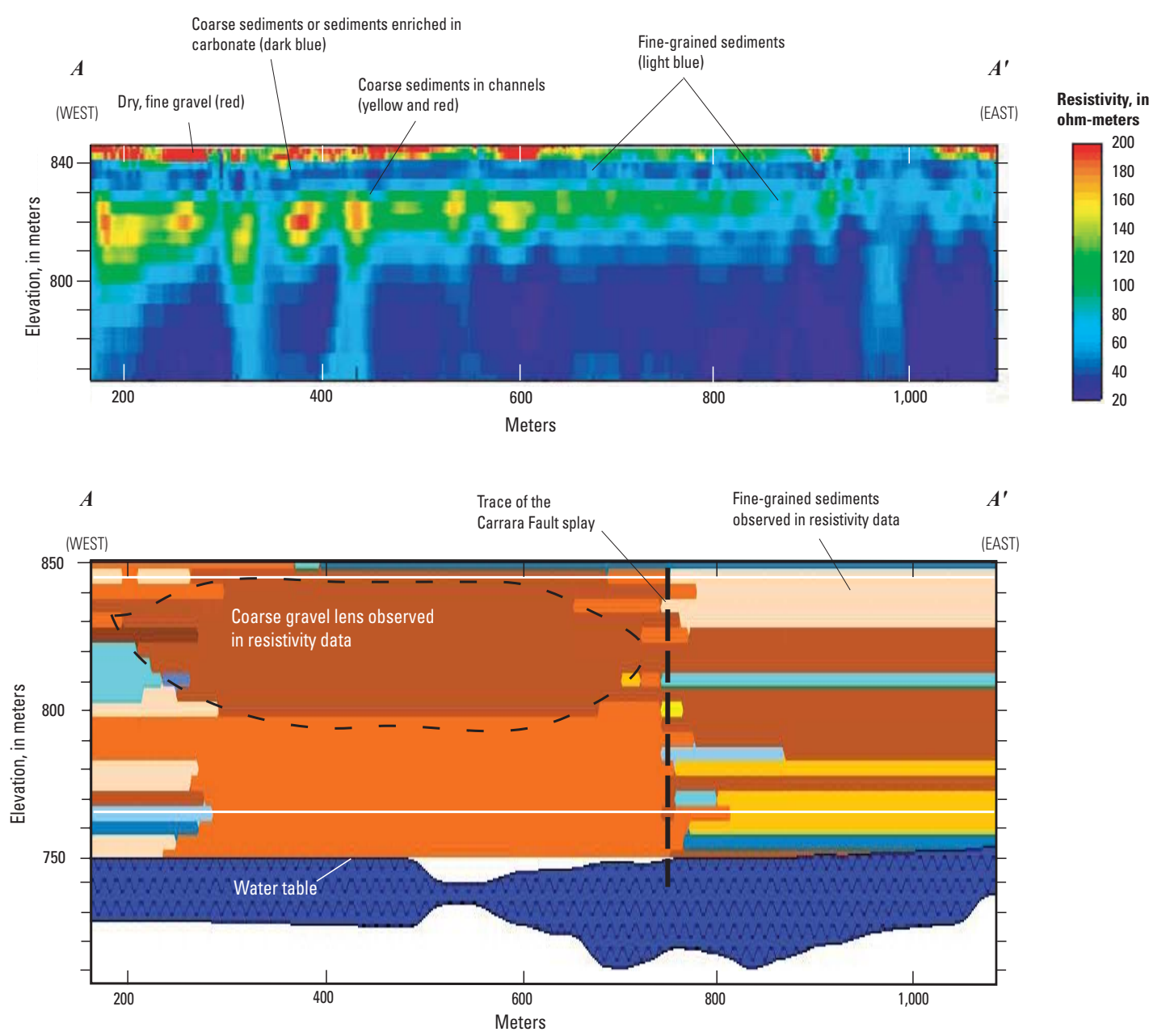

EXPLANATION

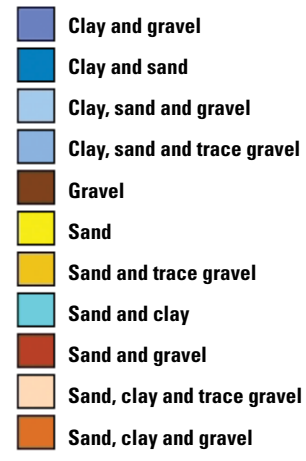

Figure 12. Comparison of the resistivity profiles (top) to the lithology profiles (bottom) along 5 lines surrounding USE. $(A)$ line $1\left(A-A^{\prime}\right) ;(B)$ line $2\left(B-B^{\prime}\right) ;(C)$ line $3\left(C-C^{\prime}\right) ;(D)$ line $4\left(D-D^{\prime}\right)$; and $(E)$ line $5\left(E-E^{\prime}\right)$. Current resistivity data (top) compared to lithologic model (bottom) at the same location. All data are at the same scale, and the area that is in both diagrams is between the two white lines on the lithology diagram. The lithology model is deeper than the resistivity data and includes the top of the water table. The base of the water table is an artifact of drill hole depth. Vertical scales are equal, and resistivity data are above the modern water table. Higher resistivity levels are warm colors (less than $150 \mathrm{ohm}-\mathrm{m}$ ) and indicate dry sediments. Lower resistivity values are cooler colors and indicate wetter sediments, the presence of dissolved soluble salts or fine-grained sand and clay. 


\section{B. Line 2}

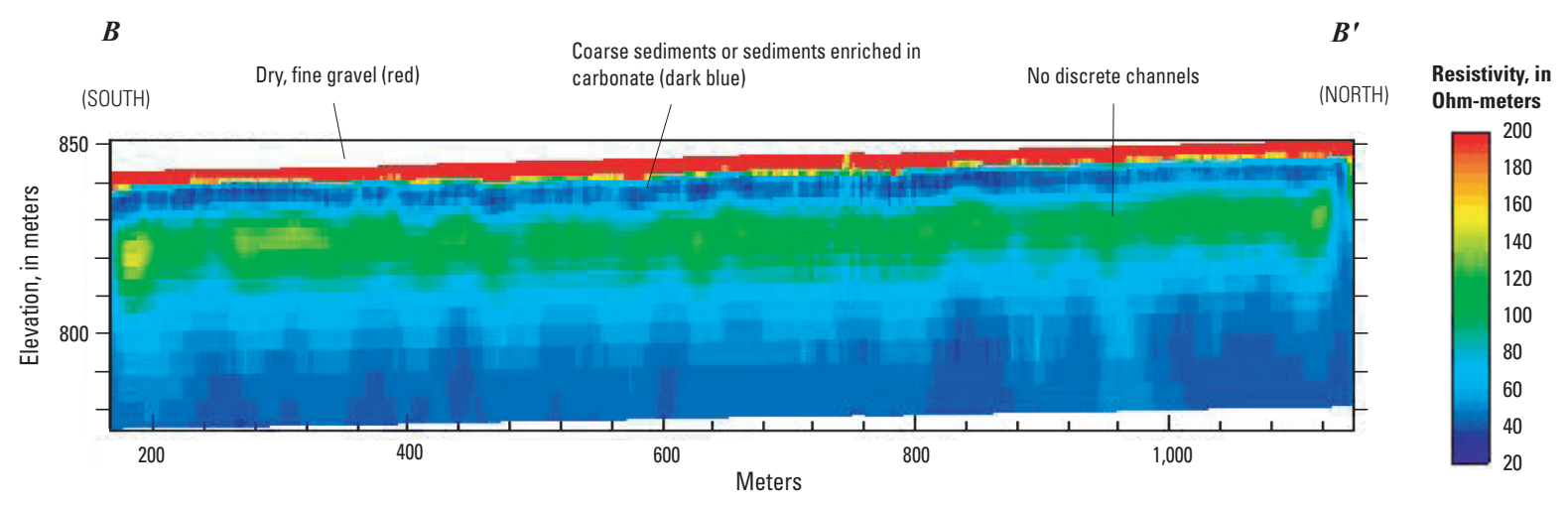

$B$

$B^{\prime}$

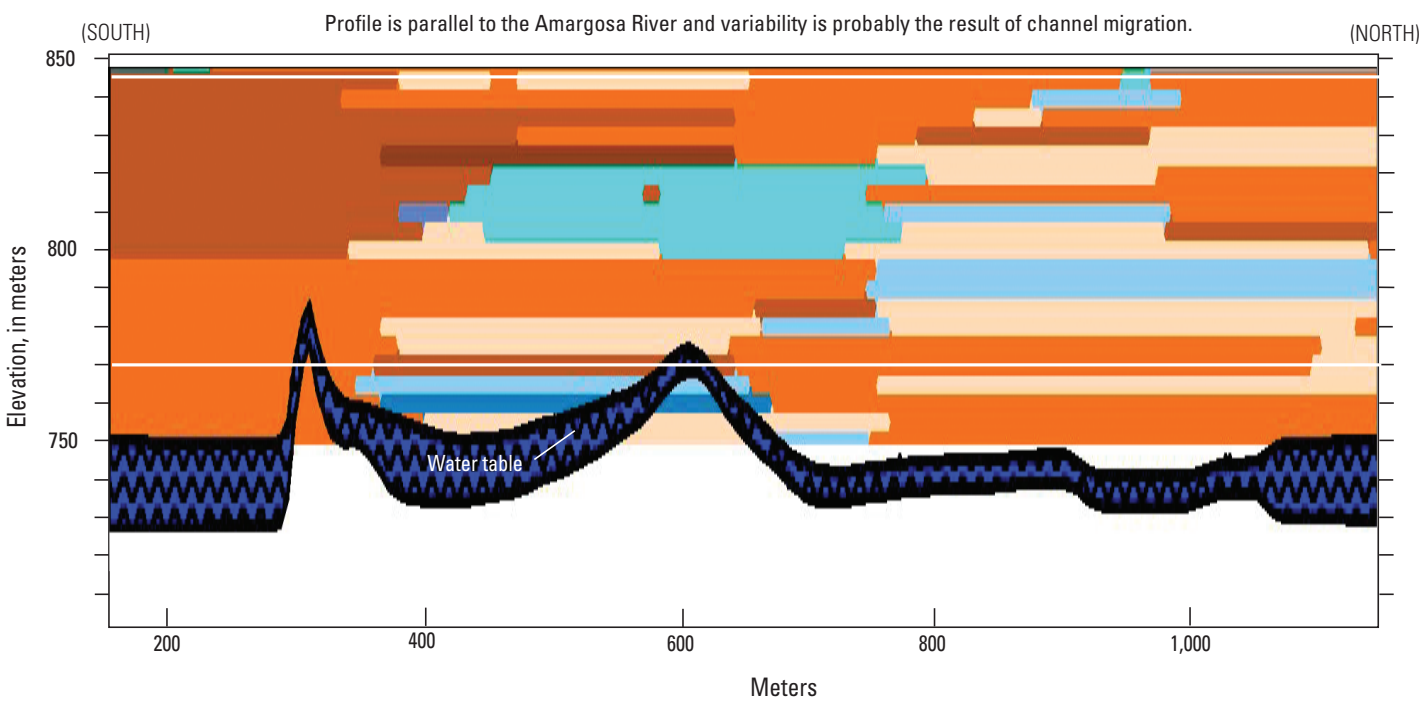

EXPLANATION

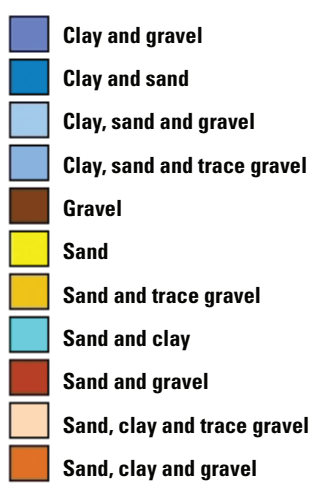

Figure 12. Comparison of the resistivity profiles (top) to the lithology profiles (bottom) along 5 lines surrounding USE. $(A)$ line $1\left(A-A^{\prime}\right) ;(B)$ line $2\left(B-B^{\prime}\right) ;(C)$ line $3\left(C-C^{\prime}\right) ;(D)$ line $4\left(D-D^{\prime}\right)$; and $(E)$ line $5\left(E-E^{\prime}\right)$. Current resistivity data (top) compared to lithologic model (bottom) at the same location. All data are at the same scale, and the area that is in both diagrams is between the two white lines on the lithology diagram. The lithology model is deeper than the resistivity data and includes the top of the water table. The base of the water table is an artifact of drill hole depth. Vertical scales are equal, and resistivity data are above the modern water table. Higher resistivity levels are warm colors (less than $150 \mathrm{ohm}-\mathrm{m}$ ) and indicate dry sediments. Lower resistivity values are cooler colors and indicate wetter sediments, the presence of dissolved soluble salts or fine-grained sand and clay._- Continued 


\section{Line 3}
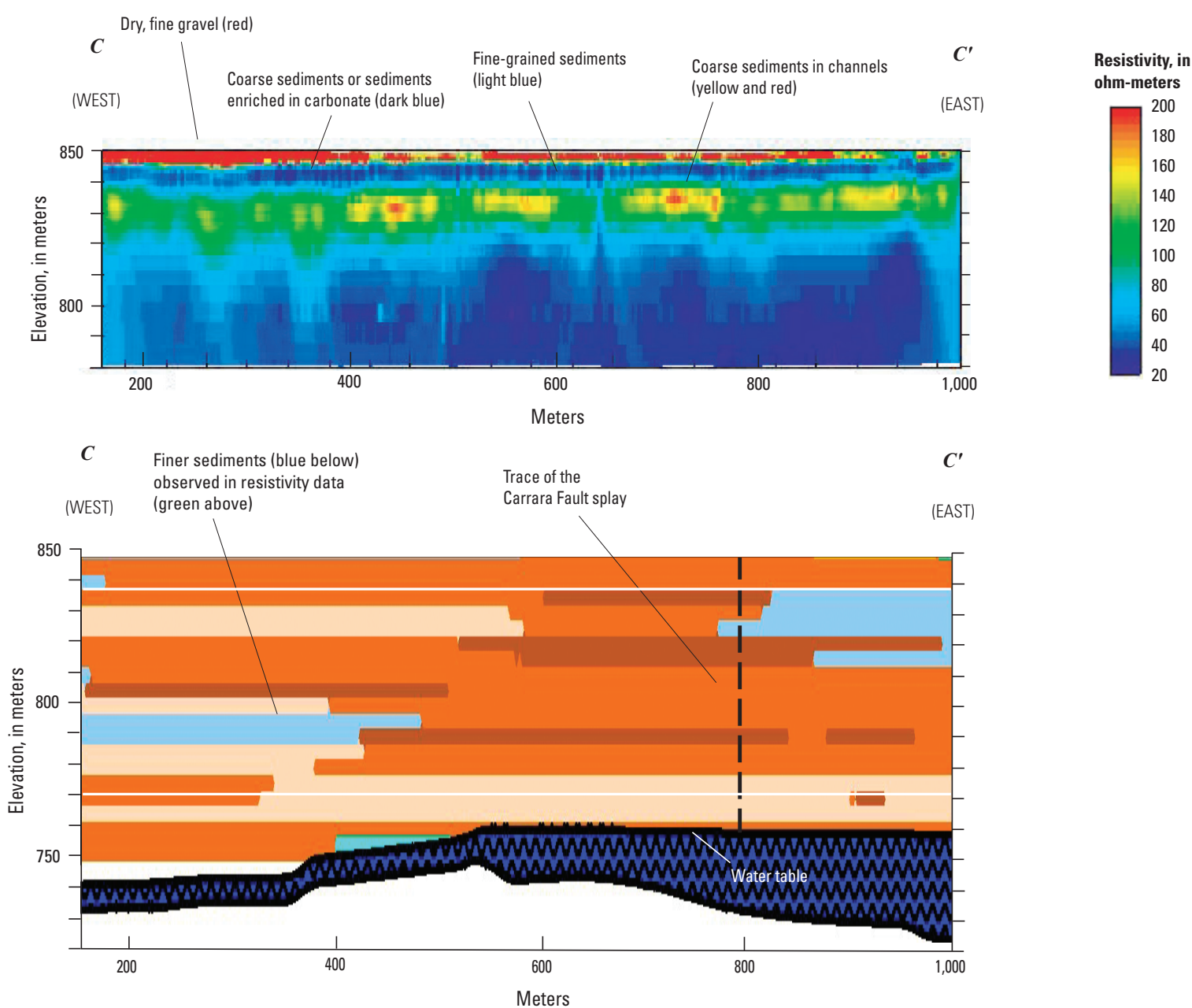

EXPLANATION

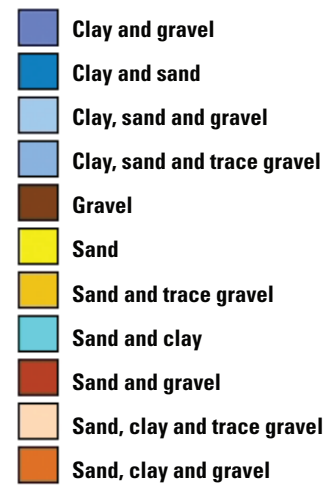

Figure 12. Comparison of the resistivity profiles (top) to the lithology profiles (bottom) along 5 lines surrounding USE. $(A)$ line $1\left(A-A^{\prime}\right) ;(B)$ line $2\left(B-B^{\prime}\right) ;(C)$ line $3\left(C-C^{\prime}\right) ;(D)$ line $4\left(D-D^{\prime}\right)$; and $(E)$ line $5\left(E-E^{\prime}\right)$. Current resistivity data (top) compared to lithologic model (bottom) at the same location. All data are at the same scale, and the area that is in both diagrams is between the two white lines on the lithology diagram. The lithology model is deeper than the resistivity data and includes the top of the water table. The base of the water table is an artifact of drill hole depth. Vertical scales are equal, and resistivity data are above the modern water table. Higher resistivity levels are warm colors (less than $150 \mathrm{ohm}-\mathrm{m}$ ) and indicate dry sediments. Lower resistivity values are cooler colors and indicate wetter sediments, the presence of dissolved soluble salts or fine-grained sand and clay.-Continued 


\section{Lines 4 and 5}
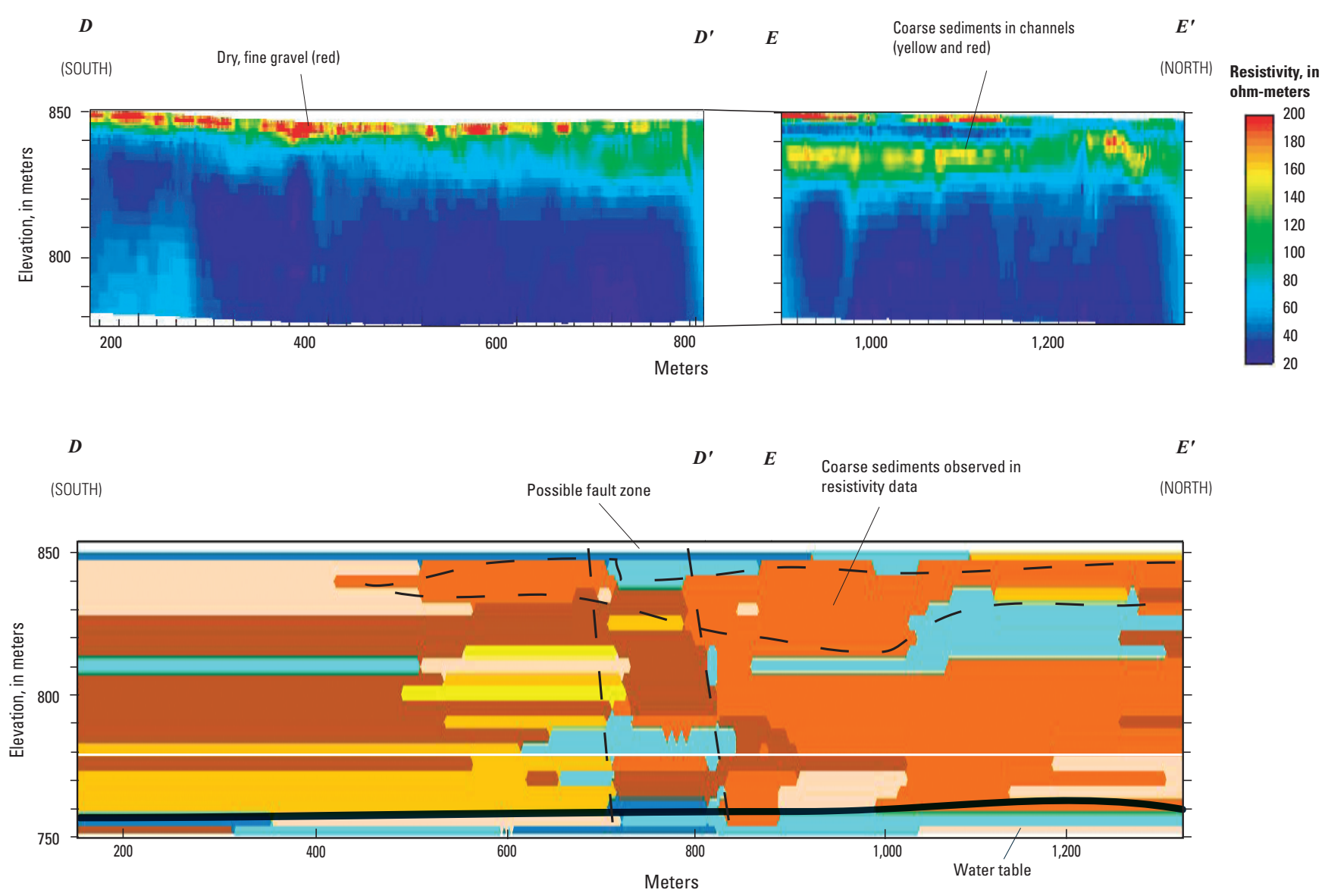

\section{EXPLANATION}

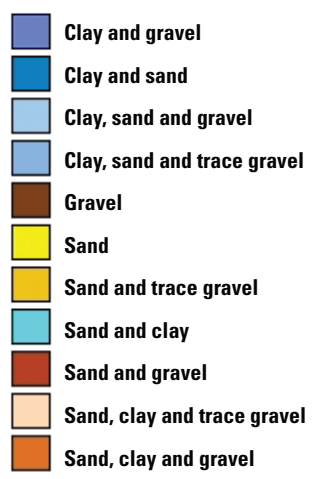

Figure 12. Comparison of the resistivity profiles (top) to the lithology profiles (bottom) along 5 lines surrounding USE. $(A)$ line $1\left(A-A^{\prime}\right) ;(B)$ line $2\left(B-B^{\prime}\right) ;(C)$ line $3\left(C-C^{\prime}\right) ;(D)$ line $4\left(D-D^{\prime}\right) ;$ and $(E)$ line $5\left(E-E^{\prime}\right)$. Current resistivity data (top) compared to lithologic model (bottom) at the same location. All data are at the same scale, and the area that is in both diagrams is between the two white lines on the lithology diagram. The lithology model is deeper than the resistivity data and includes the top of the water table. The base of the water table is an artifact of drill hole depth. Vertical scales are equal, and resistivity data are above the modern water table. Higher resistivity levels are warm colors (less than $150 \mathrm{ohm}$ $\mathrm{m}$ ) and indicate dry sediments. Lower resistivity values are cooler colors and indicate wetter sediments, the presence of dissolved soluble salts or fine-grained sand and clay.-Continued 


\section{Activity on the Carrara Fault}

The Carrara Fault has been of interest because of its proximity to USE and ADRS. The Carrara Fault is strike-slip feature that trends northwest to southeast along the general alignment of U.S. Highway 95 from the vicinity of Beatty to the southern end of Bare Mountain (Workman and others, 2002, Connor and others, 2000, fig. 1). Evidence for Quaternary activity on the Carrara Fault is expressed in aeromagnetic interpretations, the presence of suspected scarps, and the Quaternary uplift of elevated QTa gravel (Slemmons, 1997, figs. 13 and 14). Little or no geomorphic expression in Quaternary deposits suggests that recurrence of surface faulting is greater than 10,000 yrs (Anderson and Klinger, 1998). Prior to the faulted exposure described below and the three-dimensional lithologic model, many argued that most of the phenomena attributed to faulting could be explained by normal fluvial processes. The lithology model provided subsurface evidence of offset fine-grained units in the vicinity of the west splay of the Carrara Fault (fig. 9).

Suspicion has always existed that the old, elevated gravels that drape a bedrock core, south of USE (QTa on fig. 2, fig. 13), is a transpressional structure formed along a left stepover between two segments of the Carrara Fault. Based on drainage density, stream order, cross-cutting relation and different ${ }^{10} \mathrm{Be}$ exposure ages on desert pavement along the ridge crest, the uplift postdates the majority of ridge uplift and probably occurred in the late Pleistocene (Spies and others, 2000). The elevated gravels were isolated and no longer received deposition either from the Amargosa River or alluviation from the Bare Mountain fans to the east.

There also is a hydrologic gradient along the projection of the Carrara Fault, described below, that suggests a structural control of the change in water elevation. A cross section defined by a Schlumberger sounding (Bisdorf, 2002) on the north edge of USE also provided evidence for the presence of the fault (fig. 14). Ultimately, eight trenches were excavated on suspected surface traces of the fault to expose offset depositional units and to better understand the timing of Quaternary tectonics on the Carrara Fault.

Three trenches (USE306-2, 5, and 7) were mapped and the units described in detail (fig. 13, table 4). Photographs with mapped units exposed in trenches USE306-2 and 7 are included here. None of the trenches south of USE (USE306-1 through 5) exposed any faulted or fractured alluvial units. A subtle break in slope visible in the field, and also visible on the contour map produced from GPS measurements, was used to locate the trenches (fig. 13). Trench USE306-2 exposed a continuous section of mapping unit Q3, a late Pleistocene (approximately 150-300 ka, Potter and others, 2002) deposit characterized by a well-developed soil (fig. 15, table 4). Secondary carbonate is accumulated in a dense well-cemented horizon that is typical of correlative soils on the Bare Mountain fans and basin deposits (Swadley and Parrish, 1988, Potter and others, 2002). The absence of offset or fractured units indicates that the trenches did not intersect the fault or there has not been surface rupture since the deposition of unit Q3 in this area. Mapping unit Q3 surrounds, but does not drape QTa. If the QTa ridge is fault bounded by the proposed splay of the Carrara Fault, offset predated the deposition of Q3.

North of USE, trenches USE306-7 and 8 expose offset Quaternary deposits. Trench USE306-7 is described here (fig. 16, table 4) where one tectonic offset is recorded in the alluvium. Moderately well-developed vertical fault planes define a fault zone in Q3 and Q4 deposits of late Pleistocene age in Trench USE306-7 (fig. 16). The fault planes are truncated by early Holocene Q5 deposits that do not appear to be offset. The offset Q4 deposits record probable strike-slip movement after soil development on unit Q4, the youngest deposit clearly offset. Unit Q4 is late Pleistocene in age, approximately 40-85 ka (Potter and others, 2004). Unit Q5, which does not appear to have been ruptured, ranges in age from 2 to $18 \mathrm{ka}$ (Potter and others, 2004).

\section{Potentiometric Surface}

The elevation of the water table was contoured with all the available data, irrespective of the date sampled (table 4). These data were compared to the time-sensitive compilation (Walvoord and others, 2005). In the center of USE, water is intersected less than $100 \mathrm{~m}$ below the surface and increases to more than $110 \mathrm{~m}$ in the southwest corner (fig. 17). The gradient may be controlled by grain size in the depositional units at depth or by the buried splay of the Carrara Fault.

\section{Acknowledgments}

This study benefited from discussions and field work with Dennis O'Leary, Dave Stonestrom, Dave Prudic, and Brian Andraski. Thanks to John Whitney and Don Sweetkind for their helpful reviews of this document.

\section{Summary and Conclusions}

Geologic mapping by Swadley and Parish (1988) provided field evidence of the relation of the three major sources of surficial material exposed in the vicinity of US Ecology. Alluvial fans provide locally derived sediment for alluvium entering the Amargosa Basin. Alluvium in the basin axis is derived from the two major drainages that enter the basin from the north - the Amargosa River and the tributary Gold Center drainage. Eolian fines and flood sands are incorporated into the coarse alluvial material, plugging and burying deposits once exposed at the surface. 

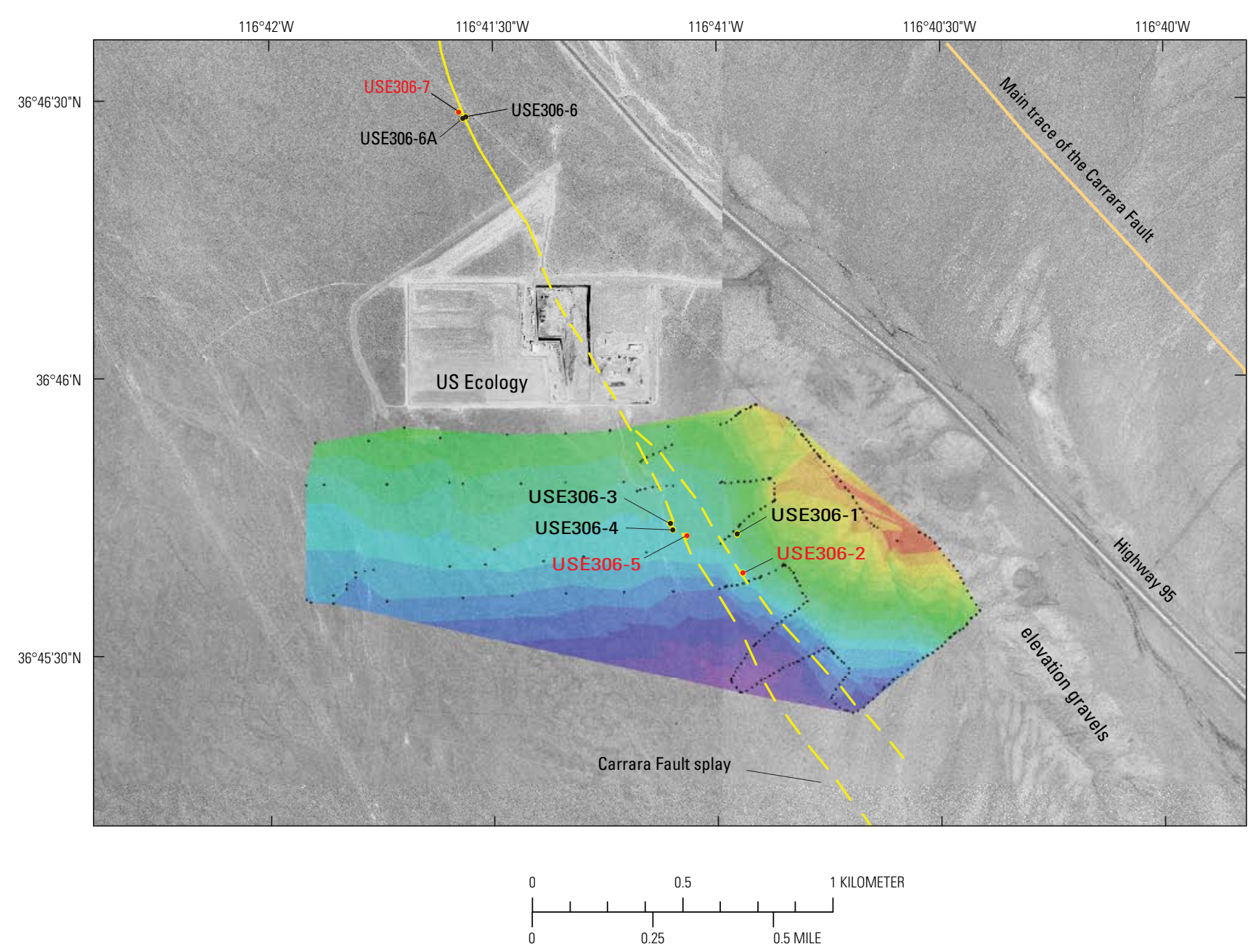

Figure 13. Contoured surface map to locate the Carrara Fault, trench locations, and projected Carrara Fault strand. The surface contour map was made from Global Positioning System reading and used to locate the Carrara Fault, trench locations, main trace of the Carrara Fault (orange, from Workman and others, 2002) and the projected Carrara Fault strand (yellow lines, dashed where buried). Eight trenches were excavated to determine if there is Quaternary offset on a projected strand of the strike-slip Carrara Fault. The trenches are labeled (USE06-1 through 6), and the three trenches with labels in red have detailed unit descriptions (USE06-2, 5, and 7). The Carrara Fault is dashed where inferred, but either not intersected or units intersected were not offset. A Global Positioning System survey was completed, and the data points were contoured to better estimate the location of the fault. The color contoured area represents an elevation change of about 17 meters, and each color contour is approximately 1 meter. The small black dots in the contoured area are the 278 locations at which the Global Positioning System measurements were made. 
A

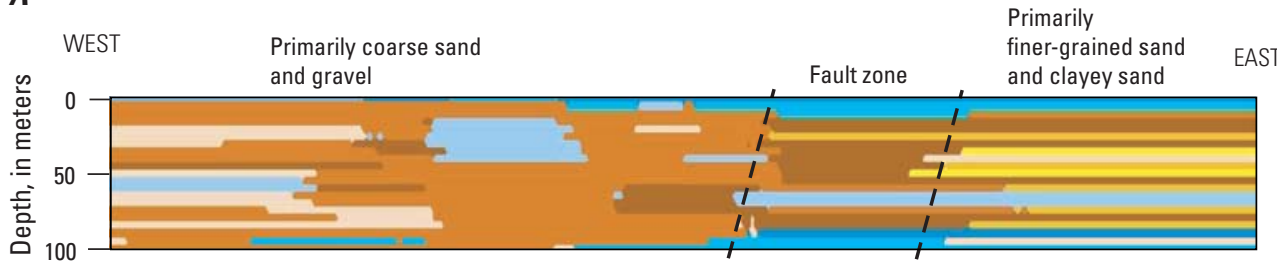

B

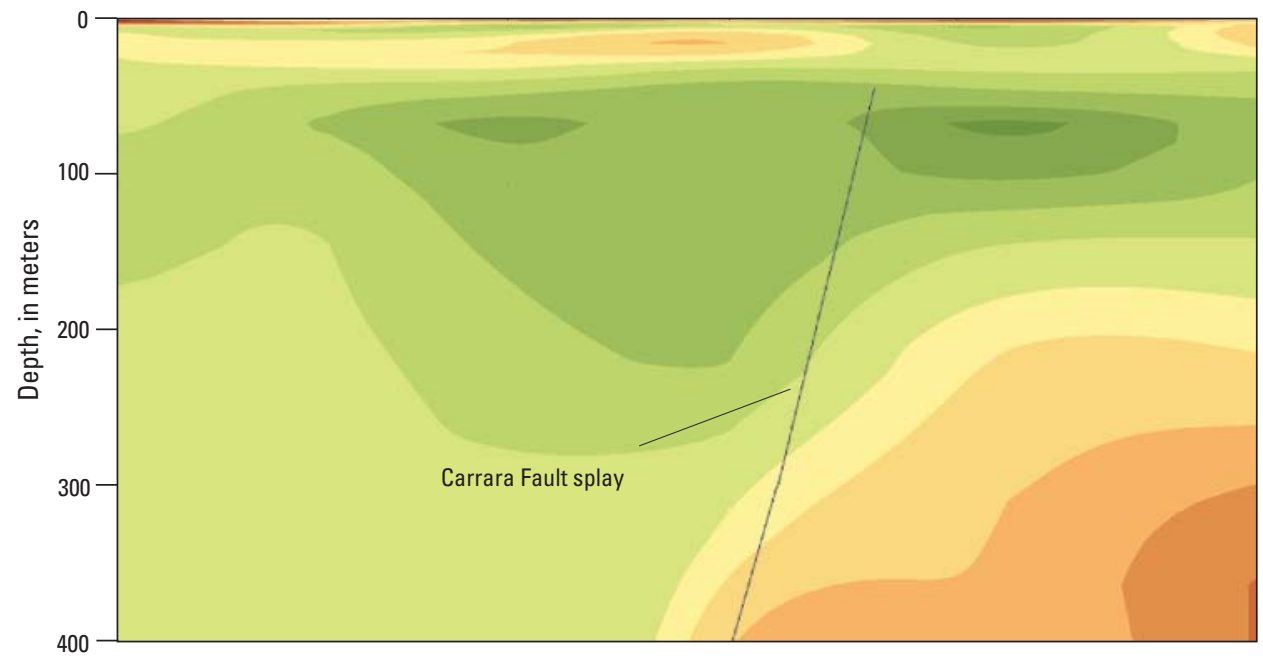

EXPLANATION

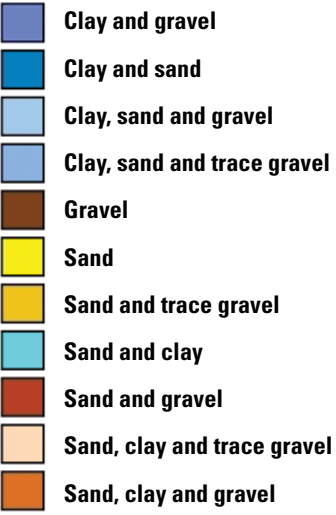

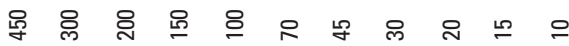

Resistivity in Ohm-meters

Figure 14. Comparison of $(A)$ lithology model and $(B)$ Schlumberger sounding at the location of the inferred splay of the Carrara Fault. A cross section of the lithology model, made at the same location as the Schlumberger sounding (Bisdorf, 2002), supports the resistivity data suggesting the presence of a splay of the Carrara Fault. Lithologic units west of the subsurface interpretation primarily are coarse sand and gravel and east, finer-grained sand and clayey sand. Vertical and horizontal scales are equal. 
[bd, boulder; cob, cobble; peb, pebble; grav, gravel]

\begin{tabular}{|c|c|c|c|c|c|c|c|c|c|c|c|c|}
\hline \multirow[b]{2}{*}{$\begin{array}{l}\text { Strati- } \\
\text { graphic } \\
\text { unit }\end{array}$} & \multirow[b]{2}{*}{$\begin{array}{c}\text { Horizon } \\
\text { (boundary) }\end{array}$} & \multirow[b]{2}{*}{$\begin{array}{l}\text { Depth or } \\
\text { thickness } \\
\text { range } \\
\text { (cm) }\end{array}$} & \multicolumn{2}{|c|}{ Color } & \multirow[b]{2}{*}{ Texture } & \multirow[b]{2}{*}{$\begin{array}{l}\text { Structure } \\
\text { (primary and } \\
\text { secondary) }\end{array}$} & \multirow[b]{2}{*}{$\begin{array}{l}\text { Consis- } \\
\text { tence } \\
\text { (dry, moist, } \\
\text { wet) }\end{array}$} & \multirow[b]{2}{*}{$\begin{array}{l}\text { Clay } \\
\text { films }\end{array}$} & \multirow[b]{2}{*}{$\begin{array}{l}\text { Secondary } \\
\mathrm{CaCO}_{3} \\
\text { (gravel and } \\
\text { dissemi- } \\
\text { nated) }\end{array}$} & \multirow{2}{*}{\multicolumn{2}{|c|}{$\begin{array}{l}\text { Parent } \\
\text { material } \\
\text { and } \\
\text { lithology- } \\
\text { sorting, } \\
\text { angularity, } \\
\text { bedding, } \\
\text { imbrication, } \\
\text { support }\end{array}$}} & \multirow[b]{2}{*}{$\begin{array}{l}\text { Miscella- } \\
\text { neous- } \\
\text { roots, pores, } \\
\mathrm{SiO}_{2} \text {, oxida- } \\
\text { tion, salts, } \\
\text { concretions }\end{array}$} \\
\hline & & & $\begin{array}{c}\text { Dry } \\
\text { (<gravel or } \\
\text { ped face) }\end{array}$ & $\begin{array}{c}\text { Wet } \\
\text { (<gravel or } \\
\text { ped face) }\end{array}$ & & & & & & & & \\
\hline \multicolumn{13}{|c|}{ USE306-2 } \\
\hline Q3 & Av (as) & & $10 Y R 7 / 2$ & $10 \mathrm{YR} 4.5 / 4$ & SL & 3 ves $\mathrm{m}$ to $\mathrm{pl}$ & lo, np & & $\begin{array}{c}\text { dissemi- } \\
\text { nated }\end{array}$ & $<10$ & & \\
\hline Q3 & $\mathrm{Bk} 1(\mathrm{cw})$ & & 10YR 7.5/2 & 10YR 5/4 & SL & 2 co sbk & sh, hp & & II and diss & 20 & & \\
\hline Q3 & $\mathrm{Bk} 2$ (gs) & & $7.5 \mathrm{YR} 8 / 2$ & $7.5 \mathrm{YR} 4 / 3$ & $\mathrm{~S}$ & $2 \mathrm{~m}$ to co $\mathrm{pl}$ & sh, np & & $\begin{array}{l}\text { III and } \\
\text { weak } \\
\text { plates }\end{array}$ & $30-40$ & & \\
\hline Q3 & $\mathrm{Bk} 3$ & & 7.5YR 8/2 & $7.5 \mathrm{YR} 4 / 3$ & $\mathrm{~S}$ & $\mathrm{~m}$ & sh & & III & $30-40$ & & hz disappears \\
\hline Q3 & $\mathrm{Bk} 4$ & & $7.5 \mathrm{YR} 6 / 3$ & $7.5 \mathrm{YR} 4 / 3$ & $\mathrm{~S}$ & $\mathrm{~m}$ to $3 \mathrm{~m} \mathrm{pl}$ & sh & & $\begin{array}{l}\text { I, stringers } \\
\text { III }\end{array}$ & $30-40$ & & \\
\hline \multicolumn{13}{|c|}{ USE306-5 } \\
\hline Q5 & Av (as) & & 10YR $6.5 / 2$ & $10 \mathrm{YR} 4.5 / 3$ & SL & $2 \mathrm{~m}$ to co $\mathrm{pl}$ & ns, np, so & & & $<10$ & & \\
\hline Q5 & Bk1 (as) & & 10YR 6/3 & 10YR 5/4 & SL & $\mathrm{sg}$ & $\mathrm{ns}, \mathrm{np}$, so & & & $<10$ & & $\begin{array}{l}\text { browner than } \\
\text { horizon } \\
\text { below }\end{array}$ \\
\hline Q5 & $\mathrm{Bk} 2(\mathrm{cs})$ & & $\begin{array}{c}10 \mathrm{YR} \\
8 / 2.5-7 / 3\end{array}$ & $10 Y R 5 / 4$ & $\mathrm{LS}+$ & f to co sbk & sh, np, vss & & II & $20-30$ & & $\begin{array}{l}\text { base of silty } \\
\text { sand }\end{array}$ \\
\hline
\end{tabular}


Table 4. Soil unit descriptions of deposits exposed in trenches USE306-2, 5, and 7.-Continued

[bd, boulder; cob, cobble; peb, pebble; grav, gravel]

\begin{tabular}{|c|c|c|c|c|c|c|c|c|c|c|c|c|}
\hline \multirow[b]{2}{*}{$\begin{array}{l}\text { Strati- } \\
\text { graphic } \\
\text { unit }\end{array}$} & \multirow[b]{2}{*}{$\begin{array}{c}\text { Horizon } \\
\text { (boundary) }\end{array}$} & \multirow[b]{2}{*}{$\begin{array}{l}\text { Depth or } \\
\text { thickness } \\
\text { range } \\
\text { (cm) }\end{array}$} & \multicolumn{2}{|c|}{ Color } & \multirow[b]{2}{*}{ Texture } & \multirow[b]{2}{*}{$\begin{array}{l}\text { Structure } \\
\text { (primary and } \\
\text { secondary) }\end{array}$} & \multirow[b]{2}{*}{$\begin{array}{l}\text { Consis- } \\
\text { tence } \\
\text { (dry, moist, } \\
\text { wet) }\end{array}$} & \multirow[b]{2}{*}{$\begin{array}{l}\text { Clay } \\
\text { films }\end{array}$} & \multirow[b]{2}{*}{$\begin{array}{l}\text { Secondary } \\
\mathrm{CaCO}_{3} \\
\text { (gravel and } \\
\text { dissemi- } \\
\text { nated) }\end{array}$} & \multirow{2}{*}{\multicolumn{2}{|c|}{$\begin{array}{l}\text { Parent } \\
\text { material } \\
\text { and } \\
\text { lithology- } \\
\text { sorting, } \\
\text { angularity, } \\
\text { bedding, } \\
\text { imbrication, } \\
\text { support }\end{array}$}} & \multirow[b]{2}{*}{$\begin{array}{c}\text { Miscella- } \\
\text { neous- } \\
\text { roots, pores, } \\
\mathrm{SiO}_{2^{\prime}} \text { oxida- } \\
\text { tion, salts, } \\
\text { concretions }\end{array}$} \\
\hline & & & $\begin{array}{c}\text { Dry } \\
\text { (<gravel or } \\
\text { ped face) }\end{array}$ & $\begin{array}{c}\text { Wet } \\
\text { (<gravel or } \\
\text { ped face) }\end{array}$ & & & & & & & & \\
\hline Q5 & $2 \mathrm{Bk} 3$ & & $10 \mathrm{YR} 8 / 3$ & $10 \mathrm{YR} 5 / 3$ & SL & $\begin{array}{l}\mathrm{m} \text { to sg, weakly } \\
\mathrm{pl} \text { in places }\end{array}$ & $\mathrm{ns}, \mathrm{np}$ & & $\mathrm{II}+$ to III & 80 & & \\
\hline \multicolumn{13}{|c|}{ USE306-5-Continued } \\
\hline Q5 & 2Bk4 (as) & & 10 YR $7 / 2$ & $10 \mathrm{YR} 4 / 3$ & SL- & $\mathrm{m}$ to $\mathrm{sg}$ & $\mathrm{ns}, \mathrm{np}$ & & II- & $\begin{array}{c}80, \text { peb cob } \\
\text { grav }\end{array}$ & $\begin{array}{l}\text { weakly } \\
\text { imbricated, } \\
\text { poorly con- } \\
\text { solidated }\end{array}$ & \\
\hline Q3 & 3Btkb (as) & & $7.5 Y R 5 / 4$ & $7.5 \mathrm{YR} 4 / 4$ & SL & $2 \mathrm{f}$ to $\mathrm{m}$ abk & $\mathrm{ns}, \mathrm{np}$ & $\mathrm{n} \mathrm{cf} g r$ & I & $\begin{array}{c}50-70, \text { peb } \\
\text { grav }\end{array}$ & & $\begin{array}{c}\text { top of buried } \\
\text { soil (Q3) }\end{array}$ \\
\hline Q3 & $3 \mathrm{~Kb}$ & & 7.5 YR 7.5/2 & 7.5YR 5/6 & SL & $\mathrm{m}$ to $1-2 \mathrm{~m}$ abk & $\mathrm{ns}, \mathrm{p}$ & & III & peb grav & & $\begin{array}{l}\text { not inter- } \\
\text { sected by } \\
\text { possible } \\
\text { fracture, } \\
\text { unit is } \\
\text { eroded by } \\
\text { channel in } \\
\text { places }\end{array}$ \\
\hline
\end{tabular}

USE306-7

\begin{tabular}{|c|c|c|c|c|c|c|c|}
\hline Q5 & Av (ac) & $10-20$ & $10 \mathrm{YR} 6 / 2$ & $10 \mathrm{YR} 4 / 3$ & SL & $\begin{array}{c}\text { thin plates }<3 \\
\mathrm{~cm}\end{array}$ & \\
\hline Q5 & $\mathrm{AB}$ & & & & & $2 \mathrm{~m}$ to co sbk & I \\
\hline Q5 & Bk1 (ac) & & 10YR $7 / 2$ & 10YR 5/3 & LS & $\begin{array}{l}\text { erodes to mas- } \\
\text { sive columnar } \\
\text { structure }\end{array}$ & $\begin{array}{l}\text { carbonate } \\
\text { coats pf }\end{array}$ \\
\hline
\end{tabular}




\begin{tabular}{|c|c|c|c|c|c|c|c|c|c|c|c|c|}
\hline \multirow[b]{2}{*}{$\begin{array}{l}\text { Strati- } \\
\text { graphic } \\
\text { unit }\end{array}$} & \multirow[b]{2}{*}{$\begin{array}{c}\text { Horizon } \\
\text { (boundary) }\end{array}$} & \multirow[b]{2}{*}{$\begin{array}{l}\text { Depth or } \\
\text { thickness } \\
\text { range } \\
\text { (cm) }\end{array}$} & \multicolumn{2}{|c|}{ Color } & \multirow[b]{2}{*}{ Texture } & \multirow[b]{2}{*}{$\begin{array}{c}\text { Structure } \\
\text { (primary and } \\
\text { secondary) }\end{array}$} & \multirow[b]{2}{*}{$\begin{array}{l}\text { Consis- } \\
\text { tence } \\
\text { (dry, moist, } \\
\text { wet) }\end{array}$} & \multirow[b]{2}{*}{$\begin{array}{l}\text { Clay } \\
\text { films }\end{array}$} & \multirow[b]{2}{*}{$\begin{array}{l}\text { Secondary } \\
\mathrm{CaCO}_{3} \\
\text { (gravel and } \\
\text { dissemi- } \\
\text { nated) }\end{array}$} & \multirow{2}{*}{\multicolumn{2}{|c|}{$\begin{array}{l}\text { Parent } \\
\text { material } \\
\text { and } \\
\text { lithology- } \\
\text { sorting, } \\
\text { angularity, } \\
\text { bedding, } \\
\text { imbrication, } \\
\text { support }\end{array}$}} & \multirow[b]{2}{*}{$\begin{array}{l}\text { Miscella- } \\
\text { neous- } \\
\text { roots, pores, } \\
\mathrm{SiO}_{2} \text {, oxida- } \\
\text { tion, salts, } \\
\text { concretions }\end{array}$} \\
\hline & & & $\begin{array}{c}\text { Dry } \\
\text { (<gravel or } \\
\text { ped face) }\end{array}$ & $\begin{array}{c}\text { Wet } \\
\text { (<gravel or } \\
\text { ped face) }\end{array}$ & & & & & & & & \\
\hline \multicolumn{13}{|c|}{ USE306-7-Continued } \\
\hline Q5 & 2Bk2 (gs) & & 10YR 7/2 & $10 \mathrm{YR} 4 / 3$ & $\mathrm{~S}$ & $\operatorname{sg}$ & & & I+ to II- & $\begin{array}{c}\text { peb cob } \\
\text { grav }\end{array}$ & $\begin{array}{l}\text { mod imbrica- } \\
\text { tion }\end{array}$ & $\begin{array}{l}>\text { infiltrated } \\
\text { silt than hz } \\
\text { below }\end{array}$ \\
\hline Q5 & 2Bk3 (ac) & & 10 YR $5.5 / 2$ & $10 \mathrm{YR} 3 / 3$ & $\mathrm{v} \cos$ & sg & & & $\begin{array}{l}\text { I- thin and } \\
\text { patchy }\end{array}$ & $\begin{array}{l}\text { 70, peb cob } \\
\text { grav }\end{array}$ & & \\
\hline Q4 & $\begin{array}{r}\text { 3Bk1b1 } \\
(\mathrm{gw})\end{array}$ & 50 & 10YR 6/2 & $10 Y R 4 / 4$ & $\mathrm{~S}$ & $2 \mathrm{f}$ to $\mathrm{m} \mathrm{sbk}$ & $\mathrm{ns}, \mathrm{np}$ & & $\begin{array}{l}\text { II to fila- } \\
\text { ments }\end{array}$ & peb grav & & \\
\hline Q4 & $\begin{array}{c}4 \mathrm{Bk} 2 \mathrm{~b} 1 \\
\quad(\mathrm{ac})\end{array}$ & & 10YR 5/1 & $10 \mathrm{YR} 3 / 2.5$ & $\mathrm{~S}$ & sg & ns, np & & $\mathrm{I}+$ patchy & $\begin{array}{c}\text { peb cob } \\
\text { grav }\end{array}$ & $\begin{array}{l}\text { mod well im- } \\
\text { brication }\end{array}$ & \\
\hline Q3 & $5 \mathrm{~Kb} 2$ & & 10 YR $6.5 / 2$ & $10 Y R 4 / 4$ & & $\mathrm{~m}$ to $\mathrm{sg}$ & $\mathrm{ns}, \mathrm{np}$ & & III & peb grav & $\begin{array}{l}\text { poor to mod } \\
\text { imbrication }\end{array}$ & \\
\hline
\end{tabular}


Explanation of soil and unit descriptions (Birkeland, 1999).

\section{Master Horizon}

\begin{tabular}{|c|c|c|}
\hline A & \multicolumn{2}{|c|}{ Organic matter accumulation, zone of elluviation of clay, sesquioxides, silica, gypsum, carbonate, and/or salts } \\
\hline $\mathrm{K}$ & \multicolumn{2}{|c|}{ Horizon engulfed with carbonate to the extent that the horizon morphology is determined by the carbonate } \\
\hline $\mathrm{C}$ & \multicolumn{2}{|c|}{ Horizon that may be similar to parent material, includes unaltered and weathered material } \\
\hline $\mathrm{b}$ & \multicolumn{2}{|l|}{ buried soil horizon } \\
\hline $\mathrm{k}$ & \multicolumn{2}{|l|}{ accumulation of carbonates } \\
\hline $\mathrm{t}$ & \multicolumn{2}{|l|}{ accumulation of clay } \\
\hline $\mathrm{V}$ & \multicolumn{2}{|l|}{ vesicular structure } \\
\hline Distinctness & Topography & Soil Texture \\
\hline a, abrupt & s, smooth & v co, very coarse \\
\hline c, clear & w, wavy & $\mathrm{S}$, sand \\
\hline \multirow[t]{2}{*}{ g, gradual } & & LS, loamy sand \\
\hline & & SL, sandy loam \\
\hline \multicolumn{3}{|r|}{ Soil Structure } \\
\hline 2 , moderate & vco, very coarse (v thick) & abk, angular blocky \\
\hline 3, strong & & sbk, subangular blocky \\
\hline
\end{tabular}

\section{Soil Consistency/Plasticity}

\begin{tabular}{lll}
\hline Dry & Moist & Wet \\
\hline lo, loose & lo loose & so,po non-sticky or plastic \\
so, soft & vfr very friable & vss,vps very slightly sticky or plastic \\
sh, slightly hard & fr friable & ss,ps slightly sticky or plastic \\
h, hard & fi firm & s,p sticky or plastic \\
vh, very hard & vfi very firm & vs,vp very sticky or plastic \\
eh, extremely hard & efi extremely firm & \\
\hline
\end{tabular}




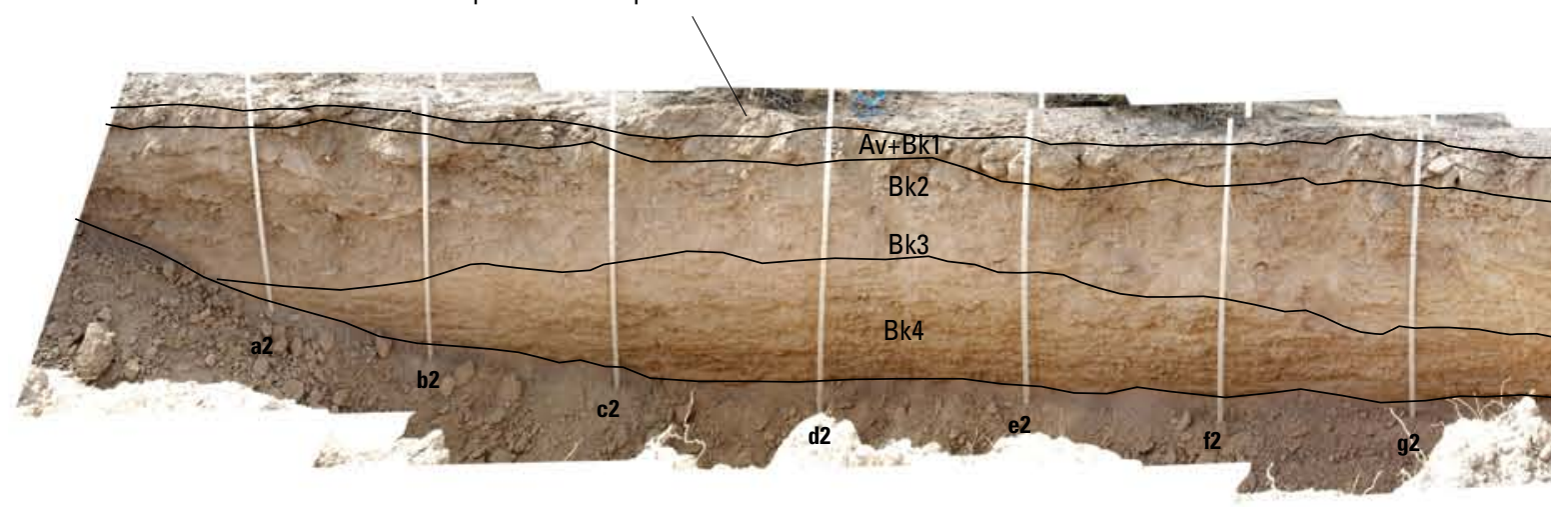

2

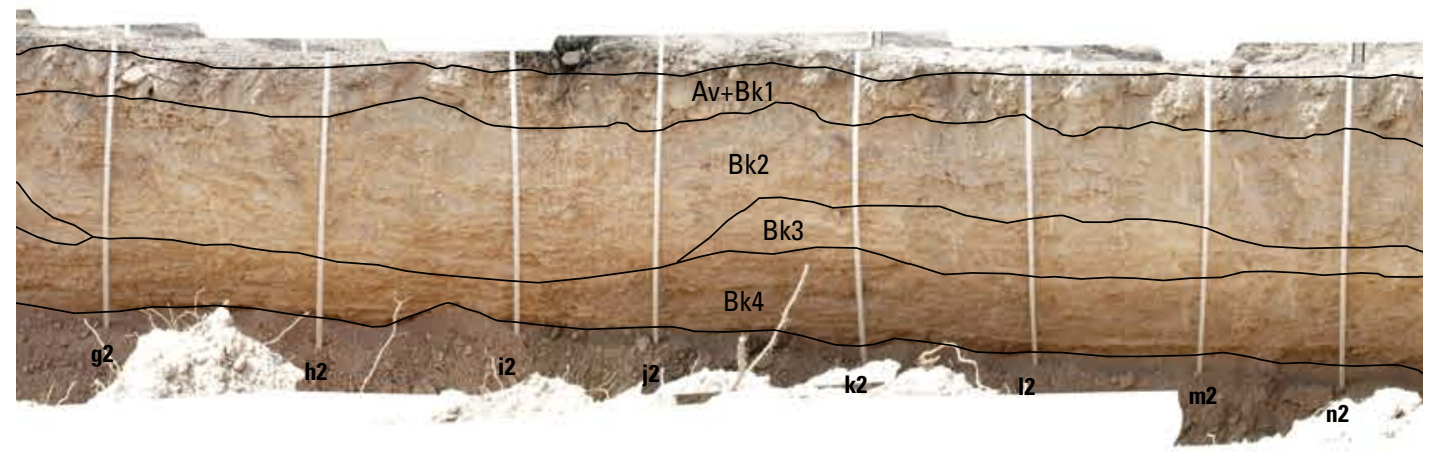

3

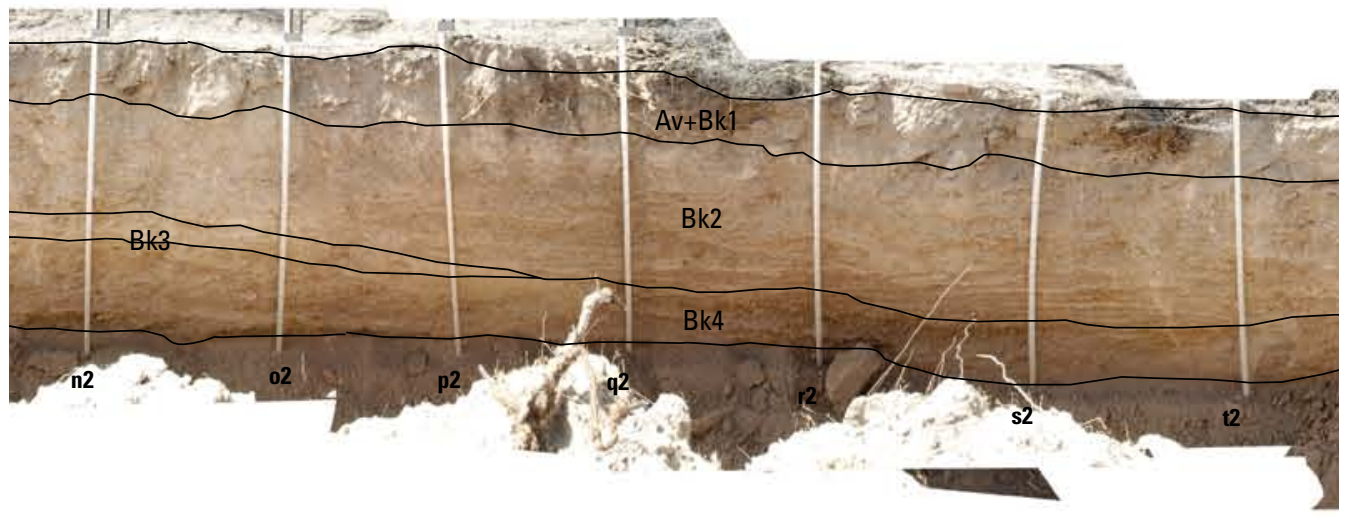

\section{Trench USE306-2 East end of the south wall}

Figure 15. Trench USE306-2. Trench USE306-2 separated into six sections from east to west (1-6). None of the deposits exposed in the trench have been offset, and there are no fractures to suggest any movement as a result of tectonic activity. White poles are approximately 1 meter apart, and the trench is about 1.7 meters deep. 


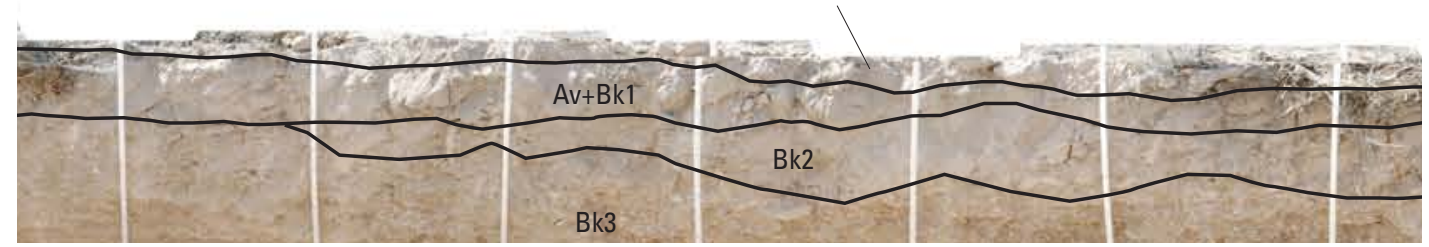

5

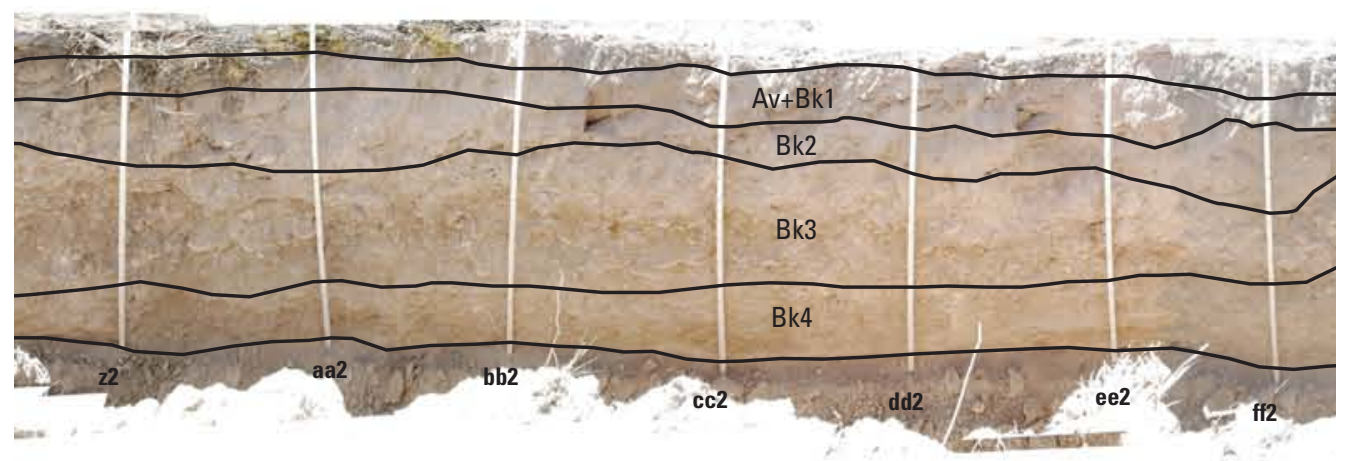

6

$\mathrm{Av}+\mathrm{Bk} 1$

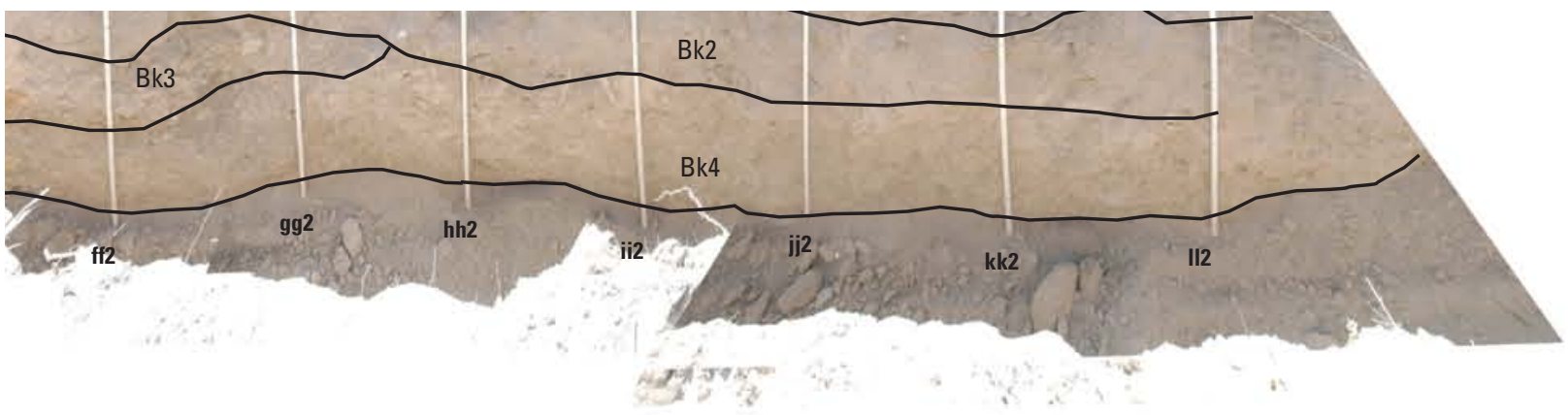

Trench USE306-2 West end of the south wall

Figure 15. Trench USE306-2. Trench USE306-2 separated into six sections from east to west (1-6). None of the deposits exposed in the trench have been offset, and there are no fractures to suggest any movement as a result of tectonic activity. White poles are approximately 1 meter apart, and the trench is about 1.7 meters deep.-Continued 

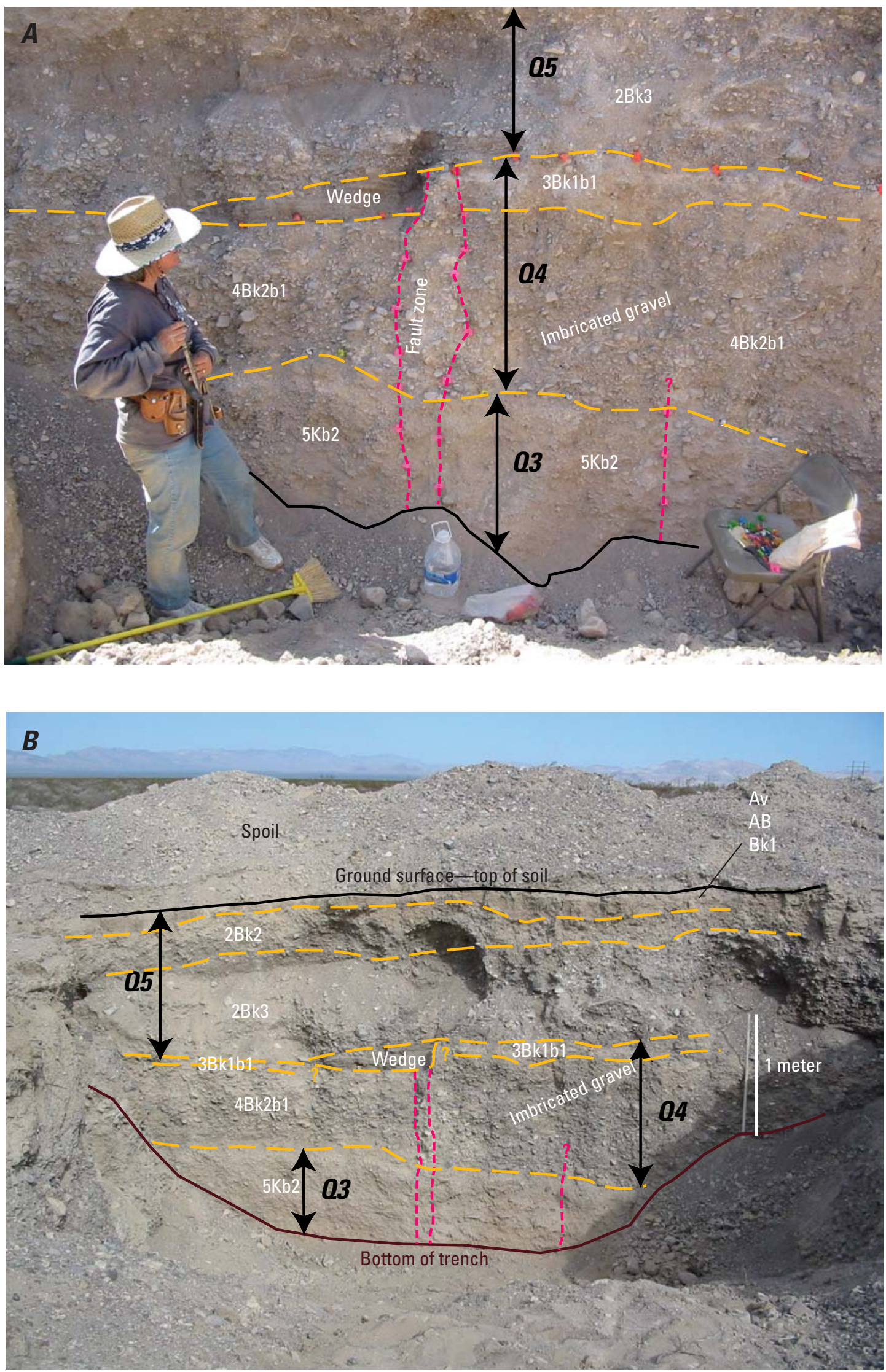

Figure 16. Exposure of the Carrara Fault in Trench USE306-7 $(A)$ centered in the fault zone, and $(B)$ the entire trench exposure. 

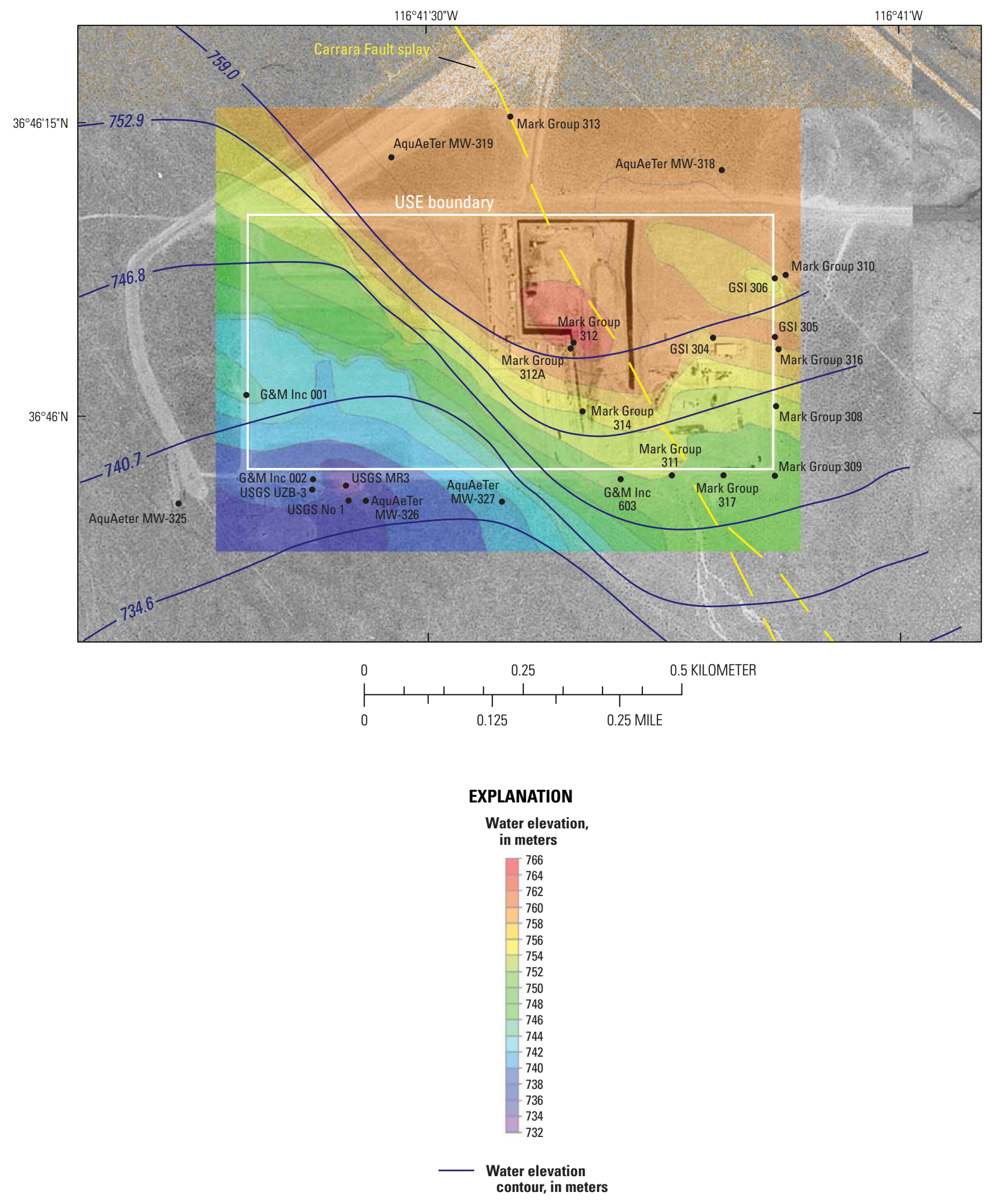

- Well location

Figure 17. Comparison of the long-term average and the time-dependent water elevation (meters). The 37 boreholes with water elevations, used to generate the colored contours, are located with a filled circle. All water levels were used, irrespective of sampling date, so the color contours represent a long-term average. The red lines are from Walvoord and others (2005) and were generated from time-sensitive water-elevation data. The gradient may be controlled by grain size in the depositional units at depth, or by the buried splay of the Carrara Fault. 
The Amargosa Basin was closed until the headwaters of the Amargosa River connected the basin to Oasis Valley at the Beatty Narrows between 150 and $50 \mathrm{ka}$. The basin remained closed and water did not exit the basin at Eagle Mountain and flow into the Tecopa Basin until the late Pleistocene (approximately $130 \mathrm{ka})$.

Groundwater has intersected the surface of the basin in the vicinity of Ash Meadows. These deposits were eroded when the Amargosa River was integrated with the Tecopa Basin. The fine-grained groundwater deposits were eroded and exposed above the active drainage. The Amargosa River was integrated from Oasis Valley to Tecopa Basin and seasonally flowing.

Optically Simulated Luminescence technique was used to date borehole sediment samples at USE. Along with dated buried volcanic ash and basalt, these ages provided estimated rates of alluvial valley aggradation. Thermoluminescence (TL) appears to over estimate late Pleistocene aggradation rates, probably because fine-grained sediment is not "zeroed" prior to burial. Long-term aggradation rates determined from the volcanic samples are low $(0.02 \mathrm{~mm} / \mathrm{yr})$. Climatic or tectonic effects, or both, are recorded in the deposits less than $70 \mathrm{ka}$ from the borehole samples. These samples may range in age from 5 to $65 \mathrm{ka}$ and may support the hypothesis that alluviation occurred following regional climate shifts from pluvial to interpluvial climates when material was available to transport.

Geologic data compiled from 67 boreholes at USE and from surrounding studies were used to construct a three-dimensional lithologic model of the subsurface at USE. No volcanic units or fine-grained playa/palustrine deposits were present and intersected. The top 100 meters is characterized by repeated stacks of fining-upward alluvial sequences between 4- and 5 -m thick. Coarse gravel, eroded into the underlying alluvium, grades upward to finer sand and sandy clay. The threedimensional model displays offset fine-grained deposits that are coincident with a geophysical projection of the Carrara Fault.

Trenches were excavated across projections of the subsurface lineament. Quaternary deposits as old as 150-300 ka were not offset south of the waste site, however, trenches north of USE did display offset as young as 40-85 ka. Because of the strike-slip nature of the fault, total offset was not determined in this study.

Resistivity profiles were compared to the modeled subsurface lithologies above the water table to better understand the parameters measured in the resistivity profiles. Moisture, sediment size and accumulation of secondary salts control resistivity values observed in the vicinity of USE.

\section{References Cited}

Abraham, Jared D., and Lucius, Jeffrey E., 2004, Direct current resistivity profiling to study distribution of water in the unsaturated zone near the Amargosa Desert Research Site, Nevada: U.S. Geological Survey Open-File Report 2004-1319, 16 p.

Anderson, L.W., and Klinger, R.E., 1996, Beatty Scarp and Carrara Fault: Friends of the Pleistocene Field Trip Guide for Yucca Mountain, Nevada, October 9-11, p. 217-223.

Belcher, Wayne R., ed., 2004, Death Valley regional groundwater flow system, Nevada and California-Hydrogeologic framework and transient groundwater flow model: U.S. Geological Survey Scientific Investigations Report 2004-5205, 408 p., 2 plates.

Birkeland, P.W, 1999, Soils and geomorphology: Oxford University Press, New York, $430 \mathrm{p}$.

Bisdorf, Robert J., 2002, Schlumberger soundings at the Amargosa Desert Research Site, Nevada: U.S. Geological Survey Open-File Report 2002-140, 65 p.

Bull, William B., 1991, Geomorphic responses to climatic change: Oxford University Press, New York, 326 p.

Connor, C.B., Stamatakos, J.A., Ferrill, D.A., Hill, B.E., Ofoegbu, G.I., Conway, F.M., Sagar, Budhi, and Trapp, John, 2000, Geologic factors controlling patterns of smallvolume basaltic volcanism-Application to a volcanic hazards assessment at Yucca Mountain, Nevada: J. Geophys. Res., v. 105, n. B1, p. 417-432.

Dethier, David P., 2001, Pleistocene incision rates in the western United States calibrated using Lava Creek B tephra: Geology, v. 29, no. 9, p. 783-786.

Fridrich, C.J., Whitney, J.R., Hudson, M.R., and Crowe, B.M., 1999, Space-time patterns of late Cenozoic extension, vertical axis rotation, and volcanism in the Crater Flat basin, southwest Nevada: in Wright, L.A., and Troxel, B.W., eds., Cenozoic Basins of the Death Valley Region: Geological Society of America Special Paper 333, p. 197-212.

Fridrich, Christopher J., Minor, Scott A., Slate, Janet L., and Ryder, Phil L., 2007, Geologic Map of Oasis valley springdischarge area and vicinity, Nye County, Nevada: U.S. Geological Survey Scientific Investigations Map 2957, 25 p., 1 plate, scale 1:50,000. 
Izett, G.A., Pierce, K.L., Naeser, N.D., and Jaworowski, C., 1992, Isotopic dating of Lava Creek B tephra in terrace deposits along the Wind River, Wyoming: Geological Society of America Abstracts with Programs, v. 24, no. 7, p. A102.

Keefer, William R., Whitney, John W., and Taylor, Emily M., eds., 2004, Quaternary paleoseismology and stratigraphy of the Yucca Mountain area, Nevada: U.S. Geological Survey Professional Paper 1689, CD-ROM, 212 p., 26 plates.

Menges, Christopher M., 2008, Multistage late Cenozoic evolution of the Amargosa River drainage, southwestern Nevada and eastern California: in Reheis, Marith C., Hersherler, Robert, and Miller, David M., eds., Late Cenozoic drainage history of the Southwestern Great Basin and Lower Colorado River Region-Geologic and Biotic Perspectives: Geological Society of America Special Paper 439, p. 39-90.

Potter, Christopher J., Dickerson, Robert P., Sweetkind, Donald S., Drake, Ronald M., II, Taylor, Emily M., Fridrich, Christopher J., San Juan, Carma A., and Day, Warren C., 2002, Geologic map of the Yucca Mountain region, Nye County, Nevada: U.S. Geological Survey IMAP 2755, 1 map, scale 1:50,000.

Sarna-Wojcicki, A.M., Morrison, S.D., Meyer, C.E., and Hillhouse, J.W., 1987, Correlation of upper Cenozoic tephra layers between sediments of the western United States and eastern Pacific Ocean and comparison with biostratigraphic and magnetostratigraphic age data: Geological Society of America Bulletin, v. 98, p. 207-223.

Slemmons, D.B., 1997, Carrara fault in southern Nevada from paleoseismic, geologic and geophysical evidence-Implications to the earthquake hazards and tectonics near Yucca Mountain, Nevada: EOS Transactions AGU, v. 78, n. 46, Fall Meeting Supplement, p. F453.

Spies, C.S., Whitney, J.W., Gosse, J., Slemmons, D.B., and Caffee, M., 2000, Terrestrial cosmogenic nuclide dating of deformed alluvium along the Carrara Fault in the northern Amargosa Desert, Nye County, Nevada: GSA Abstracts with Programs, v. 32, no. 7, p. A-166.

Stamatakos, J.A., Connor, C.B., Hill, B.E., Magsino, S. Lane, and Ferril, D.A., 1997, The Carrara Fault in southwestern Nevada revealed from detailed gravity and magnetic results-Implications for seismicity, volcanism, and tectonics near Yucca Mountain, Nevada: EOS Transactions AGU, v. 78, no. 46, Fall Meeting Supplement, p. F453.
Stonestrom, David A., Prudic, David E., Laczniak, Randell J., Akstin, Katherine C., Boyd, Robert A., and Henkelman, Katherine K., 2003, Estimates of deep percolation beneath native vegetation, irrigated fields, and the Amargosa River channel, Amargosa Desert, Nye County, Nevada: U.S. Geological Survey Open-File Report 2003-104, 88 p.

Swadley, WC, and Parrish, L.D., 1988, Surficial geologic map of the Bare Mountain quadrangle, Nye County, Nevada: U.S. Geological Survey Miscellaneous Investigation Series Map I-1826, 1 sheet, scale 1:48,000.

Taylor, E. M. and Sweetkind, D. S., 2010, Three-dimensional geologic map of the Cenozoic basin fill, Amargosa Desert Basin, Nevada and California: U.S. Geological Survey Scientific Investigations Map, 2 sheets.

Workman, Jeremiah B., Menges, Christopher M., Page, William R., Taylor, Emily M., Ekren, E. Bartlett, Rowley, Peter D., Dixon, Gary L., Thompson, Ren A., and Wright, Lauren A., 2002, Geologic map of the Death Valley groundwater model area, Nevada and California: U.S. Geological Survey Miscellaneous Field Studies Map 2381, 2 sheets, scale 1:250,000.

Winograd, I.J., Coplen, T.B., Landwehr, J.M., Riggs, A.C., Ludwig, K.R., Szabo, B.J., Kolesar, P.T., and Revesz, K.M., 1992, Continuous 500,000-year climate record from vein calcite in Devils Hole, Nevada: Science, v. 258, p. $255-260$.

Winograd, Isaac J., Landwehr, Jurate M., Coplen, Tyler B., Sharp, Warren D., Riggs, Alan C., Ludwig, Kenneth R., and Kolesar, Peter T., 2006, Devils Hole, Nevada, $\delta 180$ record extended to the mid-Holocene: Quaternary Research, v. 66, no. 2, p. 202-212. (also available at http://www.sciencedirect.com/science/article/B6WPN4KJDX0W-1/2/ad8a75c0d59809bc9191da7f37d9312e)

Walvoord, M.A., Striegl, R.G., Prudic, D.E., and Stonestrom, D.A., 2005, CO2 dynamics in the Amargosa DesertFluxes and isotopic speciation in a deep unsaturated zone: Water Resources Research, v. 41, no. 2., W02006, doi:10.1029/2004WR003599. 



\section{Appendix 1. Compilation of Borehole and Aquifer Data}



Appendix 1. Compilation of borehole and aquifer data.

[cm, centimeter; $\mathrm{m}$, meter; in, inch; ft, feet; \%, percent; ppm, parts per million; $\approx$, approximately equal to; >, greater than]

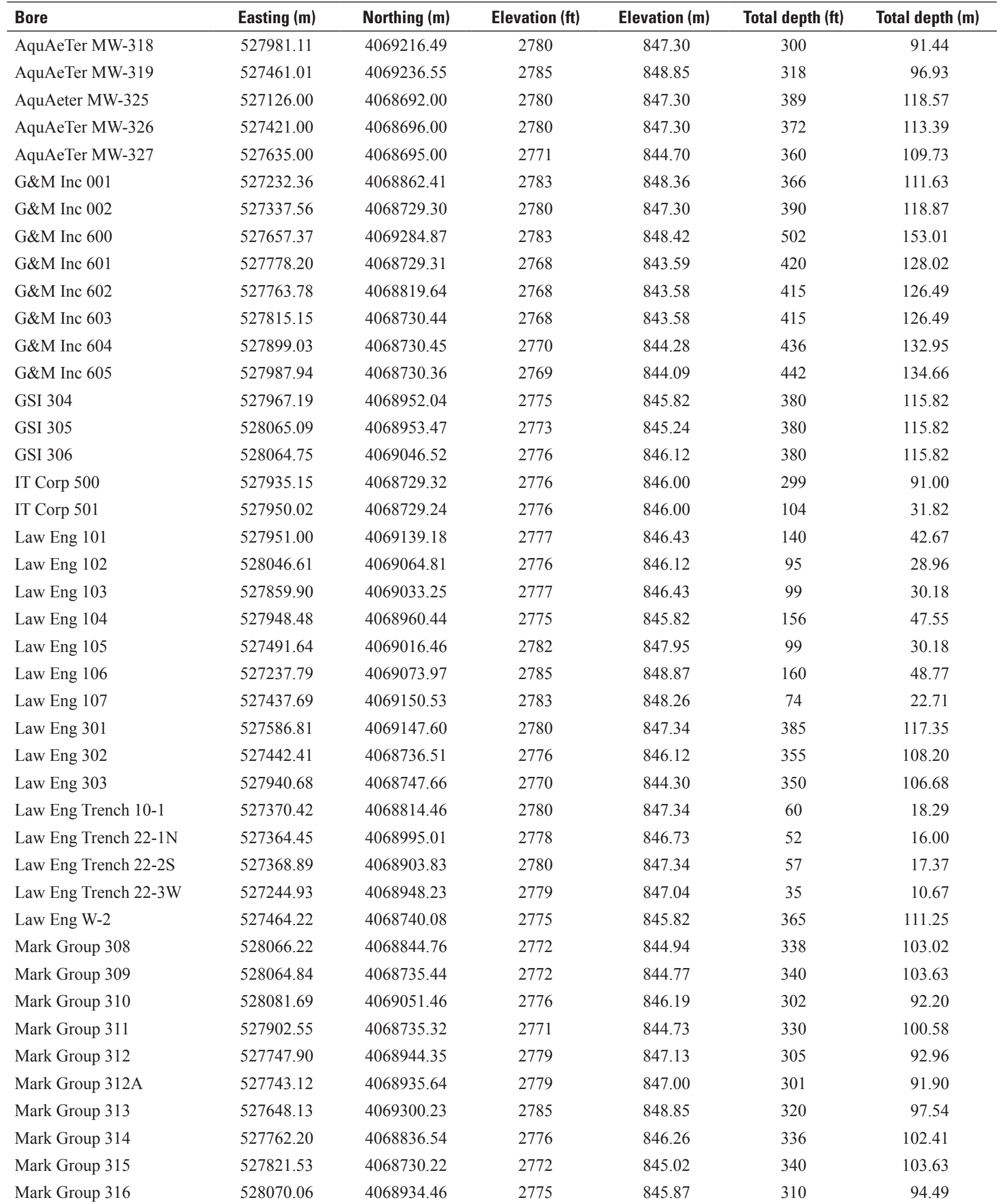




\section{Characterization of Geologic Deposits in the Vicinity of US Ecology, Amargosa Basin, Southern Nevada}

Appendix 1. Compilation of borehole and aquifer data.-Continued

[cm, centimeter; $\mathrm{m}$, meter; in, inch; $\mathrm{ft}$, feet; \%, percent; ppm, parts per million; $\approx$, approximately equal to; >, greater than]

\begin{tabular}{|c|c|c|c|c|c|c|}
\hline Bore & Easting (m) & Northing (m) & Elevation (ft) & Elevation (m) & Total depth (ft) & Total depth (m) \\
\hline Mark Group 317 & 527983.41 & 4068735.80 & 2771 & 844.75 & 340 & 103.63 \\
\hline Mark Group 400 & 527750.41 & 4068929.22 & 2777 & 846.58 & 537 & 163.68 \\
\hline Mark Group 402 & 527967.13 & 4069176.07 & 2779 & 846.92 & 163 & 49.83 \\
\hline Mark Group 402B & 527972.60 & 4069176.42 & 2779 & 846.92 & 37 & 11.43 \\
\hline Perc Est AFCA1 & 542415.00 & 4046485.00 & 2398 & 731.00 & 48 & 14.51 \\
\hline Perc Est AFCA2 & 542412.00 & 4046485.00 & 2398 & 731.00 & 39 & 12.04 \\
\hline Perc Est AFCA3 & 542273.00 & 4046225.00 & 2415 & 736.00 & 47 & 14.48 \\
\hline Perc Est AFCA4 & 542386.00 & 4045260.00 & 2388 & 728.00 & 33 & 10.06 \\
\hline Perk Est. ARAS1 & 528846.00 & 4062684.00 & 2648 & 807.00 & 153 & 46.49 \\
\hline Perk Est. ARRB1 & 521815.00 & 4072299.00 & 2907 & 886.00 & 159 & 48.50 \\
\hline Site Well 1961 & 527665.65 & 4068947.67 & 2780 & 847.50 & 575 & 175.26 \\
\hline US Ecology MW-315A & 527826.23 & 4068730.38 & 2779 & 847.00 & 321 & 97.99 \\
\hline US Ecology MW-323 & 527668.62 & 4068945.01 & 2779 & 847.00 & 298 & 90.98 \\
\hline USGS MR3 & 527389.20 & 4068719.60 & 2775 & 845.82 & 405 & 123.44 \\
\hline USGS No 1 & 527393.77 & 4068697.29 & 2770 & 844.30 & 574 & 175.00 \\
\hline USGS UZB-1 & 527257.93 & 4068633.22 & 2776 & 846.00 & 158 & 48.25 \\
\hline USGS UZB-2 & 527256.70 & 4068644.70 & 2776 & 846.00 & 376 & 114.66 \\
\hline
\end{tabular}


Appendix 1. Compilation of borehole and aquifer data.

[cm, centimeter; $\mathrm{m}$, meter; in, inch; $\mathrm{ft}$, feet; \%, percent; ppm, parts per million; $\approx$, approximately equal to; >, greater than]

\begin{tabular}{|c|c|c|c|c|}
\hline Bore & $\begin{array}{l}\text { Top } \\
\text { (m) }\end{array}$ & $\begin{array}{c}\text { Bottom } \\
\text { (m) }\end{array}$ & Simplified lithology & Driller's description \\
\hline Aquaeter MW-318 & 0.00 & 7.62 & sand, clay and gravel & $\begin{array}{l}\text { Pale yellowish brown (10YR6/2), well graded, fine-grained } \\
\text { silty sand, (60-70\%) with fine-grained gravel (20\%), } \\
\text { subrounded, dry. At } 15 \mathrm{ft} \text { gravel decrease to } 5 \% \text {. }\end{array}$ \\
\hline Aquaeter MW-318 & 7.62 & 10.67 & sand, clay and gravel & $\begin{array}{l}\text { Light brown to yellowish (5YR6/4), well graded, fine } \\
\text { gravel (50\%) with coarse to fine sand }(30 \%) \text { and silt } \\
(15 \%) \text {, fine-grained angular, dry. At } 30 \mathrm{ft} \text { brown to gray } \\
(5 \mathrm{YR} 5 / 2) \text {, well graded, fine-grained gravel }(50 \%) \text { with } \\
\text { coarse to fine-grained sand and silt }(40 \%) \text {, coarse- } \\
\text { grained gravel }(5 \%) \text {, dry }(40 \%) \text {. }\end{array}$ \\
\hline Aquaeter MW-318 & 10.67 & 12.19 & sand and gravel & $\begin{array}{l}\text { Brown to gray }(10 \text { YR } 6 / 2) \text {, fine and coarse sand }(60-70 \%) \\
\text { with fine-grained gravel. At } 40 \text { in change to moderate } \\
\text { yellowish brown }(10 \text { YR } 5 / 4) \text {. }\end{array}$ \\
\hline Aquaeter MW-318 & 12.19 & 24.38 & sand, clay and gravel & 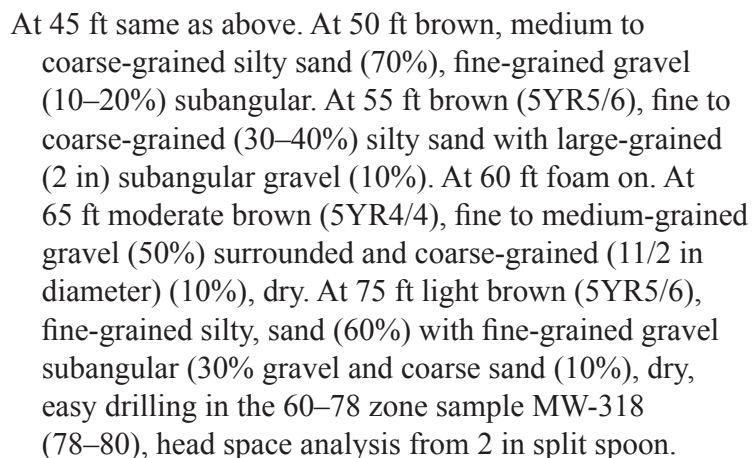 \\
\hline
\end{tabular}

Aquaeter MW-318 $\quad 24.38 \quad 25.91 \quad$ sand, clay and gravel $\quad$ Same as above. Foam on.

Aquaeter MW-318 $\quad 25.91 \quad 28.96 \quad$ sand and gravel

Light brown (5YR6/4), coarse-grained sand ( $\leq 2$ in) $(60 \%)$, coarse-grained sand $(30 \%)$ fines not present in cuttings, rig chatter heavy. At $90 \mathrm{ft}$ moderate brown (5YR3/4), poorly graded, fine-grained gravel (80-90\%), subangular with $10 \%$ coarse sand, cemented/hard layer and hard drilling.

Aquaeter MW-318

28.96

30.48

sand, clay and gravel

Aquaeter MW-318

30.48

32.00

sand and gravel

Aquaeter MW-318
32.00

33.53 sand, clay and gravel
Moderate-grained brown (5YR3/4), fine to medium silty sand $(80 \%)$ with fine-grained gravel $(15 \%)$, subangular and broken, and clay.

Moderate brown (5YR3/4), fine-grained gravel subangular (70\%) with coarse sand (20\%), and coarse-grained gravel (10\%) to 2 in.

Light olive brown (5YR5/6), medium to coarse-grained silty sand (60-70\%), fine gravel (30\%) subangular to subrounded. 
Appendix 1. Compilation of borehole and aquifer data.-Continued

[cm, centimeter; $\mathrm{m}$, meter; in, inch; ft, feet; \%, percent; ppm, parts per million; $\approx$, approximately equal to; $>$, greater than]

\begin{tabular}{|c|c|c|c|c|}
\hline Bore & $\begin{array}{l}\text { Top } \\
\text { (m) }\end{array}$ & $\begin{array}{l}\text { Bottom } \\
\text { (m) }\end{array}$ & Simplified lithology & Driller's description \\
\hline Aquaeter MW-318 & 33.53 & 35.05 & clay, sand and gravel & $\begin{array}{l}\text { Moderate brown (5YR3/4), cohesive sandy silt }(70 \%) \text { with } \\
\text { clay and (highly compact), fine-grained gravel }(10 \%) \text {. }\end{array}$ \\
\hline Aquaeter MW-318 & 35.05 & 36.58 & sand and gravel & $\begin{array}{l}\text { Gray-brown (5YR5/2), poorly graded, fine-grained gravel } \\
(90 \%) \text { subangular with coarse-grained sand }(10 \%) .\end{array}$ \\
\hline Aquaeter MW-318 & 36.58 & 48.77 & sand, clay and gravel & $\begin{array}{l}\text { Note, Foam drilling affects color of material. Continu- } \\
\text { ous rig chatter, gravel } 120-140 \mathrm{ft} \text {. At } 125 \mathrm{ft} \text { pale brown } \\
\text { (5YR5/2), coarse-grained sand (60\%) with silt }(10 \%), \\
\text { and subangular fine-grained gravel (30\%). At } 130 \mathrm{ft} \\
\text { same as above. At } 135 \mathrm{ft} \text { same as above. At } 140 \mathrm{ft} 5 \% \\
\text { medium gravel. Decrease to } 5 \% \text { fine-grained gravel. } \\
\text { At } 145 \mathrm{ft} \text { light brown (5YR6/4), poorly graded, fine to } \\
\text { medium-grained silty sand ( } 80-90 \%) \text { with fine-grained } \\
\text { gravel (10\%). At } 150 \mathrm{ft} \text { pale brown (5YR5/2), well } \\
\text { graded, medium to coarse-grained sand (70\%) and } \\
\text { silty fine-grained gravel (30\%). At } 155 \mathrm{ft} \text { pale brown } \\
\text { (5YR5/2), coarse-grained silty sand }(70 \%) \text { with fine- } \\
\text { grained subangular gravel (30\%). }\end{array}$ \\
\hline
\end{tabular}

Aquaeter MW-318

48.77

53.34

sand, clay and gravel

Aquaeter MW-318

53.34

60.96

sand, clay and gravel

Aquaeter MW-318

60.96

62.48

sand, clay and gravel

Aquaeter MW-318

62.48

68.58

sand, clay and gravel
Rig chatter, layer was very compact. 100 gallons of water/ foam added. At $165 \mathrm{ft}$ pale brown (5YR5/2) subangularsubrounded gravel. At $170 \mathrm{ft}$ same as above.

Pale brown (5YR5/2), silty and clayey coarse-grained sand $(80 \%)$ with poorly sorted fine-grained subangular gravel. Heavy rig chatter. At $180 \mathrm{ft}$ pale brown (5YR5/2), coarse-grained silty sand (60\%), and subangular finegrained gravel (40\%). At $185 \mathrm{ft}$ same as above. At $190 \mathrm{ft}$ same as above. At $195 \mathrm{ft}$ same as above.

Fine-grained (50\%) and coarse-grained (5-10\%) subrounded to subangular gravel with coarse-grained silty sand $(40 \%)$.

Pale brown (5YR5/2), well graded, coarse-grained silty sand $(70 \%)$ with subangular fine-grained gravel. At $210 \mathrm{ft}$ rig chatter. At $215 \mathrm{ft}$ same as above. At $220 \mathrm{ft}$ light brown (5YR5/6), well graded, coarse-grained sand $(60 \%)$ with fine-grained silty sand $(20 \%)$ and finegrained gravel subangular.

Moderate brown (5YR4/4), fine-grained subangular to subrounded gravel $(70 \%)$ with medium $(10 \%)$ to coarse-grained sand (20\%). At $230 \mathrm{ft}$ moderate brown (5YR4/4/), well graded, fine-grained subangular gravel $(60 \%)$ with medium to coarse-grained sand $(20 \%)$, and fine-grained silty sand (20\%). At $235 \mathrm{ft}$ light brown (5YR4/4), poorly graded, fine-grained gravel $(90 \%)$ with coarse-grained sand $(20 \%)$. 
Appendix 1. Compilation of borehole and aquifer data.-Continued

[cm, centimeter; m, meter; in, inch; ft, feet; \%, percent; ppm, parts per million; $\approx$, approximately equal to; $>$, greater than]

\begin{tabular}{|c|c|c|c|c|}
\hline Bore & $\begin{array}{l}\text { Top } \\
\text { (m) }\end{array}$ & $\begin{array}{c}\text { Bottom } \\
\text { (m) }\end{array}$ & Simplified lithology & Driller's description \\
\hline Aquaeter MW-318 & 73.15 & 85.34 & $\begin{array}{l}\text { sand, clay and trace } \\
\text { gravel }\end{array}$ & $\begin{array}{l}\text { Foam Off. At } 245 \mathrm{ft} \text { moderate brown }(5 \mathrm{YR} 3 / 4) \text {, well } \\
\text { graded, silty fine to coarse-grained sand }(70 \%) \text {, fine silty } \\
\text { sand }(30 \%) \text {, well graded with fine-grained subangular } \\
\text { gravel. Wet drilling fluids from moisture from above. At } \\
250 \mathrm{ft} \text { same as above. At } 255 \mathrm{ft} \text { same as above. } 260 \mathrm{ft} \\
\text { moderate brown (5YR3/4), silty fine to coarse-grained } \\
\text { sand }(80 \%) \text { with fine-grained, fine subangular gravel } \\
\text { damp/moist. Sample taken MW-318 (260-262 ft). At } \\
265 \mathrm{ft} \text { moderate brown ( } 5 \mathrm{YR} 4 / 4) \text {, hard, poorly graded, } \\
\text { fine- }(85 \%) \text { to medium- }(15 \%) \text { grained silty sand with } \\
\text { few fine-grained gravel fragments, very damp. At } 275 \mathrm{ft} \\
\text { medium-grained sand increase to } 30 \% \text { still mostly fines, } \\
\text { very similar lithology to where water was found in } \\
\text { MW-319. }\end{array}$ \\
\hline
\end{tabular}

Aquaeter MW-318 $\quad 85.34 \quad 91.44 \quad$ sand and clay

Aquaeter MW-319

Aquaeter MW-319

Aquaeter MW-319

6.10

9.14

sand, clay and gravel

Aquaeter MW-319

9.14

12.19

sand, clay and gravel

Aquaeter MW-319

4.57 sand, clay and gravel

6.10 sand, clay and gravel
Brown, well graded, coarse subangular gravel ( $\leq 3$ in size) with subrounded fine gravel, sand and silt, dry.

Brown, fine to coarse subangular gravel (40\%) with fine to coarse-grained sand (30\%) and silt, dry. Rig chatter. At $25 \mathrm{ft}$ increase fine sand and silt to $40 \%$.

Brown, fine-grained sand and silt (60\%) with fine subangular gravel, dry. At $40 \mathrm{ft}$ heavy rig chatter, lost air circulation on rig with fine sand cave in.

Foam Drilling. Brown, well graded, subangular fine gravel $(60 \%)$ with sand, dry. At $45 \mathrm{ft}$ brown, fine to coarse gravel $(50 \%)(\leq 1$ in) with coarse sand $(30 \%)$, dry. At $50 \mathrm{ft}$ minor rig chatter. Driller indicates formation is tightly packed but not cemented. At $55 \mathrm{ft}$ less borehole cave-in easier drilling. At $60 \mathrm{ft}$ dark brown, fine gravel, subrounded with coarse sand, dry. 
Appendix 1. Compilation of borehole and aquifer data.-Continued

[cm, centimeter; $\mathrm{m}$, meter; in, inch; ft, feet; \%, percent; ppm, parts per million; $\approx$, approximately equal to; >, greater than]

\begin{tabular}{|c|c|c|c|c|}
\hline Bore & $\begin{array}{l}\text { Top } \\
\text { (m) }\end{array}$ & $\begin{array}{l}\text { Bottom } \\
\text { (m) }\end{array}$ & Simplified lithology & Driller's description \\
\hline Aquaeter MW-319 & 19.81 & 24.38 & sand, clay and gravel & $\begin{array}{l}\text { Dark brown, fine-grained silty sand }(60 \%) \text { with gray to } \\
\text { brown subangular fine gravel }(20 \%) \text {, dry. }\end{array}$ \\
\hline Aquaeter MW-319 & 24.38 & 25.91 & sand, clay and gravel & Same as above. \\
\hline Aquaeter MW-319 & 25.91 & 36.58 & sand and gravel & $\begin{array}{l}\text { Brown, well graded, fine gravel }(60 \%) \text { subangular to an- } \\
\text { gular with very coarse sand, dry. At } 90 \mathrm{ft} \text { brown, coarse } \\
\text { angular to subangular (to } 2 \text { in) gravel with coarse angu- } \\
\text { lar sand, dry. At } 95 \mathrm{ft} \text { moderate brown (5YR4/4), fine } \\
\text { gravel }(60 \%) \text {, subangular with very coarse sand }(30 \%) \\
\text { and minor gravel ( } \leq 2 \text { in) and fine-grained sand and silt, } \\
\text { dry. At } 100 \% \text { light brown ( } 5 \text { YR } 5 / 6) \text {, well graded, coarse } \\
\text { subangular gravel ( } \leq 2 \mathrm{in}) \text { with fine-grained silty sand } \\
(15-20 \%) \text {, dry. At } 105 \mathrm{ft} \text { rig chatter gravel appears to be } \\
\text { broken. At } 110 \mathrm{ft} \text { harder drilling, well graded material } \\
\text { angular and broken. At } 115 \mathrm{ft} \text { darker brown }(5 \mathrm{YR} 3 / 4) \text {, } \\
\text { fine and coarse gravel, }(70 \%)(1 / 2-1 \text { in size) with very } \\
\text { coarse sand, dry. }\end{array}$ \\
\hline
\end{tabular}

$\begin{array}{llll}\text { Aquaeter MW-319 } & 36.58 & 42.67 \quad \text { sand, clay and gravel }\end{array}$

Aquaeter MW-319

Aquaeter MW-319

45.72

48.77

sand, clay and gravel

Aquaeter MW-319

48.77

59.44

sand, clay and gravel
60.96 sand and gravel
Moderate brown (5YR4/4), well graded fine gravel (60-70\% with coarse sand and some silt, subangular, dry. At $125 \mathrm{ft}$ larger gravel, same coarse gravel. At $130 \mathrm{ft}$ increased fine-grained sand and silt to $10 \%$, gravel is rounded. At $135 \mathrm{ft}$ color is impacted by wetness (foam). Rig chatter and hard drilling 136-138 ft.

Light brown (5YR5/6), coarse-grained sand with silt (70\%) with fine gravel (20\%), dry. At $145 \mathrm{ft}$ color change to moderate brown (5YR4/4).

Moderate brown (5YR4/4), well graded, coarse to mediumgrained sand with fine gravel subangular and broken and silt, dry. At $155 \mathrm{ft}$ moderate brown (5YR4/4), medium to coarse-grained sand with silt, and fine subrounded gravel, dry.

Light brown (5YR5/6), medium to coarse-grained sand and silt (60\%) with fine gravel, dry. At $170 \mathrm{ft}$ rig chatter at $170 \mathrm{ft}$, increase fine gravel to $30 \%$. At $175 \mathrm{ft}$ heavy rig chatter at $175 \mathrm{ft}$. At $180 \mathrm{ft}$ lighter brown (5YR5/6), poorly graded, coarse sand and silt (80\%), fine angular gravel, dry. At $185 \mathrm{ft}$ moderate brown (5YR4/4), coarsegrained sand with silt (60\%) and increased fine gravel $(30 \%)$, dry.

At $195 \mathrm{ft}$ moderate brown (5YR4/4), well graded, coarsegrained sand with fine subangular gravel. Hard drilling $195-215 \mathrm{ft}$. 
Appendix 1. Compilation of borehole and aquifer data.-Continued

[cm, centimeter; m, meter; in, inch; ft, feet; \%, percent; ppm, parts per million; $\approx$, approximately equal to; $>$, greater than]

\begin{tabular}{|c|c|c|c|c|}
\hline Bore & $\begin{array}{l}\text { Top } \\
\text { (m) }\end{array}$ & $\begin{array}{c}\text { Bottom } \\
\text { (m) }\end{array}$ & Simplified lithology & Driller's description \\
\hline Aquaeter MW-319 & 60.96 & 64.01 & sand, clay and gravel & $\begin{array}{l}\text { Pale brown (5YR5/2), and gray coarse-grained sand and } \\
\text { silt ( } 70 \% \text { ) with subangular broken fine gravel. Hard } \\
\text { drilling-heavy chatter } 200-205 \mathrm{ft} \text {. At } 205 \mathrm{ft} \text { moderate } \\
\text { brown (5YR4/4), coarse sand and silt, increase fine } \\
\text { broken and subangular gravel }(25-30 \%) \text {. }\end{array}$ \\
\hline Aquaeter MW-319 & 65.53 & 67.06 & sand, clay and gravel & $\begin{array}{l}\text { Moderate brown (5YR4/4), fine gravel ( } 60 \%) \text {, angular } \\
\text { and broken with coarse-grained sand and minor silt and } \\
\text { clay, dry. }\end{array}$ \\
\hline Aquaeter MW-319 & 70.10 & 73.15 & sand, clay and gravel & $\begin{array}{l}\text { Moderate brown }(5 \mathrm{YR} 4 / 4) \text {, fine to coarse }(1 \mathrm{in}) \text { subangular } \\
\text { gravel }(60 \%) \text { with coarse-grained sand }(30 \%) \text { and minor } \\
\text { silt and clay, dry. At } 235 \mathrm{ft} \text { dark brown }(5 \mathrm{YR} 3 / 4) \text {, well } \\
\text { graded, fine to coarse gravel }(60 \%) \text { with coarse-grained } \\
\text { sand }(20 \%) \text { and fine-grained sand and silt }(20 \%) \text {, angular } \\
\text { to subangular. Drilling paused to install } 8 \text { in casing down } \\
\text { to } 240 \mathrm{ft} \text {. }\end{array}$ \\
\hline Aquaeter MW-319 & 85.34 & 92.96 & sand, clay and gravel & $\begin{array}{l}\text { Color change to pale brown (5YR/2), water level checked } \\
\text { but not detected. At } 285 \mathrm{ft} \text { increase silt to } 40-50 \% \text {, los- } \\
\text { ing circulation in formation, no cuttings return. At } 290 \mathrm{ft} \\
\text { circulation reestablished, formation had caved on top of } \\
\text { drill bit, drilling slowly to maintain circulation. At } 300 \mathrm{ft} \\
\text { pale brown (5YR } 5 / 2) \text {, well graded, coarse to medium- } \\
\text { grained silty sand with fine gravel }(5-10 \%) \text {. Gravel } \\
\text { above may have been caved material. }\end{array}$ \\
\hline
\end{tabular}


Appendix 1. Compilation of borehole and aquifer data.-Continued

[cm, centimeter; $\mathrm{m}$, meter; in, inch; ft, feet; \%, percent; ppm, parts per million; $\approx$, approximately equal to; $>$, greater than]

\begin{tabular}{|c|c|c|c|c|}
\hline Bore & $\begin{array}{l}\text { Top } \\
\text { (m) }\end{array}$ & $\begin{array}{c}\text { Bottom } \\
\text { (m) }\end{array}$ & Simplified lithology & Driller's description \\
\hline Aquaeter MW-319 & 92.66 & 96.93 & sand and clay & $\begin{array}{l}\text { Gray-brown, medium to coarse-grained sand }(60 \%) \text { with } \\
\text { silt and fine sand ( } 40 \%) \text {, dry. At } 310 \mathrm{ft} \text { harder layer en- } \\
\text { countered, no cuttings returned, drilling is advancing but } \\
\text { not returning cuttings due to cave in above bit. Based } \\
\text { on slow advance of borehole this layer appears to be } \\
\text { relatively hard. At } 315 \mathrm{ft} \text { no return. Bottom at } 318 \mathrm{ft} \text {. }\end{array}$ \\
\hline
\end{tabular}

Aquaeter MW-325

0.00

6.10

sand, clay and gravel

Aquaeter MW-325

6.10

9.14

sand, clay and gravel

sand, clay and gravel

Aquaeter MW-325

12.19

18.29

sand, clay and gravel

Aquaeter MW-325

sand, clay and gravel

Aquaeter MW-325

24.38

36.58

sand and clay
Brown, well graded, coarse to medium subrounded to subangular sand (50-60\%) with large gravel $\leq 2$ in, minor silt, dry. At $5 \mathrm{ft}$ same as above. At $10 \mathrm{ft}$ same as above. At $15 \mathrm{ft}$ same as above, gravel is smaller and subangular.

Brown, poorly graded, fine to medium-grained sand and silt (70\%) with fine subangular gravel, dry. At $25 \mathrm{ft}$ same as above.

Brown, well graded, coarse and fine subangular gravel with medium-grained sand and silt, dry sample collected at $30 \mathrm{ft}$ from cuttings for chemical analysis. At $35 \mathrm{ft}$ brown, well graded, fine subrounded to subangular gravel with fine to medium-grained sand and silt, dry.

Brown, well graded, fine subangular gravel with coarsegrained sand, less fine to medium-grained sand and silt than above, dry. At $45 \mathrm{ft}$ same as above, switch to drill drive. At $50 \mathrm{ft}$ same as above gravel is slightly larger than above. Sand is of all sizes. At $55 \mathrm{ft}$ same, finegrained subangular gravel.

Brown, well graded, fine to coarse-grained sand with fine subangular gravel and silt, dry. At $65 \mathrm{ft}$ same as above, slow drilling. At $70 \mathrm{ft}$ same as above, minor fine gravel. At $75 \mathrm{ft}$ same as above, sand and silt (70-80\%), fine subangular gravel.

Same as above as above. At $85 \mathrm{ft}$ gray, well graded, fine broken gravel with coarse-grained sand and silt, dry. At $90 \mathrm{ft}$ same as above, sand fine to medium-grained, dry, increase in speed of drilling, casing parted at $96 \mathrm{ft}$, open hole drilling. At $95 \mathrm{ft}$ same as above, gravel is slightly larger, rig chatter at $98.0 \mathrm{ft}$. At $100 \mathrm{ft}$ brown, well graded, fine subangular, broken gravel $(\leq 1 / 2$ in) with coarse-grained sand, minor silt, dry. At $105 \mathrm{ft}$ same as above. At $110 \mathrm{ft}$ same as above. At $115 \mathrm{ft}$ same as above, rig chatter. At $120 \mathrm{ft}$ same as above. 
Appendix 1. Compilation of borehole and aquifer data.-Continued

[cm, centimeter; m, meter; in, inch; ft, feet; \%, percent; ppm, parts per million; $\approx$, approximately equal to; $>$, greater than]

\begin{tabular}{|c|c|c|c|c|}
\hline Bore & $\begin{array}{l}\text { Top } \\
\text { (m) }\end{array}$ & $\begin{array}{c}\text { Bottom } \\
\text { (m) }\end{array}$ & Simplified lithology & Driller's description \\
\hline Aquaeter MW-325 & 36.58 & 48.77 & sand and clay & $\begin{array}{l}\text { Same as above as above. At } 125 \mathrm{ft} \text { same as above as above, } \\
\text { rig chatter. At } 130 \mathrm{ft} \text { brown, well graded, fine gravel with } \\
\text { fine-grained sand and silt ( } 40-50 \%) \text { and minor coarse } \\
\text { gravel fragments, dry. Easier drilling. At } 135 \mathrm{ft} \text { same as } \\
\text { above. At } 140 \mathrm{ft} \text { same as above. At } 145 \mathrm{ft} \text { same as above, } \\
\text { east drilling. At } 150 \mathrm{ft} \text { same as above. At } 155 \mathrm{ft} \text { same as } \\
\text { above. At } 160 \mathrm{ft} \text { physical analyses sample. }\end{array}$ \\
\hline
\end{tabular}

$\begin{array}{lll}\text { Aquaeter MW-325 } & 48.77 \quad 50.29 \quad \text { sand, clay and gravel }\end{array}$

Aquaeter MW-325

Aquaeter MW-325

Aquaeter MW-325

Aquaeter MW-325

62.48

67.06

clay, sand and gravel

Aquaeter MW-325

67.06

70.10

sand, clay and gravel

Aquaeter MW-325

70.10
73.15
Brown (5YR6), well graded, fine-grained subangular gravel (50\%), fragments with fine to coarse-grained sand $(40 \%)$, and silt (10\%), dry.

Brown (5YR6), well graded, fine to medium-grained sand $(60 \%)$ with fine subangular gravel $(20 \%)$ and silt $(20 \%)$, dry, easy drilling. At $170 \mathrm{ft}$ same as above, sand (50\%), gravel (30\%), silt (20\%), dry, easy drilling.

Brown (5YR6), well graded, subangular fine gravel (70\%) with fine-grained sand (20\%) and silt (10\%), dry. At $180 \mathrm{ft} \mathrm{same}$, gravel (50\%), sand (40\%), silt (10\%).

Brown (5YR5), well graded, fine to coarse-grained sand (70\%) with subangular gravel (30\%), dry. At $190 \mathrm{ft}$ same as above, sand $(60 \%)$, gravel $(40 \%)$. At $195 \mathrm{ft}$ same as above.

Brown (5YR5), well graded, fine to coarse-grained gravel $(70 \%)$ with fine-grained sand (20\%) and clay (10\%), slight moisture.

Brown (5YR5), well graded, fine to coarse-grained sand $(50 \%)$ with fine-grained subangular gravel $(40 \%)$ and silt (10\%, dry. At $210 \mathrm{ft}$ same as above. At $215 \mathrm{ft}$ same as above, sand (50\%, gravel (30\%), silt (23\%), dry more dust, dry.

Brown, well graded, fine subangular gravel (50\%) with fine to coarse-grained sand (30\%) and silt (20\%), dry. At $225 \mathrm{ft}$ same as above, slight moisture.

Brown (5YR6), well graded, fine to coarse-grained sand $(60 \%)$ with fine subangular gravel $(40 \%)$, slight moisture. At $235 \mathrm{ft}$ same as above, sand (60\%), gravel (30\%), silt $(10 \%)$. 
Appendix 1. Compilation of borehole and aquifer data.-Continued

[cm, centimeter; $\mathrm{m}$, meter; in, inch; ft, feet; \%, percent; ppm, parts per million; $\approx$, approximately equal to; $>$, greater than]

\begin{tabular}{|c|c|c|c|c|}
\hline Bore & $\begin{array}{l}\text { Top } \\
\text { (m) }\end{array}$ & $\begin{array}{l}\text { Bottom } \\
\text { (m) }\end{array}$ & Simplified lithology & Driller's description \\
\hline Aquaeter MW-325 & 73.15 & 80.77 & sand, clay and gravel & $\begin{array}{l}\text { Brown (5YR6), well graded, fine to coarse-grained sand } \\
(60 \%) \text { with gravel }(30 \%) \text {, and silt (10\%), slight moisture } \\
\text { in sample bag. At } 245 \mathrm{ft} \text { brown (5YR5), well graded, } \\
\text { fine to medium-grained sand ( } 60 \%) \text { with fine-grained } \\
\text { subangular gravel }(20 \%) \text {, and silt ( } 20 \%) \text {, dry. At } 250 \mathrm{ft} \\
\text { same as above. At } 255 \mathrm{ft} \text { same as above. At } 260 \mathrm{ft} \text { same } \\
\text { as above, discharge hose plugged, logged from cuttings } \\
\text { at well head. }\end{array}$ \\
\hline
\end{tabular}

Aquaeter MW-325

Aquaeter MW-325

Aquaeter MW-325

Aquaeter MW-325

Aquaeter MW-325

Aquaeter MW-325

Aquaeter MW-325

Aquaeter MW-325
80.77

83.82

85.34

sand, clay and gravel

83.82 sand, clay and gravel

$85.34 \quad 88.39 \quad$ sand, clay and gravel

88.39

89.92

sand, clay and trace gravel

89.92

94.49 sand, clay and trace
gravel

$94.49 \quad 96.01 \quad$ clay, sand and gravel

$96.01 \quad 97.54 \quad$ clay, sand and gravel

97.54
99.06
Brown (5YR6), well graded, fine subangular gravel (50\%) with fine to medium-grained sand (40\%) and silt (10\%), dry. Rig chatter. At $270 \mathrm{ft}$ same as above.

Gray-brown (5YR8), hard, fine to coarse-grained sand $(60 \%)$ with fine subangular gravel $(20 \%)$ and silt $(20 \%)$, dry, cemented. At $280 \mathrm{ft}$ drill is slower, finer cuttings more dust.

Gray-brown (5YR8), hard, fine to coarse-grained sand (70\%) with fine subangular gravel (10\%) and silt (20\%), dry, rig chatter. At $285 \mathrm{ft}$ same as above, dusty with heavy chatter.

Brown (10YR7), fine to coarse-grained silty sand (50\%) with gravel (10\%), dry, easier drilling.

Brown (10YR7), well graded, fine to coarse-grained sand silt (60\%) with fine subangular gravel (5\%), dry. At $300 \mathrm{ft}$ same as above, silt (60\%), sand (40\%), no gravel, dry. At $305 \mathrm{ft}$ same as above.

Brown (5YR6), hard, fine to coarse-grained sand (50\%) with silt (40\%), and fine gravel (10\%), dry heavy rig chatter.

Brown (5YR6), fine to coarse-grained sandy silt (50\%) with fine subangular gravel $(10 \%)$, dry.

Brown (5YR6), well graded, fine to coarse-grained sandy (30\%) gravel, subangular with silt (20\%), dry, rig chatter. 
Appendix 1. Compilation of borehole and aquifer data.-Continued

[cm, centimeter; m, meter; in, inch; ft, feet; \%, percent; ppm, parts per million; $\approx$, approximately equal to; $>$, greater than]

\begin{tabular}{|c|c|c|c|c|}
\hline Bore & $\begin{array}{l}\text { Top } \\
\text { (m) }\end{array}$ & $\begin{array}{c}\text { Bottom } \\
\text { (m) }\end{array}$ & Simplified lithology & Driller's description \\
\hline Aquaeter MW-325 & 99.06 & 109.73 & $\begin{array}{l}\text { sand, clay and trace } \\
\text { gravel }\end{array}$ & $\begin{array}{l}\text { Brown (5YR6), well graded, fine to coarse-grained sand } \\
\text { (50\% with silt ( } 45 \%) \text { and minor gravel ( } 5 \%) \text {, dry, rig } \\
\text { chatter. Same as above, rig chattering but cuttings are } \\
\text { ground fine. At } 330 \mathrm{ft} \text { same as above. At } 335 \mathrm{ft} \text { same as } \\
\text { above. Silt ( } 50 \%) \text {, sand ( } 45 \%) \text {, gravel ( } 5 \%) \text {. At } 340 \mathrm{ft} \\
\text { same as above, silt ( } 60 \%) \text {, sand ( } 35 \%) \text {, gravel }(5 \%) \text {. } \\
\text { Heavy chatter-large gravel being returned in cuttings } \\
\text { hard drilling. At } 345 \mathrm{ft} \text { same as above, silt ( } 70 \%) \text {, sand } \\
\text { (25\%), slight moisture in silt. Lots of gravel being } \\
\text { returned from borehole. At } 350 \mathrm{ft} \text { same as above, very } \\
\text { hard drilling at } 349 \mathrm{ft} \text {. Rig chattering, slight moisture } \\
\text { in silt hard drilling, gravel in cuttings is fine grain to } \\
\text { medium. At } 355 \mathrm{ft} \text { broke through hard layer at } 355 \mathrm{ft} \text { silt } \\
(60 \%) \text {, sand }(40 \%) \text {, slight moisture. }\end{array}$ \\
\hline
\end{tabular}

Aquaeter MW-325 $\quad 109.73 \quad 118.57 \quad$ sand, clay and trace gravel

Aquaeter MW-325

118.57

118.87

sand, clay and trace gravel

Aquaeter MW-325

118.87

121.92

sand and gravel

Aquaeter MW-326

0.00

12.19

sand and gravel
Brown, well graded, fine to medium-grained sandy (40\%) silt with clay ( $60 \%$ silt and clay), damp, no water. At $365 \mathrm{ft}$ same as above, damp. Hard layer at $368 \mathrm{ft}$. At $370 \mathrm{ft}$ same as above, rig chattering, damp in fine portion. 1/4-3/4 in gravel was returned in drill cuttings due to use of foam in 10 in borehole gravel portion of lithology was not fully returned during 8- boring. At $375 \mathrm{ft}$ easier drilling. Same as above, increased clay more fines ( $80 \%)$ fine to medium-grained sand $(20 \%)$, increased moisture in fines but no water observed. At $380 \mathrm{ft}$ same as above, damp. At $385 \mathrm{ft}$ same as above, damp, hard drilling. Same as above, bottom at $388.5 \mathrm{ft}$.

Split spoon sample 389-391 ft. At 390 brown, fine to medium-grained clayey sand with $10 \%$ fine gravel, wet.

From 335-389 ft, gravel portion of lithology not represented during pilot hole (drilled day). Use of foam for 10 in borehole recovered fine to coarse gravel during reaming operation.

Tan, well graded, subangular to subrounded fine gravel with fine to coarse-grained sand, dry. At $10 \mathrm{ft}$ same as above. At $15 \mathrm{ft}$ same as above, increase gravel size to 1 in gravel. At $20 \mathrm{ft}$ tan, well graded, subangular to subrounded fine gravel with fine to mostly coarse-grained sand, dry. At $25 \mathrm{ft}$ tan, well graded, fine-grained gravel with very coarse sand with some medium sand, dry. At $30 \mathrm{ft}$ Tan, well graded, subangular fine to coarse gravel with coarse sand, dry. At $35 \mathrm{ft}$ same as above.

Tan, well graded, fine gravel with coarse to mediumgrained sand, dry. 
Appendix 1. Compilation of borehole and aquifer data.-Continued

[cm, centimeter; $\mathrm{m}$, meter; in, inch; ft, feet; \%, percent; ppm, parts per million; $\approx$, approximately equal to; $>$, greater than]

\begin{tabular}{ccccc}
\hline Bore & $\begin{array}{c}\text { Top } \\
(\mathbf{m})\end{array}$ & $\begin{array}{c}\text { Bottom } \\
(\mathbf{m})\end{array}$ & Simplified lithology & Driller's description \\
\hline Aquaeter MW-326 & 13.72 & 19.81 & sand and clay & $\begin{array}{c}\text { Tan, well grade, fine to coarse-grained sand, with } 30-40 \% \\
\text { silt, dry. At } 50 \mathrm{ft} \text { same as above with fine gravel. At } 55 \mathrm{ft} \\
\text { same as above, larger gravel not present in cuttings. } \\
\end{array}$ \\
& & & $\begin{array}{l}\text { Suspected cave-in and rig inability to return larger frag- } \\
\text { ments to surface. Foam drilling began at } \approx 58 \mathrm{ft} \text {. At } 60 \mathrm{ft}\end{array}$ \\
& & & same as above, increase gravel size to 1 in.
\end{tabular}

Aquaeter MW-326

19.81

24.38

sand and gravel

Aquaeter MW-326

Aquaeter MW-326

Aquaeter MW-326

36.58

38.10

sand and gravel

Aquaeter MW-326

Aquaeter MW-326

44.20

48.77

sand, clay and gravel

Aquaeter MW-326

Aquaeter MW-326

51.82

54.86

sand and gravel

Aquaeter MW-326

$54.86 \quad 57.91 \quad$ sand and gravel

Brown, subangular to subrounded fine gravel, some pieces $\leq 1$ in with sand, dry. At $70 \mathrm{ft}$ same as above, foam off, no lift of gravel. At $75 \mathrm{ft}$ brown, well graded, subangular fine gravel with coarse-grained sand.

Brown, well graded, subrounded to subangular, coarsegrained sand, dry. At $85 \mathrm{ft}$ same as above.

Brown, well graded, subangular to subrounded fine to coarse gravel with very coarse-grained sand, dry. At $95 \mathrm{ft}$ same as above. At $100 \mathrm{ft}$ brown, subangular fine gravel, some pieces $\leq 1$ in with coarse-grained sand, dry. At $110 \mathrm{ft} \mathrm{same}$ as above. At $115 \mathrm{ft}$ same as above.

Brown, coarse-grained sand with subangular gravel, dry. At $125 \mathrm{ft}$ brown, well graded, subangular fine gravel $1 / 4-1 / 2$ in with sand, dry.

Brown, well graded, subangular fine gravel $1 / 4-1 / 2$ in with sand, dry. At $130 \mathrm{ft}$ well graded, subangular fine gravel with coarse-grained sand, dry. At $135 \mathrm{ft}$ same as above. At $140 \mathrm{ft}$ same as above.

Brown, coarse-grained sand with subangular fine gravel, dry. At $150 \mathrm{ft}$ same as above. At $155 \mathrm{ft}$ same as above. Soils show high cohesion with possible presence of silt/ fine sand. Drilling foam makes it hard to differentiate grain-sizes.

Brown, fine to coarse subangular gravel with coarsegrained sand, dry. At $165 \mathrm{ft}$ same as above.

Brown, well graded, coarse-grained sand with fine subangular gravel. At $175 \mathrm{ft}$ same as above, slightly larger gravel.

Brown, poorly graded, coarse-grained sand with 5-10\% gravel, dry. At $185 \mathrm{ft}$ same as above. 
Appendix 1. Compilation of borehole and aquifer data.-Continued

[cm, centimeter; m, meter; in, inch; ft, feet; \%, percent; ppm, parts per million; $\approx$, approximately equal to; $>$, greater than]

\begin{tabular}{|c|c|c|c|c|}
\hline Bore & $\begin{array}{l}\text { Top } \\
\text { (m) }\end{array}$ & $\begin{array}{c}\text { Bottom } \\
\text { (m) }\end{array}$ & Simplified lithology & Driller's description \\
\hline Aquaeter MW-326 & 57.91 & 60.96 & sand and gravel & $\begin{array}{l}\text { Brown, well graded, fine to coarse gravel with subangular } \\
\text { coarse-grained sand, dry. At } 195 \mathrm{ft} \text { brown, fine subangu } \\
\text { lar gravel with coarse-grained sand, dry. }\end{array}$ \\
\hline Aquaeter MW-326 & 60.96 & 73.15 & sand and gravel & $\begin{array}{l}\text { Same as above. At } 205 \mathrm{ft} \text { same as above, gravel increased } \\
\text { size slightly. At } 210 \mathrm{ft} \text { same as above. At } 215 \mathrm{ft} \text { same } \\
\text { as above. At } 220 \mathrm{ft} \text { same as above, rig chatter at } 220 \mathrm{ft} \text {. } \\
\text { At } 225 \mathrm{ft} \text { same as above, rig chatter. At } 230 \mathrm{ft} \text { same as } \\
\text { above, rig chatter. At } 235 \mathrm{ft} \text { same as above. }\end{array}$ \\
\hline Aquaeter MW-326 & 73.15 & 85.34 & sand and gravel & $\begin{array}{l}\text { Same as above, rig chatter, gravel is broken and angular. } \\
\text { At } 245 \mathrm{ft} \text { same as above. At } 250 \mathrm{ft} \text { same as above, rig } \\
\text { chatter. At } 255 \mathrm{ft} \text { same as above, rig chatter. At } 260 \mathrm{ft} \\
\text { same as above. At } 265 \mathrm{ft} \text { same as above. At } 270 \mathrm{ft} \\
\text { same as above. At } 275 \mathrm{ft} \text { same as above water added } \\
\approx 160 \text { gallons. }\end{array}$ \\
\hline
\end{tabular}

Aquaeter MW-326

Aquaeter MW-326

Aquaeter MW-326

Aquaeter MW-326

Aquaeter MW-326

Aquaeter MW-327

Aquaeter MW-327
109.73

112.78

sand, clay and gravel

85.34

91.44

sand and gravel

91.44

97.54

sand, clay and gravel

97.54

109.73

sand, clay and gravel

112.78

113.39

sand, clay and gravel

0.00

6.10

sand and gravel

6.10

7.62

sand and gravel
Same as above. At $285 \mathrm{ft} \mathrm{same} \mathrm{as} \mathrm{above,} \mathrm{harder} \mathrm{drilling}$ 275-285 ft driller suspects cemented formation. At $290 \mathrm{ft}$ same as above. At $295 \mathrm{ft}$ same as above.

Brown, fine to medium-grained clayey sand with minor fine subangular gravel, cemented, dry. At $305 \mathrm{ft}$ same as above, rig chatter. At $310 \mathrm{ft}$ same as above, rig chatter. At $315 \mathrm{ft}$ same as above, rig chatter and hard-drilling.

Same as above. At $325 \mathrm{ft}$ same as above. At $330 \mathrm{ft}$ same as above. At $335 \mathrm{ft}$ same as above. At $340 \mathrm{ft}$ same as above. At $345 \mathrm{ft}$ same as above. At $350 \mathrm{ft}$ same as above. At $355 \mathrm{ft}$ same as above. Static water level at $356 \mathrm{ft}$, water added $\approx 50$ gallons.

Same as above, cemented layer. At $365 \mathrm{ft}$ brown, fine to coarse-grained silty sand with minor clay, wet, 366-370 ft rig chatter stopped, easier drilling.

Bottom At $372 \mathrm{ft}$.

Brown, well graded, subangular to subrounded gravel with medium to coarse-grained sand, dry. At $10 \mathrm{ft}$ same as above, increase in medium to coarse-grained sand, dry. At $15 \mathrm{ft}$ same as above.

Brown, poorly graded, medium to coarse-grained sand $(90 \%)$ with some fine gravel, dry. 
Appendix 1. Compilation of borehole and aquifer data.-Continued

[cm, centimeter; $\mathrm{m}$, meter; in, inch; ft, feet; \%, percent; ppm, parts per million; $\approx$, approximately equal to; $>$, greater than]

\begin{tabular}{|c|c|c|c|c|}
\hline Bore & $\begin{array}{l}\text { Top } \\
\text { (m) }\end{array}$ & $\begin{array}{c}\text { Bottom } \\
\text { (m) }\end{array}$ & Simplified lithology & Driller's description \\
\hline Aquaeter MW-327 & 7.62 & 12.19 & sand and gravel & $\begin{array}{l}\text { Brown, well graded, fine to coarse gravel with coarse to } \\
\text { medium-grained sand subangular, dry. At } 30 \mathrm{ft} \text { increase } \\
\text { gravel size to } 2 \text { in, subangular size with sand, dry. At } \\
35 \mathrm{ft} \text { same as above. }\end{array}$ \\
\hline Aquaeter MW-327 & 12.19 & 24.38 & sand and gravel & $\begin{array}{l}\text { Same as above with gravel } \leq 11 / 4 \text { in size. At } 45 \mathrm{ft} \text { no return } \\
\text { of larger gravel to surface. Rig does not have enough } \\
\text { lift because air flow restriction by filter on compres- } \\
\text { sor, dry. At } 50 \mathrm{ft} \text { no return, change to drill and drive. At } \\
55 \mathrm{ft} \text { brown, well graded, coarse gravel with coarse to } \\
\text { medium-grained sand, subangular to subrounded, dry. } \\
\text { At } 60 \mathrm{ft} \text {, increased silt and sand, dry. At } 65 \mathrm{ft} \text { same as } \\
\text { above, open hole drilling. At } 70 \mathrm{ft} \text { same as above, open } \\
\text { hole drilling. At } 75 \mathrm{ft} \text { brown, well graded, subangular } \\
\text { to subrounded fine to coarse gravel } \leq 1 \text { in with fine to } \\
\text { coarse-grained silty sand, dry. }\end{array}$ \\
\hline Aquaeter MW-327 & 24.38 & 36.58 & sand and gravel & $\begin{array}{l}\text { Same as above with increased gravel size, } \leq 11 / 2 \mathrm{in} \text {. At } \\
85 \mathrm{ft} \text { brown, well graded, fine subrounded gravel with } \\
\text { coarse-grained, silty sand, subrounded. Add in external } \\
\text { air compressor for supplemental air. At } 90 \mathrm{ft} \text { same as } \\
\text { above with rig chatter at } \approx 90 \mathrm{ft} \text {, hard layering. At } 95 \mathrm{ft} \\
\text { same as above. At } 100 \mathrm{ft} \text { same as above. At } 105 \mathrm{ft} \text { same } \\
\text { as above with rig chatter, hard layering. At } 110 \mathrm{ft} \text { same } \\
\text { as above with rig chatter, hard layering. At } 115 \mathrm{ft} \text { same } \\
\text { as above. }\end{array}$ \\
\hline
\end{tabular}

$\begin{array}{llll}\text { Aquaeter MW-327 } & 36.58 & 48.77 \quad \text { sand and gravel }\end{array}$

Aquaeter MW-327

Aquaeter MW-327

49.07

$53.34 \quad$ sand, clay and gravel

Aquaeter MW-327

53.34

56.39

sand, clay and gravel

Aquaeter MW-327

56.39
60.96
Same as above. $125 \mathrm{ft}$ brown, fine to medium-grained silty sand with 10-20\% fine gravel, dry. At $130 \mathrm{ft}$ same as above, easy drilling. At $135 \mathrm{ft}$ same as above with rig chatter at $135 \mathrm{ft}$ with and minor fine to coarse gravel return. At $140 \mathrm{ft}$ same as above. At $145 \mathrm{ft}$ same as above, easy drilling. At $150 \mathrm{ft}$ same as above. At $155 \mathrm{ft}$ same as above.

Same as above.

Brown, well graded, medium to fine-grained silty sand with $25 \%$ fine-gained gravel, subrounded, dry. At $165 \mathrm{ft}$ same as above. At $170 \mathrm{ft}$ same as above.

Brown, fine subangular to subrounded gravel with slightly silty coarse sand. At $180 \mathrm{ft}$ same as above, rig chatter.

Brown, well graded, medium to coarse-grained silty sand with fine subrounded gravel, rig chatter, dry. At $190 \mathrm{ft}$ brown, well graded, fine to medium-grained silty sand (50-60\%) with subrounded fine gravel, dry. At $195 \mathrm{ft}$ same as above. 
Appendix 1. Compilation of borehole and aquifer data.-Continued

[cm, centimeter; m, meter; in, inch; ft, feet; \%, percent; ppm, parts per million; $\approx$, approximately equal to; $>$, greater than]

\begin{tabular}{|c|c|c|c|c|}
\hline Bore & $\begin{array}{l}\text { Top } \\
\text { (m) }\end{array}$ & $\begin{array}{l}\text { Bottom } \\
(\mathrm{m})\end{array}$ & Simplified lithology & Driller's description \\
\hline Aquaeter MW-327 & 60.96 & 62.48 & sand, clay and gravel & $\begin{array}{l}\text { Brown, well graded, fine subrounded gravel with medium } \\
\text { to coarse-grained silty sand. }\end{array}$ \\
\hline Aquaeter MW-327 & 62.48 & 73.15 & sand, clay and gravel & $\begin{array}{l}\text { Brown, well graded, medium-grained silty sand with } \\
\text { fine subrounded gravel dry. At } 210 \mathrm{ft} \text { same as above. } \\
\text { At } 215 \mathrm{ft} \text { same as above. At } 220 \mathrm{ft} \text { same as above. At } \\
225 \mathrm{ft} \text { brown, fine to coarse-grained silty sand with fine } \\
\text { gravel, dry. At } 230 \mathrm{ft} \text { same as above. At } 235 \mathrm{ft} \text { medium } \\
\text { to coarse-grained silty sand }(80 \%) \text { with fine, subrounded } \\
\text { gravel, dry. }\end{array}$ \\
\hline
\end{tabular}

Aquaeter MW-327

73.15

79.25

sand, clay and gravel

Aquaeter MW-327

79.25

85.34

sand, clay and gravel

Aquaeter MW-327

Aquaeter MW-327

86.87

91.44

sand, clay and gravel

Aquaeter MW-327

91.44

97.54

sand, clay and gravel

Aquaeter MW-327

97.54

100.58

sand, clay and gravel

Aquaeter MW-327

100.58 sand, clay and gravel
Same as above. At $245 \mathrm{ft}$ same as above, easy drilling. At $250 \mathrm{ft}$ same as above, easy drilling. At $255 \mathrm{ft}$ same as above, easy drilling, lost circulation at $250 \mathrm{ft}, 255 \mathrm{ft}$ no return from borehole, 40-50 ft interval open.

Brown, well graded, fine subangular gravel with medium to fine-grained sand, dry. At $265 \mathrm{ft}$ same as above, easy drilling, rig air in being lost to the formation. At $270 \mathrm{ft}$ well graded, fine to coarse gravel with silty sand, subangular to subrounded, dry. At $275 \mathrm{ft}$ same as above.

Same as above.

Brown, fine to medium-grained silty sand (50\%) with fine subangular gravel, dry. At $290 \mathrm{ft}$ brown-gray, poorly graded, medium to coarse-grained sand with $10-15 \%$ fine subangular to subrounded gravel, dry. At $295 \mathrm{ft}$ same as above with thin layer of fine silty sand with minor fine gravel driller reports cemented layer.

Brown, well graded, coarse-grained silty sand with fine subangular gravel, rig chatter and harder drilling cemented layer, dry. At $305 \mathrm{ft}$ same as above. At $310 \mathrm{ft}$ brown, fine-grained silty sand (75\%) with fine gravel, rig chatter, dry. At $315 \mathrm{ft}$ same as above, cemented.

Same as above, hard drilling. At $325 \mathrm{ft}$ same as above.

Brown, well graded, fine to coarse subrounded gravel with silty sand, dry. At $335 \mathrm{ft}$ same as above. Static groundwater $335 \mathrm{ft}$. At 340 same as above, rig chatter. At $345 \mathrm{ft}$ same as above, rig chatter. At $350 \mathrm{ft}$ same as above. At $355 \mathrm{ft}$ same as above. Groundwater detected in bore hole at $\geq 356 \mathrm{ft}$ and rising, slight increase in sand and silt moist sample at $360 \mathrm{ft}$. 
Appendix 1. Compilation of borehole and aquifer data.-Continued

[cm, centimeter; $\mathrm{m}$, meter; in, inch; $\mathrm{ft}$, feet; $\%$, percent; ppm, parts per million; $\approx$, approximately equal to; >, greater than]

\begin{tabular}{ccccc}
\hline Bore & $\begin{array}{c}\text { Top } \\
(\mathbf{m})\end{array}$ & $\begin{array}{c}\text { Bottom } \\
(\mathbf{m})\end{array}$ & Simplified lithology & Driller's description \\
\hline G\&M Inc 001 & 0.00 & 12.19 & sand, clay and gravel & $\begin{array}{c}\text { Silty gravel, silty gravel, brown }(7.5 \mathrm{YR} 5 / 2), 20 \% \text { low plas- } \\
\text { ticity fines, 20\% fine to coarse sand, 60\% fine to coarse } \\
\text { gravel, trace cobbles Iron oxide staining on grains. At }\end{array}$ \\
& & & $5 \mathrm{ft}$, increase in moisture.
\end{tabular}

$\begin{array}{ccc}12.19 & 15.54 \quad \begin{array}{c}\text { sand, clay and trace } \\ \text { gravel }\end{array}\end{array}$

G\&M Inc 001

15.54

18.29

sand, clay and gravel

G\&M Inc 001

18.29

19.8

sand and trace gravel

G\&M Inc 001

19.81

21.34

sand and gravel

G\&M Inc 001

21.34

24.38

sand, clay and gravel

G\&M Inc 001

24.38

27.43

sand, clay and trace

gravel

G\&M Inc 001

27.43

28.96

sand and trace gravel

G\&M Inc 001

28.96

32.92

sand, clay and trace gravel

G\&M Inc 001
39.62
Silty sand, silty sands, brown (7.5YR5/4), 30\% low plasticity fines, $60 \%$ very fine to medium sand, round to subrounded, $10 \%$ fine gravel, iron oxide staining on grains, very dense.

Silty gravel, silty gravel, brown (7.5YR5/4), 25\% low plasticity fines, $20 \%$ fine to coarse sand, $55 \%$ fine to coarse gravel, iron oxide staining on grains.

Gravelly sand, gravelly sand, brown (7.5YR5/4), 5-10\% low plasticity dry fines, $80-85 \%$ fine to medium sand, $5-10 \%$ fine to coarse gravel, very dense,.

Sandy gravel, sandy gravel, brown (7.YR5/4), 10\% low plasticity fines, $30 \%$ fine to coarse sand, $60 \%$ fine to coarse gravel, round to subrounded, moderate iron oxide staining on grains.

Silty sand, silty sands, brown (7.5YR5/4), 25\% low plasticity fines, $20 \%$ fines to coarse sand, $55 \%$ fine to coarse gravel, iron oxide staining on grains. At $75 \mathrm{ft} 1-$ foot interbeds of gravel.

Silty sand, silty sands, brown (10YR5/3), 20\% low plasticity fines, $70 \%$ very fine to medium sand, subrounded, $10 \%$ fine gravel, trace iron oxide staining on grains.

Gravelly sand, gravelly sand, brown (10YR5/3), 5-10\% low plasticity fines, $50 \%$ fine to coarse sand, $40-45 \%$ fine to coarse gravel, moderate iron oxide staining on grains.

Silty, sand, silty sands, brown (7.5YR5/4), 20\% low plasticity fines, $75 \%$ very fine to medium sand, $5 \%$ fine gravel, abundantly iron oxide staining on grains. At $100 \mathrm{ft}$, increase in fine gravel to $10 \%$.

Silty gravel, silty gravel, brown (7.5YR5/4), 20\% low plasticity fines, $10 \%$ sand, $70 \%$ fine to coarse gravel, abundant iron oxide staining on grains. 
Appendix 1. Compilation of borehole and aquifer data.-Continued

[cm, centimeter; m, meter; in, inch; ft, feet; \%, percent; ppm, parts per million; $\approx$, approximately equal to; $>$, greater than]

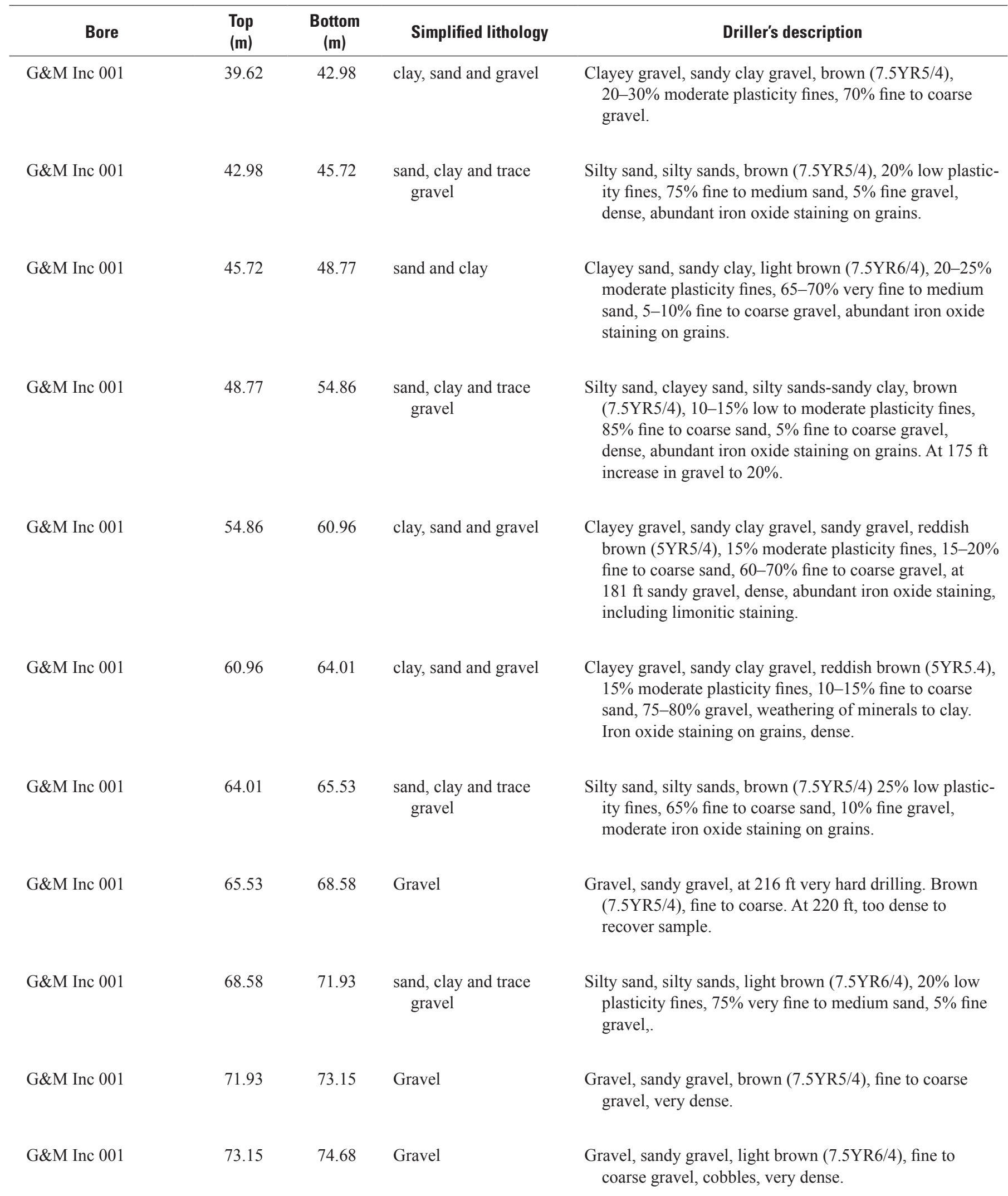


Appendix 1. Compilation of borehole and aquifer data.-Continued

[cm, centimeter; $\mathrm{m}$, meter; in, inch; $\mathrm{ft}$, feet; $\%$, percent; ppm, parts per million; $\approx$, approximately equal to; >, greater than]

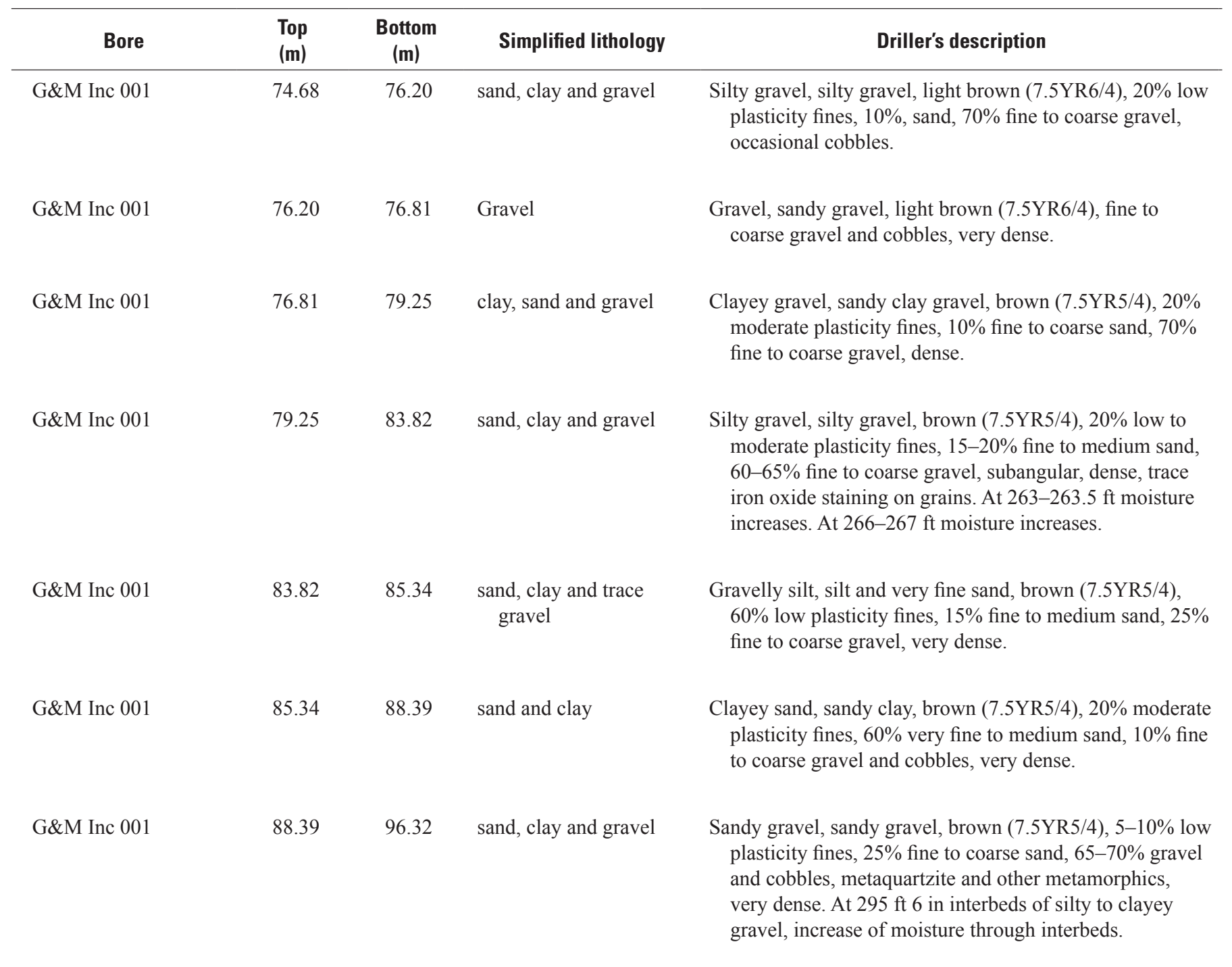

G\&M Inc 001

96.32

97.54

sand and trace gravel

G\&M Inc 001

97.54

99.36

Gravel

G\&M Inc 001

99.36

100.58

sand, clay and gravel

103.63 Gravel

G\&M Inc 001

100.58

103.63
Gravelly sand, gravelly sand, light brown (7.5YR6/4), 15\% low plasticity fines, $70 \%$ fine to coarse sand, $15 \%$ fine to coarse gravel, very dense.

Gravel, sandy gravel, light brown (7.5YR6/4), gravel and cobbles, very dense, quartz, quartzite, other metamorphics. At $325 \mathrm{ft}$ fragments of cobbles or boulders.

Silty gravel and sand, silty gravel-silty sands, light brown (7.5YR6/4).

Gravel, sandy gravel light brown (7.5YR6/4), very dense.
Clayey sand, sandy clay, light brown (7.5YR6/4), 20\% moderate plasticity fines, $65 \%$ to medium sand, $15 \%$ to coarse gravel, subrounded to round, moderate iron oxide staining on grains, very dense. 
Appendix 1. Compilation of borehole and aquifer data.-Continued

[cm, centimeter; m, meter; in, inch; ft, feet; \%, percent; ppm, parts per million; $\approx$, approximately equal to; $>$, greater than]

\begin{tabular}{|c|c|c|c|c|}
\hline Bore & $\begin{array}{l}\text { Top } \\
(\mathrm{m})\end{array}$ & $\begin{array}{l}\text { Bottom } \\
\text { (m) }\end{array}$ & Simplified lithology & Driller's description \\
\hline G\&M Inc 001 & 110.03 & 111.71 & sand and trace gravel & $\begin{array}{l}\text { Gravelly sand, gravelly sand, brown (7.5YR5/4). Total } \\
\text { depth } 366.5 \mathrm{ft} \text {. Boring terminated in gravelly sand at } \\
366.25 \mathrm{ft} \text { and converted to a monitoring well. }\end{array}$ \\
\hline G\&M Inc 002 & 0.00 & 2.44 & sand and clay & $\begin{array}{l}\text { Silt and very fine sand, silt to very fine sand, pinkish gray } \\
\text { (7.5YR6/2), well sorted. }\end{array}$ \\
\hline G\&M Inc 002 & 6.10 & 7.62 & sand, clay and gravel & $\begin{array}{l}\text { Gravelly sand, silty sands silty gravel, silty very fine to } \\
\text { medium sand }(60 \%) \text { and } 1 / 4-1 / 2 \text { in gravel }(40 \%) \text { light } \\
\text { brown }(7.5 \mathrm{YR} 6 / 4) \text {, poorly-sorted, angular stringers of } \\
\text { very fine sand interbedded. }\end{array}$ \\
\hline G\&M Inc 002 & 7.62 & 9.14 & sand, clay and gravel & $\begin{array}{l}\text { Silty sand, silty sands, light brown (7.5YR6/4), 20\% fines, } \\
70 \% \text { sand, 10\% gravel, (low plasticity fines in gravel at } \\
27 \mathrm{ft} \text { coarsening downward sequences). }\end{array}$ \\
\hline G\&M Inc 002 & 12.19 & 13.72 & sand and trace gravel & $\begin{array}{l}\text { Gravelly sand, gravelly sand, brown ( } 7.5 \text { YR } 5 / 4) 10-15 \% \\
\text { low plasticity fines, } 60 \% \text { sand, } 25-30 \% \text { coarse gravel, } \\
\text { subangular to subrounded, some angular, fine to coarse } \\
\text { sand, fine gravel. Gravel consists of SS, sHS, } 1 \mathrm{~S} \text {, mafics. }\end{array}$ \\
\hline G\&M Inc 002 & 13.72 & 16.76 & sand, clay and gravel & $\begin{array}{l}\text { Silty sand, silty sands, brown }(7.5 \mathrm{YR} 5 / 4), 20 \% \text { low plastic- } \\
\text { ity fines, } 75 \% \text { fine to coarse sand, } 5 \% \text { fine gravel, grains } \\
\text { subrounded to angular. }\end{array}$ \\
\hline G\&M Inc 002 & 16.76 & 21.34 & sand and trace gravel & $\begin{array}{l}\text { Gravelly sand, gravelly sand, brown }(7.5 \mathrm{YR} 5 / 4), 5-10 \% \\
\text { low plasticity fines, fine to coarse sand } 75 \%, 15 \% \text { fine to } \\
\text { coarse gravel ( } \leq 2 \text { in), subrounded. Dense to very dense. }\end{array}$ \\
\hline
\end{tabular}


Appendix 1. Compilation of borehole and aquifer data.-Continued

[cm, centimeter; $\mathrm{m}$, meter; in, inch; $\mathrm{ft}$, feet; \%, percent; ppm, parts per million; $\approx$, approximately equal to; >, greater than]

\begin{tabular}{ccccc}
\hline Bore & $\begin{array}{c}\text { Top } \\
(\mathbf{m})\end{array}$ & $\begin{array}{c}\text { Bottom } \\
(\mathbf{m})\end{array}$ & Simplified lithology & Driller's description \\
\hline G\&M Inc 002 & 21.34 & 24.38 & sand and gravel & $\begin{array}{c}\text { Sand gravel, sandy gravel, brown }(7.5 \mathrm{YR} 5 / 4), 5-10 \% \text { low } \\
\text { plasticity fines, 25-30\% sand, 65\% } \\
\text { rounded to subangular gravel, some iron oxide staining } \\
\text { on grains (2.4YR3/4). At } 75 \mathrm{ft} \text {, color dark reddish brown } \\
\text { to dark brown (7.5YR4/4) with combined grains. }\end{array}$ \\
& & &
\end{tabular}

G\&M Inc 002

G\&M Inc 002

G\&M Inc 002

27.43

35.05

clay and sand

G\&M Inc 002

35.05

36.58

clay, sand and gravel

G\&M Inc 002

36.58

38.10

sand, clay and gravel

G\&M Inc 002

38.10

39.62

sand, clay and gravel

G\&M Inc 002

39.62

41.15

sand, clay and gravel

G\&M Inc 002

41.15

42.67

sand, clay and gravel

G\&M Inc 002

42.67

47.24

sand and trace gravel

$47.24 \quad 48.77 \quad$ sand and gravel
Silty sand, silty sands, brown (10YR5/3), 15-20\% low to moderate plasticity fines, $60-70 \%$ fine to coarse sand, $15-20 \%$ fine to coarse gravel, very dense.

Gravel, sandy gravel, brown (10YR $5 / 3$ ), 5\% fines, 5\% fine to coarse sand, $90 \%$ fine to coarse gravel.

Clayey, sand, sandy clay, reddish Yellow (5YR6/6), moderate plasticity fines, $55 \%$ fine to coarse sand, $20 \%$ fine to coarse gravel, Fe oxide staining throughout, partially cemented, very dense, grains round to subangular. At $110 \mathrm{ft}$ sandy clay, decrease in gravel to $10 \%$, fines increase to $35 \%$.

Clayey gravel, sandy clay gravel, reddish brown (5YR5/4), $20 \%$ fines, $10 \%$ sand, $70 \%$ fine to coarse, subrounded to subangular gravel.

Silty sand, silty sands, reddish yellow (7.5YR6/6), $15 \%$ low plasticity fines, $70 \%$ fine to coarse, round -subangular sand, $15 \%$ fine to coarse gravel, very dense, moderate Fe oxide staining on grains, moderately indurated.

Gravelly sand, with increase in gravel to $20 \%$.

Decrease in gravel to $15 \%$, reddish brown (5YR5/4).

Silty gravel, silty gravel, reddish brown (5YR5/4), 20\% low plasticity fines, $10-15 \%$ fine -coarse sand, $65-70 \%$ fine to coarse gravel, $\mathrm{Fe}$ oxide staining on grains, round to subangular.

Gravelly sand, gravelly sand, light reddish brown (5YR6/4) $5 \%$ low plasticity fines, $60 \%$ fine to coarse round to subangular sand, $35 \%$ fine to coarse gravel, Fe oxide staining on some grains, very dense. At $149 \mathrm{ft}$ sand to $70 \%$.

Sandy gravel, sandy gravel, light reddish brown (5YR6/4), $5-10 \%$ low plasticity fines, $40 \%$ fine to coarse sand, $50-55 \%$ fine to coarse gravel, Fe oxide staining on some grains. 
Appendix 1. Compilation of borehole and aquifer data.-Continued

[cm, centimeter; m, meter; in, inch; ft, feet; \%, percent; ppm, parts per million; $\approx$, approximately equal to; $>$, greater than]

\begin{tabular}{|c|c|c|c|c|}
\hline Bore & $\begin{array}{l}\text { Top } \\
\text { (m) }\end{array}$ & $\begin{array}{c}\text { Bottom } \\
(\mathrm{m})\end{array}$ & Simplified lithology & Driller's description \\
\hline G\&M Inc 002 & 53.34 & 54.86 & clay, sand and gravel & $\begin{array}{l}\text { Clayey gravel, sandy clay gravel, reddish brown (5YR4/4), } \\
10 \% \text { low plasticity fines, } 25 \% \text { fine to coarse sand, } 65 \% \\
\text { fine to coarse gravel. }\end{array}$ \\
\hline G\&M Inc 002 & 57.61 & 60.96 & clay, sand and gravel & Silty gravel-sandy gravel, sand to $20 \%$, fines $25 \%$. \\
\hline G\&M Inc 002 & 60.96 & 64.01 & sand and trace gravel & $\begin{array}{l}\text { Gravelly sand, gravelly sand, reddish brown (5YR5/4), 5\% } \\
\text { low plasticity fines, } 70 \% \text { fine to coarse sand, round to } \\
\text { subangular, fine to coarse gravel, very dense, Fe oxide } \\
\text { staining on grains. At } 208 \mathrm{ft} \text { very hard. }\end{array}$ \\
\hline G\&M Inc 002 & 64.01 & 66.60 & sand and trace gravel & $\begin{array}{l}\text { Gravelly sand, brown }(7.5 \mathrm{YR} 4 / 2), 5-10 \% \text { fine gravel, } \\
80 \%, \leq 20 \% \text { coarse gravel to cobbles, very dense, } \\
\text { Fe oxide staining on grains. }\end{array}$ \\
\hline G\&M Inc 002 & 69.34 & 71.63 & clay, sand and gravel & $\begin{array}{l}\text { Clayey gravel, sandy clay gravel, reddish yellow } \\
\text { ( } 7.5 \text { YR6/6), 25-30\% low-moderate plasticity fines, } 15 \% \\
\text { sand, at } 231 \mathrm{ft} 50-55 \% \text { fine to coarse gravel, Fe oxide } \\
\text { staining on grains. }\end{array}$ \\
\hline G\&M Inc 002 & 71.63 & 74.07 & sand and gravel & $\begin{array}{l}\text { Sandy gravel, sandy gravel, reddish brown ( } 5 \text { YR } 5 / 4) \text {, } \\
5 \% \text { low plasticity fines, } 15-20 \% \text { medium coarse sand, } \\
80-75 \% \text { fine to coarse gravel, Fe oxide staining on } \\
\text { grains. }\end{array}$ \\
\hline G\&M Inc 002 & 74.07 & 76.20 & $\begin{array}{l}\text { sand, clay and trace } \\
\text { gravel }\end{array}$ & $\begin{array}{l}\text { Silty sand, silty sands, reddish brown ( } 5 \text { YR } 5 / 3), 20 \% \text { low } \\
\text { plasticity fines, } 70 \% \text { fine-medium sand, } 10 \% \text { fine gravel, } \\
\text { grains subrounded. }\end{array}$ \\
\hline
\end{tabular}


Appendix 1. Compilation of borehole and aquifer data.-Continued

[cm, centimeter; $\mathrm{m}$, meter; in, inch; ft, feet; \%, percent; ppm, parts per million; $\approx$, approximately equal to; >, greater than]

\begin{tabular}{|c|c|c|c|c|}
\hline Bore & $\begin{array}{l}\text { Top } \\
\text { (m) }\end{array}$ & $\begin{array}{c}\text { Bottom } \\
\text { (m) }\end{array}$ & Simplified lithology & Driller's description \\
\hline G\&M Inc 002 & 76.20 & 81.38 & Gravel & $\begin{array}{l}\text { Gravel, sandy gravel-gravel, little or no fines, brown, } \\
\text { mixed gravel-quartz, metamorphics, granite, etc. Very } \\
\text { hard drilling. Fe oxide staining on some grain. Partially } \\
\text { cemented to be so hard. }\end{array}$ \\
\hline
\end{tabular}

G\&M Inc 002

81.38

84.43

clay and sand

G\&M Inc 002

84.43

88.39

sand, clay and gravel

G\&M Inc 002

G\&M Inc 002

92.96

sand and clay

G\&M Inc 002

92.96

100.28

sand and gravel

G\&M Inc 002

100.28

103.63

sand and trace gravel

G\&M Inc 002

103.63

106.68

sand and trace gravel

G\&M Inc 002

106.68

109.73

sand, clay and gravel

G\&M Inc 002
112.78

sand, clay and gravel
Sandy clay-sandy silt, silt and very fine sand/clay, pinkish gray (5YR7/2), 95\% fines, low-moderate plasticity, $5 \%$ fine sand, flecks of biotite and other dark minerals, weakly weathered, stiff to hard. Volcanic origin, few gravel, weathered white feldspars.

Sandy gravel, hard to dense, silty gravel, hard very dense. At $283 \mathrm{ft}$ silty gravel, light brown, very dense (7.5YR6/4), 30\% low plasticity fines, $20 \%$ fine to coarse sand, $50 \%$ fine to coarse gravel, very dense, traces of Fe oxide staining on grains.

Gravel, sandy gravel, very dense. At $295 \mathrm{ft}$ silty gravel, silty gravel.

Clayey sand, sandy clay, light brown (7.5YR6/4), 25\% moderately plasticity fines, stiff, $65 \%$ fine coarse sand, $10 \%$ fine to coarse gravel, trace Fe oxide staining.

Sandy gravel, sandy gravel, light brown (7.5YR6/4), 20\% moderate plasticity fines, $30 \%$ fine to medium sand, $50 \%$ fine to coarse gravel, medium dense. At $309 \mathrm{ft}$, very dense, cobbles and boulders. At $315 \mathrm{ft}$ very dense.

Gravelly sand, gravelly sand, light brown, 20\% fines, $60 \%$ fine to coarse sand, $20 \%$ fine to coarse gravel, Fe oxide staining on some grains, very dense.

Gravelly sand, gravelly sand, very pale brown (10YR7/4).

Silty gravel, silty gravel, light brown, $30 \%$ low plasticity fines, $20 \%$ fine to coarse sand, $50 \%$ fine to coarse gravel with cobbles, Fe oxide staining on grains, medium dense.

Clayey-sandy gravel, sandy clay gravel, light brown, $20-30 \%$ moderately plasticity fines, $20-30 \%$ fine to medium sand, $40-60 \%$ fine to coarse gravel with cobbles. At $365 \mathrm{ft}$ sandy clay gravel, reddish brown (7.5YR6/6), Fe oxide staining, 1 1/2 ft, gravel, hard. 
Appendix 1. Compilation of borehole and aquifer data.-Continued

[cm, centimeter; m, meter; in, inch; ft, feet; \%, percent; ppm, parts per million; $\approx$, approximately equal to; $>$, greater than]

\begin{tabular}{|c|c|c|c|c|}
\hline Bore & $\begin{array}{l}\text { Top } \\
\text { (m) }\end{array}$ & $\begin{array}{c}\text { Bottom } \\
\text { (m) }\end{array}$ & Simplified lithology & Driller's description \\
\hline G\&M Inc 002 & 112.78 & 114.30 & sand and trace gravel & $\begin{array}{l}\text { Gravelly sand, hard streak, gravelly sand, light reddish } \\
\text { brown (5YR6/4), } 15 \% \text { low plasticity fines, } 60 \% \text { very } \\
\text { fine to coarse sand, subrounded, } 25 \% \text { fine to coarse } \\
\text { gravel, abundant Fe oxide staining, medium dense to } \\
\text { dense. }\end{array}$ \\
\hline
\end{tabular}

G\&M Inc 600

G\&M Inc 600

G\&M Inc 600

G\&M Inc 600

G\&M Inc 600

G\&M Inc 600

G\&M Inc 600

G\&M Inc 600
4.57

10.36

sand and trace gravel

10.36

13.11

sand and trace gravel

13.11

15.5

sand and trace gravel

15.54

19.5

sand and trace gravel

$19.51 \quad 20.42 \quad$ sand and trace gravel

20.42

22.56

sand and gravel

22.5

22.56

sand and gravel

26.82

sand and gravel
Gravelly sand, gravelly sand, 20\% 1/4-1/2 in gravel in medium to coarse sand, subrounded, poorly sorted, light brown (7.5YR6/4).

Gravelly sand, gravelly sand, $40 \% 1 / 4$ in gravel, $5 \% 1$ in gravel, $55 \%$ medium to coarse sand, subrounded, poorly sorted.20\% 1/4-1/2 in gravel in medium to coarse sand, subrounded, poorly sorted, light brown (7.5YR6/4). At $40 \mathrm{ft}$ surface casing (12 1/4 in diameter) to 39.8 .

Gravelly sand, gravelly sand, $20 \% 1$ in gravel, $20 \% 1 / 4$ in gravel, $60 \%$ medium-coarse-grained sand, poorly sorted, subrounded. At $47 \mathrm{ft}$ change to down hole bit.

Gravelly sand, gravelly sand, 30\% 1/4 in gravel, 70\% fine to coarse sand, rounded, poorly sorted.

Gravelly sand, gravelly sand, 10\% 1/4 in gravel, fine to coarse sand $90 \%$.

Gravelly sand, 10\% 3/4 in gravel, 30\% 1/2-1/4 in gravel, subrounded, poorly sorted, fine to coarse sand.

Gravelly sand, 20\% 1/4 in gravel, increased fine sand (fine to coarse sand $80 \%$ ) (discharge hose came loose, filled with gravel).

Gravelly sand, 10\% 1/4 in gravel, $90 \%$ fine to coarse sand, subrounded, poorly sorted, light brown (7.5YR6/4). 
Appendix 1. Compilation of borehole and aquifer data.-Continued

[cm, centimeter; $\mathrm{m}$, meter; in, inch; $\mathrm{ft}$, feet; $\%$, percent; ppm, parts per million; $\approx$, approximately equal to; >, greater than]

\begin{tabular}{|c|c|c|c|c|}
\hline Bore & $\begin{array}{l}\text { Top } \\
(\mathrm{m})\end{array}$ & $\begin{array}{l}\text { Bottom } \\
\text { (m) }\end{array}$ & Simplified lithology & Driller's description \\
\hline G\&M Inc 600 & 26.82 & 29.87 & sand and gravel & $\begin{array}{l}\text { Gravelly sand, } 1 / 4 \text { in gravel, } 60 \% \text { fine to coarse sand, less } \\
\text { fine sand, subrounded, poorly sorted. At } 92 \mathrm{ft} 1 / 4 \mathrm{in} \\
\text { gravel and increased fines. }\end{array}$ \\
\hline G\&M Inc 600 & 28.04 & 29.87 & sand and gravel & . \\
\hline G\&M Inc 600 & 29.87 & 32.00 & sand, clay and gravel & $\begin{array}{l}\text { Gravelly sand-silty sands, } 20 \% 1 / 4 \text { in gravel, } 10-20 \% \text { silt, } \\
\quad 60-70 \% \text { fine to coarse sand, poorly sorted, subrounded. }\end{array}$ \\
\hline G\&M Inc 600 & 29.87 & 32.00 & sand, clay and gravel & $\begin{array}{l}\text { Gravelly sand/clay, } 10 \% 1 / 2 \text { in gravel, } 30 \% 1 / 4 \text { in gravel, } \\
60 \% \text { medium to coarse sand, subangular, trace of orange } \\
\text { sandy clay, brown }(7.5 \mathrm{YR} 5 / 2) \text {. }\end{array}$ \\
\hline G\&M Inc 600 & 33.53 & 36.58 & clay and sand & $\begin{array}{l}\text { Sandy gravel, } 50 \% \text { subangular gravel } 1 / 4 \mathrm{in}, 10 \% \text { orange } \\
\text { sandy clay, } 40 \% \text { medium to coarse sand. At } 113 \mathrm{ft} \text { lost, } \\
8 \mathrm{ft} \text { of hole overnight. No clay. }\end{array}$ \\
\hline G\&M Inc 600 & 36.58 & 37.80 & sand, clay and gravel & $\begin{array}{l}\text { Gravelly sand, } 40 \% \text { subrounded } 1 / 4 \text { in gravel, } 10 \% \text { silty } \\
\text { very fine sand, } 50 \% \text { fine to coarse sand, poorly sorted. }\end{array}$ \\
\hline G\&M Inc 600 & 44.20 & 45.42 & sand, clay and gravel & $\begin{array}{l}\text { Sandy clay gravel, } 30 \% 1 / 2 \text { in, } 30 \%, 1 / 4 \text { in gravel, coated } \\
\text { with sandy clay. }\end{array}$ \\
\hline G\&M Inc 600 & 45.42 & 46.63 & sand and clay & Silty sands, silty medium to coarse sand. \\
\hline G\&M Inc 600 & 46.63 & 48.77 & gravel & Gravelly sand, $20 \% 1 / 4$ in gravel. \\
\hline G\&M Inc 600 & 48.77 & 49.68 & sand and gravel & $\begin{array}{l}\text { Gravelly sand, } 40 \% 1 / 4 \text { in gravel, subangular, } 60 \% \text { fine to } \\
\text { coarse sand, poorly sorted. }\end{array}$ \\
\hline G\&M Inc 600 & 49.68 & 50.29 & sand, clay and gravel & $20 \%$ gravel, more silty. \\
\hline G\&M Inc 600 & 50.29 & 51.82 & sand and clay & Silty sands, fine to coarse silty sand. \\
\hline
\end{tabular}


Appendix 1. Compilation of borehole and aquifer data.-Continued

[cm, centimeter; m, meter; in, inch; ft, feet; \%, percent; ppm, parts per million; $\approx$, approximately equal to; $>$, greater than]

\begin{tabular}{|c|c|c|c|c|}
\hline Bore & $\begin{array}{l}\text { Top } \\
(\mathrm{m})\end{array}$ & $\begin{array}{l}\text { Bottom } \\
\text { (m) }\end{array}$ & Simplified lithology & Driller's description \\
\hline G\&M Inc 600 & 51.82 & 52.43 & sand and clay & Clay, $10 \%$ clay (soft). \\
\hline G\&M Inc 600 & 52.43 & 54.56 & sand, clay and gravel & Gravelly sand, 20\% 1/4 in gravel, subangular. \\
\hline G\&M Inc 600 & 57.00 & 59.44 & sand, clay and gravel & Gravelly sand, $40 \%$ gravel $1 / 4$ in, $10 \%$ clay. \\
\hline G\&M Inc 600 & 59.44 & 63.09 & sand, clay and gravel & $\begin{array}{l}\text { Gravelly sand-silty sands, } 40 \% 1 / 4 \text { in gravel, } 20 \% \text { silt and } \\
\text { clay. }\end{array}$ \\
\hline G\&M Inc 600 & 65.23 & 66.75 & sand, clay and gravel & $\begin{array}{l}\text { Gravelly sand/sandy clay, } 30 \% 1 / 4 \text { in gravel,5\% clay, } 75 \% \\
\text { medium to coarse sand. }\end{array}$ \\
\hline G\&M Inc 600 & 66.75 & 68.28 & sand and gravel & Gravelly sand, $10 \% 1 / 2$ in, $20 \% 1 / 4$ in, no clay. \\
\hline G\&M Inc 600 & 66.75 & 68.28 & sand and gravel & Gravelly sand, $10 \% 1 / 2$ in, $20 \% 1 / 4$ in, no clay. \\
\hline G\&M Inc 600 & 68.28 & 69.80 & sand and gravel & $\begin{array}{l}\text { Gravelly sand/Sandy gravel, } 30 \% 1 / 2 \text { in, } 20 \% 1 / 4 \text { in } \\
\text { gravel, } 50 \% \text { medium coarse sand. }\end{array}$ \\
\hline G\&M Inc 600 & 73.15 & 74.07 & sand and clay & Silty sands, very silty, very fine to coarse sand. \\
\hline G\&M Inc 600 & 74.07 & 75.29 & sand and clay & $\begin{array}{l}\text { Gravelly sand/silty sands, } 50 \% \text { coarse sand and } 1 / 4 \text { in } \\
\text { gravel } 50 \% \text { silt to fine sand. }\end{array}$ \\
\hline G\&M Inc 600 & 75.29 & 76.20 & sand and clay & Silty sands, $20 \%$ silt, $80 \%$ fine to coarse sand. \\
\hline G\&M Inc 600 & 76.20 & 77.42 & sand and clay & Gravelly sand, fine to coarse sand, rounded. \\
\hline G\&M Inc 600 & 77.42 & 78.33 & sand and clay & $\begin{array}{l}\text { Sandy gravel, } 70 \% 1 / 2 \text { in gravel, tough drilling, cobbles } \\
\text { (?). }\end{array}$ \\
\hline G\&M Inc 600 & 78.33 & 78.64 & sand and clay & Silty sands, silty fine sand. \\
\hline
\end{tabular}


Appendix 1. Compilation of borehole and aquifer data.-Continued

[cm, centimeter; $\mathrm{m}$, meter; in, inch; $\mathrm{ft}$, feet; $\%$, percent; ppm, parts per million; $\approx$, approximately equal to; >, greater than]

\begin{tabular}{|c|c|c|c|c|}
\hline Bore & $\begin{array}{l}\text { Top } \\
(\mathrm{m})\end{array}$ & $\begin{array}{l}\text { Bottom } \\
(\mathrm{m})\end{array}$ & Simplified lithology & Driller's description \\
\hline G\&M Inc 600 & 78.64 & 80.77 & sand and clay & Silty sands, silty fine to coarse sand, subrounded. \\
\hline G\&M Inc 600 & 80.77 & 81.99 & sand, clay and gravel & Gravelly sand, $40 \% 1 / 4$ in gravel, $60 \%$ silty fine sand. \\
\hline G\&M Inc 600 & 82.91 & 85.34 & sand and gravel & $\begin{array}{l}\text { Gravelly sand, } 20 \% 1 / 2 \text { in gravel, } 20 \% 1 / 4 \text { in } 60 \% \text { fine to } \\
\text { coarse sand. }\end{array}$ \\
\hline G\&M Inc 600 & 85.34 & 86.26 & sand and gravel & $\begin{array}{l}\text { Gravelly sand } 20 \% \text { subangular } 1 / 4 \text { in gravel, } 80 \% \text { medium } \\
\text { to coarse sand. }\end{array}$ \\
\hline G\&M Inc 600 & 87.48 & 89.61 & sand, clay and gravel & $\begin{array}{l}20 \% 1 / 4 \text { in gravel, } 80 \% \text { silty fine to coarse sand. No water } \\
\text { in pipe after } 1 \mathrm{hr} \text { at } 288 \mathrm{ft} \text {. At } 291 \mathrm{ft} 1 \mathrm{ft} \text { cobbles (?). }\end{array}$ \\
\hline G\&M Inc 600 & 89.61 & 91.14 & sand, clay and gravel & $\begin{array}{l}\text { Silty sands, } 20 \% \text { light brown clayey silt } 20 \% 1 / 4 \text { in gravel, } \\
40 \% \text { medium to coarse sand, no water measured due to } \\
\text { foam in pipe overnight. }\end{array}$ \\
\hline G\&M Inc 600 & 91.14 & 91.74 & sand, clay and gravel & $\begin{array}{l}\text { Silt and very fine sand, } 30 \%, 40 \% \text { light brown clayey silt, } \\
\text { gravel and sand, poorly sorted. }\end{array}$ \\
\hline G\&M Inc 600 & 92.81 & 94.79 & sand, clay and gravel & $\begin{array}{l}\text { Water level } 285.55 \mathrm{ft}, 1 / 18 / 89 \text {. Sandy gravel, rig chatter, } \\
\text { top of gravel coming into borehole. }\end{array}$ \\
\hline G\&M Inc 600 & 94.79 & 96.62 & $\begin{array}{l}\text { sand, clay and trace } \\
\text { gravel }\end{array}$ & $\begin{array}{l}\text { Water level } 290.73 \mathrm{ft}, 12 / 19 / 89 . \text { At } 311 \mathrm{ft} \text {, bounce on } \\
\text { gravel/cobbles (?). Silty sands } 30 \% \text {, clayey silt and } 65 \% \\
\text { fine to coarse sand, } 5 \% \text { gravel. }\end{array}$ \\
\hline G\&M Inc 600 & 96.62 & 98.45 & $\begin{array}{l}\text { sand, clay and trace } \\
\text { gravel }\end{array}$ & $\begin{array}{l}\text { Silt and very fine sand, } 50 \% \text { light brown, clayey silt, } 45 \% \\
\text { fine to coarse sand, } 5 \% \text { gravel. }\end{array}$ \\
\hline G\&M Inc 600 & 98.45 & 100.89 & $\begin{array}{l}\text { sand, clay and trace } \\
\text { gravel }\end{array}$ & $\begin{array}{l}\text { Silt and very fine sand, } 80 \% \text { light brown clayey silt, } 5 \% \\
\text { gravel } 1 / 4-1 / 2 \text { in. At } 325 \mathrm{ft} \text {, water level } 311.35 \mathrm{ft} \text {, } \\
\text { 12/19/89. }\end{array}$ \\
\hline G\&M Inc 600 & 100.89 & 104.24 & sand and clay & $\begin{array}{l}\text { Silt and very fine sand, } 60 \% \text { clayey silt, } 15 \% \text { gravel } 25 \% \\
\text { sand. At } 335 \mathrm{ft} \text { water level } 309.97 \mathrm{ft}, 12 / 19 / 89 \text {. }\end{array}$ \\
\hline
\end{tabular}


Appendix 1. Compilation of borehole and aquifer data.-Continued

[cm, centimeter; $\mathrm{m}$, meter; in, inch; ft, feet; \%, percent; ppm, parts per million; $\approx$, approximately equal to; >, greater than]

\begin{tabular}{ccccc}
\hline Bore & $\begin{array}{c}\text { Top } \\
(\mathbf{m})\end{array}$ & $\begin{array}{c}\text { Bottom } \\
(\mathbf{m})\end{array}$ & Simplified lithology & Driller's description \\
\hline G\&M Inc 600 & 104.24 & 106.38 & sand, clay and gravel & $\begin{array}{c}\text { Silt and very fine sand-silty sands, } 60 \% \text { silt to very fine } \\
\text { sand } 15 \% 1 / 4-1 / 2 \text { in gravel, } 2 \% \text { fine to coarse sand. At } \\
\end{array}$ \\
& & & $345 \mathrm{ft} 316.68 \mathrm{ft}, 12 / 19 / 89$.
\end{tabular}

G\&M Inc 600

G\&M Inc 600

G\&M Inc 600

G\&M Inc 600

G\&M Inc 600

G\&M Inc 600

G\&M Inc 600

G\&M Inc 600

G\&M Inc 600

G\&M Inc 600

G\&M Inc 600

G\&M Inc 600

133.50

134.11

sand and clay

G\&M Inc 600

112.47

112.47

114.30

118.57

sand and clay gravel

sand and clay

sand

sand sand and trace gravel

sand and trace gravel

sand, clay and trace

clay, sand and gravel

Water level $301.14 \mathrm{ft}, 1 / 30 / 90$. Sand, gravelly sand, pale brown (10YR6/3).

Sand, pale brown (10YR6/3) very fine to medium-grained, moderately well indurated, mostly friable, $5-10 \%$ soft salt and clay, $1-5 \%$ fine to very fine gravel.

Very fine sand, gravelly sand, brown (10YR4/3) as above. At $440 \mathrm{ft}$ water level $308.65 \mathrm{ft}, 1 / 31 / 90$. 
Appendix 1. Compilation of borehole and aquifer data.-Continued

[cm, centimeter; $\mathrm{m}$, meter; in, inch; $\mathrm{ft}$, feet; $\%$, percent; ppm, parts per million; $\approx$, approximately equal to; >, greater than]

\begin{tabular}{|c|c|c|c|c|}
\hline Bore & $\begin{array}{l}\text { Top } \\
\text { (m) }\end{array}$ & $\begin{array}{c}\text { Bottom } \\
\text { (m) }\end{array}$ & Simplified lithology & Driller's description \\
\hline G\&M Inc 600 & 136.25 & 139.90 & sand and clay & $\begin{array}{l}\text { Clayey sand, sandy clay, increase in clay content to } \\
5-25 \% \text {, otherwise as above. Made less water than sand } \\
\text { unit above. }\end{array}$ \\
\hline G\&M Inc 600 & 139.90 & 142.65 & Gravel & $\begin{array}{l}\text { Gravel, sandy gravel, very fine to medium pebbles }(90 \%) \text {, } \\
\text { coarse/very coarse pebbles }(10 \%), \leq 11 / 2 \text { in diameter, } \\
\text { rig chatter, lithic fragments, volcanics quartz, poorly } \\
\text { sorted, angular to sub rounded, }>50 \% \text { fine pebble size } \\
\text { but ranges very fine to very coarse. At } 460 \mathrm{ft} \text { water level } \\
303.2 \mathrm{ft}, 2 / 1 / 90 \text {. }\end{array}$ \\
\hline
\end{tabular}

G\&M Inc 600

G\&M Inc 600

G\&M Inc 600

G\&M Inc 600

G\&M Inc 600

152.10

153.01

sand, clay and gravel

G\&M Inc 601

G\&M Inc 601

G\&M Inc 601

$142.65 \quad 143.26 \quad$ Gravel

$143.26 \quad 145.08 \quad$ Gravel

$145.08 \quad 146.30 \quad$ sand, clay and gravel

$146.30 \quad 152.10 \quad$ clay, sand and gravel
Silt, silt and very fine sand. Fine to medium pebble gravel $(50 \%)$, clay cement. Brown (7.5YR4/3), silt (75\%), fine clay $(10 \%)$, fine sand $(15 \%)$ tight clay, poor recovery due to lack of water down hole.

Gravelly silt, clay, as above, increase in gravel (fine to coarse), content to $20 \%$, gravel is coarsening with depth. Need heavy foam to lift gravel. At $502 \mathrm{ft}$ water level $415.8 \mathrm{ft}, 2 / 2 / 90$, total depth $5.02 \mathrm{ft}$.

No data.

Silty sand, silty sands, pale brown (10YR6/3) 80\% well rounded, well graded fine-grained sand and $20 \%$ fines moderately weathered.

Gravelly sand, gravelly sand, brown (10YR5/3) 50\% fine to coarse sand, $40 \%$ fine to coarse gravel, $10 \%$ fines. Partially cemented sands, fragments well-rounded to subangular quartzite, metamorphic and volcanic rocks. Weak to moderately weathered, at 15 in gravel reduced to $<10 \%$, mixed fine to coarse subrounded sands, $10 \%$ fines. 
Appendix 1. Compilation of borehole and aquifer data.-Continued

[cm, centimeter; m, meter; in, inch; ft, feet; \%, percent; ppm, parts per million; $\approx$, approximately equal to; $>$, greater than]

\begin{tabular}{|c|c|c|c|c|}
\hline Bore & $\begin{array}{l}\text { Top } \\
(\mathrm{m})\end{array}$ & $\begin{array}{l}\text { Bottom } \\
(\mathrm{m})\end{array}$ & Simplified lithology & Driller's description \\
\hline G\&M Inc 601 & 7.62 & 9.14 & sand & $\begin{array}{l}\text { Sand, well graded sand, dark brown ( } 7.5 \text { YR } 4 / 4) 90 \% \text { well } \\
\text { graded, well sorted fine sand, } 80 \% \text { quartz and quartz- } \\
\text { ite (well rounded) and } 20 \% \text { other met rocks weakly } \\
\text { weathered. }\end{array}$ \\
\hline G\&M Inc 601 & 10.67 & 13.72 & sand and clay & $\begin{array}{l}\text { Silty sand, silty sands, brown ( } 7.5 \text { YR4/4) } 70 \% \text { fine to } \\
\text { medium-grained well rounded sand, 30\% fines (silty). }\end{array}$ \\
\hline G\&M Inc 601 & 18.59 & 19.81 & sand and trace gravel & $\begin{array}{l}\text { Gravelly sand, gravelly sand, dark grayish brown } \\
\text { (10YR4/2) } 60 \% \text { medium to coarse-grained sand and } \\
40 \% \text { fine to coarse gravel partially cemented, moderately } \\
\text { weathered. Mostly volcanic rocks. }\end{array}$ \\
\hline G\&M Inc 601 & 19.81 & 22.86 & sand, clay and gravel & $\begin{array}{l}\text { At } 65 \mathrm{ft}, 90 \% \text { medium to coarse-grained sand, } 10 \% \text { fine } \\
\text { to coarse gravel fragment, } 75 \% \text { volcanic rocks, } 10 \% \\
\text { quartzite, } 10 \% \text { other metamorphic rocks. At } 70 \mathrm{ft}, 80 \% \\
\text { fine to coarse-grained sand, } 30 \% \text { fine to medium-grained } \\
\text { sand } 10 \% \text { fines (silty), partially cemented. Moderate } \\
\text { weathering. }\end{array}$ \\
\hline
\end{tabular}

G\&M Inc 601

22.86

G\&M Inc 601

G\&M Inc 601
24.38

sand and trace gravel

$24.38 \quad 27.43 \quad$ sand and clay

$27.43 \quad 30.48$

sand, clay and gravel
Sand, well graded sand, pale brown (10YR6/3) 90\% fine to medium sand, $5 \%$ fine gravel, $5 \%$ fines. Probably started at $73 \mathrm{ft}$.

Well graded sands. At $80-90 \%$ fine to coarse-grained sand, $10 \%$ fines (silts).

Gravelly sand, gravelly sand/gravel, little or no fines, brown $(10 \mathrm{YR} / 3) 60 \%$ fine to coarse-grained, poorly sorted sands, $35 \%$ fine to medium gravel, $5 \%$ fines (clayey silts), subrounded to angular, partially cemented, weakly weathered. At $95 \mathrm{ft}, 70 \%$ fine to coarse sand, $20 \%$ fine gravel, 10\% fines (silty clay), rounded to subangular, partially cemented.

Sand, well graded sand, pale brown (10YR6/3) 90\% fine to medium-grained sand, 5\% fine gravel, 5\% fines (clayey silts), weakly weathered, partially cemented. At $105 \mathrm{ft}$ fine to coarse sand, rig chatter on cobbles at 101-102 ft. 
Appendix 1. Compilation of borehole and aquifer data.-Continued

[cm, centimeter; $\mathrm{m}$, meter; in, inch; $\mathrm{ft}$, feet; $\%$, percent; ppm, parts per million; $\approx$, approximately equal to; >, greater than]

\begin{tabular}{|c|c|c|c|c|}
\hline Bore & $\begin{array}{l}\text { Top } \\
(\mathrm{m})\end{array}$ & $\begin{array}{l}\text { Bottom } \\
\text { (m) }\end{array}$ & Simplified lithology & Driller's description \\
\hline G\&M Inc 601 & 33.53 & 35.05 & sand and gravel & $\begin{array}{l}\text { At } 110 \mathrm{ft} \text {, coarse sand fragments } 50 \% \text { volcanic rocks, } 40 \% \\
\text { metamorphic rocks } 10 \% \text { quartz and quartzite. }\end{array}$ \\
\hline G\&M Inc 601 & 35.05 & 36.58 & sand and clay & $\begin{array}{l}\text { Silt sand, silty sands, brown (10YR5/3) 90\% fine to coarse- } \\
\text { grained sand, } 20 \% \text { fines (silty), moderately weathered. }\end{array}$ \\
\hline G\&M Inc 601 & 36.58 & 39.62 & $\begin{array}{l}\text { sand, clay and trace } \\
\text { gravel }\end{array}$ & $\begin{array}{l}\text { Sand, gravelly sand, pale brown (10YR6/3) 90\% fine to } \\
\text { coarse-grained sand, } 5 \% \text { fine gravel 5\% fines (clayey } \\
\text { silts), weakly weathered. Fragments } 70 \% \text { volcanic, } 20 \% \\
\text { metamorphic rocks, }(10 \% \text { ) quartz. }\end{array}$ \\
\hline G\&M Inc 601 & 42.67 & 44.20 & sand and clay & $\begin{array}{l}\text { Rig chatter at } 140 \mathrm{ft} \text { At } 140 \mathrm{ft}, 95 \% \text { medium to coarse- } \\
\text { grained sand, } 5 \% \text { silty fines (Fragments, } 60 \% \text { volcanic } \\
\text { rocks, } 40 \% \text { metamorphic rocks). }\end{array}$ \\
\hline G\&M Inc 601 & 44.20 & 45.72 & sand & $\begin{array}{l}\text { Well graded sand, well graded sand, Yellowish brown } \\
\text { (10YR5/4) 90\% fine gravel, well sorted, well rounded } \\
\text { sand, 10\% fines and medium-grained sand. }\end{array}$ \\
\hline G\&M Inc 601 & 45.72 & 47.24 & sand and trace gravel & $\begin{array}{l}\text { Gravelly sand, gravelly sand, brown (10YR } 5 / 3) 50 \% \text { fine } \\
\text { to coarse-grained sand, } 40 \% \text { fine to medium gravel, } 10 \% \\
\text { fine. }\end{array}$ \\
\hline G\&M Inc 601 & 50.29 & 51.82 & sand, clay and gravel & $\begin{array}{l}\text { At } 165 \mathrm{ft} \text {, clay reduced to } 10 \% \text { angular fragments of gravel } \\
(5-10 \%) \text { rest is fine to coarse-grained sand. }\end{array}$ \\
\hline G\&M Inc 601 & 51.82 & 53.34 & sand, clay and gravel & $\begin{array}{l}\text { At } 170 \mathrm{ft} \text {, clay at } 10 \% \text {, subrounded to angular gravel of } \\
\text { chert, volcanic angular gravel of chert, volcanic rocks } \\
\text { and quartz, at } 40 \%, 50 \% \text { fine to medium sand. }\end{array}$ \\
\hline G\&M Inc 601 & 53.34 & 54.86 & sand and gravel & $\begin{array}{l}175 \mathrm{ft} \text {, angular, moderately to well weathered fragment of } \\
\text { gravel of cherty, silicified volcanic rocks. }\end{array}$ \\
\hline G\&M Inc 601 & 54.86 & 56.39 & $\begin{array}{l}\text { sand, clay and trace } \\
\text { gravel }\end{array}$ & $\begin{array}{l}\text { Sand, gravelly sand, reddish brown (5YR5/4) } 85 \% \text { fine to } \\
\text { medium-grained sand, } 10 \% \text { fine to medium gravel } 5 \% \\
\text { silty fines. Rounded to subrounded, weakly weathered. }\end{array}$ \\
\hline
\end{tabular}


Appendix 1. Compilation of borehole and aquifer data.-Continued

[cm, centimeter; m, meter; in, inch; ft, feet; \%, percent; ppm, parts per million; $\approx$, approximately equal to; $>$, greater than]

\begin{tabular}{|c|c|c|c|c|}
\hline Bore & $\begin{array}{l}\text { Top } \\
\text { (m) }\end{array}$ & $\begin{array}{l}\text { Bottom } \\
\text { (m) }\end{array}$ & Simplified lithology & Driller's description \\
\hline G\&M Inc 601 & 56.39 & 59.44 & $\begin{array}{l}\text { sand, clay and trace } \\
\text { gravel }\end{array}$ & $\begin{array}{l}\text { Gravelly sand, brown (7.5YR5/4) } 85 \% \text { fine to coarse- } \\
\text { grained sand, } 10 \% \text { clayey silts, } 5 \% \text { fine gravel well } \\
\text { rounded to subangular. Fragments } 60 \% \text { volcanic, } 20 \% \\
\text { metamorphic rocks, and } 20 \% \text { quartz, poorly sorted. Rod } \\
\text { hop } 190 \mathrm{ft}, 194 \mathrm{ft} \text {. }\end{array}$ \\
\hline G\&M Inc 601 & 64.01 & 67.06 & sand and clay & $\begin{array}{l}\text { Sand, gravelly sand, brown (10YR5/3) } 95 \% \text { fine to } \\
\text { coarse-grained sand, } 5 \% \text { fines (silty), weakly cemented, } \\
\text { subrounded to subangular, weakly weathered. Fragments } \\
90 \% \text { volcanic rocks, } 10 \% \text { quartz and quartzite. }\end{array}$ \\
\hline G\&M Inc 601 & 67.06 & 68.58 & clay and sand & At $220 \mathrm{ft}, 5 \%$ clayey silty fines nearly a well-graded sand. \\
\hline G\&M Inc 601 & 68.58 & 70.10 & sand and clay & $\begin{array}{l}\text { Sand, well graded sand, brown }(7.5 \mathrm{YR} 5 / 4) \approx 95 \% \text { fine to } \\
\text { medium-grained, well-graded sand, }<5 \% \text { fines (silty), } \\
\text { rounded to subrounded, moderately weathered. }\end{array}$ \\
\hline G\&M Inc 601 & 70.10 & 70.10 & sand, clay and gravel & $\begin{array}{l}\text { Sand, gravelly sand, light brown }(7.5 \mathrm{YR} 6 / 4) 80 \% \text { fine to } \\
\text { coarse-grained sand, } 15 \% \text { fine gravel, } 5 \% \text { silty fines, } \\
\text { partially cemented, moderately weathered. Fragments } \\
90 \% \text { volcanic rocks, } 10 \% \text { quartz. }\end{array}$ \\
\hline G\&M Inc 601 & 76.20 & 77.72 & sand, clay and gravel & $\begin{array}{l}\text { At } 250 \mathrm{ft} \text {, gravel reduced to }<5 \% \text {, sand mostly fine to } \\
\text { medium-grained with }<5 \% \text { fines (silty). }\end{array}$ \\
\hline G\&M Inc 601 & 77.72 & 79.25 & sand, clay and gravel & $\begin{array}{l}\text { At } 255 \mathrm{ft}, 80 \% \text { fine to coarse-grained sand, } 15 \% \text { fine gravel } \\
5 \% \text { fine (silty) moderately weathered. }\end{array}$ \\
\hline G\&M Inc 601 & 79.25 & 80.77 & Gravel & At $260 \mathrm{ft}$, fine gravel increased to $20 \%$. \\
\hline G\&M Inc 601 & 80.77 & 82.30 & sand and gravel & $\begin{array}{l}\text { At } 265 \mathrm{ft}, 90 \% \text { medium to coarse-grained sand and 10\% } \\
\text { fine gravel. }\end{array}$ \\
\hline G\&M Inc 601 & 82.30 & 83.82 & sand and gravel & $\begin{array}{l}\text { At } 270 \mathrm{ft}, 90 \% \text { fine to coarse-grained sand and } 10 \% \text { fine } \\
\text { gravel, subrounded to subangular. }\end{array}$ \\
\hline
\end{tabular}


Appendix 1. Compilation of borehole and aquifer data.-Continued

[cm, centimeter; $\mathrm{m}$, meter; in, inch; ft, feet; \%, percent; ppm, parts per million; $\approx$, approximately equal to; >, greater than]

\begin{tabular}{|c|c|c|c|c|}
\hline Bore & $\begin{array}{l}\text { Top } \\
(\mathrm{m})\end{array}$ & $\begin{array}{c}\text { Bottom } \\
(\mathrm{m})\end{array}$ & Simplified lithology & Driller's description \\
\hline G\&M Inc 601 & 83.82 & 85.34 & sand and gravel & $\begin{array}{l}\text { At } 275 \mathrm{ft}, 80 \% \text { fine to coarse sand and } 20 \% \text { fine to medium } \\
\text { gravel. Fragments } 80 \% \text { volcanic rocks, } 10 \% \text { metamor- } \\
\text { phic rocks, } 10 \% \text { quartz. }\end{array}$ \\
\hline G\&M Inc 601 & 85.34 & 88.39 & $\begin{array}{l}\text { sand, clay and trace } \\
\text { gravel }\end{array}$ & $\begin{array}{l}\text { At } 280 \mathrm{ft}, 85 \% \text { medium to coarse-grained sand, } 10 \% \text { fine } \\
\text { gravel, }<5 \% \text { fines (silt), subrounded to angular. }\end{array}$ \\
\hline G\&M Inc 601 & 88.39 & 89.92 & sand & $\begin{array}{l}\text { Sand, well graded sand, dark yellowish-brown }(10 \%, 4 / 4) \\
90 \% \text { fine to medium well-graded sand, } 10 \% \text { fine and } \\
\text { coarse fraction moderately weathered, well rounded to } \\
\text { subangular. }\end{array}$ \\
\hline G\&M Inc 601 & 91.44 & 94.49 & $\begin{array}{l}\text { sand, clay and trace } \\
\text { gravel }\end{array}$ & $\begin{array}{l}\text { At } 300 \mathrm{ft} \text {, addition of } 5 \% \text { fines (silty). Gravelly sand at } \\
306-307 \mathrm{ft} \text {, slow drilling, low penetration rate. }\end{array}$ \\
\hline G\&M Inc 601 & 94.49 & 96.01 & sand and trace gravel & $\begin{array}{l}\text { Gravelly sand/sandy gravel. At } 310 \mathrm{ft}, 90 \% \text { fine to } \\
\text { medium-grained sand (minor coarse fraction), includes } \\
\text { angular, milky quartz fragment from probable cobbles or } \\
\text { coarse gravel, rig chatter at } 314-316 \mathrm{ft} \text {. }\end{array}$ \\
\hline G\&M Inc 601 & 99.06 & 102.11 & $\begin{array}{l}\text { sand, clay and trace } \\
\text { gravel }\end{array}$ & $\begin{array}{l}\text { At } 330 \mathrm{ft}, 10 \% \text { clayey silts in medium to coarse-grained } \\
\text { sand and } 10-20 \% \text { fine to medium gravel. Rig chatter at } \\
325 \mathrm{ft} \text {. }\end{array}$ \\
\hline G\&M Inc 601 & 102.11 & 103.63 & sand and clay & $\begin{array}{l}\text { Silty sand, silty sands, brownish yellow (10YR6/6) } \\
80-90 \% \text { fine to medium-grained, subrounded to angular } \\
\text { sand (minor coarse fraction) } 10 \% \text {, clayey silts, partially } \\
\text { cemented, weakly weathered. Angular fragments of } \\
\text { milky quartz broken from cobbles. }\end{array}$ \\
\hline G\&M Inc 601 & 103.63 & 106.68 & $\begin{array}{l}\text { sand, clay and trace } \\
\text { gravel }\end{array}$ & $\begin{array}{l}\text { Gravelly sand, gravelly sand, dark brown }(10 \text { YR } 5 / 3) \text {. At } \\
340 \mathrm{ft} \text {, angular chips of } 80 \% \text { quartz, quartzite and chert, } \\
20 \% \text { other metamorphic and volcanic rocks, } 90 \% \text { medi- } \\
\text { um to coarse sand, } 10 \% \text { clayey silty fines. At } 340-341 \mathrm{ft} \\
\text { cobbles, slow, hard drilling, cobbles, rig chatter at } 344 \mathrm{ft} \text {. }\end{array}$ \\
\hline
\end{tabular}


Appendix 1. Compilation of borehole and aquifer data.-Continued

[cm, centimeter; m, meter; in, inch; ft, feet; \%, percent; ppm, parts per million; $\approx$, approximately equal to; $>$, greater than]

\begin{tabular}{|c|c|c|c|c|}
\hline Bore & $\begin{array}{l}\text { Top } \\
\text { (m) }\end{array}$ & $\begin{array}{c}\text { Bottom } \\
\text { (m) }\end{array}$ & Simplified lithology & Driller's description \\
\hline G\&M Inc 601 & 106.68 & 108.20 & sand, clay and gravel & $\begin{array}{l}\text { At } 345 \mathrm{ft}, 50 \% \text { medium to coarse sand, } 40 \% \text { fine to coarse } \\
\text { gravel and cobbles, } 10 \% \text { fines (silty). Fragments } 80 \% \\
\text { quartz, quartzite, and cherts, } 20 \% \text { volcanic and meta- } \\
\text { morphic rocks. Heavy rig chatter at } 348 \mathrm{ft} \text { Slow hard } \\
\text { drilling. }\end{array}$ \\
\hline G\&M Inc 601 & 108.20 & 109.73 & sand and gravel & $\begin{array}{l}\text { Sandy gravel, sandy gravel/gravelly sand, light yellowish } \\
\text { brown (10YR6/4), } 70 \% \text { fine to coarse gravel } 30 \% \text { fine to } \\
\text { coarse sand, weakly weathered, subrounded to subangu- } \\
\text { lar. Fragments } 50 \% \text { quartz and quartzite, } 50 \% \text { volcanic } \\
\text { rocks. Light rig chatter. }\end{array}$ \\
\hline G\&M Inc 601 & 109.73 & 111.25 & sand and gravel & $\begin{array}{l}\text { Sandy gravel/gravelly sand At } 360 \mathrm{ft}, 50 \% \text { fine to coarse } \\
\text { gravel, } 50 \% \text { medium to coarse sand continued light rig } \\
\text { chatter. Starting to make water at } 364 \mathrm{ft} \text {. }\end{array}$ \\
\hline G\&M Inc 601 & 111.25 & 112.78 & sand and gravel & $\begin{array}{l}\text { Sand gravel, sandy gravel. Water level } 320.42 \mathrm{ft}, 3 / 30 / 90 \text {. } \\
\text { Yellowish brown (10YR5/4) 50-60\% fine to coarse } \\
\text { gravel and angular chips from cobbles, } 40 \% \text { medium } \\
\text { to coarse-grained to sub to angular sands, moderately } \\
\text { weathered. Fragments } 50 \% \text { quartz and quartzite, } 40 \% \\
\text { metamorphic rocks, } 10 \% \text { other rocks. Rig chatter from } \\
364 \mathrm{ft} \text {. }\end{array}$ \\
\hline
\end{tabular}

G\&M Inc 601

112.78

G\&M Inc 601

G\&M Inc 601

G\&M Inc 601

120.40

121.92

sand and gravel

G\&M Inc 601

121.92

122.83

sand and gravel
Sandy gravel. At $370 \mathrm{ft}, \approx 70 \%$ fine to coarse gravel $30 \%$ coarse sand, minor fines. Fragments $70 \%$ quartzite and quartzite, $20 \%$ volcanic rocks, $10 \%$ metamorphic rocks, start of large gravel at $370 \mathrm{ft}$. Heavy rig chatter from $370 \mathrm{ft}$.

At $380 \mathrm{ft}$, finer gravel, more rounded, plenty of cobble chips. Cobble/gravel $80 \%$, coarse sand $20 \%$. Fragments $75 \%$ quartz and quartzite, $20 \%$ volcanic rocks, $5 \%$ other metamorphic rocks. At $385 \mathrm{ft}$ water level $320.26 \mathrm{ft}$, 3/30/90.

At $390 \mathrm{ft}$, larger, angular gravel and cobble fragments. More quartzite less quartz.

At $395 \mathrm{ft}$, medium to strong weathering quartz, and quartzite and metamorphic rocks fragments to medium to coarse-grained sand. Rig chatter at 396-420 ft slow drilling quartz/quartzite. Cobbles/gravel.

No samples. Driller note, soft drilling 402-403 ft. From $403 \mathrm{ft}$, less rig chatter, smoother and faster drilling, some hard spots. 
Appendix 1. Compilation of borehole and aquifer data.-Continued

[cm, centimeter; $\mathrm{m}$, meter; in, inch; ft, feet; \%, percent; ppm, parts per million; $\approx$, approximately equal to; >, greater than]

\begin{tabular}{|c|c|c|c|c|}
\hline Bore & $\begin{array}{l}\text { Top } \\
\text { (m) }\end{array}$ & $\begin{array}{c}\text { Bottom } \\
\text { (m) }\end{array}$ & Simplified lithology & Driller's description \\
\hline G\&M Inc 601 & 122.83 & 124.97 & sand and trace gravel & $\begin{array}{l}\text { Gravelly sand, gravelly sand. Water level } 320.57 \mathrm{ft} \text {, } \\
3 / 30 / 90 \text {. Dark yellowish brown (10YR4/4) } 90 \% \text { medium } \\
\text { to coarse-grained sand, } 10 \% \text { fine to medium gravel } \\
\text { (cobbles. Subrounded to angular, weak to moderately } \\
\text { weathered. Fragments } 80 \% \text { quartz and quartzite, } 10 \% \\
\text { metamorphic rocks, } 5 \% \text { other rock. Light rig chatter } \\
406-408 \mathrm{ft} \text {, slow drilling. }\end{array}$ \\
\hline
\end{tabular}

G\&M Inc $601 \quad 124.97 \quad 126.49 \quad$ sand and trace gravel

G\&M Inc 601

126.49

128.02

sand and trace gravel

G\&M Inc 602

0.00

3.05

sand and trace gravel

G\&M Inc 602

G\&M Inc 602

G\&M Inc 602

7.62

15.24

sand and trace gravel

G\&M Inc 602

15.24

16.76

sand and trace gravel

G\&M Inc 602
4.57 sand and trace gravel

7.62 sand and gravel

Gravelly sand, gravelly sand, dark reddish brown (5YR3/4) $80 \%$ medium to coarse-grained sand, $20 \%$ fine gravel, not cemented. Fragments, 60\% quartzite and quartz 30\% volcanic rocks and $10 \%$ other rocks.

Gravelly sand, gravelly sand, brown (10YR5/3) 85\% medium to coarse-grained sand, $15 \%$ fine gravel. Fragments $60 \%$ metamorphic volcanic rocks, $30 \%$ quartzite and quartz $10 \%$ others, medium weathered and rounded gravel.

Gravelly sand, gravelly sand, reddish brown (5YR5/4) 75\% coarse to medium-grained sand and $25 \%$ fine-grained gravel, (subrounded). Fragments, $80 \%$ meta-volcanic rocks, $20 \%$ quartzite and quartz. Partially cemented sands and gravel fragments. 
Appendix 1. Compilation of borehole and aquifer data.-Continued

[cm, centimeter; m, meter; in, inch; ft, feet; \%, percent; ppm, parts per million; $\approx$, approximately equal to; $>$, greater than]

\begin{tabular}{|c|c|c|c|c|}
\hline Bore & $\begin{array}{l}\text { Top } \\
\text { (m) }\end{array}$ & $\begin{array}{c}\text { Bottom } \\
\text { (m) }\end{array}$ & Simplified lithology & Driller's description \\
\hline G\&M Inc 602 & 21.34 & 22.86 & sand and trace gravel & $\begin{array}{l}\text { Gravelly sand, gravelly sand, reddish brown (5YR5/3) } 80 \% \\
\text { medium to coarse-grained sand and } 20 \% \text { fine gravel. } \\
\text { Partially cemented. Fragments, } 90 \% \text { volcanic and meta- } \\
\text { volcanic rocks. } 10 \% \text { quartz and quartzite. }\end{array}$ \\
\hline G\&M Inc 602 & 22.86 & 24.38 & sand and trace gravel & $\begin{array}{l}\text { Gravelly sand, well graded sand, brown }(7.5 \text { YR5 } 5 / 4) 95 \% \\
\text { fine to medium-grained, well-graded sand, } 5 \% \text { fine- } \\
\text { grained gravel. Fragments } 90 \% \text { volcanic and metamor- } \\
\text { phic volcanic rocks, } 10 \% \text { quartzite and quartz. Partially } \\
\text { cemented, moderately weathered. }\end{array}$ \\
\hline
\end{tabular}

G\&M Inc 602

24.38

28.96

sand and trace gravel

G\&M Inc 602

G\&M Inc 602

G\&M Inc 602

G\&M Inc 602

36.58

G\&M Inc 602

38.10

41.15

G\&M Inc 602
38.10

sand and trace gravel

sand and clay

32.61

sand and trace gravel

36.58 sand and gravel

and, clay and trace gravel
Gravelly sand, gravelly sand/gravel, little or no fines, brown (7.5YR5/4) 75\% fine to coarse sand, 25\% fine gravel. Fragments of $70 \%$ volcanic and meta-volcanic rocks, $25 \%$ quartzite and quartzite and $5 \%$ cherty fragments, moderately weathered.

Gravelly sand, gravelly sand, brown (7.5YR $5 / 2) 90 \%$ fine to medium-grained sand, $5-10 \%$ fine gravel, $0-5 \%$ fines. Fragments $90 \%$ volcanic rocks, $10 \%$ quartz and other fragments. Moderately weathered.

Gravelly sand, gravelly sand, brown (7.5YR4/2) 80\% fine to coarse-grained sand, $15 \%$ fine gravel, $5 \%$ fines. Fragments $60 \%$ volcanic rocks, rocks, $30 \%$ quartz and quartzite, $10 \%$ other. Partially cemented, moderately weathered.

Gravell sand, gravelly sand, brown (7.5YR4/2) 80\% fine to coarse-grained sand, 15\% fine gravel, 5\% fines. Fragments $60 \%$ volcanic rocks, $30 \%$ quartz and quartzite, $10 \%$ other. Partially cemented, moderately weathered.

Gravelly sand, gravelly sand, light brown (7.5YR6/4) 80\% fine to coarse-grained sand, $10 \%$ fine gravel, $10 \%$ fines. Fragments, 50\% volcanic and meta-volcanic rocks, $40 \%$ quartz, and quartzite, $60 \%$ other metamorphic rocks. Partially cemented, moderately weathered.

Clayey sand, sandy clay, pale brown (10YR6/3) 80\% fine to medium-grained sand, $10 \%$ fine gravel, $10 \%$ fines. Partially cemented. Fragments $50 \%$ quartz and quartzite, $40 \%$ volcanic, $10 \%$ other rocks. At $130 \mathrm{ft}$ fines decrease to $\approx 5 \%$.

Brown (10YR5/5) 85\% fine to coarse-grained sand, 10\% fine gravel, (angular to subrounded), 5\% fines. Fragments $60 \%$ quartz site, $30 \%$ volcanic rocks, $10 \%$ others. At $140 \mathrm{ft}$, gravel reduced to $5 \%$ and sand is fine to medium-grained. 
Appendix 1. Compilation of borehole and aquifer data.-Continued

[cm, centimeter; $\mathrm{m}$, meter; in, inch; ft, feet; \%, percent; ppm, parts per million; $\approx$, approximately equal to; >, greater than]

\begin{tabular}{|c|c|c|c|c|}
\hline Bore & $\begin{array}{l}\text { Top } \\
\text { (m) }\end{array}$ & $\begin{array}{c}\text { Bottom } \\
\text { (m) }\end{array}$ & Simplified lithology & Driller's description \\
\hline G\&M Inc 602 & 42.67 & 45.72 & sand and trace gravel & $\begin{array}{l}\text { Gravelly sand, gravelly sand. Reddish brown }(5 \mathrm{YR} / 3) \\
75 \% \text { fine to coarse-grained sands, } 25 \% \text { fine to medium- } \\
\text { grained gravelly (rounded to subrounded). Fragments } \\
50 \% \text { quartzite. } 40 \% \text { volcanic rocks, } 10 \% \text { other metamor- } \\
\text { phic rocks. Partially cemented, moderately weathered. }\end{array}$ \\
\hline
\end{tabular}

G\&M Inc 602

45.72

50.29

sand and trace gravel

G\&M Inc 602

50.29

51.82

sand and gravel

G\&M Inc 602

51.82

54.86

sand and trace gravel

G\&M Inc 602

G\&M Inc 602

56.39

59.44

sand and trace gravel

G\&M Inc 602

59.44

62.48

sand and gravel

G\&M Inc 602

62.48

70.10

sand and trace gravel
Gravelly sand, gravelly sand. Reddish brown (5YR5/3) $75 \%$ fine to coarse-grained sands, $25 \%$ fine to mediumgrained gravel (rounded to subrounded). Fragments 50\% quartzite, $40 \%$ volcanic rocks, $10 \%$ other metamorphic rocks. Partially cemented, moderately weathered. At $155 \mathrm{ft}$, gravel reduced to $15 \%$, sand is fine to mediumgrained, 5\% fines (clay). At $160 \mathrm{ft}$, angular to subangular gravel to $25-30 \%$, sands medium to fine-grained.

Sand, well graded sand, brown (7.5YR5/2), 95\% fine to medium-grained, well graded sand with $\approx 5 \%$ fines sand garnets, $60-75 \%$ quartzite and quartz, $20-30 \%$ volcanic, $10 \%$ other rocks moderately weathered.

Gravelly sand, gravelly sand, light brown (7.5YR6/4) 70\% medium to coarse sand, $25 \%$ fine to medium subangular gravel 5\% fines, weakly weathered. At $175 \mathrm{ft}$, gravel reduced to $10-15 \%$ and fines (clay) increased to $10 \%$, rig chatter at $\approx 178 \mathrm{ft}$.

At $180 \mathrm{ft}$, gravel increased to $25 \%$ with $10 \%$ (clay) fines. Probable cobbles with gravel, rig chatter.

At $185 \mathrm{ft}$ sand and gravel fragment (cobble fragments) are $70 \%$ volcanic rocks (some welded and silicified), $25 \%$ quartzite and quartz and $5 \%$ other rocks, less rig chatter.

At $190 \mathrm{ft}$, gravel angular to subrounded increases to $\approx 35 \%$ sand partially cemented, sand fine to coarse-grained.

Gravelly sand, gravelly sand, pinkish gray (7.5YR6/2) 60\% medium to coarse-grained sand, $40 \%$ fine to mediumgrained gravel, (angular to subrounded). Fragments $60 \%$ volcanic rocks and cherty volcanic rocks, $35 \%$ quartz and quartzite, $5 \%$ other rocks, weakly weathered. At $210 \mathrm{ft}$, rig chatter, angular, chert, volcanic rocks, fragment 5-10\% fines (clay). At $215 \mathrm{ft}$, gravel reduce to $25 \%$ subangular to subrounded fragments. At $225 \mathrm{ft}$, $80 \%$ medium to coarse-grained sand and $15 \%$ finegrained, subangular gravel, 5\% fines (clay). 
Appendix 1. Compilation of borehole and aquifer data.-Continued

[cm, centimeter; m, meter; in, inch; ft, feet; \%, percent; ppm, parts per million; $\approx$, approximately equal to; $>$, greater than]

\begin{tabular}{|c|c|c|c|c|}
\hline Bore & $\begin{array}{l}\text { Top } \\
(\mathrm{m})\end{array}$ & $\begin{array}{l}\text { Bottom } \\
(\mathrm{m})\end{array}$ & Simplified lithology & Driller's description \\
\hline G\&M Inc 602 & 70.10 & 73.15 & sand, clay and gravel & $\begin{array}{l}\text { Gravelly sand, gravelly sand, brown }(7.5 \mathrm{YR} 5 / 4) 70 \% \text { fine } \\
\text { to coarse to-grained sand, } 20 \% \text { fine to coarse-grained } \\
\text { gravel, } 10 \% \text { fines (silts). Fragments } 50 \% \text { quartzite and } \\
\text { quartz, } 40 \% \text { volcanic rocks, } 10 \% \text { other rocks, moder- } \\
\text { ately weathered. }\end{array}$ \\
\hline G\&M Inc 602 & 74.68 & 76.20 & $\begin{array}{l}\text { sand, clay and trace } \\
\text { gravel }\end{array}$ & $\begin{array}{l}\text { At } 245 \mathrm{ft} \text {, medium to coarse gravel, rounded to angular in- } \\
\text { creases to } 40 \% \text { in medium-grained sand with } 10 \% \text { fines } \\
\text { (silts), gravel fragments of volcanic rocks and minor } \\
\text { metamorphic rocks. }\end{array}$ \\
\hline G\&M Inc 602 & 77.72 & 79.25 & sand and gravel & $\begin{array}{l}\text { At } 255 \mathrm{ft} \text {, increase in fine to coarse gravel (subangular to } \\
\text { subrounded to } 30 \% \text { in medium to coarse-grained sand. } \\
\text { Rig chatter at } 256 \mathrm{ft} \text {. }\end{array}$ \\
\hline G\&M Inc 602 & 79.25 & 80.77 & sand and gravel & $\begin{array}{l}\text { Gravelly sand, at } 260 \mathrm{ft} \text {, gravel increase in } 40 \% \text { (subround- } \\
\text { ed) in coarse-grained sand. }\end{array}$ \\
\hline G\&M Inc 602 & 83.82 & 86.87 & sand and gravel & $\begin{array}{l}\text { At } 275 \mathrm{ft} \text {, gravel reduced to } 10 \% \text { (fine) in medium to } \\
\text { coarse sand. At } 280 \mathrm{ft} \text { gravelly sand. }\end{array}$ \\
\hline G\&M Inc 602 & 86.87 & 88.39 & sand and gravel & $\begin{array}{l}\text { At } 285 \mathrm{ft}, 90 \% \text { medium to coarse-grained sand and }<10 \% \\
\text { fine gravel. }\end{array}$ \\
\hline G\&M Inc 602 & 88.39 & 89.92 & sand and gravel & $\begin{array}{l}\text { At } 290 \mathrm{ft} \text {, minor }(<10 \%) \text { fine gravel in medium to coarse- } \\
\text { grained sands. }\end{array}$ \\
\hline G\&M Inc 602 & 89.92 & 91.44 & sand and gravel & $\begin{array}{l}\text { At } 295 \mathrm{ft}, 20-30 \% \text { coarse, well-rounded, gravel in fine to } \\
\text { medium-grained sand, } 10 \% \text { fines. }\end{array}$ \\
\hline G\&M Inc 602 & 91.44 & 92.96 & sand and gravel & At $300 \mathrm{ft}, \approx 10 \%$ fine gravel in fine to coarse sand. \\
\hline
\end{tabular}


Appendix 1. Compilation of borehole and aquifer data.-Continued

[cm, centimeter; $\mathrm{m}$, meter; in, inch; $\mathrm{ft}$, feet; $\%$, percent; ppm, parts per million; $\approx$, approximately equal to; >, greater than]

\begin{tabular}{|c|c|c|c|c|}
\hline Bore & $\begin{array}{l}\text { Top } \\
(\mathrm{m})\end{array}$ & $\begin{array}{c}\text { Bottom } \\
(\mathrm{m})\end{array}$ & Simplified lithology & Driller's description \\
\hline G\&M Inc 602 & 92.96 & 94.49 & sand, clay and gravel & $\begin{array}{l}\text { At } 305 \mathrm{ft}, 20-30 \% \text { coarse, well-rounded gravel with fine to } \\
\text { medium-grained sand and } \approx 10 \% \text { fines (silts). }\end{array}$ \\
\hline G\&M Inc 602 & 94.49 & 97.54 & sand and clay & $\begin{array}{l}\text { Silty sand, silty sands, light brown ( } 7.5 \text { YR6/4) } 70 \% \text { fine- } \\
\text { grained sand, 30\% silty clay, sticky clay, more silt than } \\
\text { clay. }\end{array}$ \\
\hline G\&M Inc 602 & 97.54 & 99.06 & sand and clay & Water level $295.8 \mathrm{ft}, 3 / 1 / 80$. \\
\hline G\&M Inc 602 & 99.06 & 100.58 & sand and clay & $\begin{array}{l}\text { Silty sand, silty sands, very pale brown }(10 \mathrm{YR} 2 / 3) 80 \% \\
\text { fine-grained sand, } 10 \% \text { clayey silt fines, } 10 \% \text { coarse } \\
\text { sand fragments. }\end{array}$ \\
\hline G\&M Inc 602 & 103.63 & 105.16 & sand and clay & $\begin{array}{l}\text { At } 340 \mathrm{ft}, 5-10 \% \text { medium to coarse-grained sand } \\
\text { fragments. }\end{array}$ \\
\hline G\&M Inc 602 & 105.16 & 106.68 & sand and gravel & $\begin{array}{l}\text { At } 345 \mathrm{ft} \text { (light rig chatter) } 10 \% \text { angular, coarse sand frag- } \\
\text { ments (cobbles). }\end{array}$ \\
\hline G\&M Inc 602 & 106.68 & 108.20 & $\begin{array}{l}\text { sand, clay and trace } \\
\text { gravel }\end{array}$ & $\begin{array}{l}\text { Silty sand, silty sands. Water level } 330.1 \mathrm{ft}, 3 / 2 / 90 \text { light } \\
\text { brown ( } 7.5 \mathrm{YR} 6 / 4) 80 \% \text { fine-grained sand, } 10 \% \text { coarse- } \\
\text { grained sand (rounded to subangular), 10\% fine (silt), } \\
\text { moderately weathered. }\end{array}$ \\
\hline G\&M Inc 602 & 109.73 & 111.25 & sand and trace gravel & $\begin{array}{l}\text { Gravelly sand, gravelly sand, water level } 329.8,3 / 2 / 90 \text {. } \\
\text { Brownish yellow (10YR6/6) } 80 \% \text { fine to coarse sand, } \\
10 \% \text { fine gravel, } 10 \% \text { fines, moderately weathered. Frag- } \\
\text { ments } 40 \% \text { quartz and quartzite, } 60 \% \text { other metamorphic } \\
\text { rocks. }\end{array}$ \\
\hline G\&M Inc 602 & 111.25 & 112.78 & sand, clay and gravel & $\begin{array}{l}\text { Gravelly sand, gravelly sand, water level } 321.17 \mathrm{ft}, 3 / 3 / 90 \text {. } \\
\text { Light yellowish brown (10YR6/4) } 70 \% \text { fine to coarse- } \\
\text { grained sand, } 25 \% \text { fine to medium-grained gravel } \\
\text { and gravel fragments (angular) and } 5 \% \text { fines (silty). } \\
\text { Fragments } 70 \% \text { quartz and quartzite, } 20 \% \text { metamorphic } \\
\text { rocks, } 10 \% \text { other rocks, moderately weathered, possible } \\
\text { cobbles in drilling, rig chatter and drilling slow. At } 370 \\
\text { water level } 332.55 \mathrm{ft}, 3 / 3 / 90 \text {. }\end{array}$ \\
\hline
\end{tabular}


Appendix 1. Compilation of borehole and aquifer data.-Continued

[cm, centimeter; m, meter; in, inch; ft, feet; \%, percent; ppm, parts per million; $\approx$, approximately equal to; $>$, greater than]

\begin{tabular}{|c|c|c|c|c|}
\hline Bore & $\begin{array}{l}\text { Top } \\
\text { (m) }\end{array}$ & $\begin{array}{c}\text { Bottom } \\
\text { (m) }\end{array}$ & Simplified lithology & Driller's description \\
\hline G\&M Inc 602 & 112.78 & 114.30 & sand, clay and gravel & $\begin{array}{l}\text { Sandy gravel, sandy gravel, water level } 330.3 \mathrm{ft}, 3 / 3 / 90 \text {. } \\
\text { Very pale brown (10YR7/4) } 75 \% \text { fine to coarse gravel, } \\
20 \% \text { medium to coarse sand, percent (silty) fines. Frag- } \\
\text { ments } 90 \% \text { quartz and quartzite } 10 \% \text { other metamorphic } \\
\text { rocks, moderately weathered, some cemented fragments } \\
\text { (rig chatter, slow hard drilling. }\end{array}$ \\
\hline
\end{tabular}

G\&M Inc 602

114.30

117.35

sand and gravel

G\&M Inc 602

117.35

118.87

sand, clay and gravel

G\&M Inc 602

118.87

120.40

sand, clay and gravel

G\&M Inc 602

120.40

121.92

sand, clay and gravel

G\&M Inc 602

121.92

124.97

sand, clay and gravel

G\&M Inc 602

124.97

126.49

sand, clay and trace gravel

G\&M Inc 602

126.49

127.86

sand, clay and gravel
Water level $325.82 \mathrm{ft}, 3 / 3 / 90$. At $375-60 \%$ fine to coarse gravel and medium to coarse sand increases to $40 \%$. At $380 \mathrm{ft}$, angular fragments from cobbles, rig chatter continues.

Water level $324.1 \mathrm{ft}, 3 / 4 / 90$. At $385 \mathrm{ft}, 75 \%$ fine to coarse gravel, $20 \%$ fine to coarse sands and 5\% fines, hard drilling, lots of rig chatter, especially $380-383 \mathrm{ft}$.

At $390 \mathrm{ft}, 80 \%$ fine to coarse gravel and cobbles (?), 15\% coarse sand, $5 \%$ silty fines, quartz and quartzite fragments $\approx 80 \%$, very hard, slow drilling, lots of rig chatter. Water level $325.2 \mathrm{ft}, 3 / 4 / 90$.

Gravelly, sand, gravelly sand. Water level $324.18 \mathrm{ft}, 3 / 5 / 90$. Light yellowish brown (10YR6/4), 70\% medium to coarse-grained sand, $20 \%$ fine gravel, $\approx 10 \%$ fines (silty clay). Fragments $60 \%$ quartz and quartzite and $40 \%$ other metamorphic rocks, moderately weathered.

Water level $327.2 \mathrm{ft}, 3 / 5 / 90$. At $400 \mathrm{ft}$ continued gravelly sand, $60 \%$ medium to coarse-grained sand, $30 \%$ fine gravel, 10\% fines (clayey silts). Fragments $90 \%$ quartz and quartzite $10 \%$ other metamorphic rocks, hard slow drilling, light rig chatter and rod hop. At $405 \mathrm{ft}, 70 \%$ medium to coarse sand, $20 \%$ fine gravel, $10 \%$ fines.

Gravelly sand, gravelly sand, water level $\approx 327.7 \mathrm{ft}, 3 / 5 / 90$. Very pale brown (10YR7/3) 80\% medium to coarsegrained sand, $10 \%$ fine-grained gravel, $10 \%$ fines (silty clay), partially cemented. Fragments $85 \%$, quartz and quartzite, $10 \%$ other metamorphic rocks, $5 \%$ volcanic, very slow, hard drilling, moderate rig chatter and rod hop, possible drilling of quartz cobbles and gravel. Water level $\approx 325.0,3 / 6 / 90$.

Gravelly sand, gravelly sand, water level $\approx 328.12,3 / 18 / 90$. Pale brown (10YR6/3) 70\% medium to coarse-grained sand, $25 \%$ fine to coarse gravel, $5 \%$ fines (silty clay), weakly weathered. Fragments $90 \%$ quartz and quartzite, $10 \%$ other metamorphic rocks. 
Appendix 1. Compilation of borehole and aquifer data.-Continued

[cm, centimeter; $\mathrm{m}$, meter; in, inch; $\mathrm{ft}$, feet; \%, percent; ppm, parts per million; $\approx$, approximately equal to; >, greater than]

\begin{tabular}{|c|c|c|c|c|}
\hline Bore & $\begin{array}{l}\text { Top } \\
\text { (m) }\end{array}$ & $\begin{array}{c}\text { Bottom } \\
\text { (m) }\end{array}$ & Simplified lithology & Driller's description \\
\hline G\&M Inc 602 & 127.86 & 128.02 & sand and trace gravel & $\begin{array}{l}\text { Total depth, sand, well graded sand, light brownish gray } \\
\text { (10YR6/2) } 90 \% \text { plus fine to medium-grained sand, }<5 \% \\
\text { coarse-grained sand and gravel. }<5 \% \text { fines, well rounded } \\
\text { to subrounded, weakly weathered, sand } 90 \% \text { quartz and } \\
\text { quartzite, } 10 \% \text { other metamorphic rocks. }\end{array}$ \\
\hline
\end{tabular}

G\&M Inc 603

G\&M Inc 603

11.89

15.54

sand and trace gravel

G\&M Inc 603

15.54

25.30

sand and trace gravel

G\&M Inc 603

25.30

32.00

sand, clay and gravel

G\&M Inc 603

32.00

36.88

sand, clay and gravel

G\&M Inc 603

36.88

39.62

sand, clay and gravel

G\&M Inc 603

39.62

51.82

sand, clay and gravel

G\&M Inc 603

$51.82 \quad 53.34 \quad$ clay, sand and gravel

G\&M Inc 603
54.86 sand and clay
No data.

Sand, gravelly sand, medium to coarse sand mixed, color, primarily reddish brown (5YR5/4). At $45 \mathrm{ft}$ same with some (30\%) fine angular gravel. At $47 \mathrm{ft}$ hard drilling, cobbles $48 \mathrm{ft}$.

Sand, gravelly sand, Coarse sand with some 1/4 in subrounded gravel, light brownish gray 2.5YR (6/2). At 55 $\mathrm{ft}$ Coarse sand, little fine angular gravel, reddish brown (5YR5/4). At $65 \mathrm{ft}$ little 1/4-1/2 in gravel. At $70 \mathrm{ft}$ increased gravel, subrounded (20\%).

Silty gravel, hard drilling, cobbles $1 / 4-1 / 2$ in gravel, subrounded, silty fine to coarse sand, poorly sorted, HNU reading after sitting 30 minutes. At $90 \mathrm{ft}$ fine to coarse sand (40\%) $1 / 4-1 / 2$ in gravel (60\%) brown (7.5YR5/2). At $99 \mathrm{ft}$ silty fine to coarse sand $30 \% 1 / 4-1 / 2$ in subrounded gravel $(70 \%)$ brown $(7.5 \mathrm{YR} 5 / 2)$.

sand, silty sands, silty fine to coarse sand (60\%), 40\% $1 / 4$ in gravel brown (7.5YR5/4). At $109 \mathrm{ft}$ silty fine to coarse sand (70\%) 1/8-1/4 in gravel subrounded (30\%). At $115 \mathrm{ft}$ some clay.

Clayey sand, sandy clay, silty-clayey fine to coarse sand, $20-30 \%, 1 / 4-1 / 2$ in subrounded gravel, brown (7.5YR5/4). At $125 \mathrm{ft}$ harder drilling 60\% 1/4-1/2 in gravel.

Sand. gravelly sand, silty fine to coarse sand $30 \%$ $1 / 4-1 / 2$ in subrounded gravel, reddish brown (5YR4/3), at $135 \mathrm{ft}$ trace clay, $1 / 3-1 / 2$ in gravel (40\%). At $145 \mathrm{ft}$ silty fine to coarse sand, $1 / 4$ in gravel, subangular (10\%).

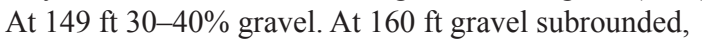
trace clay. At $165 \mathrm{ft} 20 \%$ gravel.

Clayey gravel, sandy clay gravel, clayey gravel, 1/4-1/2 in subrounded $40 \%$ medium to coarse sand, brown (7.5YR5/4).

Clayey sand, sandy clay. Clayey fine to coarse sand, 10\% $1 / 4-1 / 2$ in gravel. 
Appendix 1. Compilation of borehole and aquifer data.-Continued

[cm, centimeter; m, meter; in, inch; ft, feet; \%, percent; ppm, parts per million; $\approx$, approximately equal to; >, greater than]

\begin{tabular}{|c|c|c|c|c|}
\hline Bore & $\begin{array}{l}\text { Top } \\
\text { (m) }\end{array}$ & $\begin{array}{l}\text { Bottom } \\
\text { (m) }\end{array}$ & Simplified lithology & Driller's description \\
\hline G\&M Inc 603 & 54.86 & 56.39 & clay, sand and gravel & $\begin{array}{l}\text { Clayey gravel, sandy clay gravel. Clayey gravel } \\
1 / 4-1 / 2 \text { in subangular } 30-40 \% \text { fine to coarse sand brown } \\
(7.5 \text { YR } 5 / 4) \text {. }\end{array}$ \\
\hline G\&M Inc 603 & 56.39 & 57.91 & clay and sand & $\begin{array}{l}\text { Clayey, sand, sandy clay. Clayey fine in coarse sand } \\
10-15 \% 1 / 4-1 / 2 \text { in gravel. }\end{array}$ \\
\hline G\&M Inc 603 & 57.91 & 70.10 & $\begin{array}{l}\text { sand, clay and trace } \\
\text { gravel }\end{array}$ & $\begin{array}{l}\text { Silty sand, silty sands. Silty fine to medium sand trace, } 5 \% \\
1 / 4 \text { in subrounded gravel, brown. At } 195 \mathrm{ft} \text { silty medium } \\
\text { to coarse sand } 40 \% 1 / 4-1 \text { in subrounded gravel, hard } \\
\text { drilling. At } 201 \mathrm{ft} \text { silty fine to coarse sand } 30 \% \text { suban- } \\
\text { gular } 1 / 4-3 / 4 \text { in gravel brown }(7.5 \mathrm{YR} 5 / 4) \text { poorly sorted. } \\
\text { At } 209 \mathrm{ft} 30-40 \% \text { gravel. At } 215 \mathrm{ft} \text { silty fine to coarse } \\
\text { sand } 10 \% 1 / 4 \text { in subangular gravel brown }(7.5 \mathrm{YR} 5 / 4) \text {. } \\
\text { At } 225 \mathrm{ft} \text { less gravel }(<5 \%) \text {, more fines, light brown } \\
\text { (7.5YR6/4). }\end{array}$ \\
\hline
\end{tabular}

G\&M Inc 603

G\&M Inc 603

G\&M Inc 603

G\&M Inc 603

80.16

97.84

sand, clay and gravel
Sand, gravelly sand, medium to coarse sand, trace fines, $40-50 \%$, subrounded, $1 / 4-3 / 4$ in gravel, some lighter colors, mostly brown $(7.5 \mathrm{YR} 5 / 4)$.

Silt sand, silty sands. Silty fine to coarse sand $40 \%$ subrounded, 1/4-3/4 in gravel, (7.5YR6/4) light brown. At $240 \mathrm{ft}$ silty fine to coarse sand trace $1 / 3-1 / 4$ in gravel, light brown (7.5YR6/4). At $244 \mathrm{ft} 20 \% 1 / 4-1 / 2$ in gravel subrounded. At $249 \mathrm{ft} 10 \% 1 / 4-1 / 2$ in gravel subrounded, slight increase in fines, cemented. At $254 \mathrm{ft}$ silty fine to coarse sand $30 \% 1 / 4-1 / 2$ in gravel subrounded, light brown (7.5YR6/5).

Sand, gravelly sand, fine to coarse sand, trace silt, $15 \%$ $1 / 8-1 / 2$ in gravel, brown, $(7.5 \mathrm{YR} 5 / 4)$.

Silt sand, silty sands, silty fine to coarse sand $10 \%$ $1 / 4-1 / 2$ in subangular gravel. At $269 \mathrm{ft} 20 \%$ gravel, subrounded. At $274 \mathrm{ft}$ same. At $279 \mathrm{ft}$ same. At $285 \mathrm{ft}$ silty sands, silty to coarse sand 20\% 1/4-3/4 in gravel subangular, brown (7.5YR5/4). At $291 \mathrm{ft}$ silty sands, silty medium to coarse sand trace $1 / 4$ in gravel, brown (7.5YR5/4). At $295 \mathrm{ft}$ increased gravel to $30-40 \%$ subrounded. At $298 \mathrm{ft}$, gravel 1/4-1/2 in subrounded (30\%). At $304 \mathrm{ft} \mathrm{10 \%} \mathrm{gravel.} \mathrm{At} 309 \mathrm{ft}$ increase fines, only trace gravel. At $314 \mathrm{ft}$ silty sands silty fine sand ( $40 \%$ silt) yellowish light brown (10YR5/3).

Silt, silt and very fine sand. Pale brown, sandy silt, trace $1 / 4$ in gravel, (10YR6/3). At $323 \mathrm{ft}$ water at $323.33 \mathrm{ft}$, 09:01. At $329 \mathrm{ft}$ reddish brown (5YR5/4). At $334 \mathrm{ft}$ trace clay. 
Appendix 1. Compilation of borehole and aquifer data.-Continued

[cm, centimeter; $\mathrm{m}$, meter; in, inch; ft, feet; \%, percent; ppm, parts per million; $\approx$, approximately equal to; >, greater than]

\begin{tabular}{ccccc}
\hline Bore & $\begin{array}{c}\text { Top } \\
(\mathbf{m})\end{array}$ & $\begin{array}{c}\text { Bottom } \\
(\mathbf{m})\end{array}$ & Simplified lithology & Driller's description \\
\hline G\&M Inc 603 & 103.33 & 104.55 & $\begin{array}{c}\text { sand, clay and trace } \\
\text { gravel }\end{array}$ & $\begin{array}{c}\text { Silty sand, silty sands, light yellowish brown }(10 Y R 6 / 4) \\
\text { silty sand/sandy silt, trace gravel and siltstone cobbles } \\
\text { at } 343 \mathrm{ft} .\end{array}$ \\
G\&M Inc 603 & 104.55 & 108.20 & sand, clay and gravel & $\begin{array}{c}\text { Silt and very fine sand. Cemented silts and fine-grained } \\
\text { sandstone, 10-15\% coarse sand and gravel, pale brown } \\
\text { (10YR6/3) hard drilling. At 351 ft cobbles with some } \\
\text { coarse sand, heavy rig chatter. Easier at 354 ft. }\end{array}$
\end{tabular}

G\&M Inc 603

108.20

109.73

sand, clay and gravel

G\&M Inc 603

109.73

112.47

clay, sand and gravel

G\&M Inc 603

112.47

113.69

sand, clay and gravel

G\&M Inc 603

113.69

118.57

sand, clay and gravel

G\&M Inc 603

118.57

121.31

sand, clay and gravel

G\&M Inc 603

121.31

126.49

sand and gravel
Silty sands, silty medium to coarse sand, some subrounded $1 / 8-1 / 4$ in gravel $(20 \%)$ and trace of cobble fragments, brown $(7.5 \mathrm{YR} 5 / 4)$.

Silt, silt and very fine sand, silty with $20 \%$ medium to coarse sand and 20\% 1/8-1/4 in gravel, some clay light yellowish brown (10YR6/4). Rig chatter at $363 \mathrm{ft} \mathrm{At}$ $364 \mathrm{ft}$ sandy silty $30 \%$ fine to coarse sand and $10 \%$ $1 / 4-1$ in gravel, light yellowish brown (10YR5/3), occasional angular cobble, chips of varying color.

Water level -319.41 ft, 1/17/90. At $370 \mathrm{ft}$ occasional rig chatter, increased gravel 1/8-3/4 in, (40\%), gravelly silt, light yellowish brown (10YR5/3).

cobbles, cobbles, some coarse sand and silt (?). Color varies depending on individual cobble. Heavy rig chatter continues. At $379 \mathrm{ft}$ cobbles of various colors, trace of silt and fine to coarse sand, heavy rig chatter, very slow drilling. Water level $316.24 \mathrm{ft}, 1 / 17 / 90$. At $383 \mathrm{ft}$ cobbles with some fine to medium sand and cemented silt, light yellowish brown (10YR6/4).

Water level $375.93 \mathrm{ft}, 1 / 18 / 90$. Using cable tool below 390 coarse sand and gravel, some cobbles and large fragments of indurated silt and sand. Changed to cable tool at $390 \mathrm{ft}$.

At $401 \mathrm{ft}$ gravelly sand. Medium to coarse sand and some fine gravel, no coarse gravel in cuttings. At $404 \mathrm{ft}$ amount of cuttings in bailer decreasing. At $407 \mathrm{ft}$ gravelly sand, fine to medium sand, $1-2 \%$ coarse sand, trace fine gravel, water very muddy, only $2-4$ cups of cuttings in a bailer load. At $415 \mathrm{ft}$ water level $322.10 \mathrm{ft}, 2 / 3 / 90$. Total depth $415 \mathrm{ft}$ measured with cuttings bailer. 
Appendix 1. Compilation of borehole and aquifer data.-Continued

[cm, centimeter; m, meter; in, inch; ft, feet; \%, percent; ppm, parts per million; $\approx$, approximately equal to; $>$, greater than]

\begin{tabular}{|c|c|c|c|c|}
\hline Bore & $\begin{array}{l}\text { Top } \\
\text { (m) }\end{array}$ & $\begin{array}{c}\text { Bottom } \\
\text { (m) }\end{array}$ & Simplified lithology & Driller's description \\
\hline G\&M Inc 604 & 0.00 & 7.32 & sand, clay and gravel & $\begin{array}{l}\text { Silty sand, silty sands, at } 4 \mathrm{ft} \text {, brown silty sand } 30-40 \% \text {, } \\
1 / 4-1 / 2 \text { in gravel (10YR } 5 / 3) \text {, subrounded gravel. At } \\
14 \mathrm{ft} \text { Some cobbles of various color, increase in color, } \\
\text { increase in coarse sand. At } 19 \mathrm{ft} \text { fine to coarse silty sand, } \\
\text { trace } 1 / 4 \text { in subangular gravel, brown }(10 \mathrm{YR} 5 / 3) \text {. }\end{array}$ \\
\hline G\&M Inc 604 & 8.84 & 15.24 & sand and trace gravel & $\begin{array}{l}\text { Gravelly sand, gravelly sand } 40 \% \text { medium to coarse sand, } \\
\text { trace gravel to } 1 / 4 \text { in subrounded, cobble chips. At } \\
39 \mathrm{ft} \text { increased gravel }(20 \%) \text { and cobble chips. At } 45 \mathrm{ft} \\
\text { gravelly sand, gravelly sand, brown, }(7.5 \mathrm{YR} 5 / 4) 10 \% \\
\text { plasticity fines, } 25 \% \text { fine-coarse gravel, } 65 \% \text { fine to } \\
\text { coarse sand, Fe oxide staining on grains, abundant. }\end{array}$ \\
\hline G\&M Inc 604 & 15.24 & 21.34 & sand and gravel & $\begin{array}{l}\text { Sandy gravel, CP, brown ( } 7.5 \mathrm{YR} 5 / 4), 65 \% \text { fine to coarse } \\
\text { gravel, } 30 \% \text { fine to coarse sand subrounded, Fe oxide } \\
\text { staining on grains. At } 60 \mathrm{ft} \text { fines to } 10-15 \%, 30 \% \text { fine to } \\
\text { coarse sand, } 55-60 \% \text { gravel, Fe oxide staining on some } \\
\text { grains. At } 68 \% \text { gravel stringers. }\end{array}$ \\
\hline
\end{tabular}

G\&M Inc 604

G\&M Inc 604

G\&M Inc 604

G\&M Inc 604

G\&M Inc 604

G\&M Inc 604 sand and trace gravel

22.86

27.43

sand and gravel

27.43

30.48

sand, clay and gravel

30.48

31.39

sand and clay

31.39

33.53

sand and gravel

$33.53 \quad 35.05 \quad$ sand and clay

$35.05-36.58 \quad$ Gravel

Gravelly sand, gravelly sand, brown, (7.5YR5/4) 15\% low plasticity fines, $60 \%$ fine to coarse sand, $25 \%$ fine to coarse gravel.

Sandy gravel, sandy gravel. At $80 \mathrm{ft}$ sandy gravel, reddish brown $(5 \mathrm{YR} 4 / 3)$.

Silt sand, silty sands, reddish brown (7YR4/3) 20\% lowmod plasticity fines, $15 \%$ fine, coarse gravel, $65 \%$ fine to coarse sand. At $98 \mathrm{ft}$ gravel to $25 \%$.

Clayey sand, sandstone, reddish brown (5YR/4) 20\% moderate plasticity fines, $70 \%$ fines to coarse sand, $10 \%$ fine to coarse gravel.

Sandy gravel, sandy gravel, reddish brown (5YR5/4) 15\% moderate plasticity fines, $30 \%$ fine to coarse sand, $55 \%$ fine to coarse gravel.

Clayey sand, sandy clay, reddish brown (5YR5/4) 20-25\% moderate plasticity fines, $10 \%$ gravel, $65-70 \%$ sand.

Gravel Sandy gravel, reddish brown (5YR5/4). 
Appendix 1. Compilation of borehole and aquifer data.-Continued

[cm, centimeter; $\mathrm{m}$, meter; in, inch; $\mathrm{ft}$, feet; $\%$, percent; ppm, parts per million; $\approx$, approximately equal to; >, greater than]

\begin{tabular}{ccccc}
\hline Bore & $\begin{array}{c}\text { Top } \\
(\mathbf{m})\end{array}$ & $\begin{array}{c}\text { Bottom } \\
(\mathbf{m})\end{array}$ & Simplified lithology & Driller's description \\
\hline G\&M Inc 604 & 36.58 & 39.62 & sand, clay and gravel & $\begin{array}{c}\text { Silty gravel, silty gravel-sandy gravel, reddish brown, 15\% } \\
\text { low plasticity fines, } 10 \% \text { fine to coarse sand, } 75 \% \text { fine to } \\
\text { coarse sand, } 75 \% \text { fine to coarse gravel, Fe oxide staining } \\
\text { on grains, occasional cobbles. }\end{array}$ \\
\end{tabular}

G\&M Inc 604

G\&M Inc 604

G\&M Inc 604

G\&M Inc 604

G\&M Inc 604

G\&M Inc 604

G\&M Inc 604

G\&M Inc 604

G\&M Inc 604

G\&M Inc 604

G\&M Inc 604
39.62

42.67

sand, clay and gravel

$\begin{array}{lll}42.67 & 48.77 \quad \text { sand and gravel }\end{array}$

48.77

54.86

clay, sand and gravel

54.86

60.96

sand and clay

64.0

sand and gravel

$64.01 \quad 74.68 \quad$ sand and gravel

74.68

sand and gravel

88.39

91.44

sand and clay

$91.44 \quad 96.01 \quad$ sand and trace gravel

$96.01 \quad 97.54 \quad$ sand and clay
Silty sand to sand, silty sands-gravelly sand, reddish brown, $10-20 \%$ low plasticity fines, $60 \%$ fine to coarse sand, $20-30 \%$ fine to coarse gravel.

Sandy gravel, sandy gravel, reddish brown, $10 \%$ low plasticity fines, $30 \%$ fine to coarse sand, $60 \%$ fine to coarse gravel, Fe oxide staining on some grains occasional cobbles.

Clayey gravel, sandy clay gravel, reddish brown, 20\% moderate plasticity fines, $15 \%$ fine to coarse sand, $65 \%$ gravel and cobbles. At $164 \mathrm{ft} \mathrm{hard} \mathrm{streak.}$

Clayey sand, sandy clay, brown (7.5YR. 5/4) 20\% moderate plasticity fines, $60 \%$ fine to coarse sand, $20 \%$ gravel and cobbles. At $196 \mathrm{ft}$ cobbles.

Sandy gravel, sandy gravel, brown (7.5YR5/4), 10\% low plasticity fines, $30 \%$ fine to coarse sand, $60 \%$ gravel and cobbles.

Sandy gravel/gravelly sand, gravelly sand-CP, brown (7.5YR5/4), 10-15\% low plasticity fines, $40-50 \%$ sand, $40-50 \%$ gravel and cobbles.

Sandy gravel, sandy gravel, Gravel brown (7.5YR5/4), $10 \%$ low plasticity fines, $30 \%$ fine to coarse sand, $60 \%$ fine to coarse gravel, occasional cobbles.

Gravelly sand, gravelly sand, brown (7.5YR5/4), 10\% low plasticity fines, $70 \%$ sand, $20 \%$ gravel and cobbles. At $280 \mathrm{ft}$ gravelly sand.

Clayey sand, sandy clay, brown (7.5YR5/4) 20-25\% lowmoderate plasticity fines, $70-75 \%$ fine to medium sand, $\leq 10 \%$ gravel, stringers of cobbles.

Sand, gravelly sand, brown (7.5YR5/4) 10\% fines, 85\% fine to coarse sand, $5 \%$ gravel. At $308 \mathrm{ft}$ hard drilling.

Clayey sand, sandy clay, brown (7.5YR5/2) 20\% moderate plasticity fines, $70 \%$ sand, $10 \%$ gravel. 
Appendix 1. Compilation of borehole and aquifer data.-Continued

[cm, centimeter; m, meter; in, inch; ft, feet; \%, percent; ppm, parts per million; $\approx$, approximately equal to; $>$, greater than]

\begin{tabular}{|c|c|c|c|c|}
\hline Bore & $\begin{array}{l}\text { Top } \\
\text { (m) }\end{array}$ & $\begin{array}{c}\text { Bottom } \\
\text { (m) }\end{array}$ & Simplified lithology & Driller's description \\
\hline G\&M Inc 604 & 97.54 & 100.58 & sand and clay & Clayey sand, sandy clay, with stringers of gravel. \\
\hline G\&M Inc 604 & 100.58 & 102.11 & sand, clay and gravel & $\begin{array}{l}\text { Silty sand, gravelly sand-silty sands, very pale brown } \\
(10 \mathrm{YR} 8 / 3) \text { very fine to medium grain sand, well indu- } \\
\text { rated, friable } 30 \% \text { low plasticity fines, } 15 \% \text { gravel. }\end{array}$ \\
\hline G\&M Inc 604 & 102.11 & 102.72 & sand, clay and gravel & $\begin{array}{l}\text { Gravelly sand, gravelly sand, brown (10YR5/3) medium } \\
\text { to coarse-grained sand with silty clays, } 20-30 \% \text { gravel, } \\
\text { deeply weathered. }\end{array}$ \\
\hline G\&M Inc 604 & 102.72 & 105.16 & clay, sand and gravel & $\begin{array}{l}\text { Clayey gravel, sandy clay gravel, brown }(10 \mathrm{YR} 5 / 3) \\
10-40 \% \text { coarse sand, silty clays, } 50 \% \text { well graded } \\
\text { gravel, fragments of milky quartz, quartzite and green } \\
\text { metamorphic rocks. At } 344 \mathrm{ft} \text { water level } \approx 323.16 \mathrm{ft} \text {. }\end{array}$ \\
\hline G\&M Inc 604 & 105.16 & 106.68 & clay, sand and gravel & $\begin{array}{l}\text { Sandy silts, silt and very fine sand, light olive gray } \\
(5 \mathrm{YR} 6 / 2) \text { Static water at } 323.16 \mathrm{ft} \text { At } 347 \mathrm{ft} \text { clayey silt, } \\
\text { silt and very fine sand, light gray }(5 \mathrm{YR} 7 / 2) \text {. Fine-grained } \\
\text { clayey silt and minor }(<5 \%) \text {, gravelly sands. }\end{array}$ \\
\hline G\&M Inc 604 & 106.68 & 109.73 & sand and trace gravel & $\begin{array}{l}\text { sand, static water level } 322.9 \mathrm{ft} \text {, elevation } 2,447.05 \mathrm{ft}) \\
\text { well graded sands, brown }(7.5 \mathrm{YR} 5 / 4) \text { Fine to medium- } \\
\text { grained, well graded sand, } 3 \% \text { cobbles of milky to light } \\
\text { gray quartz sands } 30 \% \text { quartz, } 60 \% \text { feldspar, } 10 \% \text { other, } \\
\text { weakly weathered, well cemented. At } 356 \mathrm{ft} \text { introduc- } \\
\text { tion of cobbles of reddish brown, quartzite moderately } \\
\text { weathered. }\end{array}$ \\
\hline
\end{tabular}

G\&M Inc 604

G\&M Inc 604

G\&M Inc 604

G\&M Inc 604
$109.73 \quad 111.56 \quad$ sand, clay and gravel

111.56

112.17 sand, clay and gravel

$112.17 \quad 114.30 \quad$ sand and clay
Static water level $357.5 \mathrm{ft}$, elevation 2,412.45 ft. At $360 \mathrm{ft}$ sand cemented and mixed with 3-5\% fine to mediumgrained clayey gravel of moderately weathered quartzite and metamorphic rocks.

Silty gravel, silty gravel, brown (7.5YR5/4) fine-grained silts and $90 \%$ fine gravel, quartzite, quartz and metamorphic and volcanic rocks, weakly weathered.

Silty sand, silty sands, brown (7.5YR5/4) medium to coarse-grained sand and fine silt, fragments of quartz, quartzite, weakly weathered, and minor metamorphic rocks.

Silty sand, static water level $346.15 \mathrm{ft}$, elevation $2423.80 \mathrm{ft}$. Silty sands, brown $(7.5 \mathrm{YR} 5 / 4)$ fine to medium-grained, well graded sand, $10 \%$ quartz fragments/cobbles, well cemented, more silts than before. 
Appendix 1. Compilation of borehole and aquifer data.-Continued

[cm, centimeter; $\mathrm{m}$, meter; in, inch; $\mathrm{ft}$, feet; $\%$, percent; ppm, parts per million; $\approx$, approximately equal to; >, greater than]

\begin{tabular}{ccccc}
\hline Bore & $\begin{array}{c}\text { Top } \\
(\mathbf{m})\end{array}$ & $\begin{array}{c}\text { Bottom } \\
(\mathbf{m})\end{array}$ & Simplified lithology & Driller's description \\
\hline G\&M Inc 604 & 115.82 & 118.87 & sand and clay & $\begin{array}{c}\text { Silty sand, static water level } 374.25 \mathrm{ft} \text {, elevation } 2,395.70 . \\
\text { Silty sands, brown }(7.5 \mathrm{YR} 5 / 4) \text { fine to medium-grained } \\
\end{array}$ \\
& & & $\begin{array}{l}\text { sand with } \approx 5-15 \% \text { silts and clays, 50\% of sand is milky } \\
\text { with quartz fragments, poorly cemented. }\end{array}$
\end{tabular}

G\&M Inc $604 \quad 118.87 \quad 121.31 \quad$ sand and clay

G\&M Inc 604

G\&M Inc 604

G\&M Inc 604

G\&M Inc 604

G\&M Inc 604

G\&M Inc 604

129.84

131.06

sand and trace gravel

131.06

132.59
Silty sand, static water level $319.43 \mathrm{ft}$, elevation $2,450.52 \mathrm{ft}$. Silty sands, brown (7.5YR5/4) same as above, except more sand and silt (to $25 \%$ partially cemented sands.

Silty clay, clay, light brown (7.5YR6/4) fine silty clay, so $\mathrm{ft}$ At $400 \mathrm{ft}$ gravelly clay, clay, light brown (7.5YR6/4) fine-grained clay (soft), $\approx 10 \%$ fine-grained gravel of fragments of quartz and metamorphic rocks.

Clayey sand, sandy clay, brown (7.5YR6/4) medium to coarse sand and 10 clay and 1\% fine gravel, sand fragments of quartz, quartzite and metamorphic rocks.

Silty gravel, silty gravel, water level $\approx 367.25 \mathrm{ft}$, light reddish brown (5YR6/4) fine gravel, 5-10\% silts, gravel fragments $60 \%$ quartz, $30 \%$ quartzite and $10 \%$ metamorphic and other rocks. Rig chatter while drilling.

Gravelly sand, well graded sand, brown (7.5YR4/4), coarse sand $60 \%, 40 \%$ fine gravel, gravel fragments $50 \%$ reddish brown quartzite, $40 \%$ quartz, $10 \%$ other rocks, rig chatter.

Gravelly sand, water level $\approx 321.47 \mathrm{ft}$ well graded sands, reddish brown (5YR4/4) gravelly sand, 5\% silts, $80 \%$ coarse sands, $15 \%$ gravel, $80 \%$ reddish brown quartzite, $15 \%$ quartz, other rock deeply weathered, quartzite, moderate weathering on others. Rig chatter and hard drilling (415-427 ft).

Gravelly sand, well graded sand, pale brown (10YR6/3) medium to coarse-grained sand, 5-10\% fine gravel, fragments quartz, quartzite and metamorphic rocks.

Gravelly sand, water level $\approx 321.0 \mathrm{ft}$, well graded sand, light yellowish brown (10YR6/4) 80-85\% medium to coarse sand, $10-15 \%$ fine gravel, $5 \%$ silts, sand and gravel fragments of $20 \%$ quartz, $60 \%$ quartzite, $20 \%$ other metamorphic rocks. Very hard drilling 429-430 ft. 
Appendix 1. Compilation of borehole and aquifer data.-Continued

[cm, centimeter; m, meter; in, inch; ft, feet; \%, percent; ppm, parts per million; $\approx$, approximately equal to; $>$, greater than]

\begin{tabular}{|c|c|c|c|c|}
\hline Bore & $\begin{array}{l}\text { Top } \\
\text { (m) }\end{array}$ & $\begin{array}{c}\text { Bottom } \\
\text { (m) }\end{array}$ & Simplified lithology & Driller's description \\
\hline G\&M Inc 604 & 132.59 & 132.89 & sand and trace gravel & $\begin{array}{l}\text { Gravelly sand, water level } \approx 320.9 \mathrm{ft} \text {, well graded sand, pale } \\
\text { brown }(10 \text { YR6/3) } 80-90 \% \text { medium to coarser-grained } \\
\text { sand partially to uncemented, } 10-20 \% \text { fine to coarse } \\
\text { gravel. Fragments, } 50 \% \text { quartz, } 30 \% \text { quartzite, } 20 \% \\
\text { metamorphic rocks. Total depth } 436.2 \text { drilling completed } \\
\text { 2/20/90 }\end{array}$ \\
\hline G\&M Inc 605 & 5.79 & 13.72 & sand, clay and gravel & $\begin{array}{l}\text { Silty sands, silty sand and gravel }(1 / 8-1 / 2 \text { in) poorly sort- } \\
\text { ed, rounded, light brown. At } 42 \mathrm{ft} \text { gravelly sand, medium } \\
\text { to coarse sand, rounded, } 30 \% 1 / 4-1 / 2 \text { in angular gravel. }\end{array}$ \\
\hline
\end{tabular}

G\&M Inc 605

G\&M Inc 605

G\&M Inc 605

G\&M Inc 605

G\&M Inc 605

G\&M Inc 605
25.91

30.48

sand, clay and gravel

30.48

33.53

sand, clay and gravel

33.53

35.05

sand and clay

36.58

38.10

41.15

41.15
36.58

38.10

Sandy gravel, 1/4-1/2 in gravel, subrounded, 30\% silty, fine to coarse sand, poorly sorted. At $88 \mathrm{ft}$ sandy gravel, medium to coarse sand 30\% 1/4 in gravel, subrounded $70 \%$, brown $(7.5 \mathrm{YR} 5 / 2)$.

Silty sands, silty fine to coarse sand, $30 \% 1 / 4$ in gravel, $1 / 2$ in subrounded, brown (7.5YR5/4). At $104 \mathrm{ft}$, $1 / 4-1 / 2$ in gravel, $30 \%$ silty fine to coarse sand.

Silty sands-gravelly sand, Cemented silt and fine sand (10-20\% 80-90\% 1/8-1/2 in gravel, light brown (7.5YR6/4).

Sandy clay gravel, clayey sand gravel, 1/4-3/4 in.

Silty sands, clayey fine to coarse sand, $20-30 \% 1 / 4-1 / 2$ in gravel, subangular, brown (7.5YR5/4).

Gravelly sand-sandy gravel, $40-50 \% 1 / 4-1 / 2$ in gravel.

Gravelly sand, silty fine to coarse sand, 30\% 1/4-1/2 in gravel, subrounded, brown (7.5YR5/4). At $140 \mathrm{ft}$ gravelly sand, medium to coarse sand, subrounded, $20 \%$ $1 / 8-1 / 4$ in gravel, trace of clay, brown (7.5YR5/4). 
Appendix 1. Compilation of borehole and aquifer data.-Continued

[cm, centimeter; $\mathrm{m}$, meter; in, inch; $\mathrm{ft}$, feet; $\%$, percent; ppm, parts per million; $\approx$, approximately equal to; >, greater than]

\begin{tabular}{|c|c|c|c|c|}
\hline Bore & $\begin{array}{l}\text { Top } \\
\text { (m) }\end{array}$ & $\begin{array}{l}\text { Bottom } \\
(\mathrm{m})\end{array}$ & Simplified lithology & Driller's description \\
\hline G\&M Inc 605 & 45.72 & 47.24 & $\begin{array}{l}\text { sand, clay and trace } \\
\text { gravel }\end{array}$ & $\begin{array}{l}\text { Silty sands, silty fine to coarse sand, 5\% gravel, subangu- } \\
\text { lar, light brown (7.5YR6/4). }\end{array}$ \\
\hline G\&M Inc 605 & 47.24 & 48.77 & sand and gravel & $\begin{array}{l}\text { Sandy gravel, poorly sorted, } 1 / 4-1 \text { in gravel, subangular, } \\
30 \% \text { medium to coarse sand. }\end{array}$ \\
\hline G\&M Inc 605 & 48.77 & 53.64 & sand, clay and gravel & $\begin{array}{l}\text { Gravelly sand, silty fine to coarse sand, } 40 \% 1 / 4-1 / 2 \text { in } \\
\text { gravel, subrounded, brown }(7.5, \text { YR5/4). At } 165 \mathrm{ft} 20 \% \\
1 / 4 \text { in gravel. }\end{array}$ \\
\hline G\&M Inc 605 & 53.64 & 56.08 & sand, clay and gravel & $\begin{array}{l}\text { Sandy gravel-gravelly sand, clayey gravel, } 1 / 4-1 / 2 \mathrm{in}, 40 \% \\
\text { fine to coarse sand, subrounded, brown }(7.5 \text { YR } 5 / 4) \text {. }\end{array}$ \\
\hline G\&M Inc 605 & 57.91 & 60.96 & clay, sand and gravel & $\begin{array}{l}\text { Sandy clay-gravelly sand, clayey fine to coarse sand, } 20 \% \\
1 / 4-1 / 2 \text { in gravel, subrounded, brown }(7.5 \text { YR } 5 / 4) \text {. }\end{array}$ \\
\hline G\&M Inc 605 & 60.96 & 62.18 & clay, sand and gravel & $\begin{array}{l}\text { Gravelly sand, clayey fine to coarse sand, subangular } 1 / 2 \text { in } \\
\text { gravel, } 30 \% \text { brown }(7.5 \mathrm{YR} 5 / 4) \text {. }\end{array}$ \\
\hline G\&M Inc 605 & 62.18 & 65.23 & sand and gravel & $\begin{array}{l}\text { Sandy gravel, } 1 / 4-1 / 2 \text { in subrounded gravel, } 40 \% \text {, medium } \\
\text { to coarse sand, brown }(7.5 \text { YR } 5 / 4) \text {. }\end{array}$ \\
\hline G\&M Inc 605 & 68.28 & 70.10 & sand, clay and gravel & $\begin{array}{l}\text { Sandy gravel, } 1 / 4-1 \text { in subrounded gravel, } 30 \% \text { clayey } \\
\text { sand. }\end{array}$ \\
\hline G\&M Inc 605 & 70.10 & 73.15 & sand and gravel & $\begin{array}{l}\text { Gravelly sand, medium to coarse sand, } 40 \% 1 / 4-3 / 4 \text { in } \\
\text { gravel, subrounded, brown }(7.5 \text { YR } 5 / 4) \text {. }\end{array}$ \\
\hline G\&M Inc 605 & 73.15 & 74.68 & sand, clay and gravel & $\begin{array}{l}\text { Gravelly sand-silty sands, silty fine to medium sand, } 30 \% \\
\text { subrounded 1/4-3/4 in gravel, brown (7.5YR5/4). }\end{array}$ \\
\hline G\&M Inc 605 & 74.68 & 76.20 & sand and clay & Silty sands, fine to medium sand, silty. \\
\hline G\&M Inc 605 & 76.20 & 77.72 & sand, clay and gravel & $\begin{array}{l}\text { Sandy gravel-silty gravel, } 1 / 4-3 / 4 \text { in rounded gravel, } 30 \% \\
\text { fine to coarse silty sand, brown }(7.5 \text { YR } 5 / 4) \text {. }\end{array}$ \\
\hline
\end{tabular}


Appendix 1. Compilation of borehole and aquifer data.-Continued

[cm, centimeter; m, meter; in, inch; ft, feet; \%, percent; ppm, parts per million; $\approx$, approximately equal to; $>$, greater than]

\begin{tabular}{|c|c|c|c|c|}
\hline Bore & $\begin{array}{l}\text { Top } \\
(\mathrm{m})\end{array}$ & $\begin{array}{l}\text { Bottom } \\
\text { (m) }\end{array}$ & Simplified lithology & Driller's description \\
\hline G\&M Inc 605 & 77.72 & 80.47 & sand, clay and gravel & $\begin{array}{l}\text { Silty sands-gravelly sand, fine to medium sand silty, } 30 \% \\
\text { subrounded gravel. }\end{array}$ \\
\hline G\&M Inc 605 & 80.47 & 82.30 & sand and gravel & $\begin{array}{l}\text { Gravelly sand, fine to coarse sand, clean } 10 \% 1 / 4 \text { in gravel, } \\
\text { subrounded, brown }(7.5 \mathrm{YR} 4 / 2) \text {. }\end{array}$ \\
\hline G\&M Inc 605 & 82.30 & 85.34 & sand and gravel & $\begin{array}{l}\text { Sandy gravel, medium to coarse sand, } 80 \%, 1 / 4-1 / 2 \text { in } \\
\text { gravel, subrounded, clean brown }(7.5 \mathrm{YR} 4 / 2) .\end{array}$ \\
\hline G\&M Inc 605 & 85.34 & 86.56 & sand, clay and gravel & $\begin{array}{l}\text { Silty gravel, silty } 1 / 4-3 / 4 \text { in gravel, } 20 \% \text { medium to coarse } \\
\text { sand, brown }(7.5 \text { YR } 4 / 2) \text {. }\end{array}$ \\
\hline G\&M Inc 605 & 88.39 & 94.49 & sand and clay & $\begin{array}{l}\text { Silt and very fine sand, 290, brown, slightly clayey silt } \\
\text { (10YR5/3). }\end{array}$ \\
\hline G\&M Inc 605 & 94.49 & 97.54 & sand and gravel & $\begin{array}{l}\text { Silt and very fine sand, } 10 \% 1 / 4-1 / 2 \text { in subangular gravel, } \\
\text { pale brown (10YR6/3). At } 315 \mathrm{ft} \text { no gravel. At } 320 \mathrm{ft} \\
\text { wait for water, no water. }\end{array}$ \\
\hline G\&M Inc 605 & 97.54 & 100.28 & sand, clay and gravel & $\begin{array}{l}\text { Silt and very fine sand-gravelly sand, brown indurated } \\
\text { siltstone to very fine-grained sandstone (10YR5/3). At } \\
325 \mathrm{ft}, 20 \% \text { rounded } 1 / 2-1 \text { in gravel. }\end{array}$ \\
\hline G\&M Inc 605 & 102.11 & 114.30 & sand and clay & $\begin{array}{l}\text { Silty sands, very cemented siltstone to very fine-grained } \\
\text { sandstone, } 10 \% \text { coarse sand }(10 \mathrm{YR} 6 / 2) \text { light brown- } \\
\text { ish gray. At } 340 \mathrm{ft} \text { water level } \approx 309.42 \mathrm{ft}, 2 \mathrm{hr} \text {, rising } \\
(-305.54) \text {. At } 350 \mathrm{ft} \text { water level } \approx 313.72 \mathrm{ft},(1 \mathrm{hr}) \text {, rising } \\
(-298.20) \text {. At } 360 \mathrm{ft} \text { water level } \approx 314.25 \mathrm{ft}(4 \mathrm{hr}) \text {, ris- } \\
\text { ing }(-310.28) \text {. At } 361 \mathrm{ft} \text { silty sands, slightly indurated } \\
\text { silt to very fine sand, } 20 \% 1 / 4-1 \text { in gravel subangu- } \\
\text { lar }(10 \mathrm{YR} 6 / 2) \text {. Light brownish gray and light gray } \\
(10 \mathrm{YR} 7 / 2) \text {. At } 370 \mathrm{ft} \text { water level } \approx 338.05 \mathrm{ft}(1 \mathrm{hr}) \text {, rising } \\
(-317.61) .\end{array}$ \\
\hline
\end{tabular}


Appendix 1. Compilation of borehole and aquifer data.-Continued

[cm, centimeter; $\mathrm{m}$, meter; in, inch; $\mathrm{ft}$, feet; \%, percent; ppm, parts per million; $\approx$, approximately equal to; >, greater than]

\begin{tabular}{|c|c|c|c|c|}
\hline Bore & $\begin{array}{l}\text { Top } \\
\text { (m) }\end{array}$ & $\begin{array}{c}\text { Bottom } \\
\text { (m) }\end{array}$ & Simplified lithology & Driller's description \\
\hline G\&M Inc 605 & 114.30 & 127.10 & $\begin{array}{l}\text { sand, clay and trace } \\
\text { gravel }\end{array}$ & $\begin{array}{l}\text { Silt and very fine sand, Grayish soft clayey silt, slightly } \\
\text { sticky, smooth light brownish gray }(10 \mathrm{YR} 6 / 2) \text {. At } 380 \mathrm{ft} \\
\text { water level } \approx 289.75 \mathrm{ft}(15 \mathrm{hrs})(-279.33) \text {. At } 390 \mathrm{ft} \text { water } \\
\text { level } \geq 300 \mathrm{ft}(1 \mathrm{hr}) \text {, rising, silt and very fine sand, in- } \\
\text { durated silt, no clay, brown }(10 \mathrm{YR} 5 / 3) \text {. At } 396 \mathrm{ft} \text { clayey } \\
\text { sand, brown clayey silt, indurated. At } 400 \mathrm{ft} \text { water } \\
\text { level } \approx 382 \mathrm{ft}(1.5 \mathrm{hr})(-366.16) \text {. At } 401 \mathrm{ft} \text { clayey sand, } \\
\text { indurated clayey silt, brown }(10 \mathrm{YR} 5 / 3), 5 \% 1 / 4-1 / 2 \mathrm{in} \\
\text { subangular gravel. At } 410 \mathrm{ft} \text { water level } \approx 337.73 \mathrm{ft} \text { (after } \\
1 \mathrm{hr}) \text { (no gravel) }(-332.13) \text {. At } 412 \mathrm{ft} \text { clayey sand, silt, } \\
\text { slightly indurated, brown }(10 \mathrm{YR} 5 / 3) \text {. At } 415 \mathrm{ft} 10 \% \\
\text { medium to coarse sand. }\end{array}$ \\
\hline
\end{tabular}

G\&M Inc 605

G\&M Inc 605

127.71

129.5

sand

G\&M Inc 605

129.54

132.59

sand, clay and gravel

and, clay and trace gravel

Gravelly sand, $417.5 \mathrm{ft}$ slight rig chatter making water.

At $420 \mathrm{ft}$ silty sands, $60 \%$ medium to coarse sand, brown (10YR5/3), 40\% light brownish gray (10YR6/2), slightly indurated. At $420 \mathrm{ft}$ water level $\approx 317.5 \mathrm{ft}$ (after $17 \mathrm{hrs}$ ) $(-313.5)$. At $424 \mathrm{ft}$ heavy rig chatter.

Sandy gravel, $40 \%$ angular gravel chips $30 \%$ medium to coarse sand, light brown silt, slightly indurated. At $430 \mathrm{ft}$, gravel (1/4-1/2 in cobbles (?). Angular chips, $20 \%$ light brown, slightly indurated silt.

G\&M Inc 605

132.59

134.11

sand, clay and gravel

Silty gravel, cobble chips, angular medium to coarse sand sized grains (heavy rig chatter) $10 \%$ silt, indurated. At $440 \mathrm{ft}$ water level $-319.64 \mathrm{ft}$ (16 hrs), total depth $440 \mathrm{ft}$.

GSI 304

0.00

0.91

sand, clay and gravel

Fill, sandy gravel with silt, brown.

GSI 304

0.91

3.35

sand, clay and gravel

GSI 304

3.35

4.11

sand, clay and gravel

GSI 304

4.11

4.42

sand and gravel

4.42

4.88

sand, clay and gravel

6.10

sand, clay and gravel

6.71

sand, clay and gravel

sand, clay and gravel
Sandy gravel with silt, brown with cobbles partially cemented.

Sand with gravel, silt, light brown.

Cemented sandy gravel, light brown.

Gravelly sand with silt, brown.

Sand with silt, gravel, brown.

Sandy gravel with silt, brown.

Sand with gravel, silt, brown. With cobbles. 
Appendix 1. Compilation of borehole and aquifer data.-Continued

[cm, centimeter; m, meter; in, inch; ft, feet; \%, percent; ppm, parts per million; $\approx$, approximately equal to; $>$, greater than]

\begin{tabular}{|c|c|c|c|c|}
\hline Bore & $\begin{array}{l}\text { Top } \\
(\mathrm{m})\end{array}$ & $\begin{array}{l}\text { Bottom } \\
(\mathrm{m})\end{array}$ & Simplified lithology & Driller's description \\
\hline GSI 304 & 8.23 & 11.28 & sand, clay and gravel & Silty sand with gravel, brown. \\
\hline GSI 304 & 11.28 & 15.24 & sand, clay and gravel & Sandy gravel with silt, brown. \\
\hline GSI 304 & 16.15 & 16.76 & sand, clay and gravel & Sand with gravel, silt, light brown. \\
\hline GSI 304 & 16.76 & 17.68 & sand, clay and gravel & Gravelly sand with silt, light brown. \\
\hline GSI 304 & 23.77 & 24.69 & sand, clay and gravel & Gravelly silt with sand, clay, light brown. \\
\hline GSI 304 & 24.69 & 28.35 & sand, clay and gravel & $\begin{array}{l}\text { Silty gravel with sand, occasional. Cobbles, light brown. } \\
\text { Cobble zone 89-90. }\end{array}$ \\
\hline GSI 304 & 28.35 & 30.48 & sand, clay and gravel & Gravel, s/clay, silt, light brown. \\
\hline GSI 304 & 30.48 & 33.83 & sand, clay and gravel & Gravel with clay, silt with small clay layers, light brown. \\
\hline GSI 304 & 38.10 & 40.23 & sand, clay and gravel & Gravelly sand with silt, light brown. With cobbles. \\
\hline GSI 304 & 40.23 & 44.81 & sand, clay and gravel & $\begin{array}{l}\text { Silty gravel with gravel, occasional. Cobbles, brown/gray. } \\
\text { Cobbles zone } 142-143 \text {. }\end{array}$ \\
\hline GSI 304 & 44.81 & 45.11 & clay, sand and gravel & clay gravel with cobbles, light brown. \\
\hline GSI 304 & 45.11 & 45.72 & sand, clay and gravel & Silty gravel with occasional. Cobbles, light brown. \\
\hline GSI 304 & 45.72 & 46.33 & sand, clay and gravel & Silty gravel with occasional. Cobbles, light brown. \\
\hline GSI 304 & 46.33 & 49.38 & clay, sand and gravel & $\begin{array}{l}\text { Clayey gravel with sand, light brown. Cobble zone } \\
\text { 156-157. Cobble zone 159-160. }\end{array}$ \\
\hline
\end{tabular}


Appendix 1. Compilation of borehole and aquifer data.-Continued

[cm, centimeter; $\mathrm{m}$, meter; in, inch; ft, feet; \%, percent; ppm, parts per million; $\approx$, approximately equal to; $>$, greater than]

\begin{tabular}{|c|c|c|c|c|}
\hline Bore & $\begin{array}{l}\text { Top } \\
\text { (m) }\end{array}$ & $\begin{array}{l}\text { Bottom } \\
\text { (m) }\end{array}$ & Simplified lithology & Driller's description \\
\hline GSI 304 & 49.38 & 51.21 & sand, clay and gravel & $\begin{array}{l}\text { Silty sand with gravel, brown, clay, light brown. With } \\
\text { cobbles. }\end{array}$ \\
\hline GSI 304 & 51.21 & 60.96 & clay, sand and gravel & $\begin{array}{l}\text { Clayey gravel with sand, silt, cobbles, light brown. Cobble } \\
\text { zone } 173-174 \text {, cobble zone } 176-177 \text {, cobble zone } \\
\text { 181-182, cobble zone } 184-187 \text {, cobble zone } 194-197 \text {. }\end{array}$ \\
\hline GSI 304 & 60.96 & 65.84 & clay, sand and gravel & $\begin{array}{l}\text { Clayey gravel with sand, silt, cobbles, light brown. Cobble } \\
\text { zone 201-202, cobble zone 204-209. }\end{array}$ \\
\hline GSI 304 & 65.84 & 66.75 & clay, sand and gravel & Clayey sand with gravel, dark brown with cobbles. \\
\hline GSI 304 & 70.10 & 73.15 & clay, sand and gravel & $\begin{array}{l}\text { Clayey sand with gravel, silt, dark brown. Cobble zone } \\
\text { 236-238. }\end{array}$ \\
\hline GSI 304 & 73.15 & 75.59 & clay, sand and gravel & $\begin{array}{l}\text { Sandy clay with gravel, cobbles, dark brown. Cobble zone } \\
245-248 \text {. }\end{array}$ \\
\hline GSI 304 & 75.59 & 76.20 & sand, clay and gravel & Silty sand with gravel, clay, dark brown. \\
\hline GSI 304 & 76.20 & 80.16 & sand, clay and gravel & Silty sand with gravel, clay, dark brown. \\
\hline GSI 304 & 88.39 & 90.68 & clay, sand and gravel & Silty clay with gravel, light brown. \\
\hline GSI 304 & 90.68 & 91.44 & clay, sand and gravel & Sandy clay with gravel, light brown white in color. \\
\hline GSI 304 & 91.44 & 92.66 & clay, sand and gravel & Sandy clay with gravel, white. \\
\hline GSI 304 & 92.66 & 93.57 & sand, clay and gravel & Sandy clay, light brown and light green clay. \\
\hline GSI 304 & 93.57 & 95.10 & clay, sand and gravel & Sandy silt with gravel, clay, light green light brown. \\
\hline GSI 304 & 95.10 & 96.62 & sand, clay and gravel & Silty sand with gravel, light brown. \\
\hline GSI 304 & 96.62 & 97.38 & clay, sand and gravel & Silty clay with gravel, light green. \\
\hline
\end{tabular}


Appendix 1. Compilation of borehole and aquifer data.-Continued

[cm, centimeter; m, meter; in, inch; ft, feet; \%, percent; ppm, parts per million; $\approx$, approximately equal to; $>$, greater than]

\begin{tabular}{|c|c|c|c|c|}
\hline Bore & $\begin{array}{l}\text { Top } \\
(\mathrm{m})\end{array}$ & $\begin{array}{l}\text { Bottom } \\
\text { (m) }\end{array}$ & Simplified lithology & Driller's description \\
\hline GSI 304 & 97.38 & 97.84 & sand, clay and gravel & Silty sand with gravel, light green. \\
\hline GSI 304 & 97.84 & 98.76 & clay, sand and gravel & Sandy silt with gravel, light green. \\
\hline GSI 304 & 99.67 & 100.58 & sand, clay and gravel & Clayey silt with gravel, sand, light green. \\
\hline GSI 304 & 100.58 & 102.11 & clay, sand and gravel & Sandy silt with gravel, clay, light green light brown. \\
\hline GSI 304 & 103.33 & 106.68 & sand, clay and gravel & $\begin{array}{l}\text { Clayey silt with gravel, sand, light green light brown with } \\
\text { silty sand and silty clay layers. }\end{array}$ \\
\hline GSI 304 & 106.68 & 107.14 & sand, clay and gravel & Clayey silt with gravel, silt, light, brown and light green. \\
\hline GSI 304 & 107.14 & 108.51 & sand, clay and gravel & $\begin{array}{l}\text { Silty sand with gravel and small clayey silt layers, white to } \\
\text { light brown. }\end{array}$ \\
\hline GSI 304 & 108.51 & 109.42 & clay, sand and gravel & Clayey sand with gravel white. \\
\hline GSI 304 & 113.08 & 114.60 & sand, clay and gravel & clay silt with gravel, light brown and light green. \\
\hline GSI 304 & 114.60 & 115.82 & clay, sand and gravel & Sandy silt with gravel, light brown/light green with clay. \\
\hline GSI 304 & 115.82 & 121.92 & clay, sand and gravel & Bottom at $380 \mathrm{ft}$. \\
\hline GSI 305 & 0.00 & 2.74 & sand, clay and gravel & $\begin{array}{l}\text { Sandy gravel with silt, light brown with cobbles partially } \\
\text { cemented with clay. }\end{array}$ \\
\hline GSI 305 & 2.74 & 3.66 & sand, clay and gravel & Gravel sand with silt, brown. \\
\hline GSI 305 & 3.66 & 3.96 & sand and gravel & Cemented sand and gravel, light brown. \\
\hline GSI 305 & 3.96 & 5.18 & sand, clay and gravel & Sand gravel with silt, brown. \\
\hline
\end{tabular}


Appendix 1. Compilation of borehole and aquifer data.-Continued

[cm, centimeter; $\mathrm{m}$, meter; in, inch; ft, feet; \%, percent; ppm, parts per million; $\approx$, approximately equal to; $>$, greater than]

\begin{tabular}{|c|c|c|c|c|}
\hline Bore & $\begin{array}{l}\text { Top } \\
\text { (m) }\end{array}$ & $\begin{array}{l}\text { Bottom } \\
\text { (m) }\end{array}$ & Simplified lithology & Driller's description \\
\hline GSI 305 & 5.18 & 7.01 & sand, clay and gravel & Sandy gravel with silt, brown. \\
\hline GSI 305 & 7.01 & 9.14 & sand, clay and gravel & Sand gravel with silt, brown with cobbles. \\
\hline GSI 305 & 10.97 & 15.24 & sand, clay and gravel & Sandy gravel with silt, cobbles, brown. \\
\hline GSI 305 & 15.24 & 18.90 & sand, clay and gravel & Sandy gravel with silt, cobbles, brown. \\
\hline GSI 305 & 19.81 & 28.04 & sand, clay and gravel & $\begin{array}{l}\text { Sandy gravel with silt, cobbles, brown. Large gravel } \\
\quad 67-90 \mathrm{~cm} .\end{array}$ \\
\hline GSI 305 & 28.04 & 28.35 & clay, sand and gravel & Sandy clay with gravel, light brown. \\
\hline GSI 305 & 28.35 & 28.65 & sand, clay and gravel & clay gravel with silt, light brown. \\
\hline GSI 305 & 28.65 & 29.87 & sand, clay and gravel & Silty gravel with sand, clay, cobbles, light brown. \\
\hline GSI 305 & 31.70 & 44.81 & clay, sand and gravel & $\begin{array}{l}\text { Clayey gravel with silt, sand, light brown. Cobble zone } \\
105-109 \mathrm{ft}, 117-121 \mathrm{ft}, 124-126 \mathrm{ft}, 134-139 \mathrm{ft}, \\
133-134 \mathrm{ft} \text {. }\end{array}$ \\
\hline GSI 305 & 44.81 & 45.42 & clay, sand and gravel & Clayey sand with gravel, light brown. \\
\hline GSI 305 & 45.42 & 45.72 & clay, sand and gravel & Clayey gravel, light brown. \\
\hline GSI 305 & 45.72 & 70.10 & clay, sand and gravel & $\begin{array}{l}\text { Clayey gravel with sand, silt, cobbles, light brown. Cobble } \\
\text { zone } 150-164 \mathrm{ft}, 168-169 \mathrm{ft}, 173-175 \mathrm{ft}, 184-189 \mathrm{ft}, \\
196-200 \mathrm{ft} \text {. Clayey gravel with sand, silt, cobbles, light } \\
\text { brown. Cobble zone } 202-204 \mathrm{ft}, 214-219 \mathrm{ft}, 221-222 \mathrm{ft} \text {, } \\
226-232 \mathrm{ft}\end{array}$ \\
\hline
\end{tabular}


Appendix 1. Compilation of borehole and aquifer data.-Continued

[cm, centimeter; m, meter; in, inch; ft, feet; \%, percent; ppm, parts per million; $\approx$, approximately equal to; $>$, greater than]

\begin{tabular}{|c|c|c|c|c|}
\hline Bore & $\begin{array}{l}\text { Top } \\
(\mathrm{m})\end{array}$ & $\begin{array}{l}\text { Bottom } \\
\text { (m) }\end{array}$ & Simplified lithology & Driller's description \\
\hline GSI 305 & 71.93 & 76.20 & clay, sand and gravel & Clayey gravel, sand, silt, cobbles, light brown. \\
\hline GSI 305 & 76.20 & 79.25 & clay, sand and gravel & $\begin{array}{l}\text { Clayey gravel with sand, silt, cobbles, light brown. Cobble } \\
\text { zone } 255-257 .\end{array}$ \\
\hline GSI 305 & 84.12 & 84.73 & sand and clay & Clayey sand with silt, light brown. \\
\hline GSI 305 & 87.17 & 91.44 & sand and gravel & $\begin{array}{l}\text { Sand and clay, light brown and light green, alternating } \\
\text { seams. }\end{array}$ \\
\hline GSI 305 & 91.44 & 91.74 & sand and gravel & Sand and clay, light brown, light green. \\
\hline GSI 305 & 91.74 & 92.81 & clay and sand & Sand clay, light brown and light green. \\
\hline GSI 305 & 92.81 & 94.34 & clay and sand & Sandy clay, light brown and light green. \\
\hline GSI 305 & 103.63 & 105.16 & sand and clay & Clayey sand with silt, light brown, light green. \\
\hline GSI 305 & 105.16 & 106.68 & sand and clay & Silty sand with clay, white light brown. \\
\hline GSI 305 & 106.68 & 110.34 & sand, clay and gravel & $\begin{array}{l}\text { Silty sand with gravel, clay, white light brown with brown } \\
\text { silty sand layers. }\end{array}$ \\
\hline GSI 305 & 110.34 & 112.47 & sand and clay & Sandy clay with silt, light green/ light brown. \\
\hline GSI 305 & 112.47 & 114.00 & sand and clay & Clayey sand with silt, white light brown. \\
\hline GSI 305 & 114.00 & 115.82 & clay and sand & Sandy clay, light green, light brown. \\
\hline GSI 305 & 115.82 & 121.92 & clay and sand & Bottom at $380 \mathrm{ft}$. \\
\hline
\end{tabular}


Appendix 1. Compilation of borehole and aquifer data.-Continued

[cm, centimeter; $\mathrm{m}$, meter; in, inch; $\mathrm{ft}$, feet; \%, percent; ppm, parts per million; $\approx$, approximately equal to; >, greater than]

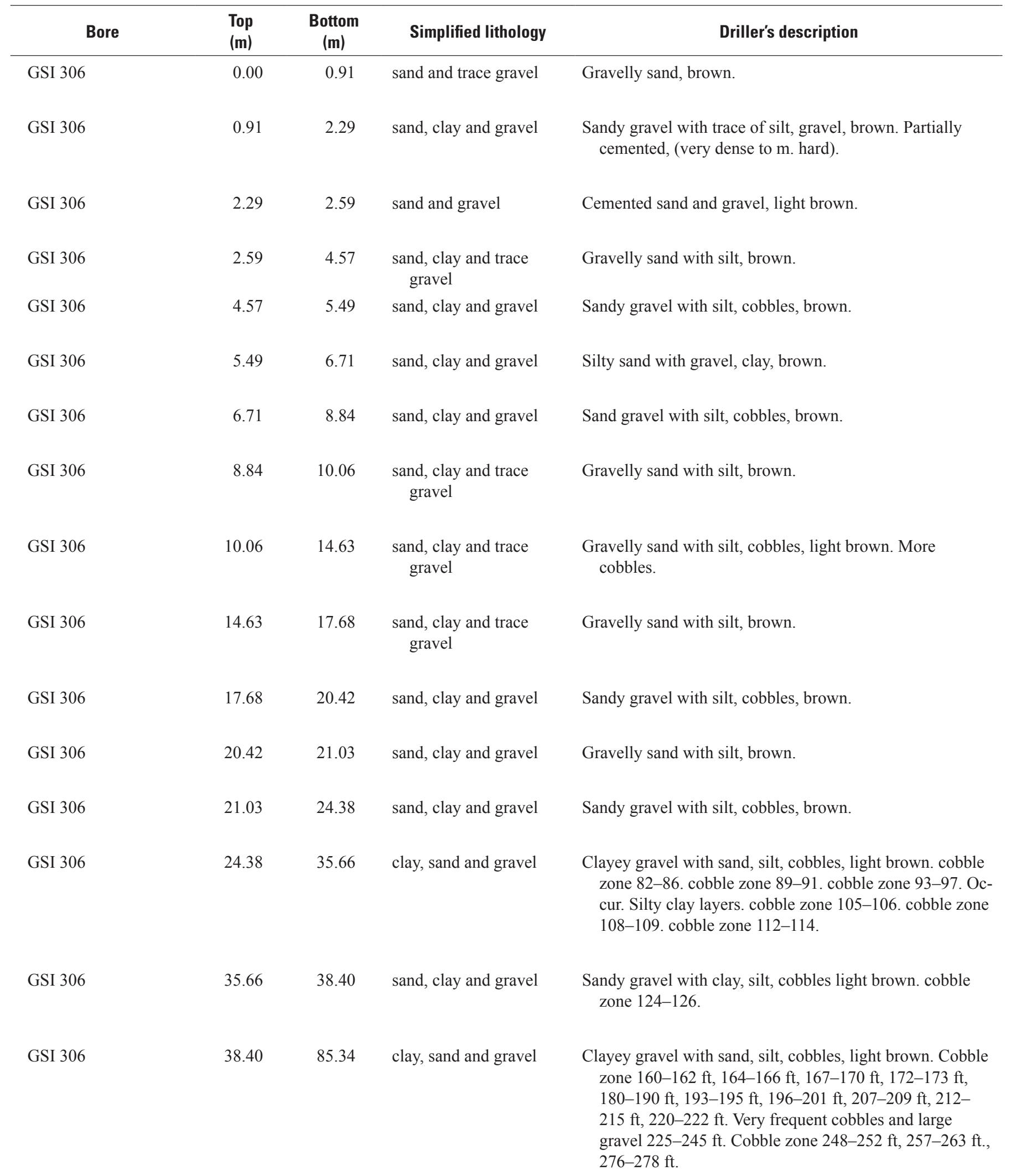


Appendix 1. Compilation of borehole and aquifer data.-Continued

[cm, centimeter; m, meter; in, inch; ft, feet; \%, percent; ppm, parts per million; $\approx$, approximately equal to; $>$, greater than]

\begin{tabular}{|c|c|c|c|c|}
\hline Bore & $\begin{array}{l}\text { Top } \\
\text { (m) }\end{array}$ & $\begin{array}{l}\text { Bottom } \\
(\mathrm{m})\end{array}$ & Simplified lithology & Driller's description \\
\hline GSI 306 & 85.34 & 86.26 & sand and clay & Clayey sand with trace gravel. light brown. \\
\hline GSI 306 & 86.26 & 88.39 & clay, sand and gravel & Sandy clay with gravel, light brown and light green. \\
\hline GSI 306 & 91.44 & 92.96 & clay, sand and gravel & Sandy clay with sand, gravel, light green light brown. \\
\hline GSI 306 & 92.96 & 93.57 & clay and sand & Sand clay, light green with white silty clay layers. \\
\hline GSI 306 & 100.58 & 105.77 & sand, clay and gravel & Silty sand with gravel, light green. White silty clay layers. \\
\hline GSI 306 & 105.77 & 106.07 & clay and sand & Silty clay with sand, white. \\
\hline GSI 306 & 106.07 & 106.68 & clay and sand & Sandy silt with clay, light brown and light green. \\
\hline GSI 306 & 106.68 & 107.29 & clay and sand & Sandy silt with clay, white light green. \\
\hline GSI 306 & 107.29 & 107.75 & clay and sand & Silty clay with sand, white. \\
\hline GSI 306 & 115.82 & 121.92 & clay and sand & Bottom at $380 \mathrm{ft}$. \\
\hline IT Corp 500 & 0.00 & 2.13 & sand & Pale brown (10YR6/3) sand, dry, well graded, subangular. \\
\hline IT Corp 500 & 2.13 & 5.18 & sand, clay and gravel & $\begin{array}{l}\text { Yellowish brown (10YR5/4) Gravel with sand, moist, well } \\
\text { graded, subrounded, trace clay. Contains rhyolite frag- } \\
\text { ments, quartz, feldspar, chert, and minor mafic minerals. }\end{array}$ \\
\hline IT Corp 500 & 5.18 & 7.01 & sand and gravel & $\begin{array}{l}\text { Very pale brown }(10 \text { YR } 7 / 3) \text { sand, moist, well graded, } \\
\text { subangular. Contains rhyolite fragments and minor mafic } \\
\text { minerals. }\end{array}$ \\
\hline IT Corp 500 & 7.01 & 8.53 & Gravel & $\begin{array}{l}\text { Very pale brown (10YR7/3) gravel, moist, well graded, } \\
\text { subangular. Contains rhyodacite and rhyolite fragments. }\end{array}$ \\
\hline
\end{tabular}


Appendix 1. Compilation of borehole and aquifer data.-Continued

[cm, centimeter; $\mathrm{m}$, meter; in, inch; $\mathrm{ft}$, feet; $\%$, percent; ppm, parts per million; $\approx$, approximately equal to; >, greater than]

\begin{tabular}{|c|c|c|c|c|}
\hline Bore & $\begin{array}{l}\text { Top } \\
(\mathrm{m})\end{array}$ & $\begin{array}{l}\text { Bottom } \\
\text { (m) }\end{array}$ & Simplified lithology & Driller's description \\
\hline IT Corp 500 & 8.53 & 10.06 & sand and gravel & $\begin{array}{l}\text { Very pale brown }(10 \mathrm{YR} 7 / 3) \text { sand with gravel, dry, well } \\
\text { graded sand, subangular, gravel to } 1 / 4 \text { in. Predominantly } \\
\text { mineralogy is rhyolite and } 5 \text { to } 10 \% \text { quartz. }\end{array}$ \\
\hline IT Corp 500 & 10.06 & 11.58 & Gravel & $\begin{array}{l}\text { Very pale brown (10YR8/4) gravel, dry, well graded, sub- } \\
\text { angular, gravel less than } 1 / 2 \text { in. }\end{array}$ \\
\hline IT Corp 500 & 11.58 & 13.11 & nonwelded tuff & Pink (5YR7/4) sand, dry, well graded, subangular. \\
\hline IT Corp 500 & 13.11 & 14.63 & nonwelded tuff & $\begin{array}{l}\text { Pink (5YR7/4) gravel, dry, well graded, subrounded, gravel } \\
\quad<1 \text { in. Predominant mineralogy is rhyolite and dacite. }\end{array}$ \\
\hline IT Corp 500 & 16.15 & 18.29 & nonwelded tuff & Pink (5YR7/4) sandy gravel, dry, well graded. \\
\hline IT Corp 500 & 18.29 & 19.20 & nonwelded tuff & $\begin{array}{l}\text { Pink (7.5YR7/3) to black }(7.5 \mathrm{YR} 2 / 0) \text { gravel with sand, } \\
\text { dry, coarse-grained sand, gravel to } 3 / 4 \mathrm{in} \text {, well graded, } \\
\text { angular. Grains, consist of dacite and rhyolite. }\end{array}$ \\
\hline IT Corp 500 & 19.20 & 22.25 & sand and gravel & $\begin{array}{l}\text { Light brown (7.5YR6/4) sand with gravel, dry, gravel to } \\
1 / 4 \text { in, well graded, subangular. }\end{array}$ \\
\hline IT Corp 500 & 27.43 & 28.35 & sand and trace gravel & $\begin{array}{l}\text { Gravelly sand. Grains consist of rhyolite, feldspar, quartz, } \\
\text { minor mafic minerals, and chert. }\end{array}$ \\
\hline IT Corp 500 & 28.35 & 30.48 & sand and gravel & Gravel with sand, subangular, gravel $>1$ in diameter. \\
\hline IT Corp 500 & 30.48 & 32.00 & sand and gravel & $\begin{array}{l}\text { Sandy gravel, subangular, gravel to } 1 / 2 \mathrm{in} \text {. Grains consist } \\
\text { of dacite and rhyolite. }\end{array}$ \\
\hline IT Corp 500 & 32.00 & 35.05 & sand and gravel & $\begin{array}{l}\text { Gravel, dry, subangular, gravel }>3 / 4 \text { in, same sand. Grains } \\
\text { consist of rhyolite, tuff, and possibly basalt. }\end{array}$ \\
\hline IT Corp 500 & 35.05 & 36.58 & sand and gravel & $\begin{array}{l}\text { Sandy gravel, gravel }>1 / 2 \text { in. Contains rhyolite, feldspar, } \\
\text { and quartz. }\end{array}$ \\
\hline
\end{tabular}


Appendix 1. Compilation of borehole and aquifer data.-Continued

[cm, centimeter; m, meter; in, inch; ft, feet; \%, percent; ppm, parts per million; $\approx$, approximately equal to; $>$, greater than]

\begin{tabular}{|c|c|c|c|c|}
\hline Bore & $\begin{array}{l}\text { Top } \\
\text { (m) }\end{array}$ & $\begin{array}{l}\text { Bottom } \\
\text { (m) }\end{array}$ & Simplified lithology & Driller's description \\
\hline IT Corp 500 & 36.58 & 37.49 & sand and gravel & Gravel with sand, dry, subangular, gravel less than $1 / 2$ in. \\
\hline IT Corp 500 & 37.49 & 39.62 & nonwelded tuff & $\begin{array}{l}\text { Pink }(7.5 \mathrm{YR} 7 / 3) \text { sand with gravel, dry, subangular, gravel } \\
\text { to } 1 / 4 \text { in diameter. }\end{array}$ \\
\hline IT Corp 500 & 40.54 & 43.59 & sand and gravel & $\begin{array}{l}\text { Light brown (7.5YR6/4) sandy gravel, dry, subangular, } \\
\text { gravel }>1 \text { in diameter. Grains consist of rhyolite, dacite, } \\
\text { and occasional quartzite and biotite schist. }\end{array}$ \\
\hline IT Corp 500 & 45.11 & 47.24 & Gravel & $\begin{array}{l}\text { Hard drilling } 149 \text { to } 151 \mathrm{ft} \text {. Pink ( } 7.5 \mathrm{YR} 7 / 3) \text { gravel, well } \\
\text { graded, gravel }>3 / 4 \text { in diameter. Grains predominantly } \\
\text { rhyolite, dacite, and occasional quartzite. }\end{array}$ \\
\hline IT Corp 500 & 47.24 & 48.77 & sand and gravel & $\begin{array}{l}\text { Brown }(7.5 \mathrm{YR} 5 / 3) \text { gravel with sand, dry, well graded, } \\
\text { gravel to } 1 / 2 \text { in diameter. Contains chalcedony filled } \\
\text { rhyolite, quartzite, and occasional basalt fragments. }\end{array}$ \\
\hline IT Corp 500 & 53.34 & 60.35 & sand, clay and gravel & $\begin{array}{l}\text { Brown ( } 7.5 \text { YR5/4) gravelly sand with silt and clay, dry, } \\
\text { well graded, subangular, gravel to } 1 / 2 \text { in diameter. } \\
\text { Grains consist of predominantly of rhyolite, and oc- } \\
\text { casional quartzite, quartz, biotite-rich fragments, and } \\
\text { basalt fragments. }\end{array}$ \\
\hline IT Corp 500 & 60.35 & 61.87 & nonwelded tuff & $\begin{array}{l}\text { Pink ( } 7.5 \text { YR7/4) gravelly sand, dry, well graded, subangu- } \\
\text { lar, gravel to } 1 / 2 \text { in diameter. }\end{array}$ \\
\hline IT Corp 500 & 61.87 & 64.01 & nonwelded tuff & $\begin{array}{l}\text { Pink (7.5YR7/4) gravelly sand, dry, well graded, subangu- } \\
\text { lar, gravel to } 1 / 4 \text { in diameter. Grains consists of rhyolite } \\
\text { with quartz and feldspar phenocrysts. }\end{array}$ \\
\hline IT Corp 500 & 64.01 & 64.92 & sand, clay and gravel & $\begin{array}{l}\text { Brown (7.5YR5/4) gravelly sand, moist, subrounded, } \\
\text { gravel to } 1 / 4 \text { in diameter, trace silts and clays. }\end{array}$ \\
\hline
\end{tabular}


Appendix 1. Compilation of borehole and aquifer data.-Continued

[cm, centimeter; $\mathrm{m}$, meter; in, inch; ft, feet; \%, percent; ppm, parts per million; $\approx$, approximately equal to; >, greater than]

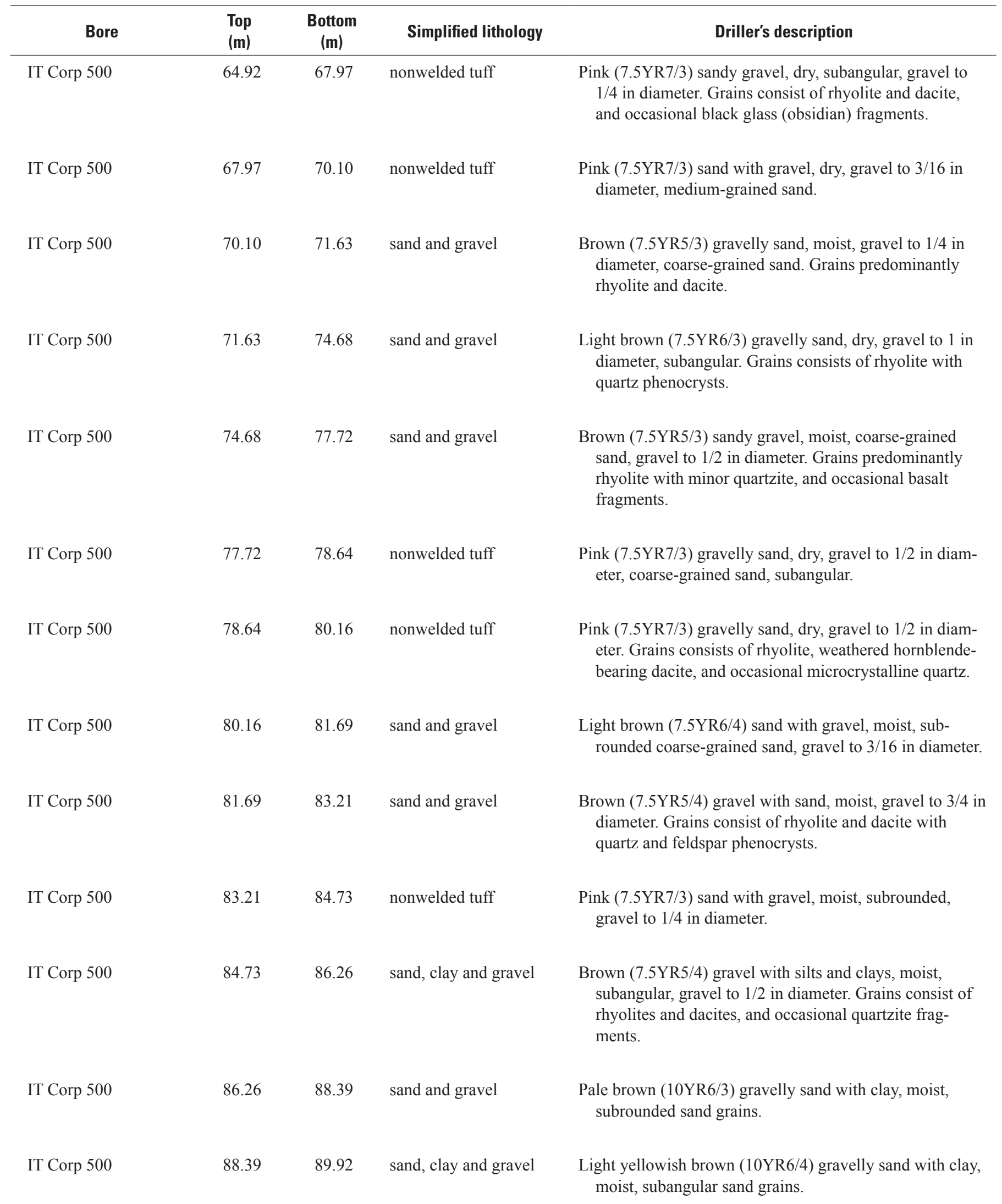


Appendix 1. Compilation of borehole and aquifer data.-Continued

[cm, centimeter; $\mathrm{m}$, meter; in, inch; ft, feet; \%, percent; ppm, parts per million; $\approx$, approximately equal to; >, greater than]

\begin{tabular}{|c|c|c|c|c|}
\hline Bore & $\begin{array}{l}\text { Top } \\
(\mathrm{m})\end{array}$ & $\begin{array}{l}\text { Bottom } \\
(\mathrm{m})\end{array}$ & Simplified lithology & Driller's description \\
\hline IT Corp 500 & 89.92 & 90.83 & sand & $\begin{array}{l}\text { Light gray (10YR7/2) sand, dry, subrounded coarse- } \\
\text { grained sand. }\end{array}$ \\
\hline IT Corp 500 & 90.83 & 90.98 & sand and gravel & $\begin{array}{l}\text { Very pale brown }(10 \mathrm{YR} 7 / 3) \text { gravelly sand, moist, gravel } \\
\text { to } 3 / 16 \text { in diameter, coarse-grained sand, subrounded. } \\
\text { Grains consist predominantly of rhyolite and dacite. } \\
\text { Total depth } 298.56 \mathrm{ft} \text {. }\end{array}$ \\
\hline IT Corp 501 & 0.00 & 4.57 & sand and gravel & $\begin{array}{l}\text { Dark brown }(7.5 \mathrm{YR} 4 / 4) \text { gravelly sand dry, subrounded } \\
\text { gravel }>3 / 4 \text { in diameter. At } 10 \mathrm{ft} \text { color change to pale } \\
\text { brown }(10 \mathrm{YR} 6 / 3) \text { gravel size }>11 / 2 \text { in diameter. }\end{array}$ \\
\hline IT Corp 501 & 15.24 & 16.76 & sand and gravel & $\begin{array}{l}\text { Dark yellowish brown (10YR4/4) sandy gravel, dry suban- } \\
\text { gular to rounded, gravel to } 1 \text { in diameter, well graded. }\end{array}$ \\
\hline IT Corp 501 & 16.76 & 21.34 & sand and gravel & $\begin{array}{l}\text { Yellowish brown }(10 \mathrm{YR} 5 / 4) \text { gravelly sand, dry, subround- } \\
\text { ed to rounded, well graded, gravel to } 3 / 4 \text { in diameter. }\end{array}$ \\
\hline IT Corp 501 & 21.34 & 24.38 & sand and gravel & $\begin{array}{l}\text { Yellowish brown }(10 \mathrm{YR} 5 / 4) \text { sand with gravel, dry, gravel } \\
\text { to } 1 / 2 \text { in diameter. }\end{array}$ \\
\hline IT Corp 501 & 27.43 & 31.82 & sand and gravel & $\begin{array}{l}\text { Yellowish brown }(10 \mathrm{YR} 5 / 4) \text { sandy gravel, dry, subangular } \\
\text { to subrounded, gravel to } 1 \text { in diameter. At } 100 \mathrm{ft} \text { slight } \\
\text { increase in sand percentage. Total depth } 104.4 \mathrm{ft} \text {. }\end{array}$ \\
\hline
\end{tabular}

Law Eng 101

Law Eng 101

Law Eng 101

2.44

11.58

sand, clay and gravel

Law Eng 101

clay, sand and gravel

2.44 sand, clay and gravel
Silty gravel, Gray-brown silty sandy fine to coarse gravel and cobbles, noncemented.

Silty sands, very dense gray-tan silty sand with fine to coarse gravel and occasional cobbles, noncemented with occasional partially cemented layers.

Silty sands/silty gravel, very dense gray-tan silty sand and gravel, partially cemented. 
Appendix 1. Compilation of borehole and aquifer data.-Continued

[cm, centimeter; $\mathrm{m}$, meter; in, inch; ft, feet; \%, percent; ppm, parts per million; $\approx$, approximately equal to; >, greater than]

\begin{tabular}{rcccc}
\hline Bore & $\begin{array}{c}\text { Top } \\
(\mathbf{m})\end{array}$ & $\begin{array}{c}\text { Bottom } \\
(\mathbf{m})\end{array}$ & Simplified lithology & Driller's description \\
\hline Law Eng 101 & 14.33 & 15.85 & $\begin{array}{c}\text { sand, clay and trace } \\
\text { gravel }\end{array}$ & $\begin{array}{c}\text { Very dense tan silty sand and scattered gravel, } \\
\text { noncemented. }\end{array}$ \\
Law Eng 101 & 15.85 & 23.77 & sand, clay and gravel & $\begin{array}{c}\text { Silty sands/silty gravel, very dense gray-tan silty sand } \\
\text { and gravel, partially cemented with occasional well } \\
\text { cemented layers. }\end{array}$ \\
\hline
\end{tabular}

Law Eng 101

Law Eng 101

Law Eng 101

Law Eng 102

Law Eng 102

Law Eng 102

Law Eng 102

Law Eng 102

Law Eng 102

Law Eng 102

sand, clay and gravel

Law Eng 102

24.38

28.96

sand, clay and gravel

Law Eng 103
0.00
30.48 sand, clay and gravel

39.62 sand, clay and gravel

42.67 sand, clay and gravel

$0.91 \quad$ clay and sand

1.83 sand and gravel

5.49 sand, clay and gravel

12.19 sand, clay and gravel

14.33 sand, clay and gravel

18.29 sand, clay and gravel
Silty sands/silty gravel, very dense
with gravel, partially cemented.

Silty gravel/Sandy clay gravel, very dense red-brown silty sandy gravel with cobbles, partially cemented by clayey matrix.

Silty sands/silty gravel, very dense gray-tan (slight brown) silty sand and gravel with scattered cobbles, noncemented. Boring terminated at $95 \mathrm{ft}$.

Silty sands, light gray-brown very fine sand and silt, noncemented. 
Appendix 1. Compilation of borehole and aquifer data.-Continued

[cm, centimeter; $\mathrm{m}$, meter; in, inch; ft, feet; \%, percent; ppm, parts per million; $\approx$, approximately equal to; >, greater than]

\begin{tabular}{|c|c|c|c|c|}
\hline Bore & $\begin{array}{l}\text { Top } \\
(\mathrm{m})\end{array}$ & $\begin{array}{l}\text { Bottom } \\
(\mathrm{m})\end{array}$ & Simplified lithology & Driller's description \\
\hline Law Eng 103 & 0.76 & 1.52 & clay, sand and gravel & $\begin{array}{l}\text { Silty sands, dense brown sandy silt with gravel, } \\
\text { noncemented. }\end{array}$ \\
\hline Law Eng 103 & 1.52 & 3.05 & sand, clay and gravel & $\begin{array}{l}\text { Silty sands, very dense brown gravel and silty very fine } \\
\text { sand, noncemented. }\end{array}$ \\
\hline Law Eng 103 & 3.05 & 5.49 & sand, clay and gravel & $\begin{array}{l}\text { Silty gravel, very dense brown-tan sand with gravel and } \\
\text { silt,. }\end{array}$ \\
\hline Law Eng 103 & 5.49 & 7.92 & sand, clay and gravel & $\begin{array}{l}\text { Silty sands-silty gravel, very dense brown-tan sand with } \\
\text { gravel and silt, noncemented. }\end{array}$ \\
\hline Law Eng 103 & 7.92 & 13.41 & sand, clay and gravel & Very dense tan silty sand with gravel, partially cemented. \\
\hline Law Eng 103 & 13.41 & 19.81 & sand, clay and gravel & $\begin{array}{l}\text { Silty sands-silty gravel, very dense brown silty fine to } \\
\text { coarse gravel with fine to coarse sand and trace of clay } \\
\text { in partially cemented matrix. }\end{array}$ \\
\hline Law Eng 103 & 19.81 & 21.95 & sand, clay and gravel & $\begin{array}{l}\text { Silty sands-silty gravel, very dense brown silty fine to } \\
\text { coarse gravel with fine to coarse sand and trace of clay } \\
\text { in partially cemented matrix. }\end{array}$ \\
\hline Law Eng 103 & 21.95 & 24.38 & sand, clay and gravel & $\begin{array}{l}\text { Silty sands, very dense brown-orange silty gravelly sand } \\
\text { within a clayey silt matrix. }\end{array}$ \\
\hline Law Eng 103 & 24.38 & 30.48 & sand, clay and gravel & $\begin{array}{l}\text { Silty sands, very dense brown-orange silty gravelly sand } \\
\text { within a clayey silt matrix. Boring terminated at } 100 \mathrm{ft} \text {. }\end{array}$ \\
\hline Law Eng 104 & 0.00 & 1.52 & sand, clay and gravel & Silty sands, brown silt with fine sand and gravel. \\
\hline Law Eng 104 & 1.52 & 2.44 & sand, clay and gravel & $\begin{array}{l}\text { Silty sands/silty gravel, brown silty sand and gravel, non- } \\
\text { cemented. }\end{array}$ \\
\hline Law Eng 104 & 2.44 & 7.92 & sand, clay and gravel & $\begin{array}{l}\text { Silty sands/silty gravel, very dense gray-tan silt and } \\
\text { gravel with occasional cobble, noncemented to partially } \\
\text { cemented. }\end{array}$ \\
\hline Law Eng 104 & 7.92 & 14.02 & sand, clay and gravel & $\begin{array}{l}\text { Silty sands, very dense gray-tan silty and sand with fine } \\
\text { gravel, noncemented. At } 45 \mathrm{ft} \text { cobbles encountered. }\end{array}$ \\
\hline Law Eng 104 & 14.02 & 22.86 & sand, clay and gravel & $\begin{array}{l}\text { Silty sands, very dense gray-tan silty sand with gravel, } \\
\text { partially cemented. }\end{array}$ \\
\hline Law Eng 104 & 22.86 & 24.38 & clay, sand and gravel & $\begin{array}{l}\text { Sandy clay, very dense orange-brown fine to coarse sand } \\
\text { and gravel in clay (orange) matrix, well cemented. }\end{array}$ \\
\hline
\end{tabular}


Appendix 1. Compilation of borehole and aquifer data.-Continued

[cm, centimeter; $\mathrm{m}$, meter; in, inch; $\mathrm{ft}$, feet; $\%$, percent; ppm, parts per million; $\approx$, approximately equal to; >, greater than]

\begin{tabular}{ccccc}
\hline Bore & $\begin{array}{c}\text { Top } \\
(\mathbf{m})\end{array}$ & $\begin{array}{c}\text { Bottom } \\
(\mathbf{m})\end{array}$ & Simplified lithology & Driller's description \\
\hline Law Eng 104 & 24.38 & 26.82 & clay, sand and gravel & $\begin{array}{c}\text { Sandy clay, very dense orange-brown fine to coarse sand } \\
\text { and gravel in clay (orange) matrix, well cemented. }\end{array}$ \\
Law Eng 104 & 26.82 & 47.55 & clay, sand and gravel & $\begin{array}{c}\text { Sandy clay, very dense orange-brown fine to coarse sand } \\
\text { and gravel in clay (orange) matrix, well cemented. At } \\
100 \mathrm{ft} \text { greater percent clay matrix. At } 120 \mathrm{ft} \text {, occurrence } \\
\text { of cobbles in some layers. At } 140 \mathrm{ft} \text { less percent clay } \\
\text { matrix. Boring terminated at } 156 \mathrm{ft} .\end{array}$
\end{tabular}

Law Eng 105

Law Eng 105

Law Eng 105

Law Eng 105

Law Eng 105

Law Eng 105

Law Eng 105

Law Eng 105

Law Eng 105

Law Eng 106

Law Eng 106

0.91

Law Eng 106
2.13

sand, clay and gravel

1.07 sand and clay

4.27 sand, clay and gravel

7.62 clay, sand and gravel

10.36 sand, clay and gravel

12.80 sand, clay and gravel

15.24 sand, clay and gravel

24.38

sand, clay and gravel

sand, clay and gravel

sand and clay

clay, sand and trace gravel

7.32 sand, clay and gravel
Silty sands, very dense brown silty sand, noncemented.

Silty gravel, very dense gray silty sandy gravel with occasional cobbles, noncemented.

Silty sands, very dense brown sandy silt with gravel and occasional cobbles, noncemented.

Silty gravel, very dense gray-brown silty sandy gravel with cobbles, noncemented to well-cemented.

Silty sands, very dense brown silty sand with scattered gravel, partial cementation grading to well-cemented with depth.

Silty sands, very dense tan silty sand with gravel, noncemented.

Silty sands/silty gravel, very dense gray-tan silty sand and gravel, scattered cobbles, partially cemented.

Silty sands/silty gravel, very dense dark gray-brown silty sand and gravel, noncemented.

Silty sands, very dense gray-tan silty sand, well cemented. Boring terminated at $99 \mathrm{ft}$.

Silty sands, dense brown sandy silt with scattered gravel and cobbles, noncemented.

Silty gravel, dense brown silty sandy gravel with cobbles, noncemented.

Silty sands, very dense gray-tan silty sand with fine gravel, partially cemented. 
Appendix 1. Compilation of borehole and aquifer data.-Continued

[cm, centimeter; $\mathrm{m}$, meter; in, inch; ft, feet; \%, percent; ppm, parts per million; $\approx$, approximately equal to; >, greater than]

\begin{tabular}{|c|c|c|c|c|}
\hline Bore & $\begin{array}{l}\text { Top } \\
\text { (m) }\end{array}$ & $\begin{array}{l}\text { Bottom } \\
(\mathrm{m})\end{array}$ & Simplified lithology & Driller's description \\
\hline Law Eng 106 & 7.32 & 11.58 & sand, clay and gravel & $\begin{array}{l}\text { Silty gravel, very dense gray-tan silty sandy gravel with } \\
\text { cobbles, noncemented. }\end{array}$ \\
\hline Law Eng 106 & 11.58 & 18.29 & sand, clay and gravel & $\begin{array}{l}\text { Silty sands, very dense brown silty sand with gravel and } \\
\text { occasional cobbles, noncemented. }\end{array}$ \\
\hline Law Eng 106 & 18.29 & 24.38 & $\begin{array}{l}\text { sand, clay and trace } \\
\text { gravel }\end{array}$ & $\begin{array}{l}\text { Silty sands, very dense gray-tan silty sand with scattered } \\
\text { gravel and occasional cobbles, well cemented. }\end{array}$ \\
\hline Law Eng 106 & 24.38 & 27.43 & $\begin{array}{l}\text { sand, clay and trace } \\
\text { gravel }\end{array}$ & $\begin{array}{l}\text { Silty sands, very dense gray-tan silty sand with scattered } \\
\text { gravel and occasional cobbles, well cemented. }\end{array}$ \\
\hline Law Eng 106 & 42.06 & 48.77 & sand and gravel & $\begin{array}{l}\text { Silty sands/silty gravel, very dense tan to brown sand and } \\
\text { gravel, noncemented. Boring terminated at } 160 \mathrm{ft} \text {. }\end{array}$ \\
\hline Law Eng 107 & 0.00 & 1.22 & clay and sand & Silty sands, firm brown sandy silt, noncemented. \\
\hline Law Eng 107 & 1.22 & 2.44 & sand, clay and gravel & Silty gravel, dense brown silty sandy gravel, noncemented. \\
\hline Law Eng 107 & 2.44 & 6.10 & sand, clay and gravel & $\begin{array}{l}\text { Silty sands, very dense brown silty sand and gravel scat- } \\
\text { tered cobbles, partially cemented. }\end{array}$ \\
\hline Law Eng 107 & 20.73 & 22.71 & sand, clay and gravel & $\begin{array}{l}\text { Silty sands/silty gravel, very dense tan silty sand and fine } \\
\text { gravel, well cemented. Boring terminated at } 74.5 \mathrm{ft} \text {,. }\end{array}$ \\
\hline Law Eng 301 & 0.00 & 3.05 & sand, clay and gravel & $\begin{array}{l}\text { Brown silty sandy gravel and cobbles, noncemented. } \\
\text { Remarks, rock fragments (sand, gravel, cobbles, and } \\
\text { boulders) are of intermediate (andesitic or dioritic), } \\
\text { felsic (rhyolitic), and, mafic (basaltic) compositions. }\end{array}$ \\
\hline Law Eng 301 & 3.05 & 6.10 & sand, clay and gravel & Brown silty sand with gravel, noncemented. \\
\hline Law Eng 301 & 6.10 & 9.14 & sand, clay and gravel & Brown silty sandy gravel and cobbles, noncemented. \\
\hline
\end{tabular}


Appendix 1. Compilation of borehole and aquifer data.-Continued

[cm, centimeter; $\mathrm{m}$, meter; in, inch; ft, feet; \%, percent; ppm, parts per million; $\approx$, approximately equal to; >, greater than]

\begin{tabular}{|c|c|c|c|c|}
\hline Bore & $\begin{array}{l}\text { Top } \\
\text { (m) }\end{array}$ & $\begin{array}{l}\text { Bottom } \\
\text { (m) }\end{array}$ & Simplified lithology & Driller's description \\
\hline Law Eng 301 & 9.14 & 35.05 & clay, sand and gravel & $\begin{array}{l}\text { Brown sandy silt and silty sandy gravel with cobbles, } \\
\text { noncemented. }\end{array}$ \\
\hline Law Eng 301 & 35.05 & 48.77 & sand, clay and gravel & $\begin{array}{l}\text { Brown silty sand with gravel. Becomes finer with depth. } \\
\text { Partially to well-cemented with noncemented zones. }\end{array}$ \\
\hline Law Eng 301 & 48.77 & 62.48 & sand, clay and gravel & $\begin{array}{l}\text { Alternating brown silty sandy gravel with cobbles and } \\
\text { brown sandy clayey silt. At } 180 \mathrm{ft} \text { partially to well- } \\
\text { cemented. }\end{array}$ \\
\hline Law Eng 301 & 62.48 & 67.06 & sand, clay and gravel & Brown sandy clayey silt, well cemented. \\
\hline Law Eng 301 & 79.25 & 91.44 & sand, clay and gravel & $\begin{array}{l}\text { Alternating brown sandy clayey silt and brown silty sandy } \\
\text { gravel. At } 280 \mathrm{ft} \text { partially to well-cemented. }\end{array}$ \\
\hline Law Eng 301 & 91.44 & 97.54 & sand, clay and gravel & $\begin{array}{l}\text { Light brown and tan sandy clayey silt with coarse sand and } \\
\text { gravel, well cemented. }\end{array}$ \\
\hline Law Eng 301 & 97.54 & 103.63 & sand, clay and gravel & Color becomes yellow-brown below $325 \mathrm{ft}$. \\
\hline Law Eng 302 & 0.00 & 12.19 & sand, clay and gravel & $\begin{array}{l}\text { Brown silty clayey sandy gravel with cobbles. Remarks, } \\
\text { rock fragments (sand, gravel, cobbles, and boulders) are } \\
\text { of intermediate (andesitic or dioritic), felsic (rhyolitic), } \\
\text { and, mafic (basaltic) composition. }\end{array}$ \\
\hline Law Eng 302 & 12.19 & 27.43 & clay, sand and gravel & Brown sandy silt with gravel and occasional cobbles. \\
\hline Law Eng 302 & 27.43 & 39.62 & sand, clay and gravel & Brown clayey silty sand with gravel and cobbles. \\
\hline Law Eng 302 & 39.62 & 48.77 & sand, clay and gravel & Brown sandy gravel with cobbles and a trace of silty clay. \\
\hline Law Eng 302 & 48.77 & 60.96 & clay, sand and gravel & Brown sandy silt with clay and gravel, occasional cobbles. \\
\hline
\end{tabular}


Appendix 1. Compilation of borehole and aquifer data.-Continued

[cm, centimeter; m, meter; in, inch; ft, feet; \%, percent; ppm, parts per million; $\approx$, approximately equal to; $>$, greater than]

\begin{tabular}{|c|c|c|c|c|}
\hline Bore & $\begin{array}{l}\text { Top } \\
\text { (m) }\end{array}$ & $\begin{array}{l}\text { Bottom } \\
(\mathrm{m})\end{array}$ & Simplified lithology & Driller's description \\
\hline Law Eng 302 & 60.96 & 77.72 & sand and gravel & $\begin{array}{l}\text { Light brown sandy coarse gravel and cobbles with } \\
\text { boulders. }\end{array}$ \\
\hline Law Eng 302 & 77.72 & 85.34 & sand, clay and gravel & $\begin{array}{l}\text { Light brown clayey silty sand with gravel and occasional } \\
\text { cobbles. }\end{array}$ \\
\hline Law Eng 302 & 85.34 & 97.54 & sand, clay and gravel & $\begin{array}{l}\text { Brown coarse sandy gravel with cobbles and boulders in a } \\
\text { clayey silty fine sand matrix. }\end{array}$ \\
\hline Law Eng 302 & 97.54 & 108.20 & sand, clay and gravel & $\begin{array}{l}\text { Brown coarse sandy gravel with cobbles and boulders in a } \\
\text { clayey silty fine sand matrix. Bottomed at } 355 \mathrm{ft} \text {. }\end{array}$ \\
\hline Law Eng 303 & 10.67 & 13.72 & sand, clay and gravel & Brown sandy gravel with trace of silty clay. \\
\hline Law Eng 303 & 13.72 & 25.91 & sand, clay and gravel & Brown clayey silty sand and gravel with cobbles. \\
\hline Law Eng 303 & 25.91 & 33.53 & sand, clay and gravel & Brown sandy gravel and cobbles with trace silty clay. \\
\hline Law Eng 303 & 79.25 & 94.49 & sand, clay and gravel & Brown to red sandy clayey silt with coarse sand and gravel. \\
\hline Law Eng 303 & 94.49 & 97.54 & sand, clay and gravel & $\begin{array}{l}\text { Yellow to light brown silty clay with coarse sand and } \\
\text { gravel. }\end{array}$ \\
\hline Law Eng 303 & 97.54 & 106.68 & sand, clay and gravel & $\begin{array}{l}\text { Yellow to light brown silty clay with coarse sand and } \\
\text { gravel. Bottomed at } 350 \mathrm{ft} \text {. }\end{array}$ \\
\hline Law Eng Trench 10-1 & 0.00 & 0.61 & sand and clay & $\begin{array}{l}\text { Silty sands, loose light brown calcareous silty sand and } \\
\text { sand silt with roots. }\end{array}$ \\
\hline Law Eng Trench 10-1 & 0.61 & 3.35 & sand, clay and gravel & $\begin{array}{l}\text { Gravel, little or no fines, dense and very dense brown silty } \\
\text { gravelly sand and sandy gravel. Loosely cemented to } \\
\text { uncemented, some calcareous cementation. Generally } \\
\text { massive. }\end{array}$ \\
\hline
\end{tabular}


Appendix 1. Compilation of borehole and aquifer data.-Continued

[cm, centimeter; $\mathrm{m}$, meter; in, inch; ft, feet; \%, percent; ppm, parts per million; $\approx$, approximately equal to; >, greater than ]

\begin{tabular}{ccccc}
\hline Bore & $\begin{array}{c}\text { Top } \\
(\mathbf{m})\end{array}$ & $\begin{array}{c}\text { Bottom } \\
(\mathbf{m})\end{array}$ & Simplified lithology & Driller's description \\
\hline Law Eng Trench 10-1 & 3.35 & 5.49 & clay, sand and gravel & $\begin{array}{c}\text { Silty sands, very hard light brown sandy silt and silty } \\
\text { sand with sandy gravel lenses. Moderately-well to well } \\
\text { cemented with discontinuous inrock-likein caliche zones } \\
\text { throughout. Remarks, Grain size. }\end{array}$ \\
\hline
\end{tabular}

Law Eng Trench 10-1 $\quad 5.49 \quad 8.53 \quad$ sand, clay and gravel

Law Eng Trench 10-1 $\quad 5.49 \quad 8.53 \quad$ sand, clay and gravel

Law Eng Trench 10-1 $\quad 8.53 \quad 9.45 \quad$ sand and clay

Law Eng Trench 10-1

9.45

12.19

sand, clay and gravel

Law Eng Trench 10-1

12.19

12.80

sand, clay and gravel

Law Eng Trench 10-1

12.80

18.29

sand, clay and gravel

Law Eng Trench $22-1 \mathrm{~N}$

Law Eng Trench $22-1 \mathrm{~N}$

Law Eng Trench $22-1 \mathrm{~N}$
3.96
0.61

sand, clay and gravel 3.96 sand, clay and gravel

0.61

Gravel, little or no fines, dense brown silty sandy gravel and cobbles with some cross-bedded silty sand lenses. Loosely cemented to uncemented, some calcareous zones.

Silty sands, very hard light brown, sandy silt and silty sand with gravel and cobble lenses. Moderately well cemented with some calcareous zones in the upper part. Grain size. 
Appendix 1. Compilation of borehole and aquifer data.-Continued

[cm, centimeter; m, meter; in, inch; ft, feet; \%, percent; ppm, parts per million; $\approx$, approximately equal to; $>$, greater than]

\begin{tabular}{|c|c|c|c|c|}
\hline Bore & $\begin{array}{l}\text { Top } \\
\text { (m) }\end{array}$ & $\begin{array}{l}\text { Bottom } \\
\text { (m) }\end{array}$ & Simplified lithology & Driller's description \\
\hline $\begin{array}{l}\text { Law Eng Trench } \\
\text { 22-1N }\end{array}$ & 7.77 & 11.43 & sand, clay and gravel & $\begin{array}{l}\text { Gravel, little or no fines, very dense brown sandy gravel } \\
\text { and cobbles with cross-bedded silty sand and sandy } \\
\text { gravel lenses. Moderately well to loosely cemented. } \\
\text { Frequent occurrences of manganese-stained lenses. }\end{array}$ \\
\hline $\begin{array}{l}\text { Law Eng Trench } \\
22-1 \mathrm{~N}\end{array}$ & 12.19 & 16.00 & clay, sand and gravel & $\begin{array}{l}\text { Silty gravel/silty sands, alternating layers and lenses of } \\
\text { gravel and cobbles in a very hard light brown sandy silt } \\
\text { and silty sand matrix and very dense sandy gravel and } \\
\text { gravelly cobbles. Moderately-well and well-cemented } \\
\text { intervals predominate, loosely-cemented and uncement- } \\
\text { ed in some cross-bedded sand lenses. Bottom of Trench, } \\
\text { North Side. }\end{array}$ \\
\hline
\end{tabular}

Law Eng Trench 22-2S

Law Eng Trench 22-2S

0.61

2.29

Law Eng Trench 22-2S

2.29

8.99

clay, sand and gravel

Law Eng Trench 22-2S

8.99

11.73

sand, clay and gravel

Law Eng Trench 22-2S

11.73

12.19

Law Eng Trench 22-2S

12.19

15.39

clay, sand and gravel

Law Eng Trench 22-2S

15.39

17.37

sand, clay and gravel

Law Eng Trench

22-3W
0.00

0.61 sand and clay
Silty sands, inloosein light brown calcareous silty sand and sandy silt. Remarks, grain size.

Gravel, little or no fines, loose to dense brown and gray sandy gravel and cobbles, occasional lenses or zone is calcareous, loosely-cemented to uncemented.

Silty sands, very hard light brown gravelly sandy silt and silty sand with sandy gravel and cobble lenses and layers. Silt and sand matrix is massively bedded and moderately well cemented. Remarks, Grain size.

Gravel, little or no fines, very dense gray-brown silty sandy gravel, cobbles, and boulders. Thick to thin bedded and cross-bedded manganese-strained lenses dispersed throughout. Moderately well cemented to uncemented. Remarks, Grain size.

Distinct and highly irregular unconformable contact.

Silty sands, very hard light brown gravelly sandy silt with cobbles. Massive to thickly bedded, moderately-well cemented. Remarks, grain size.

Silty sands/silty gravel, dense and very dense brown silty gravelly sand with cobbles and thin silty sand lenses. Medium to thin bedded cross beds in fine lenses. Moderately well cemented. Bottom of Trench, south side, $57 \mathrm{ft}$ Remarks, grain size.

Silty sands, loose light brown calcareous silty sand and sandy silt, roots. 
Appendix 1. Compilation of borehole and aquifer data.-Continued

[cm, centimeter; $\mathrm{m}$, meter; in, inch; ft, feet; \%, percent; ppm, parts per million; $\approx$, approximately equal to; >, greater than]

\begin{tabular}{|c|c|c|c|c|}
\hline Bore & $\begin{array}{l}\text { Top } \\
\text { (m) }\end{array}$ & $\begin{array}{c}\text { Bottom } \\
\text { (m) }\end{array}$ & Simplified lithology & Driller's description \\
\hline $\begin{array}{l}\text { Law Eng Trench } \\
\text { 22-3W }\end{array}$ & 0.61 & 1.98 & sand, clay and gravel & $\begin{array}{l}\text { Gravel, little or no fines, dense brown sandy gravel and } \\
\text { cobbles with some silty sand and sandy gravel lenses. } \\
\text { Massive bedding except in fine-grained, thin to mediur } \\
\text { bedded lenses. At } 6.5 \mathrm{ft} \text { loosely to uncemented. Some } \\
\text { calcareous zones. }\end{array}$ \\
\hline $\begin{array}{l}\text { Law Eng Trench } \\
\text { 22-3W }\end{array}$ & 1.98 & 6.71 & clay, sand and gravel & $\begin{array}{l}\text { Silty sands, very hard light brown gravelly sandy silt and } \\
\text { silty sand with frequent layers of gravel and cobbles in } \\
\text { a sand/silt matrix. Massive to medium bedded in grave } \\
\text { cobble lenses. Moderately well cemented to loosely } \\
\text { cemented in upper } 2 \mathrm{ft} \text {. }\end{array}$ \\
\hline $\begin{array}{l}\text { Law Eng Trench } \\
22-3 \mathrm{~W}\end{array}$ & 6.71 & 10.36 & sand, clay and gravel & $\begin{array}{l}\text { Silty gravel, very dense brown silty sandy gravel and } \\
\text { cobbles, generally massive except in silty sand and } \\
\text { sandy gravel. Lenses which are thin and cross-bedded, } \\
\text { moderately well cemented. More fines here than in } \\
\text { this layer in other walls. At } 34 \mathrm{ft} \text { distinct and irregular } \\
\text { unconformable contact. }\end{array}$ \\
\hline $\begin{array}{l}\text { Law Eng Trench } \\
22-3 \mathrm{~W}\end{array}$ & 10.36 & 10.67 & sand, clay and gravel & $\begin{array}{l}\text { Silty sands/silty gravel, very hard light brown sand, grav } \\
\text { and cobbles in silt-sand matrix. Moderately well ce- } \\
\text { mented. Bottom of Trench, west side. }\end{array}$ \\
\hline Law Eng W-2 & 0.00 & 6.10 & sand, clay and gravel & $\begin{array}{l}\text { Brown clayey silty sand and gravel, occasional cobbles. } \\
\text { Remarks, rock fragments (sand, gravel, cobbles, and } \\
\text { boulders) are of intermediate (andesitic or dioritic), } \\
\text { felsic (rhyolitic), and mafic (basaltic) composition. }\end{array}$ \\
\hline
\end{tabular}

Law Eng W-2

Law Eng W-2

Law Eng W-2

Law Eng W-2

Law Eng W-2

Law Eng W-2

57.91

80.77

sand and gravel

Law Eng W-2

80.77

86.87
Brown sandy fine to coarse gravel with cobbles.

Brown clayey silty sand with gravel and cobbles.

Brown clayey silty sand with gravel and cobbles.

Brown sandy silt with clay and gravel with occasional cobbles.

Brown sandy gravel with trace silty clay, and occasional cobbles.

Brown sandy coarse gravel with cobbles and boulders. Remarks, rock fragments below $\approx 210 \mathrm{ft}$ react with 0.10 molar $\mathrm{HCl}$ acid, calcite believed to be disseminated within or adhering to the silicic rock fragments.

Light brown to tan clayey silty sand with gravel, cobbles, and some boulders. 
Appendix 1. Compilation of borehole and aquifer data.-Continued

[cm, centimeter; $\mathrm{m}$, meter; in, inch; $\mathrm{ft}$, feet; \%, percent; ppm, parts per million; $\approx$, approximately equal to; >, greater than]

\begin{tabular}{|c|c|c|c|c|}
\hline Bore & $\begin{array}{l}\text { Top } \\
\text { (m) }\end{array}$ & $\begin{array}{l}\text { Bottom } \\
(\mathrm{m})\end{array}$ & Simplified lithology & Driller's description \\
\hline Law Eng W-2 & 86.87 & 97.54 & sand, clay and gravel & $\begin{array}{l}\text { Brown coarse sandy gravel with cobbles and boulders in a } \\
\text { light brown to tan clayey silty fine sand matrix. }\end{array}$ \\
\hline Law Eng W-2 & 97.54 & 111.25 & sand, clay and gravel & $\begin{array}{l}\text { Brown coarse sandy gravel with cobbles and boulders in } \\
\text { a light brown to tan clayey silty fine sand matrix. Bot- } \\
\text { tomed at } 365 \mathrm{ft} \text {. }\end{array}$ \\
\hline Mark Group 308 & 0.00 & 12.19 & sand, clay and gravel & $\begin{array}{l}\text { No data. } 40 \mathrm{ft} \text { of surface casing previously installed } \\
\text { ( } 121 / 4 \text { in diameter) elevation of measuring point is top } \\
\text { of casing. Height of measuring point above land surface } \\
\text { is } 1.54 \mathrm{ft} \text {. }\end{array}$ \\
\hline Mark Group 308 & 16.15 & 22.25 & sand and gravel & $\begin{array}{l}\text { Coarse sand with } 15 \% \text { cobbles, well graded, reddish } \\
\text { brown, subrounded to subangular, some angular, rig } \\
\text { chatter. }\end{array}$ \\
\hline Mark Group 308 & 22.25 & 25.30 & sand and gravel & $\begin{array}{l}\text { Fine to coarse sand with minor gravel, well graded, reddish } \\
\text { brown subrounded to angular, rig chatter. }\end{array}$ \\
\hline Mark Group 308 & 25.30 & 28.35 & sand and trace gravel & $\begin{array}{l}\text { Gravelly sand, well graded, reddish brown, minor cobble, } \\
\text { subrounded to angular. }\end{array}$ \\
\hline Mark Group 308 & 34.14 & 35.97 & $\begin{array}{l}\text { sand, clay and trace } \\
\text { gravel }\end{array}$ & (Resume drilling starting depth $110 \mathrm{ft}$ ). \\
\hline Mark Group 308 & 35.97 & 39.01 & sand & $\begin{array}{l}\text { Fine to medium sand, reddish brown, subangular, some } \\
\text { larger/coarser sand, no gravel. }\end{array}$ \\
\hline Mark Group 308 & 39.01 & 43.28 & sand and trace gravel & $\begin{array}{l}\text { Fine to medium sand with trace gravel, reddish, brown, } \\
\text { gravel is angular, } 1 / 2 \text { in diameter. }\end{array}$ \\
\hline Mark Group 308 & 43.28 & 45.72 & sand & $\begin{array}{l}\text { Gravelly fine to medium sand, reddish brown, angular to } \\
\text { subangular, } \approx 10-20 \% \text { gravel } 1 / 4-1 / 2 \text { in diameter. }\end{array}$ \\
\hline Mark Group 308 & 45.72 & 49.38 & sand & $\begin{array}{l}\text { Gravelly fine to medium sand, reddish brown, angular- } \\
\text { subangular, some coarse sand }(\approx 1 \%), \approx 10-20 \% \text { gravel } \\
1 / 4-1 / 2 \text { in diameter. }\end{array}$ \\
\hline
\end{tabular}


Appendix 1. Compilation of borehole and aquifer data.-Continued

[cm, centimeter; $\mathrm{m}$, meter; in, inch; ft, feet; \%, percent; ppm, parts per million; $\approx$, approximately equal to; >, greater than]

\begin{tabular}{|c|c|c|c|c|}
\hline Bore & $\begin{array}{l}\text { Top } \\
\text { (m) }\end{array}$ & $\begin{array}{l}\text { Bottom } \\
(\mathrm{m})\end{array}$ & Simplified lithology & Driller's description \\
\hline Mark Group 308 & 49.38 & 51.82 & sand and gravel & $\begin{array}{l}\text { Sandy gravel, sand fine-medium subangular, gravel } \\
\text { medium-coarse } 1 / 4-3 / 4 \text { in diameter, reddish brown } \\
\text { (166 ft, rig chatter). }\end{array}$ \\
\hline Mark Group 308 & 51.82 & 54.86 & sand and gravel & $\begin{array}{l}\text { Sand gravel, sand fine-medium subangular, gravel medi- } \\
\text { um-coarse } 1 / 4-3 / 4 \text { in diameter, reddish brown. }\end{array}$ \\
\hline Mark Group 308 & 54.86 & 57.91 & sand and trace gravel & $\begin{array}{l}\text { Gravelly sand, sand mainly fine-grained to very fine- } \\
\text { grained, } 10 \% 1 / 4 \text { diameter }(>1 / 2 \text { in } 1 \%) \text {, brown. }\end{array}$ \\
\hline Mark Group 308 & 57.91 & 60.96 & sand and gravel & $\begin{array}{l}\text { Sand gravel, angular to subangular, sand very fine to coarse } \\
\text { ( } 40 \% \text { fine, } 10 \% \text { coarse, } 50 \% \text { fine-medium), gravel is } \\
\text { fine-medium grain, brown. }\end{array}$ \\
\hline Mark Group 308 & 60.96 & 64.01 & $\begin{array}{l}\text { sand, clay and trace } \\
\text { gravel }\end{array}$ & $\begin{array}{l}\text { Gravelly sand, well graded, very fine to medium sand, } \\
\text { gravel fine-medium grain, } \approx 10-20 \% \text { to } 1 / 4 \text { in diameter, } \\
\text { few clay balls present, reddish brown. }\end{array}$ \\
\hline Mark Group 308 & 64.01 & 67.06 & sand and trace gravel & Fine to medium sand, very little gravel, reddish brown. \\
\hline Mark Group 308 & 67.06 & 70.10 & sand and trace gravel & $\begin{array}{l}\text { Fine to medium sand, very little gravel }(<1 \%) \text {, probably } \\
\text { residual material, reddish brown. }\end{array}$ \\
\hline Mark Group 308 & 70.10 & 73.15 & sand and trace gravel & $\begin{array}{l}\text { Gravelly sand, sand well graded, very fine-medium } \\
\text { angular-subangular, reddish brown. }\end{array}$ \\
\hline Mark Group 308 & 76.20 & 79.25 & sand and trace gravel & $\begin{array}{l}\text { Gravelly sand, sand medium to fine-grained, mainly fine- } \\
\text { grained, }(60 \%), 30 \% \text { gravel } 1 / 4-1 / 2 \text { in diameter, reddish } \\
\text { brown. }\end{array}$ \\
\hline Mark Group 308 & 79.25 & 82.30 & sand and trace gravel & $\begin{array}{l}\text { Gravelly sand, sand medium to fine-grained, mainly fine- } \\
\text { grained, } \approx 20-30 \% \text { gravel } 1 / 4-1 / 2 \text { in diameter, reddish } \\
\text { brown, few clay balls present. }\end{array}$ \\
\hline Mark Group 308 & 82.30 & 85.34 & sand and trace gravel & $\begin{array}{l}\text { Gravelly sand, sand medium to fine-grained, mainly fine- } \\
\text { grained, } \approx 20-30 \% \text { gravel } 1 / 8-1 / 4 \text { in diameter, reddish } \\
\text { brown. }\end{array}$ \\
\hline Mark Group 308 & 85.34 & 88.39 & sand, clay and gravel & $\begin{array}{l}\text { Gravelly clayey sand, sand, very fine-medium grain, } \\
\text { mainly fine-grained, some clay balls present after wash- } \\
\text { ing, gravel fine-grained, } 1 / 8 \text { in diameter reddish brown. }\end{array}$ \\
\hline
\end{tabular}


Appendix 1. Compilation of borehole and aquifer data.-Continued

[cm, centimeter; $\mathrm{m}$, meter; in, inch; $\mathrm{ft}$, feet; \%, percent; ppm, parts per million; $\approx$, approximately equal to; >, greater than]

\begin{tabular}{|c|c|c|c|c|}
\hline Bore & $\begin{array}{l}\text { Top } \\
\text { (m) }\end{array}$ & $\begin{array}{l}\text { Bottom } \\
\text { (m) }\end{array}$ & Simplified lithology & Driller's description \\
\hline Mark Group 308 & 88.39 & 89.92 & sand and clay & $\begin{array}{l}\text { Sandy clay, sand, very fine to coarse }(\approx 30-45 \%) \text {, clay ap- } \\
\text { pears to be a silty clay, grayish brown. }\end{array}$ \\
\hline Mark Group 308 & 89.92 & 92.66 & $\begin{array}{l}\text { sand, clay and trace } \\
\text { gravel }\end{array}$ & $\begin{array}{l}\text { 290-295 sandy clay with some gravel, sand is very fine, } \\
\text { gravel 1/7 in diameter, grayish brown. Static water level } \\
\text { at } 303.04 \mathrm{ft} \text { Starting depth } 319 \mathrm{ft} \text { Total depth drilled } \\
338 \mathrm{ft} .\end{array}$ \\
\hline Mark Group 309 & 0.00 & 18.29 & $\begin{array}{l}\text { sand, clay and trace } \\
\text { gravel }\end{array}$ & $\begin{array}{l}\text { No data to } 60 \mathrm{ft} \text { of surface casing previously installed } \\
(121 / 4 \text { in diameter). Elevation unknown. Measuring } \\
\text { point is top of casing. Height of measuring point above } \\
\text { land surface is } 0.95 \mathrm{ft} \text {. }\end{array}$ \\
\hline Mark Group 309 & 18.90 & 21.95 & sand and gravel & $\begin{array}{l}\text { Sandy gravel, brown, poorly graded, well rounded to } \\
\text { subangular. }\end{array}$ \\
\hline Mark Group 309 & 21.95 & 24.38 & sand and gravel & $\begin{array}{l}\text { Sandy gravel, brown, moderately graded, subrounded to } \\
\text { subangular. }\end{array}$ \\
\hline Mark Group 309 & 24.38 & 27.43 & sand and gravel & Sandy gravel, brown, well graded, minor cobble. \\
\hline Mark Group 309 & 39.62 & 45.72 & sand and gravel & $\begin{array}{l}\text { Sandy gravel, brown, moderately graded, subrounded to } \\
\text { subangular. }\end{array}$ \\
\hline Mark Group 309 & 45.72 & 48.77 & $\begin{array}{l}\text { sand, clay and trace } \\
\text { gravel }\end{array}$ & $\begin{array}{l}\text { Silty sand, brown, well graded, coarse-grained with minor } \\
\text { gravel. }\end{array}$ \\
\hline Mark Group 309 & 48.77 & 54.86 & sand and gravel & $\begin{array}{l}\text { Sandy gravel, brown, moderately graded, subrounded to } \\
\text { subangular. }\end{array}$ \\
\hline Mark Group 309 & 54.86 & 57.91 & sand and gravel & $\begin{array}{l}\text { Sandy gravel, brown, well graded, subrounded to suban- } \\
\text { gular. }\end{array}$ \\
\hline Mark Group 309 & 57.91 & 60.96 & sand and gravel & Sandy gravel, brown, well graded, subangular to angular. \\
\hline
\end{tabular}


Appendix 1. Compilation of borehole and aquifer data.-Continued

[cm, centimeter; $\mathrm{m}$, meter; in, inch; $\mathrm{ft}$, feet; $\%$, percent; ppm, parts per million; $\approx$, approximately equal to; >, greater than]

\begin{tabular}{|c|c|c|c|c|}
\hline Bore & $\begin{array}{l}\text { Top } \\
\text { (m) }\end{array}$ & $\begin{array}{l}\text { Bottom } \\
\text { (m) }\end{array}$ & Simplified lithology & Driller's description \\
\hline Mark Group 309 & 60.96 & 64.01 & sand and gravel & $\begin{array}{l}\text { Sandy gravel, brown, well graded, subangular to } \\
\text { subangular. }\end{array}$ \\
\hline Mark Group 309 & 64.01 & 67.06 & sand and trace gravel & $\begin{array}{l}\text { Gravelly sand, brown, well graded, subangular to } \\
\text { subrounded. }\end{array}$ \\
\hline Mark Group 309 & 67.06 & 70.10 & sand and gravel & $\begin{array}{l}\text { sand, brown, well graded, fine to medium-grained with } \\
\text { minor gravel. }\end{array}$ \\
\hline Mark Group 309 & 70.10 & 73.15 & sand and trace gravel & $\begin{array}{l}\text { Gravelly sand, brown, well graded, subangular to } \\
\text { subrounded. }\end{array}$ \\
\hline Mark Group 309 & 76.20 & 82.30 & sand and trace gravel & $\begin{array}{l}\text { Gravelly sand, brown, well graded, subrounded to } \\
\text { subangular. }\end{array}$ \\
\hline Mark Group 309 & 82.30 & 85.34 & sand and trace gravel & $\begin{array}{l}\text { Gravelly sand, brown, well graded, decreasing gravel, } \\
\text { subrounded to subangular. }\end{array}$ \\
\hline Mark Group 309 & 85.34 & 88.39 & clay and sand & $\begin{array}{l}\text { Sandy silt, light brown, mod. Graded, subrounded to sub- } \\
\text { angular. Slow drilling. }\end{array}$ \\
\hline Mark Group 309 & 93.27 & 94.49 & sand and clay & $\begin{array}{l}\text { Started drilling from } 312.9 \mathrm{ft} \text {, on } 10-07 / 88 \text {. Lithology same } \\
\text { as previous interval. Total depth drilled } 328 \mathrm{ft}(7 / 12 / 88) \text {. }\end{array}$ \\
\hline Mark Group 310 & 0.00 & 9.14 & sand and clay & $\begin{array}{l}\text { No sample } 0-30 \mathrm{ft} \text { used only air, no foam, no return out } \\
\text { of discharge line. Installed } 40 \mathrm{ft} \text { of surface casing ( } 8 \text { in } \\
\text { diameter) for drilling } 8 \text { in diameter pilot hole. Drilling } \\
\text { depths are from land surface. }\end{array}$ \\
\hline Mark Group 310 & 9.14 & 12.19 & sand and gravel & $\begin{array}{l}\text { Light brown gravelly sand, sand well graded, fine to coarse } \\
\text { grain, gravel fine to coarse. }\end{array}$ \\
\hline Mark Group 310 & 12.19 & 15.24 & sand and gravel & (no return from discharge line after setting surface casing). \\
\hline Mark Group 310 & 15.24 & 18.29 & sand and gravel & $\begin{array}{l}\text { Light brown gravelly sand, well graded, sand fine to } \\
\text { coarse, predominantly medium-grained, gravel coarse- } \\
\text { grained. }\end{array}$ \\
\hline
\end{tabular}


Appendix 1. Compilation of borehole and aquifer data.-Continued

[cm, centimeter; $\mathrm{m}$, meter; in, inch; ft, feet; \%, percent; ppm, parts per million; $\approx$, approximately equal to; >, greater than]

\begin{tabular}{|c|c|c|c|c|}
\hline Bore & $\begin{array}{l}\text { Top } \\
(\mathrm{m})\end{array}$ & $\begin{array}{l}\text { Bottom } \\
(\mathrm{m})\end{array}$ & Simplified lithology & Driller's description \\
\hline Mark Group 310 & 18.29 & 21.34 & sand and trace gravel & $\begin{array}{l}\text { Brownish sand with some gravel, well graded, sand } \\
\text { fine-medium-grained, gravel fine-grained } 1 / 8-1 / 4 \text { in } \\
\text { diameter. }\end{array}$ \\
\hline Mark Group 310 & 21.34 & 24.38 & sand, clay and gravel & $\begin{array}{l}\text { Brown gravelly sand, well graded, sand fine-medium grain, } \\
\text { gravel fine-medium-grained, mainly medium-grained } \\
1 / 4 \text { in diameter. }\end{array}$ \\
\hline Mark Group 310 & 24.38 & 27.43 & sand and gravel & $\begin{array}{l}\text { Brownish sandy gravel, well graded, sand fine to coarse- } \\
\text { grained, gravel medium-grained, } 1 / 2 \text { in diameter. }\end{array}$ \\
\hline Mark Group 310 & 30.48 & 33.53 & sand and gravel & $\begin{array}{l}\text { Brown sandy gravel, well graded, sand fine to coarse- } \\
\text { grained, mainly medium-grained, gravel fine to coarse, } \\
\text { mainly coarse-grained }>1 / 2 \text { in diameter. }\end{array}$ \\
\hline Mark Group 310 & 33.53 & 36.58 & sand and gravel & $\begin{array}{l}110 \mathrm{ft} \text {, brown gravelly sand, well graded, sand fine to } \\
\text { medium-grained, gravel is fine to coarse-grained. }\end{array}$ \\
\hline Mark Group 310 & 36.58 & 39.62 & sand & $\begin{array}{l}\text { Brownish gravelly sand, sand fine to medium-grained, } \\
\text { mainly medium-grained. }\end{array}$ \\
\hline Mark Group 310 & 45.72 & 51.82 & sand and gravel & $\begin{array}{l}\text { Brown sandy gravel, well graded, sand fine-medium- } \\
\text { grained, gravel medium-grained } 1 / 4-1 / 2 \text { in diameter. }\end{array}$ \\
\hline Mark Group 310 & 51.82 & 54.86 & sand and gravel & $\begin{array}{l}\text { Brown sand with gravel, well graded, sand fine to coarse, } \\
\text { mainly medium-grained, gravel medium-grained } \\
1 / 4-1 / 2 \text { in diameter. }\end{array}$ \\
\hline Mark Group 310 & 54.86 & 60.96 & sand, clay and gravel & $\begin{array}{l}\text { Brown sandy gravel, well graded, sand medium-grained, } \\
\text { gravel medium to coarse-grained } 1 / 4-1 / 2 \text { in diameter. }\end{array}$ \\
\hline Mark Group 310 & 60.96 & 64.01 & sand and gravel & $\begin{array}{l}\text { Brownish sandy gravel, well graded, sand fine to medium- } \\
\text { grained, mainly medium-grained, gravel medium- } \\
\text { grained, } 1 / 2 \text { in diameter. }\end{array}$ \\
\hline
\end{tabular}


Appendix 1. Compilation of borehole and aquifer data.-Continued

[cm, centimeter; $\mathrm{m}$, meter; in, inch; ft, feet; \%, percent; ppm, parts per million; $\approx$, approximately equal to; >, greater than]

\begin{tabular}{|c|c|c|c|c|}
\hline Bore & $\begin{array}{l}\text { Top } \\
\text { (m) }\end{array}$ & $\begin{array}{l}\text { Bottom } \\
\text { (m) }\end{array}$ & Simplified lithology & Driller's description \\
\hline Mark Group 310 & 64.01 & 67.06 & sand and trace gravel & $\begin{array}{l}\text { Brownish sand with some gravel, well graded, sand fine } \\
\text { to coarse-grained, gravel medium-grained } 1 / 8-1 / 4 \text { in } \\
\text { diameter. }\end{array}$ \\
\hline Mark Group 310 & 67.06 & 70.10 & sand, clay and gravel & $\begin{array}{l}\text { Brown gravel with some sand, gravel well graded, fine to } \\
\text { coarse, mainly coarse-grained, } 1 / 2 \text { in diameter. }\end{array}$ \\
\hline Mark Group 310 & 70.10 & 73.76 & sand and gravel & $\begin{array}{l}\text { Brownish sandy gravel, well graded, angular to subangular, } \\
\text { sand well graded and fine to medium-grained, gravel } \\
\text { graded from fine to medium } 1 / 8-1 / 2 \text { in diameter. }\end{array}$ \\
\hline Mark Group 310 & 76.20 & 79.25 & sand, clay and gravel & $\begin{array}{l}\text { Brown gravelly sand, sand well graded, fine to coarse- } \\
\text { grained, gravel medium-grained, } 1 / 4-1 / 2 \text { in diameter. }\end{array}$ \\
\hline Mark Group 310 & 79.25 & 82.30 & sand and gravel & $\begin{array}{l}\text { Brownish gravelly sand, well graded, sand fine-grained to } \\
\text { coarse-grained, gravel coarse-grained }>1 / 2 \text { in diameter. }\end{array}$ \\
\hline Mark Group 310 & 82.30 & 86.11 & clay and sand & $\begin{array}{l}\text { Grayish brown, sandy clay with some silt, sand fine- } \\
\text { grained. }\end{array}$ \\
\hline Mark Group 310 & 91.44 & 92.20 & sand and clay & Total Depth drilled, $302.5 \mathrm{ft}$. \\
\hline Mark Group 311 & 0.00 & 3.05 & sand and clay & $\begin{array}{l}\text { Installing } 40 \mathrm{ft} \text {, of } 121 / 4 \text { in diameter surface casing. Drill- } \\
\text { ing depth from land surface. Measuring point will be top } \\
\text { of casing. Height of casing above land surface is } 1.58 \mathrm{ft} \text {. }\end{array}$ \\
\hline Mark Group 311 & 3.05 & 6.10 & sand and gravel & $\begin{array}{l}\text { Brown, sandy gravel, poorly consolidated, medium to } \\
\text { coarse-grained sand, coarse-grained gravel, } 3 / 4 \text { in } \\
\text { diameter. }\end{array}$ \\
\hline Mark Group 311 & 6.10 & 9.14 & sand and gravel & $\begin{array}{l}\text { Brown, sandy gravel, medium to coarse sand, coarse } \\
\text { gravel, } 3 / 4 \text { in diameter. }\end{array}$ \\
\hline Mark Group 311 & 9.14 & 12.19 & sand and gravel & $\begin{array}{l}\text { Brown, sandy gravel, well graded, sand fine to coarse- } \\
\text { grained, coarse gravel. }\end{array}$ \\
\hline
\end{tabular}


Appendix 1. Compilation of borehole and aquifer data.-Continued

[cm, centimeter; m, meter; in, inch; ft, feet; \%, percent; ppm, parts per million; $\approx$, approximately equal to; $>$, greater than]

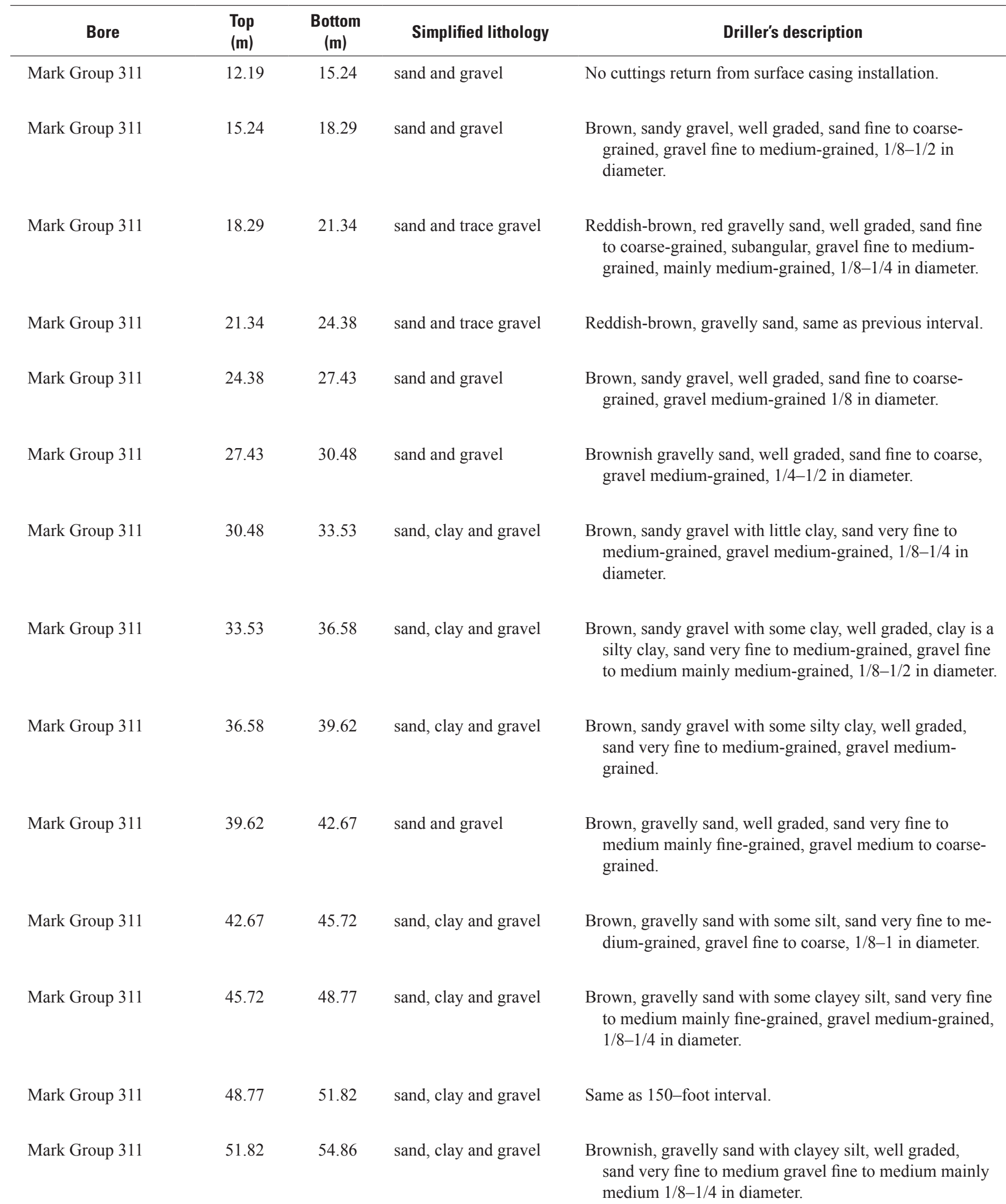


Appendix 1. Compilation of borehole and aquifer data.-Continued

[cm, centimeter; $\mathrm{m}$, meter; in, inch; ft, feet; \%, percent; ppm, parts per million; $\approx$, approximately equal to; >, greater than]

\begin{tabular}{ccccc}
\hline Bore & $\begin{array}{c}\text { Top } \\
(\mathbf{m})\end{array}$ & $\begin{array}{c}\text { Bottom } \\
(\mathbf{m})\end{array}$ & Simplified lithology & Driller's description \\
\hline Mark Group 311 & 54.86 & 57.91 & sand, clay and gravel & $\begin{array}{c}\text { Brownish, clayey gravelly sand, well graded, clay is a silty } \\
\text { clay, sand very fine to medium mainly fine-grained, } \\
\text { gravel fine to medium predominantly } 1 / 8-1 / 4 \text { in diam- } \\
\text { eter. }\end{array}$ \\
Mark Group 311 & & & sand and gravel & $\begin{array}{c}\text { Brown, sandy gravel, well graded, sand fine to coarse, } \\
\text { mainly medium gravel fine to medium } 1 / 6-1 / 4 \text { in } \\
\text { diameter. }\end{array}$ \\
Mark Group 311 & 60.96 & & sand and gravel & $\begin{array}{c}\text { Brown, sandy gravel, well graded, sand medium to coarse- } \\
\text { grained, gravel medium to coarse, } 1 / 6-3 / 4 \text { in diameter, } \\
\text { mainly } 1 / 2-3 / 4 \text { in diameter. }\end{array}$
\end{tabular}

Mark Group 311

Mark Group 311

67.06

70.10

sand, clay and gravel

Mark Group 311

Mark Group 311

73.15

76.20

sand, clay and gravel

Mark Group 311

76.20

79.25

sand and gravel

Mark Group 311

79.25

82.30

sand and gravel

Mark Group 311

82.30

85.34

sand and gravel

Mark Group 311

85.34

88.39

sand, clay and gravel

Mark Group 311

88.39

91.44

sand, clay and gravel

91.44

92.35

sand and clay
Brown, sandy gravel with some silty clay, sand medium to coarse-grained, gravel fine to medium-grained, $1 / 16-1 / 4$ in diameter.

Reddish-brown, gravel with some sand and silty clay, gravel well graded, angular to subangular, 1/16-1/2 in diameter.

Brown, sandy gravel, well graded, sand fine to mediumgrained, gravel medium to coarse, $1 / 8-1 / 2$ in diameter.

Brown, sandy gravel with some silty clay, well graded, sand is fine to coarse, gravel fine to coarse, $1 / 16-3 / 4$ in diameter.

Reddish brown, sand with gravel, sand is fine to coarsegrained, gravel medium-grained $1 / 8-1 / 4$ in diameter, no clay.

Brown, sandy gravel, well graded, sand fine to coarsegrained, gravel fine to medium-grained, $1 / 8-1 / 2$ in diameter.

Brown sand with some gravel, sand fine to coarse-grained, angular-subangular, gravel medium-grained, $\approx 1 / 4$ in diameter.

Brown, gravelly sand with some clayey silt, sand fine to coarse-grained, mainly fine-medium-grained, gravel medium-grained, $\approx 1 / 4$ in diameter.

Same as previous interval.

Grayish-brown, sand with silt, fine-grained. 
Appendix 1. Compilation of borehole and aquifer data.-Continued

[cm, centimeter; $\mathrm{m}$, meter; in, inch; ft, feet; \%, percent; ppm, parts per million; $\approx$, approximately equal to; >, greater than]

\begin{tabular}{|c|c|c|c|c|}
\hline Bore & $\begin{array}{l}\text { Top } \\
\text { (m) }\end{array}$ & $\begin{array}{l}\text { Bottom } \\
(\mathrm{m})\end{array}$ & Simplified lithology & Driller's description \\
\hline Mark Group 311 & 92.35 & 94.49 & sand and clay & $\begin{array}{l}\text { Start of drilling from } 303 \mathrm{ft} \text {, no water in borehole, drill } \\
\text { down } 5 \mathrm{ft} \text {. Static water level } 304.4 \mathrm{ft} \text {. }\end{array}$ \\
\hline Mark Group 311 & 94.49 & 97.54 & sand & $\begin{array}{l}\text { Reddish-brown, sand, sand medium-grained, subangular to } \\
\text { subrounded. }\end{array}$ \\
\hline Mark Group 311 & 97.54 & 100.58 & $\begin{array}{l}\text { sand, clay and trace } \\
\text { gravel }\end{array}$ & $\begin{array}{l}\text { Reddish-brown, sand with some silt and little gravel, sand } \\
\text { medium-grained, subangular to subrounded, silt ce- } \\
\text { mented. Rig on stand by to monitor water level. At } 330 \\
\text { greenish-brown, silt with some medium sand and fine } \\
\text { gravel, silt well cemented. Total depth drilled } 330 \mathrm{ft} \text {. }\end{array}$ \\
\hline Mark Group 312 & 13.72 & 15.24 & sand and gravel & $\begin{array}{l}\text { At } 45 \mathrm{ft} \text { sandy gravel, well graded, very little fines, clasts } \\
\text { predominantly volcanic tuffs and quartz. }\end{array}$ \\
\hline Mark Group 312 & 15.24 & 18.29 & sand and gravel & Sandy gravel, well graded. \\
\hline Mark Group 312 & 18.29 & 21.34 & sand and trace gravel & $\begin{array}{l}\text { Medium grain sand with } 10 \% \text { gravel, poorly graded, gravel } \\
\text { angular to subangular. }\end{array}$ \\
\hline Mark Group 312 & 27.43 & 28.65 & $\begin{array}{l}\text { sand, clay and trace } \\
\text { gravel }\end{array}$ & $\begin{array}{l}\text { Gravelly sand, reddish brown, fine-medium sand, some silt } \\
\text { washed away when dispersing foam, gravel } 1 / 4-1 / 2 \text { in } \\
\text { diameter. }\end{array}$ \\
\hline Mark Group 312 & 28.65 & 30.48 & $\begin{array}{l}\text { sand, clay and trace } \\
\text { gravel }\end{array}$ & Same, $\approx 3 \mathrm{ft}$ fill at bottom. \\
\hline Mark Group 312 & 30.48 & 33.53 & sand and gravel & $\begin{array}{l}\text { Gravelly fine-medium sand, gravel coarser } 1 / 4-3 / 4 \text { in, well } \\
\text { graded, brownish. }\end{array}$ \\
\hline Mark Group 312 & 33.53 & 36.27 & sand and gravel & $\begin{array}{l}\text { Medium sand to sandy gravel, sand poorly graded, gravel } \\
1 / 34-1 / 2 \text { in diameter. }\end{array}$ \\
\hline Mark Group 312 & 36.27 & 36.58 & sand & Medium gravelly sand, well graded. \\
\hline
\end{tabular}


Appendix 1. Compilation of borehole and aquifer data.-Continued

[cm, centimeter; $\mathrm{m}$, meter; in, inch; ft, feet; \%, percent; ppm, parts per million; $\approx$, approximately equal to; >, greater than]

\begin{tabular}{ccccc}
\hline Bore & $\begin{array}{c}\text { Top } \\
(\mathbf{m})\end{array}$ & $\begin{array}{c}\text { Bottom } \\
(\mathbf{m})\end{array}$ & Simplified lithology & Driller's description \\
\hline Mark Group 312 & 36.58 & 39.62 & sand and trace gravel & $\begin{array}{c}\text { Medium-coarse gravelly sand, well graded, sand fine- } \\
\text { medium mainly medium grain, many fines suspended in } \\
\text { foam. }\end{array}$ \\
\hline
\end{tabular}

\begin{tabular}{|c|c|c|c|c|}
\hline Mark Group 312 & 39.62 & 42.67 & sand and trace gravel & Medium-coarse gravelly sand, well graded. \\
\hline Mark Group 312 & 42.67 & 45.72 & sand and trace gravel & $\begin{array}{l}\text { Medium-coarse gravelly sand, fewer large cobbles and } \\
\text { gravel, predominantly volcanic clasts. }\end{array}$ \\
\hline
\end{tabular}

Mark Group 312

Mark Group 312

48.77

51.82

sand and trace gravel

Mark Group 312

51.82

54.86

sand, clay and trace gravel

Mark Group 312

54.86

57.91

sand, clay and trace gravel

Mark Group 312

57.91

60.96

sand, clay and trace gravel

Mark Group 312

60.96

64.01

sand, clay and gravel

Mark Group 312

Mark Group 312

Mark Group 312

70.10

73.15

sand, clay and gravel

Mark Group 312

73.15

76.20

sand and gravel

Mark Group 312

76.20

79.25
Medium-coarse gravelly sand, angular to subangular grains, gravel $1 / 4-1 / 2$ in diameter, few gravel at $1 / 2$ in diameter (153 ft hole staying open better).

Medium-coarse gravelly sand, similar to $150 \mathrm{ft}$. Gravelly sand, brown, sand fine-medium some coarse, $\approx 30 \%$ gravel $1 / 4$ in diameter.

Gravelly silty sand, gravel $1 / 4-3 / 4$ in diameter $(\approx 10 \%)$, silt to silty clay $(\approx 20 \%), 170 \mathrm{ft}$ rig on cobble, hard drilling. At 177 cannot penetrate nearly as fast.

Gravelly silt clayey sand, less silt ( $\approx 5 \%), 10-15 \%$ gravel $1 / 4-1 / 2$ in diameter, sand predominantly mediumcoarse, well graded.

Gravelly silty clayey sand, 20-30\% silty clay, fine gravel $1 / 4-1 / 2$ in diameter, less clay. At $193 \mathrm{ft}$ hung tool on bottom.

Medium-coarse silty sand with some gravel, mostly sand (80\%), gravel $1 / 4-1 / 2$ in (5-10\%), clay (10-15\%).

Medium-coarse clayey sand, subangular to subrounded sand.

Fine to medium gravel sand, gravel $1 / 4-1 / 2$ in diameter, some clay present $(<5 \%)$, gravel $10-15 \%$.

Fine to medium-grained gravelly sand, medium gravel, no clay/silt present.

Fine to medium-grained gravelly sand, fine gravel $(<1 / 4$ in).

Fine-grained, some fine gravel $(<5 \%)$. 
Appendix 1. Compilation of borehole and aquifer data.-Continued

[cm, centimeter; $\mathrm{m}$, meter; in, inch; ft, feet; \%, percent; ppm, parts per million; $\approx$, approximately equal to; >, greater than]

\begin{tabular}{|c|c|c|c|c|}
\hline Bore & $\begin{array}{l}\text { Top } \\
\text { (m) }\end{array}$ & $\begin{array}{l}\text { Bottom } \\
(\mathrm{m})\end{array}$ & Simplified lithology & Driller's description \\
\hline Mark Group 312 & 79.25 & 82.30 & sand and trace gravel & $\begin{array}{l}\text { Fine to medium sand with some gravel }(<5 \%) \text {, mainly fine- } \\
\text { grained sand, brown. }\end{array}$ \\
\hline Mark Group 312 & 82.30 & 85.34 & sand and trace gravel & $\begin{array}{l}\text { Gravelly sand, well graded, sand fine-medium-grained, } \\
\text { gravel } 1 / 8-1 / 4 \text { in diameter }(\approx 20 \%) \text {, brown. }\end{array}$ \\
\hline Mark Group 312 & 85.34 & 87.17 & sand and trace gravel & $\begin{array}{l}\text { Static water level } 284.5 \mathrm{ft} \text { (corrected). Temporary Total } \\
\text { depth for water level measure, } 1.5 \mathrm{ft} \text { fill (blew hole, } \\
\approx 6 \text { in fill). }\end{array}$ \\
\hline Mark Group 312 & 87.17 & 88.39 & sand and trace gravel & $\begin{array}{l}\text { Started drilling } 286 \mathrm{ft} \text {. At } 290 \mathrm{ft} \text { gravelly sand well graded, } \\
\text { sand fine-medium mainly fine-grained, gravel } 1 / 8 \mathrm{in} \\
\text { diameter, angular-subangular. }\end{array}$ \\
\hline Mark Group 312 & 90.22 & 91.44 & sand and trace gravel & At $296 \mathrm{ft}$, (stopped to monitor water level). \\
\hline Mark Group 312 & 91.44 & 93.27 & sand and trace gravel & $\begin{array}{l}\text { Gravelly sand, brown (similar to } 290 \mathrm{ft} \text { ) Total depth drilled } \\
306 \mathrm{ft} \text {. }\end{array}$ \\
\hline Mark Group 312A & 0.00 & 3.05 & sand, clay and gravel & $\begin{array}{l}\text { slightly moist, medium dense, red brown, fine sand, some } \\
\text { silt, little gravel. }\end{array}$ \\
\hline Mark Group 312A & 3.05 & 6.10 & sand, clay and gravel & $\begin{array}{l}\text { slightly moist, medium dense, red brown, gravel, some } \\
\text { sand, little silt. }\end{array}$ \\
\hline Mark Group 312A & 18.29 & 23.77 & sand, clay and gravel & $\begin{array}{l}\text { Moist, medium dense, light red brown, mf gravel and cmf } \\
\text { sand, some silt. }\end{array}$ \\
\hline Mark Group 312A & 23.77 & 24.23 & sand, clay and gravel & Dense. \\
\hline Mark Group 312A & 24.23 & 24.69 & sand, clay and gravel & Dry, dense, brown, cmf gravel, little sand and silt. \\
\hline Mark Group 312A & 24.69 & 25.15 & sand, clay and gravel & Dry, dense, brown, mf gravel, some sand, little silt. \\
\hline Mark Group 312A & 25.15 & 30.48 & sand, clay and gravel & $\begin{array}{l}\text { slightly moist, dense, light brown, gravel, some sand, little } \\
\text { silt. }\end{array}$ \\
\hline Mark Group 312A & 30.48 & 30.94 & sand, clay and gravel & $\begin{array}{l}\text { Dry, dense, light brown, cmf gravel, some mf sand, little } \\
\text { silt. }\end{array}$ \\
\hline
\end{tabular}


Appendix 1. Compilation of borehole and aquifer data.-Continued

[cm, centimeter; $\mathrm{m}$, meter; in, inch; $\mathrm{ft}$, feet; $\%$, percent; ppm, parts per million; $\approx$, approximately equal to; >, greater than]

\begin{tabular}{|c|c|c|c|c|}
\hline Bore & $\begin{array}{l}\text { Top } \\
\text { (m) }\end{array}$ & $\begin{array}{l}\text { Bottom } \\
\text { (m) }\end{array}$ & Simplified lithology & Driller's description \\
\hline Mark Group 312A & 30.94 & 31.39 & sand, clay and gravel & $\begin{array}{l}\text { Dry, dense, light brown, cmf gravel, some mf sand, little } \\
\text { silt. }\end{array}$ \\
\hline Mark Group 312A & 31.39 & 36.58 & sand, clay and gravel & $\begin{array}{l}\text { slightly moist, medium dense, light brown, sand, some } \\
\text { gravel, little silt. }\end{array}$ \\
\hline Mark Group 312A & 36.58 & 39.62 & sand, clay and gravel & $\begin{array}{l}\text { slightly moist, medium dense, light brown, gravel, some } \\
\text { sand, little silt. }\end{array}$ \\
\hline Mark Group 312A & 39.62 & 48.16 & sand, clay and gravel & $\begin{array}{l}\text { slightly moist, medium dense, brown, gravel, some sand, } \\
\text { little silt. }\end{array}$ \\
\hline Mark Group 312A & 48.62 & 49.07 & sand, clay and gravel & Dense. \\
\hline Mark Group 312A & 49.07 & 54.86 & sand, clay and gravel & slightly moist, dense, brown, gravel, little sand and silt. \\
\hline Mark Group 312A & 54.86 & 60.96 & sand, clay and gravel & Wet, very dense, brown, gravel, little sand. \\
\hline Mark Group 312A & 60.96 & 61.42 & sand, clay and gravel & $\begin{array}{l}\text { Wet, dense, brown, mf gravel, some cmf sand, little silt and } \\
\text { clay. }\end{array}$ \\
\hline Mark Group 312A & 79.25 & 85.04 & sand and gravel & Wet, medium dense, brown, cmf gravel, some cmf sand. \\
\hline Mark Group 312A & 85.04 & 85.50 & sand and gravel & Wet, medium dense, brown, cmf sand, come cmf gravel. \\
\hline Mark Group 312A & 85.50 & 91.44 & sand and gravel & Wet, medium dense, brown, cmf sand, come cmf gravel. \\
\hline Mark Group 312A & 91.44 & 91.90 & sand, clay and gravel & $\begin{array}{l}\text { Wet, medium dense, brown, silt and sand, little clay and } \\
\text { gravel. }\end{array}$ \\
\hline Mark Group 313 & 0.00 & 3.05 & sand and trace gravel & $\begin{array}{l}\text { Installing } 40 \mathrm{ft} \text { of surface casing ( } 121 / 4 \text { in diameter). } \\
\text { Drilling depth from land surface. Elevation/Measuring } \\
\text { point will be top of casing. Height of casing above land } \\
\text { surface is } 1.64 \mathrm{ft} \text {. }\end{array}$ \\
\hline
\end{tabular}


Appendix 1. Compilation of borehole and aquifer data.-Continued

[cm, centimeter; $\mathrm{m}$, meter; in, inch; ft, feet; \%, percent; ppm, parts per million; $\approx$, approximately equal to; >, greater than]

\begin{tabular}{|c|c|c|c|c|}
\hline Bore & $\begin{array}{l}\text { Top } \\
\text { (m) }\end{array}$ & $\begin{array}{l}\text { Bottom } \\
\text { (m) }\end{array}$ & Simplified lithology & Driller's description \\
\hline Mark Group 313 & 3.05 & 9.14 & sand and gravel & $\begin{array}{l}\text { At } 10 \mathrm{ft} \text {, medium to fine-grained sandy gravel, } 10-15 \% \\
\text { coarse gravel, } 1 \text { in diameter, brown. }\end{array}$ \\
\hline Mark Group 313 & 9.14 & 15.24 & sand and trace gravel & $\begin{array}{l}\text { At } 30 \mathrm{ft} \text {, fine-medium-grained sand, very little gravel, } \\
\text { probably remnants in discharge line. At } 35 \mathrm{ft} \text { (secure } \\
\text { surface casing). }\end{array}$ \\
\hline Mark Group 313 & 15.24 & 18.29 & sand and gravel & $\begin{array}{l}\text { Fine to coarse-grained sand, no gravel, coarse grains } \\
\quad \approx 1 / 8 \text { in }(\approx 10 \%) .\end{array}$ \\
\hline Mark Group 313 & 18.29 & 24.38 & sand and gravel & $\begin{array}{l}\text { Very fine to coarse sandy gravel, } 30 \% \text { gravel } \approx 1 / 2 \text { in, } \\
1 / 4 \text { in diameter. }\end{array}$ \\
\hline Mark Group 313 & 27.43 & 30.48 & sand and gravel & $\begin{array}{l}\text { Brownish fine-medium-grained sandy gravel, gravel } 3 / 4 \text { in } \\
\text { diameter } 10 \%, 1 / 2 \text { in diameter } 30 \% \text {. Subangular, some } \\
\text { subrounded. }\end{array}$ \\
\hline Mark Group 313 & 30.48 & 33.53 & sand and gravel & $\begin{array}{l}\text { Brownish fine-medium-grained, sandy gravel, gravel } \\
>3 / 4 \text { in diameter } 15 \% \text {. }\end{array}$ \\
\hline Mark Group 313 & 33.53 & 36.58 & sand and gravel & $\begin{array}{l}\text { Brownish black, medium to fine sandy gravel, gravel avg. } \\
\quad<1 / 2 \text { in diameter, very fine sand and some clay present. }\end{array}$ \\
\hline Mark Group 313 & 42.67 & 45.72 & sand and gravel & $\begin{array}{l}\text { Medium-grained gravelly sand, brownish, no clay present, } \\
\text { similar to above. At } 143 \text { (hammer/heard jamming on } \\
\text { drill pipe) (After letting hole sit } 1 \text { day, } \approx 3 \mathrm{ft} \text { of fill in bot- } \\
\text { tom. Top at } 138 \mathrm{ft} \text { ). }\end{array}$ \\
\hline Mark Group 313 & 45.72 & 48.77 & sand and gravel & $\begin{array}{l}\text { Brownish-red gravelly sand, sand medium to fine-grained, } \\
\text { subangular, gravel medium-grained } \approx 1 / 2 \text { in diameter } \\
10 \% \text {. }\end{array}$ \\
\hline Mark Group 313 & 48.77 & 51.82 & sand and gravel & $\begin{array}{l}\text { Brownish-black (volcanic) gravelly sand, sand medium to } \\
\text { fine-grained, subangular, some gravel } \approx 1 / 2 \text { in diameter, } \\
\text { largest percent gravel } 1 / 81 / 4 \text { in diameter, total gravel } \\
5 \% \text {. }\end{array}$ \\
\hline Mark Group 313 & 51.82 & 54.86 & sand and gravel & $\begin{array}{l}\text { Brownish-red sandy gravel, gravel, } 1 / 4-1 / 2 \text { in diameter, } \\
\text { well graded, sand fine to medium-grained. }\end{array}$ \\
\hline
\end{tabular}


Appendix 1. Compilation of borehole and aquifer data.-Continued

[cm, centimeter; $\mathrm{m}$, meter; in, inch; ft, feet; \%, percent; ppm, parts per million; $\approx$, approximately equal to; >, greater than]

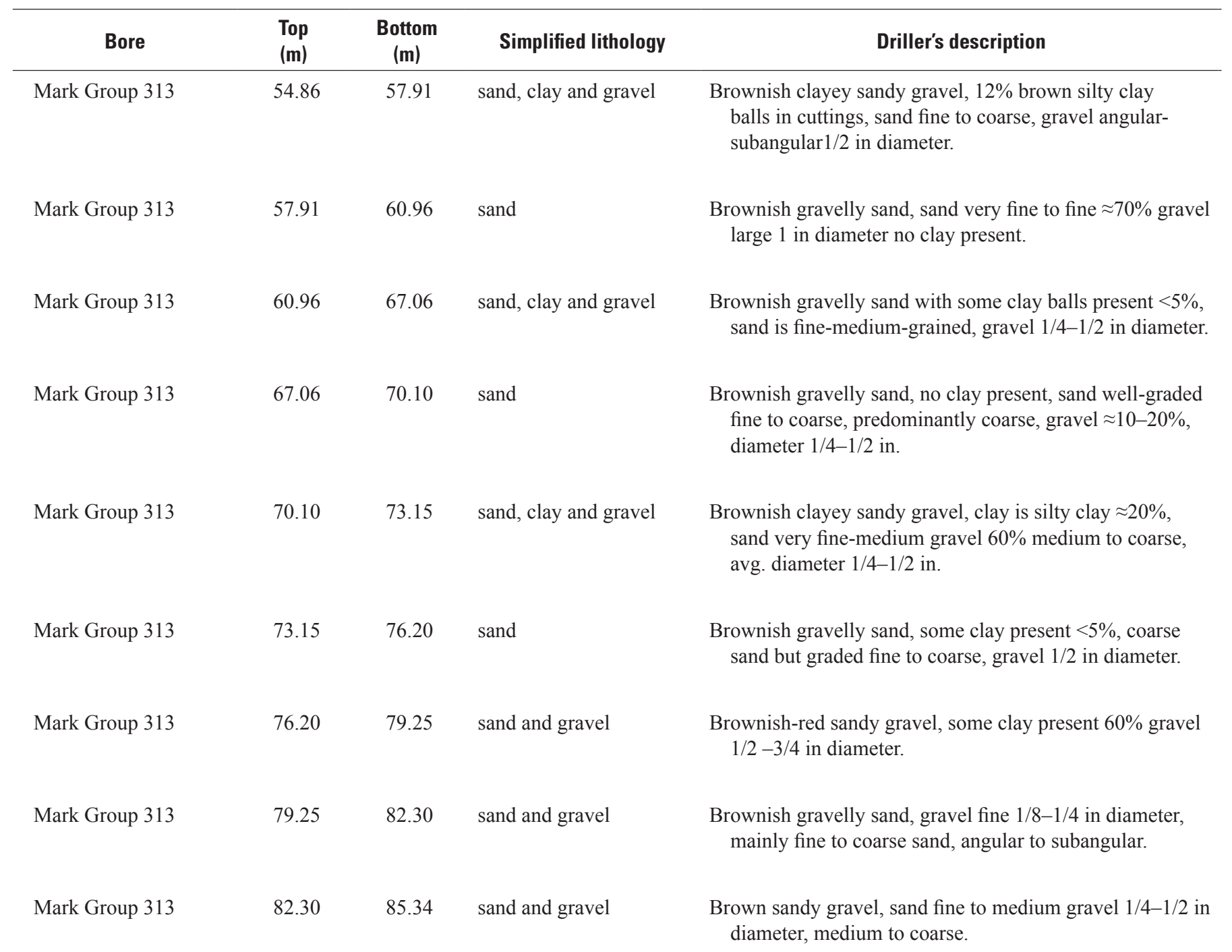

Mark Group 313

Mark Group 313

88.39

91.44

sand, clay and gravel

Mark Group 313
$85.34 \quad 88.39 \quad$ sand, clay and gravel
Static water level at $287.20 \mathrm{ft}$. At $290 \mathrm{ft}$ brownish clayey gravelly sand, sand medium to coarse-grained, angular to subangular, gravel fine to medium-grained, $1 / 8$ in diameter, clayey is silty clay, $\approx 10-20 \%$.

Brownish gravelly clayey sand, clay is silty clay $\approx 30 \%$, gravel medium-grained $1 / 2$ in diameter $10 \%$, sand wellgraded fine to coarse $60 \%$, fine-grained sand bound in clay. Depth of hole $303.2 \mathrm{ft}$.

At $307 \mathrm{ft}$ 8/23/88 drill to Total depth. 
Appendix 1. Compilation of borehole and aquifer data.-Continued

[cm, centimeter; $\mathrm{m}$, meter; in, inch; $\mathrm{ft}$, feet; \%, percent; ppm, parts per million; $\approx$, approximately equal to; >, greater than]

\begin{tabular}{ccccc}
\hline Bore & $\begin{array}{c}\text { Top } \\
\text { (m) }\end{array}$ & $\begin{array}{c}\text { Bottom } \\
(\mathbf{m})\end{array}$ & Simplified lithology & Driller's description \\
\hline Mark Group 313 & 94.49 & 97.54 & sand, clay and gravel & $\begin{array}{c}\text { Brownish sandy clayey gravel, sand very fine-fine bound in } \\
\text { the clay } \approx 10 \% \text {, clayey material is gritty with very fine- } \\
\text { grained sand and silt } 40 \% \text { gravel is } 1 / 2 \text { in diameter. At }\end{array}$ \\
& & & $\begin{array}{l}320 \mathrm{ft} \text { reddish brownish medium to coarse-grained sand, } \\
\text { few clay ball present probably residual. Total Depth } \\
\text { drilled } 320 \mathrm{ft} .\end{array}$
\end{tabular}

Mark Group 314

Mark Group 314

Mark Group 314

Mark Group 314

Mark Group 314

Mark Group 314

Mark Group 314

Mark Group 314

33.53

36.58

sand, clay and gravel

Mark Group 314

36.58

39.62

sand, clay and gravel

\section{Mark Group 314}

39.62

42.67

sand and clay

Mark Group 314

14.63 sand, clay and gravel

18.29 sand and gravel

sand and gravel

sand and gravel

sand and gravel

sand and gravel

sand and clay
Brown, fine to medium-grained sand with some clay present, no gravel observed. At $106 \mathrm{ft}$ rig down trying to get foam to dissipate.

Brown, gravelly sand, well graded, sand very fine to medium-grained, gravel $1 / 8-1 / 2$ in diameter, mainly $1 / 2$ in diameter, some clay present.

Brownish red, sandy gravel with some clay, well graded, sand is very fine to medium-grained, gravel fine to coarse, $1 / 8-3 / 4$ in diameter, mainly $1 / 4$ in diameter.

Brownish red, gravelly sand with some clay, sand is very fine to medium-grained, gravel medium-grained.

Brown sand with gravel and some clay, well graded, sand very fine to medium-grained, gravel is fine to medium $1 / 8-1 / 4$ in diameter. 
Appendix 1. Compilation of borehole and aquifer data.-Continued

[cm, centimeter; $\mathrm{m}$, meter; in, inch; ft, feet; \%, percent; ppm, parts per million; $\approx$, approximately equal to; >, greater than]

\begin{tabular}{|c|c|c|c|c|}
\hline Bore & $\begin{array}{l}\text { Top } \\
(\mathrm{m})\end{array}$ & $\begin{array}{l}\text { Bottom } \\
(\mathrm{m})\end{array}$ & Simplified lithology & Driller's description \\
\hline Mark Group 314 & 45.72 & 48.77 & sand, clay and gravel & $\begin{array}{l}\text { Brown, very sand gravel with some clay, well graded, sand } \\
\text { very fine to medium gravel fine to medium } 1 / 8-1 / 4 \text { in } \\
\text { diameter, mainly } 1 / 4 \text { in diameter. }\end{array}$ \\
\hline Mark Group 314 & 48.77 & 51.82 & sand and gravel & $\begin{array}{l}\text { Brown sand with some fine gravel, sand well graded, very } \\
\text { fine to medium-grained. }\end{array}$ \\
\hline Mark Group 314 & 51.82 & 54.86 & sand, clay and gravel & $\begin{array}{l}\text { Brown, clayey sandy gravel, well graded, sand very fine to } \\
\text { fine-grained, gravel fine to coarse, } 1 / 16-1 / 2 \text { in diameter. }\end{array}$ \\
\hline Mark Group 314 & 54.86 & 57.91 & sand, clay and gravel & $\begin{array}{l}\text { Brown, clayey sandy gravel, well graded, sand very fine to } \\
\text { fine-grained, gravel fine to coarse, } 1 / 16-1 / 2 \text { in diameter. }\end{array}$ \\
\hline Mark Group 314 & 60.96 & 64.01 & sand, clay and gravel & $\begin{array}{l}\text { Brown, silty-sandy gravel, well graded, angular to suban- } \\
\text { gular, gravel clasts } \leq 1 / 2 \text { in diameter. }\end{array}$ \\
\hline Mark Group 314 & 64.01 & 67.06 & sand and gravel & $\begin{array}{l}\text { Brown, gravelly sand, well graded, angular to subrounded, } \\
\text { gravel clasts } \leq 1 / 4 \text { in diameter. }\end{array}$ \\
\hline Mark Group 314 & 67.06 & 70.10 & sand and gravel & Same as above with gravel clasts $\leq 1 / 2$ in diameter. \\
\hline Mark Group 314 & 76.20 & 79.25 & sand and gravel & $\begin{array}{l}\text { Brown, coarse-grained sand with minor gravel, well } \\
\text { graded. }\end{array}$ \\
\hline Mark Group 314 & 79.25 & 82.30 & sand and gravel & Same as above. \\
\hline Mark Group 314 & 82.30 & 85.34 & sand, clay and gravel & Brown silty sand, well graded, coarse to fine-grained. \\
\hline Mark Group 314 & 85.34 & 88.39 & sand, clay and gravel & $\begin{array}{l}\text { Light brown, silty sand, well graded, coarse to fine- } \\
\text { grained, subangular to subrounded. }\end{array}$ \\
\hline Mark Group 314 & 88.39 & 91.44 & sand and clay & $\begin{array}{l}\text { Silty sand, light brown, well graded, coarse to fine-grained, } \\
\text { subangular to subrounded. }\end{array}$ \\
\hline Mark Group 314 & 91.44 & 94.49 & sand and clay & Same as above. Static water level at $302.29 \mathrm{ft}$. \\
\hline
\end{tabular}


Appendix 1. Compilation of borehole and aquifer data.-Continued

[cm, centimeter; $\mathrm{m}$, meter; in, inch; ft, feet; \%, percent; ppm, parts per million; $\approx$, approximately equal to; >, greater than]

\begin{tabular}{|c|c|c|c|c|}
\hline Bore & $\begin{array}{l}\text { Top } \\
(\mathrm{m})\end{array}$ & $\begin{array}{l}\text { Bottom } \\
\text { (m) }\end{array}$ & Simplified lithology & Driller's description \\
\hline Mark Group 314 & 94.49 & 97.54 & sand, clay and gravel & $\begin{array}{l}\text { Brown, silt, very fine sand with some gravel, well graded, } \\
\text { sand is very fine to coarse-grained, gravel is fine to } \\
\text { medium-grained. }\end{array}$ \\
\hline Mark Group 314 & 97.54 & 100.58 & sand, clay and gravel & $\begin{array}{l}\text { Circulating foam. Similar to above interval. At } 326 \mathrm{ft} \\
\text { stopped circulating. }\end{array}$ \\
\hline Mark Group 314 & 100.58 & 102.41 & sand, clay and gravel & $\begin{array}{l}\text { Brown, silty sand with some gravel, well graded, sand very } \\
\text { fine to coarse-grained, gravel fine to medium-grained. } \\
\text { Total depth drilled } 336 \mathrm{ft} \text {. }\end{array}$ \\
\hline Mark Group 315 & 3.05 & 6.10 & sand and gravel & $\begin{array}{l}\text { Brownish red, well graded gravel, very little fines, wash- } \\
\text { ing out with fines, gravel diameter } 3 / 4-1 \text { in, angular to } \\
\text { subangular. }\end{array}$ \\
\hline Mark Group 315 & 6.10 & 9.14 & sand and trace gravel & $\begin{array}{l}\text { Reddish brown, gravelly sand, well graded, fine-medium- } \\
\text { grained subangular sand, gravel } \approx 1 / 2 \text { in diameter well } \\
\text { graded. }\end{array}$ \\
\hline Mark Group 315 & 12.19 & 18.29 & sand and gravel & $\begin{array}{l}\text { Reddish brown sandy gravel, well graded, sand medium to } \\
\text { fine-grained, gravel }(\approx 20 \%) 1 / 8-1 / 4 \text { in diameter. }\end{array}$ \\
\hline Mark Group 315 & 18.29 & 21.34 & sand and trace gravel & $\begin{array}{l}\text { Brown well graded sand with some gravel, sand very fine- } \\
\text { medium-grained, mainly fine-grained, gravel }(<10 \%) \\
\text { medium-grained } 1 / 8 \text { in diameter. }\end{array}$ \\
\hline Mark Group 315 & 21.34 & 24.38 & sand and trace gravel & $\begin{array}{l}\text { Reddish brown gravelly sand, sand well graded fine-medi- } \\
\text { um-grained, gravel } \approx 1 / 4 \text { in diameter }(20 \%) \text {. }\end{array}$ \\
\hline Mark Group 315 & 24.38 & 27.43 & sand and trace gravel & $\begin{array}{l}\text { Brownish medium to fine sand with very little gravel, } \\
\text { predominant grain size fine sand }(\approx 60 \%) \text {. At } 86 \mathrm{ft} \text { (hole } \\
\text { staying open, not caving when adding drill pipe). }\end{array}$ \\
\hline
\end{tabular}


Appendix 1. Compilation of borehole and aquifer data.-Continued

[cm, centimeter; $\mathrm{m}$, meter; in, inch; ft, feet; \%, percent; ppm, parts per million; $\approx$, approximately equal to; >, greater than]

\begin{tabular}{ccccc}
\hline Bore & $\begin{array}{c}\text { Top } \\
(\mathbf{m})\end{array}$ & $\begin{array}{c}\text { Bottom } \\
(\mathbf{m})\end{array}$ & Simplified lithology & Driller's description \\
\hline Mark Group 315 & 27.43 & 30.48 & sand and trace gravel & $\begin{array}{c}\text { Brownish, medium to fine sand with some gravel, and } \\
\text { medium to fine, well graded, predominantly fine, gravel } \\
1 / 4 \text { in diameter }(<10 \%) .\end{array}$
\end{tabular}

Mark Group $315 \quad 30.48 \quad 33.53 \quad$ sand, clay and grave

Mark Group $315 \quad 33.53 \quad 36.58 \quad$ sand and trace gravel

Mark Group 315

36.58

39.62

sand, clay and gravel

Mark Group 315

Mark Group 315

42.67

45.72

sand, clay and trace gravel

Mark Group 315

45.72

48.77

sand, clay and gravel

Mark Group 315

48.77

51.82

sand, clay and gravel

Mark Group 315

51.82

54.86

sand and gravel

Mark Group 315

54.86

57.91

sand, clay and gravel

Mark Group 315

57.91

60.96

sand and trace gravel

Mark Group 315

60.96

64.01

sand, clay and gravel

64.01

67.06

sand
Brownish very-fine sand with silty gravel, gravel $1 / 2-3 / 4$ in diameter, mainly $1 / 2$ in diameter $(\approx 20 \%)$, some silty/clay balls present.

Reddish brown fine-medium sand with some gravel $1 / 2-1$ in diameter $(\approx 10 \%)$.

Reddish brown very fine-medium clayey sand with gravel, clay balls are silty with sand, very fine-grained gravel $(\approx 10-20 \%) 1 / 2$ in diameter.

Reddish brown fine to coarse sand with some gravel, gravel 1/8-1/4 in diameter, some clay present.

Brownish sand, some clay present, little gravel, sand well graded very fine-medium mainly fine-grained, gravel fine $<1 / 8$ in diameter $(<10 \%)$.

Grayish brown silty gravel with some sand, gravel 1/8 in diameter, silty material gritty with very fine sand rolled into balls.

Grayish brown clayey gravel with some sand, gravel well graded $1 / 8-1 / 2$ in diameter, clay is silty clay with fine sand rolled into balls.

Reddish brown sandy gravel, well graded, sand fine-medium no clay, gravel $1 / 8-1 / 2$ in diameter, predominantly $1 / 2$ in.

Brownish sand clayey gravel, well graded sand, very fine to medium clay is silty clay with sand rolled into balls, gravel $1 / 8-1 / 2$ in diameter $(50 \%)$.

Reddish brown gravelly sand, well graded, sand angular to subangular, fine-medium-grained, gravel $1 / 8-1 / 4$ in diameter $(\approx 15 \%)$, little clay present.

Brownish sandy clayey gravel, well graded, sand very finemedium gravel $1 / 8-1 / 2$ in, $1 / 4$ in predominant.

Brownish medium-coarse sand, angular to subangular, (lots of rig chatter, grinding up cobbles) no clay. 
Appendix 1. Compilation of borehole and aquifer data.-Continued

[cm, centimeter; $\mathrm{m}$, meter; in, inch; $\mathrm{ft}$, feet; \%, percent; ppm, parts per million; $\approx$, approximately equal to; >, greater than]

\begin{tabular}{|c|c|c|c|c|}
\hline Bore & $\begin{array}{l}\text { Top } \\
\text { (m) }\end{array}$ & $\begin{array}{l}\text { Bottom } \\
(\mathrm{m})\end{array}$ & Simplified lithology & Driller's description \\
\hline Mark Group 315 & 67.06 & 70.10 & sand, clay and gravel & $\begin{array}{l}\text { Brownish sandy gravel with some clay, well graded, sand } \\
\text { fine-medium clay-reddish very little silt }(<10 \%) \text {, gravel } \\
\text { medium-coarse } 1 / 8-2 / 4 \text { in diameter. }\end{array}$ \\
\hline Mark Group 315 & 70.10 & 73.15 & sand, clay and gravel & $\begin{array}{l}\text { Reddish brown sandy gravel with some clay, sand medium- } \\
\text { grained, gravel angular } 1 / 8-3 / 4 \text { in diameter, clay }<5 \% \text {. }\end{array}$ \\
\hline Mark Group 315 & 73.15 & 76.20 & sand and clay & $\begin{array}{l}\text { Brownish gravelly sand with some clay, sand very fine- } \\
\text { medium-grained, } 60 \% \text { fine-grained, gravel } 1 / 8-1 / 4 \text { in } \\
\text { diameter, some clay }(<5 \%) \text {. }\end{array}$ \\
\hline Mark Group 315 & 79.25 & 82.30 & sand and trace gravel & $\begin{array}{l}\text { Brownish sand with trace gravel, sand very fine-medium } \\
\text { grain, predominantly fine-grained, }<10 \% \text { fine gravel } \\
\approx 1 / 8 \text { in diameter. }\end{array}$ \\
\hline Mark Group 315 & 82.30 & 85.34 & sand, clay and gravel & $\begin{array}{l}\text { Brownish sand with trace gravel, sand fine to coarse, } \\
\text { mainly medium-grained, no trace of clay-silt. }\end{array}$ \\
\hline Mark Group 315 & 85.34 & 88.39 & sand and trace gravel & $\begin{array}{l}\text { Brownish sand with trace gravel, sand fine to coarse, } \\
\text { mainly medium }(60 \%) \text {, gravel } 1 / 8 \text { in diameter. }\end{array}$ \\
\hline Mark Group 315 & 94.49 & 97.84 & sand, clay and gravel & $\begin{array}{l}\text { No return } 0707 \text { foam at surface. brown gravelly sand with } \\
\text { some clay, sand fine to coarse, mainly medium-grained, } \\
\text { gravel 1/8-1/4 in diameter (10-20\%), clay-silty clay } \\
<5 \% \text {. }\end{array}$ \\
\hline Mark Group 315 & 97.84 & 100.58 & sand, clay and gravel & $\begin{array}{l}\text { At } 320 \mathrm{ft} \text {, brown gravelly sand with some clay, sand fine to } \\
\text { coarse, mainly medium-grained, gravel } 1 / 8-1 / 4 \text { in diam- } \\
\text { eter }(10-20 \%) \text {, clay is silty clay }(<5 \%) \text {, similar to } 310 \mathrm{ft} \text {. } \\
321.5 \mathrm{ft} \text {, depth of hole, bottom of screen. }\end{array}$ \\
\hline
\end{tabular}


Appendix 1. Compilation of borehole and aquifer data.-Continued

[cm, centimeter; $\mathrm{m}$, meter; in, inch; ft, feet; \%, percent; ppm, parts per million; $\approx$, approximately equal to; >, greater than]

\begin{tabular}{ccccc}
\hline Bore & $\begin{array}{c}\text { Top } \\
(\mathbf{m})\end{array}$ & $\begin{array}{c}\text { Bottom } \\
(\mathbf{m})\end{array}$ & Simplified lithology & Driller's description \\
\hline Mark Group 315 & 100.58 & 103.63 & $\begin{array}{c}\text { clay, sand and trace } \\
\text { gravel }\end{array}$ & $\begin{array}{c}\text { At } 330 \mathrm{ft} \text {, light grayish brown sandy silt with some gravel, } \\
\text { sand well graded fine to medium-grained, gravel }<10 \%\end{array}$ \\
& & & $1 / 8-1 / 4$ in diameter, silt is strongly cemented and is very \\
& & & hard drilling. At 340 ft, Gray brown sandy silt, sand is \\
fine to medium-grained, mainly fine-grained, strongly \\
cemented, similar to 330 ft, total depth drilled 340 ft.
\end{tabular}

Mark Group 316

Mark Group 316

Mark Group 316

Mark Group 316

Mark Group 316

Mark Group 316

Mark Group 316

Mark Group 316

Mark Group 316

Mark Group 316

Mark Group 316

Mark Group 316
0.00

12.19

12.19

15.24

18.29

21.34

sand and gravel

$21.34 \quad 24.38 \quad$ sand and gravel

$24.38 \quad 27.43 \quad$ sand and gravel

$27.43 \quad 33.53 \quad$ sand and gravel

$33.53 \quad 36.58 \quad$ sand and trace gravel

36.58

39.62

sand and trace gravel

$39.62 \quad 45.72 \quad$ sand, clay and gravel

45.72

48.77

sand and trace gravel

$48.77 \quad 51.82 \quad$ sand, clay and gravel
No data. $40 \mathrm{ft}$ of surface casing previously installed (121/4 in diameter). Elevation/Measuring point is top of casing. Height of measuring point above land surface is $0.86 \mathrm{ft}$.

(42.41 to $50 \mathrm{ft}$ ) Coarse sand with gravel, well graded, reddish brown, some cobbles, rounded to subrounded.

Medium to coarse sand with $10 \%$ gravel, no cobbles, moderately graded.

Sandy gravel with $2 \%$ cobbles, well rounded to subrounded, well graded.

Fine to coarse sandy gravel with $15 \%$ cobbles well rounded, well graded.

Fine to coarse sand with 5\% gravel, well graded, reddishbrown.

Sandy gravel with small cobbles, well graded, well rounded gravel and cobbles, reddish brown. At $108 \mathrm{ft}$ (ran out of water, fill truck).

Medium to coarse sand with $15 \%$ gravel, subrounded to subangular, well graded, brown.

Medium to coarse sand with $10 \%$ gravel, subrounded to subangular, well graded, brown.

Sandy gravel with minor silt, subrounded to subangular, well graded, brown, rig chatter.

Gravelly sand, subrounded to subangular, well graded, brown.

Sandy gravel with balled clay, well graded, subrounded to subangular, brown. At $168 \mathrm{ft}$ (smooth drilling). 
Appendix 1. Compilation of borehole and aquifer data.-Continued

[cm, centimeter; $\mathrm{m}$, meter; in, inch; ft, feet; \%, percent; ppm, parts per million; $\approx$, approximately equal to; >, greater than]

\begin{tabular}{|c|c|c|c|c|}
\hline Bore & $\begin{array}{l}\text { Top } \\
\text { (m) }\end{array}$ & $\begin{array}{l}\text { Bottom } \\
\text { (m) }\end{array}$ & Simplified lithology & Driller's description \\
\hline Mark Group 316 & 51.82 & 58.52 & sand and trace gravel & $\begin{array}{l}\text { Medium to coarse gravelly sand, moderately graded, } \\
\text { subrounded to subangular, brown. At } 184 \mathrm{ft} \text { ( } 2140 \text { start } \\
\text { drilling again). At } 186 \mathrm{ft} \text { same as above. }\end{array}$ \\
\hline Mark Group 316 & 58.52 & 62.18 & sand, clay and gravel & $\begin{array}{l}\text { Gravelly sand with silt and minor clay, subrounded to sub- } \\
\text { angular, well graded, brown. Rig chatter } 188-193 \mathrm{ft} \text {. }\end{array}$ \\
\hline Mark Group 316 & 62.18 & 64.77 & sand and trace gravel & $\begin{array}{l}\text { Gravelly sand, moderately graded, subrounded to subangu- } \\
\text { lar, brown. }\end{array}$ \\
\hline Mark Group 316 & 64.77 & 70.71 & sand, clay and gravel & $\begin{array}{l}\text { Sandy gravel, well graded, subrounded to subangular, } \\
\text { brown. At } 228 \mathrm{ft} \text { same as above with minor silt. Rig } \\
\text { chatter at } 231 \mathrm{ft} \text {. }\end{array}$ \\
\hline Mark Group 316 & 70.71 & 76.81 & sand and trace gravel & $\begin{array}{l}\text { Gravelly sand, well graded, subrounded to subangular, } \\
\text { brown. At } 240 \mathrm{ft} \text { same as above. At } 246 \mathrm{ft} \text { smooth drill- } \\
\text { ing, slow. }\end{array}$ \\
\hline Mark Group 316 & 76.81 & 79.86 & $\begin{array}{l}\text { sand, clay and trace } \\
\text { gravel }\end{array}$ & Silty sand with $10 \%$ gravel, minor clay, brown. \\
\hline Mark Group 316 & 79.86 & 83.06 & $\begin{array}{l}\text { sand, clay and trace } \\
\text { gravel }\end{array}$ & Silty sand, increasing silt, $5 \%$ gravel, minor clay, brown. \\
\hline Mark Group 316 & 88.39 & 94.49 & clay and sand & $\begin{array}{l}\text { Sandy silt, brown, plastic. At } 296.5 \mathrm{ft} \text { sandy gravelly silt, } \\
\text { brown, plastic, rig chatter. At } 302 \mathrm{ft} \text { clayey silt, brown, } \\
\text { plastic (smooth drilling) Total depth drilled } 310 \mathrm{ft} \text {. }\end{array}$ \\
\hline Mark Group 317 & 0.00 & 3.05 & clay and sand & $\begin{array}{l}\text { No data. Installing } 40 \mathrm{ft} \text { of surface casing ( } 121 / 4 \text { in } \\
\text { diameter) Drilling depths from land surface. Measuring } \\
\text { point will be top of casing. Height of casing above land } \\
\text { surface is } 1.65 \mathrm{ft} \text {. }\end{array}$ \\
\hline Mark Group 317 & 3.05 & 6.10 & sand and gravel & $\begin{array}{l}\text { Light brown, sandy gravel, well graded, sand fine to } \\
\text { coarse-grained, gravel } 1 / 2-1 \text { in diameter. }\end{array}$ \\
\hline Mark Group 317 & 6.10 & 9.14 & sand and gravel & $\begin{array}{l}\text { Light brown, sandy gravel, well graded (similar to above } \\
\text { sample) } 22 \mathrm{ft} \text {, installing second section of } 12 \text { in casing. }\end{array}$ \\
\hline
\end{tabular}


Appendix 1. Compilation of borehole and aquifer data.-Continued

[cm, centimeter; $\mathrm{m}$, meter; in, inch; ft, feet; \%, percent; ppm, parts per million; $\approx$, approximately equal to; >, greater than]

\begin{tabular}{ccccc}
\hline Bore & $\begin{array}{c}\text { Top } \\
(\mathbf{m})\end{array}$ & $\begin{array}{c}\text { Bottom } \\
(\mathbf{m})\end{array}$ & Simplified lithology & Driller's description \\
\hline Mark Group 317 & 9.14 & 15.24 & sand and gravel & $\begin{array}{c}\text { Brown, gravelly sand, well graded, sand fine to coarse- } \\
\text { grained, subangular to subrounded, gravel medium to } \\
\text { coarse-grained, } 1 / 8-3 / 4 \text { in diameter. }\end{array}$
\end{tabular}

Mark Group 317

Mark Group 317

Mark Group 317

Mark Group 317

Mark Group 317

Mark Group 317

Mark Group 317

Mark Group 317

Mark Group 317

Mark Group 317

Mark Group 317

Mark Group 317
15.24

18.29

sand, clay and gravel

18.29

sand and gravel

$21.34 \quad 24.38 \quad$ sand and gravel

24.38

27.43

sand, clay and gravel

$27.43 \quad 30.48 \quad$ sand, clay and gravel

$30.48 \quad 33.53 \quad$ sand, clay and gravel

$33.53 \quad 36.58 \quad$ sand and gravel

$36.58 \quad 39.62 \quad$ sand and gravel

39.62

42.67

sand, clay and gravel

42.67

45.72 sand, clay and gravel

45.72

48.77 sand, clay and gravel

48.77
Brown gravelly sand, well graded, sand fine to coarsegrained, gravel fine to coarse-grained.

Brown sand with gravel, well graded, sand fine to coarsegrained (mainly coarse-grained), gravel fine to coarsegrained, 1/8-1/2 diameter.

Brown, sandy gravel, sand fine to medium-grained, gravel fine to coarse, mainly medium-grained $1 / 4$ in diameter.

Brown, gravelly sand with some silt, sand fine to coarsegrained, gravel fine to coarse-grained, $1 / 8-1 / 2$ in diameter.

Brown, gravelly sand with some silt, sand very fine to coarse-grained (mainly fine-grained), gravel fine to coarse, mainly medium-grained, $1 / 8-1 / 2$ in diameter, some 1 in diameter.

Brown, gravelly sand with some silt, sand well graded, fine to coarse-grained, gravel fine to coarse-grained (mainly medium).

Brown, gravelly sand, well graded, sand very fine to coarse-grained (mainly medium-grained) gravel fine to medium-grained, $\approx 1$ in diameter.

Brown, gravelly sand, well graded, same as above interval except gravel medium-grained, $1 / 4$ in diameter.

Brown, sand with some silt and gravel, well graded, sand very fine to coarse-grained, gravel fine to medium $1 / 8-1 / 4$ in diameter.

Brown, gravelly sand with some silt, well graded, sand very fine to coarse, gravel medium-grained, $1 / 8-1 / 2$ in diameter.

Brown, gravelly sand with some silt.

Brown, sandy gravel with some silt, well graded, sand very fine to coarse-grained (mainly medium-grained), gravel fine to medium-grained, 1/16-1/4 in diameter. 
Appendix 1. Compilation of borehole and aquifer data.-Continued

[cm, centimeter; $\mathrm{m}$, meter; in, inch; $\mathrm{ft}$, feet; \%, percent; ppm, parts per million; $\approx$, approximately equal to; >, greater than]

\begin{tabular}{|c|c|c|c|c|}
\hline Bore & $\begin{array}{l}\text { Top } \\
\text { (m) }\end{array}$ & $\begin{array}{l}\text { Bottom } \\
\text { (m) }\end{array}$ & Simplified lithology & Driller's description \\
\hline Mark Group 317 & 51.82 & 54.86 & sand, clay and gravel & $\begin{array}{l}\text { Brown, silty sand with gravel, well graded, sand very fine } \\
\text { to coarse-grained, gravel fine to coarse (mainly medium- } \\
\text { grained), } 1 / 8-1 / 4 \text { in diameter. }\end{array}$ \\
\hline Mark Group 317 & 54.86 & 57.91 & sand, clay and gravel & Same as previous interval. \\
\hline Mark Group 317 & 57.91 & 60.96 & sand, clay and gravel & $\begin{array}{l}\text { Brown, gravelly sand with some silt, well graded, sand } \\
\text { very fine to coarse, mainly fine sand, gravel fine to } \\
\text { medium-grained. }\end{array}$ \\
\hline Mark Group 317 & 60.96 & 64.01 & sand, clay and gravel & $\begin{array}{l}\text { Brown, gravelly sand with some silt, sand fine to medium- } \\
\text { grained, gravel fine to medium-grained, } 1 / 16-1 / 4 \text { in } \\
\text { diameter. }\end{array}$ \\
\hline Mark Group 317 & 64.01 & 67.06 & sand, clay and gravel & $\begin{array}{l}\text { Same as previous interval except fine to coarse-grained, } \\
\text { cuttings } 1 / 8-1 / 2 \text { in diameter. }\end{array}$ \\
\hline Mark Group 317 & 67.06 & 70.10 & sand, clay and gravel & $\begin{array}{l}\text { Hnu readings, } 37 \mathrm{ppm} \text { inside casing, } 0.0 \mathrm{ppm} \text { work zone, } \\
22 \mathrm{ppm} \text { inside drill pipe. }\end{array}$ \\
\hline Mark Group 317 & 70.10 & 73.15 & sand and clay & Brown sand with trace of silt, fine to medium-grained. \\
\hline Mark Group 317 & 73.15 & 76.20 & sand, clay and gravel & $\begin{array}{l}\text { Brown, silty sand with gravel, sand medium to very fine- } \\
\text { grained, gravel fine to medium } 1 / 16-1 / 4 \text { in diameter. }\end{array}$ \\
\hline Mark Group 317 & 82.30 & 85.34 & sand and gravel & $\begin{array}{l}\text { Brown, sandy gravel, well graded, gravel fine to medium- } \\
\text { grained, } 1 / 8-1 / 2 \text { in diameter, sand fine to coarse-grained. }\end{array}$ \\
\hline Mark Group 317 & 85.34 & 88.39 & sand and gravel & $\begin{array}{l}\text { Brownish-red, sand with gravel, sand very fine to coarse- } \\
\text { grained, gravel fine-grained, } 1 / 16-1 / 8 \text { in diameter. }\end{array}$ \\
\hline Mark Group 317 & 88.39 & 91.44 & sand, clay and gravel & $\begin{array}{l}\text { Brown, silty sand with some gravel, sand very fine to me- } \\
\text { dium (mainly fine), gravel fine to medium. }\end{array}$ \\
\hline
\end{tabular}


Appendix 1. Compilation of borehole and aquifer data.-Continued

[cm, centimeter; $\mathrm{m}$, meter; in, inch; ft, feet; \%, percent; ppm, parts per million; $\approx$, approximately equal to; $>$, greater than]

\begin{tabular}{ccccc}
\hline Bore & $\begin{array}{c}\text { Top } \\
(\mathbf{m})\end{array}$ & $\begin{array}{c}\text { Bottom } \\
(\mathbf{m})\end{array}$ & Simplified lithology & Driller's description \\
\hline Mark Group 317 & 91.44 & 97.54 & $\begin{array}{c}\text { sand, clay and trace } \\
\text { gravel }\end{array}$ & $\begin{array}{c}\text { Brown silty sand with some gravel, sand very fine to me- } \\
\text { dium (mainly fine-grained), gravel fine-grained with few } \\
\text { medium-grained gravel. Static water level at 306.42 } \mathrm{ft},\end{array}$ \\
& & & $307 \mathrm{ft}$ from top of 12 in. Stand by to monitor water \\
& & & $\begin{array}{l}\text { levels. Drilled 310.4-320.4 ft. At 320 ft greenish-brown, } \\
\text { sandy silt, well cemented. 1023 stopped circulating } \\
\text { foam. Rig on standby to monitor water level. }\end{array}$
\end{tabular}

Mark Group $317 \quad 97.54 \quad 100.58 \quad \begin{gathered}\text { sand, clay and trace } \\ \text { gravel }\end{gathered} \quad$ Started drilling from $320 \mathrm{ft}$.

Mark Group $317 \quad 100.58 \quad 103.63 \quad$ clay and sand

Greenish-brown sandy silt, very fine-grained sand, well cemented. At $340 \mathrm{ft}$ greenish-brown, sandy silt, sand is very fine to fine-grained, silt well cemented, stopped circulating air/foam, started tripping pipe. Total depth drilled $340 \mathrm{ft}$.

Mark Group 400

Mark Group 400

Mark Group 400

Mark Group 400

Mark Group 400

Mark Group 400
14.02

sand and trace gravel

2.44 sand, clay and gravel

2.59 sand and clay

6.71 sand and gravel

$6.71 \quad 8.23 \quad$ sand and trace gravel

$6.71 \quad 8.23 \quad$ sand and trace gravel

$\begin{array}{ll}8.23 & 14.02 \quad \text { sand and trace gravel }\end{array}$
$14.02 \quad 23.47 \quad$ sand and gravel

\section{Artificial fill, fine-grained sand with silt and gravel, gap- graded, slightly moist, brown with paper fragments.}

Very fine-grained sand with trace silt, poorly graded, slightly moist, brown.

Coarse, sandy gravel with trace fine-medium sand well graded, brown, dry, weakly cemented, very dense.

Very fine-grained sand with some medium-coarse sand and gravel, poorly graded, brown, slightly moist.

Fine-grained sand with some medium-coarse sand and gravel, well graded, light brown, dry, no cementation very dense. Undisturbed sample penetrated 6 in (36-39.5 ft) First bulk sample met with refusal, second bulk sample successful at $39.5-41 \mathrm{ft}$.

Bottom of interval not yet encountered. Fine to mediumgrained sand with some coarse sand and gravel, well graded, slightly moist, reddish-brown. Slight cohesiveness to finer materials. Obtained bulk sample at $58 \mathrm{ft}$. Not enough recovery-will resample tomorrow. Bottom of hole At $58 \mathrm{ft}$ on 4/5/88. Very fine-grained sand with some medium-coarse sand and gravel (to 2 in), well graded reddish-brown, slightly moist, no cementation, very dense, slight cohesiveness in finer materials. 
Appendix 1. Compilation of borehole and aquifer data.-Continued

[cm, centimeter; $\mathrm{m}$, meter; in, inch; $\mathrm{ft}$, feet; \%, percent; ppm, parts per million; $\approx$, approximately equal to; >, greater than]

\begin{tabular}{|c|c|c|c|c|}
\hline Bore & $\begin{array}{l}\text { Top } \\
\text { (m) }\end{array}$ & $\begin{array}{l}\text { Bottom } \\
\text { (m) }\end{array}$ & Simplified lithology & Driller's description \\
\hline Mark Group 400 & 23.47 & 27.43 & $\begin{array}{l}\text { sand, clay and trace } \\
\text { gravel }\end{array}$ & $\begin{array}{l}\text { Gravelly, fine to coarse sand with some silt and trace cob- } \\
\text { bles ( } 4 \text { in) well graded, reddish-brown, slightly moist, } \\
\text { weak concentration, very dense, slight cohesiveness } \\
\text { in finer materials. Considerable rhyolite in gravel and } \\
\text { cobble size. At } 86 \mathrm{ft} \text { same as above, but color change to } \\
\text { brown (not as red), also, ash flow tuff constituents seen } \\
\text { in gravel-sized materials. }\end{array}$ \\
\hline Mark Group 400 & 27.43 & 28.35 & sand and gravel & $\begin{array}{l}\text { Coarser materials, fewer fines, gravelly, medium sand with } \\
\text { trace cobbles, well graded, brown, slightly moist. }\end{array}$ \\
\hline Mark Group 400 & 28.35 & 31.39 & sand, clay and gravel & $\begin{array}{l}\text { (bottom of interval not yet encountered). Gravelly sand } \\
\text { with some silt and trace cobbles ( } 4 \text { in diameter), well } \\
\text { graded, brown, slightly moist, weak concentration, very } \\
\text { dense. Bottom of hole At } 100 \mathrm{ft} \text { on } 4 / 7 / 88 \text {. Gravelly sand } \\
\text { with trace cobbles, well graded, brown, slightly moist, } \\
\text { weak cementation, very dense. }\end{array}$ \\
\hline
\end{tabular}

Mark Group 400

Mark Group 400

Mark Group 400

Mark Group 400

Mark Group 400

Mark Group 400

Mark Group 400
31.39

35.05

41.45

sand, clay and trace gravel

41.45

46.94 sand and trace gravel
48.77

sand, clay and gravel

Gravel sand with cobbles, well graded, dry, grayish-brown.

Very fine to coarse sand with some silt and trace gravel and cobbles, well graded, brown, slightly moist, weak cementation (slight cohesiveness in finer materials).

(bottom of interval not yet encountered) very fine to medium sand with some coarse sand and trace gravel and cobbles, well graded, brown, slightly moist, weak cementation. Bulk sample, 61 blows per 10 in with air hammer, undisturbed sample, 63 blows per 6 in. Bottom of hole At $138 \mathrm{ft}$ on 4/8/88. Started drilling from $138 \mathrm{ft}$. Sand with some gravel and cobbles, well graded, brown, dry, weak cementation.

Very fine to medium sand with silt and gravel, poorly graded, brown, slightly moist, weak cementation, very dense, not friable. Bulk sample, drove 18 in, 88 blows with air hammer undisturbed, drove 12 in.

Gravel sand with cobble (4 ft), well graded, grayish-brown, dry.

Fine to medium sand with coarse sand and gravel, poorly graded, slightly moist, brown (similar to $154-160 \mathrm{ft}$ interval).

Gravelly sand with cobble (4 in), well graded, grayishbrown, dry. 
Appendix 1. Compilation of borehole and aquifer data.-Continued

[cm, centimeter; $\mathrm{m}$, meter; in, inch; ft, feet; \%, percent; ppm, parts per million; $\approx$, approximately equal to; >, greater than]

\begin{tabular}{|c|c|c|c|c|}
\hline Bore & $\begin{array}{l}\text { Top } \\
\text { (m) }\end{array}$ & $\begin{array}{c}\text { Bottom } \\
\text { (m) }\end{array}$ & Simplified lithology & Driller's description \\
\hline Mark Group 400 & 53.04 & 53.64 & sand and gravel & $\begin{array}{l}\text { Fine to medium sand with coarse sand and gravel, poorly } \\
\text { graded, slightly moist, brown (similar to } 154-160 \mathrm{ft} \\
\text { interval). }\end{array}$ \\
\hline Mark Group 400 & 53.64 & 55.17 & sand, clay and gravel & $\begin{array}{l}\text { Very fine to coarse sand with gravel and trace clay, well } \\
\text { graded, brown, slightly moist, weak cementation, very } \\
\text { dense. Bulk sample, drove } 10 \text { in, } 92 \text { blows with air. } \\
\text { Refusal at } 181 \mathrm{ft} \text { less clay. }\end{array}$ \\
\hline Mark Group 400 & 55.17 & 57.30 & sand, clay and gravel & No more clay observed. \\
\hline
\end{tabular}

Mark Group 400

Mark Group 400

Mark Group 400

Mark Group 400

Mark Group 400

Mark Group 400

66.75

69.49

sand, clay and gravel

69.49

70.71
Gravelly sand with trace cobble, poorly graded, grayishbrown, dry.

Fine to medium sand with gravel and cobble, well graded, brown, slightly moist.

Trace of clay, color change to reddish-brown.

Gravelly, fine to medium sand with cobbles, well graded, grayish-brown, dry. At $212 \mathrm{ft}$ color change to brown, sat on large cobble for $\approx 11 / 2$ minutes. At $213.5 \mathrm{ft}$ color change to grayish-brown. At $216 \mathrm{ft}$, bottom of interval not yet encountered. Fine to medium sand with gravel, well graded, brown, slightly moist, no cementation, dense. Bulk sample, drove 12 in, 81 blows with air hammer. Bottom of hole $218 \mathrm{ft}$ on 4/9/88.

Attempted undisturbed sample at $219 \mathrm{ft}$, then started drilling at $218 \mathrm{ft}$. Fine to medium sand with trace gravel, well graded, brown, slightly moist, no cementation, medium dense (estimate) undisturbed sample, Refusal after 2 in.

Fine to medium sand with gravel, coarse sand, trace clay and cobbles, well graded, brown, slightly moist, weak cementation, very dense. At $221 \mathrm{ft}$ clay gone, drier.

Gravelly sand with some cobbles, well graded, brown dry, no cementation, casing driving harder in this interval. 
Appendix 1. Compilation of borehole and aquifer data.-Continued

[cm, centimeter; m, meter; in, inch; ft, feet; \%, percent; ppm, parts per million; $\approx$, approximately equal to; $>$, greater than]

\begin{tabular}{ccccc}
\hline Bore & $\begin{array}{c}\text { Top } \\
(\mathbf{m})\end{array}$ & $\begin{array}{c}\text { Bottom } \\
(\mathbf{m})\end{array}$ & Simplified lithology & Driller's description \\
\hline Mark Group 400 & 70.71 & 74.37 & sand and gravel & $\begin{array}{r}\text { Fine to medium sand with gravel and trace cobbles, poorly } \\
\text { graded (gap-graded), brown, slightly moist, no cementa- } \\
\text { tion, slight cohesion in finer sands. Bulk sample, refusal } \\
\text { at } 8 \text { in, drove } 8 \text { in with } 79 \text { blows by air hammer. }\end{array}$ \\
\end{tabular}

$\begin{array}{llll}\text { Mark Group } 400 \quad 74.37 & 77.11 \quad \text { sand and gravel }\end{array}$

Mark Group 400

Mark Group 400

Mark Group 400

Mark Group 400

Mark Group 400

Mark Group 400

81.69

83.82

sand, clay and gravel
Fine sand with gravel, poorly graded, brown, slightly moist, slight cohesiveness in fines. Grades to trace amounts of gravel.

Gravelly sand with cobble, poorly graded, brown, dry.

Fine sand with gravel, poorly graded, brown, slightly moist, slight cohesiveness in fines. Grades to trace amounts of gravel.

Sandy gravel with cobbles (4 in), well graded, brown, slight moist, no cementation, very dense.

Fine to medium sand with trace gravel, poorly graded, brown, slightly moist, slight cohesion.

Sandy gravel with cobble, well graded, brown, dry, no cementation.

Fine to medium sand with some gravel and trace cobble (3 in), poorly graded, brown, slightly moist, no cementation, slight cohesion in fine sands. At $275 \mathrm{ft}$ sand with gravel and trace silt moderately well graded, brown, slightly moist. At $278 \mathrm{ft}$ moister bulk sample, drove 14.5 in, 56 blows with air hammer. Bottom of hole at $278 \mathrm{ft}$ on $4 / 11 / 88$. Started with undisturbed sample at $279 \mathrm{ft}$ and drilled from $273 \mathrm{ft}$. Adequate recovery for 1 brass ring. At $275 \mathrm{ft}$, bottom of interval not yet encountered. Sand with gravel, well graded, brown, moist (at $280 \mathrm{ft}$ ) no cementation. At $283 \mathrm{ft}$ water table, wet. After hole set open for 1 hour, water level (measured with Mscope) at $283.2 \mathrm{ft}$. Bottom of hole at $288 \mathrm{ft}$ on 4/12/88. Bulk sample, $18 \mathrm{ft}$ in 94 blows with air hammer. Depth to water $283.5 \mathrm{ft}$ from surface. Undisturbed sample at $289 \mathrm{ft}$, recovered 2 rings (12 in). Stared drilling at $288 \mathrm{ft}$.

Sand with gravel, well graded, brown, saturated, no cementation, dense. Bulk sample, 18 in 32 blows with air hammer. Undisturbed sample, full recovery (18 in).

Silty, very fine-grained sand, poorly graded, (max. particle size coarse sand), slight plasticity, brown, saturated, no cementation, dense. Sand heaved up sampler 9 in. Bulk sample, 10 in with 9 blows. 
Appendix 1. Compilation of borehole and aquifer data.-Continued

[cm, centimeter; $\mathrm{m}$, meter; in, inch; ft, feet; \%, percent; ppm, parts per million; $\approx$, approximately equal to; >, greater than]

\begin{tabular}{|c|c|c|c|c|}
\hline Bore & $\begin{array}{l}\text { Top } \\
\text { (m) }\end{array}$ & $\begin{array}{c}\text { Bottom } \\
\text { (m) }\end{array}$ & Simplified lithology & Driller's description \\
\hline Mark Group 400 & 90.92 & 91.07 & clay and sand & $\begin{array}{l}\text { Very fine-grained sandy silt with some clay, (max. particle } \\
\text { size medium-sand, <5\%), very stiff, low plasticity, light } \\
\text { brown, moist, no cementation, contains small roots and } \\
\text { red staining near root inclusions. At } 298.8 \mathrm{ft} \text {, (bottom of } \\
\text { interval not yet encountered). Very fine-grained sandy } \\
\text { silt, poorly graded, brown, saturated, no cementation. } \\
\text { Grades to thicker material with large gravel at } 303 \mathrm{ft} \\
\text { depth. Bottom of hole at } 303 \mathrm{ft} \text { on } 4 / 13 / 88 \text {. Bulk sample } \\
\text { at } 303 \mathrm{ft}, 12 \text { in recovery, easy penetration. }\end{array}$ \\
\hline
\end{tabular}

Mark Group $400 \quad 92.35 \quad 92.96 \quad$ sand and trace gravel

Mark Group 400

92.96

96.93

clay and sand

Mark Group 400

Mark Group 400

99.67

100.58

sand and clay

Mark Group 400

100.58

103.02

sand, clay and trace
gravel
Started drilling at $303 \mathrm{ft}$ depth. Fine to medium sand with trace gravel (to 3 in diameter), poorly graded, brown, saturated, no cementation, loose (not dense). Bulk sample at $308 \mathrm{ft}$, recovered $18 \mathrm{in}$.

Very fine sandy silt with some clay, (max. particle size medium sand, $<5 \%$ ), low dry strength, medium stiff, none to medium plasticity (varies throughout, moist, light brown, no cementation, contains black, organic layered staining. Bulk sample at $313 \mathrm{ft}$, recovered $14 \mathrm{in}$. Undisturbed sample at $315 \mathrm{ft}$, recovered $18 \mathrm{in}$.

Bulk sample at $318 \mathrm{ft}, 123$ in recovery showed gradational change from fines to sands. Fine to medium sand with trace silt, poorly graded, brown, saturated, no cementation, loose. Grades from fine materials to coarser materials with trace gravel at $320 \mathrm{ft}$. At $321 \mathrm{ft}$ (bottom of interval not yet encountered) clayey silt with some sand, low dry strength, medium stiff, medium plasticity, light grayish-brown, moist, no cementation with organic materials (possible rootlets). Bulk sample at $323 \mathrm{ft}, 12$ in recover. Bottom of hole at $323 \mathrm{ft}$ on 4/14/88.

Started drilling from $323 \mathrm{ft}$. No water in hole at beginning of day. Silty sand, poorly graded, light brown, slightly moist, no cementation, dense, no plasticity. This $(\approx 1 / 4$ in thick) medium-grained sand layers throughout. Bulk sample at $328 \mathrm{ft}$, recovered $12 \mathrm{in}$.

Fine to medium-grained sand with trace silt, poorly graded, reddish brown, slightly moist, subrounded grains, no cementation. Contains thin layers (4 in or less) of gray silty clay with minor organic materials and subrounded quartz pebbles (large sand-pea size gravel size). Bulk sample at $333 \mathrm{ft}$, recovered 8 in. Undisturbed sample at $334 \mathrm{ft}$, recovered 14 in.

Started drilling from $343 \mathrm{ft}$. Water in the hole could not be measured because drill stem was in hole. Fine sandy silt, low dry strength, no plasticity, light brown, slightly moist, firm, blocky fracture, no cementation. 
Appendix 1. Compilation of borehole and aquifer data.-Continued

[cm, centimeter; m, meter; in, inch; ft, feet; \%, percent; ppm, parts per million; $\approx$, approximately equal to; $>$, greater than]

\begin{tabular}{|c|c|c|c|c|}
\hline Bore & $\begin{array}{l}\text { Top } \\
\text { (m) }\end{array}$ & $\begin{array}{c}\text { Bottom } \\
\text { (m) }\end{array}$ & Simplified lithology & Driller's description \\
\hline Mark Group 400 & 105.16 & 105.77 & sand, clay and gravel & $\begin{array}{l}\text { Sand with gravel, well graded, brown, saturated, no cemen- } \\
\text { tation. At } 347 \mathrm{ft} \text { (bottom of interval not yet encountered) } \\
\text { silty sand, poorly graded (max. particle size fine sand), } \\
\text { very low dry strength, no plasticity, light brown, slightly } \\
\text { moist, no cementation. Bulk sample at } 348 \mathrm{ft} \text {, recovered } \\
12 \mathrm{in} \text {. Bottom of hole at } 348 \mathrm{ft} \text { on } 4 / 18 / 88 \text {. }\end{array}$ \\
\hline
\end{tabular}

Mark Group $400 \quad 106.98 \quad 107.90 \quad$ clay and sand

Mark Group 400

Mark Group 400

Mark Group 400

Mark Group 400

111.56 gravel

108.20

108.36

109.73 gravel sand, clay and trace

clay, sand and trace

sand, clay and trace
gravel

sand, clay and trace
gravel

(same as 351-354 ft).

tarted drilling from $348 \mathrm{ft}$. Sandy silt (maximum particle size fine sand), very low dry strength, no plasticity, light brown, moist, dense, no cementation.

Fine to medium sand with trace silt, gravel and cobble $(\approx 5 \%)$, poorly graded, brown, saturated, subangular grains, loose, no cementation. Undisturbed sample at $353 \mathrm{ft}, 18$ in recovery. Bulk sample at $355 \mathrm{ft}, 12$ in recovery.

Silty sand with trace gravel and cobble, poorly graded, brown, saturated, loose, no cementation. Contains blocks and thin, non-continuous lenses of sandy silt (as in 347-354 ft interval) Inner casing dropped into hole 355-358 ft. Welded temporary safety bar onto casing to hold it up. Bulk sample at $358 \mathrm{ft}, 12$ in recovery, $360 \mathrm{ft}$ casing driving harder.

Fine-grained sand with some silt and trace medium to coarse sand and cobble $(\approx 15 \%$ ) (cobble to $\approx 6 \mathrm{ft}$ diameter), poorly graded (gap graded), brown, saturated, loose, no cementation. Bulk sample $363 \mathrm{ft}, 12$ in recovery. At $366 \mathrm{ft}$, bottom of interval not yet encountered. Gravelly sand with cobbles, well graded, brown, saturated (producing water). Bottom of hole at $368 \mathrm{ft}$ on 4/19/88. Water level $328.3 \mathrm{ft}$ below ground surface. Bulk sample at $368 \mathrm{ft}, 14$ in recovery. Started drilling at $368 \mathrm{ft}$.

Mark Group 400

112.17

112.32

sand, clay and gravel

Fine-grained sand with silt and cobbles $(\approx 3$ to 4 in diameter), very poorly graded (gap graded) brown, saturated, loose, non-stratified, no cementation.

Very fine to fine-grained sand with trace medium sand and gravel, very poorly graded, brown, wet, moderately dense, non-stratified, no cementation. Contains white, coarse-grained sand-sized inclusions, possibly a quartz altered to clay, that breaks across the grains. At $370 \mathrm{ft}$ trace gravel and cobbles. Bulk sample at $373 \mathrm{ft}, 18$ in recovery. Undisturbed sample at $375 \mathrm{ft}, 14$ in recovery $\approx 4$ in slough. 
Appendix 1. Compilation of borehole and aquifer data.-Continued

[cm, centimeter; $\mathrm{m}$, meter; in, inch; ft, feet; \%, percent; ppm, parts per million; $\approx$, approximately equal to; >, greater than]

\begin{tabular}{|c|c|c|c|c|}
\hline Bore & $\begin{array}{l}\text { Top } \\
\text { (m) }\end{array}$ & $\begin{array}{c}\text { Bottom } \\
\text { (m) }\end{array}$ & Simplified lithology & Driller's description \\
\hline Mark Group 400 & 114.00 & 116.13 & sand and gravel & $\begin{array}{l}\text { Gravelly sand with cobble, very well graded, brown, } \\
\text { saturated (good water producer), loose, no cementation } \\
\text { (water everywhere while drilling). Bulk sample at } 378 \\
7 \text { in recovery. Rig chatter at } 381 \mathrm{ft} \text {. }\end{array}$ \\
\hline Mark Group 400 & 116.13 & 117.04 & sand and gravel & $\begin{array}{l}\text { Sandy gravel with cobble, well graded, brown, saturated, } \\
\text { dense, no cementation. Bulk sample at } 383 \mathrm{ft}, 12 \text { in re- } \\
\text { covery. Bottom of hole at } 383 \mathrm{ft} \text { on } 4 / 20 / 88 \text {. Static wate } \\
\text { level at } 329 \mathrm{ft} \text { from surface. Started drilling from } 383 \mathrm{ft} \\
\text { casing driving very hard, considerable rig chatter. }\end{array}$ \\
\hline Mark Group 400 & 117.04 & 126.80 & sand and gravel & $\begin{array}{l}\text { Cobble, large gravel, well graded, colors depend on } \\
\text { individual grains, primarily quartz (white) and some } \\
\text { feldspathic minerals, saturated. Bulk sample at } 388 \mathrm{ft} \text {, } \\
\text { drove in } 5 \text { in, recovered } 2 \text { cobbles and } 3 \text { large gravel. } \\
\text { Continued drilling without casing the hole. Did not } \\
\text { sample, refusal in sampling the same materials. Rig } \\
\text { chatter continuing. At } 411 \mathrm{ft} \text { color change in water, } \\
\text { lighter, fewer fines. Hole is producing more water. }\end{array}$ \\
\hline
\end{tabular}

Mark Group 400

Mark Group 400

Mark Group 400

Mark Group 400

Mark Group 400

Mark Group 400
126.80

128.02

sand and gravel

128.02

134.11

sand and gravel

$134.11 \quad 138.38 \quad$ sand and trace gravel

$138.38 \quad 140.21 \quad$ sand

$140.21 \quad 140.82 \quad$ sand and clay
Very fine-medium sand, poorly graded, white to grayish white (primarily quartz), saturated, moderately well cemented. Either thin layer or $4 \mathrm{ft}$ diameter boulder.

Cobble gravel with boulders, light brown with other colors depending on individual grains, saturated. Thin zones of either sandstone layer (as in 416-420 ft interval) or sandstone boulder through this zone.

Fine to medium sand with trace coarse sand and pea-size gravel, poorly graded, white to grayish white (primarily quartz), saturated, moderately cemented.

Medium sand, very poorly graded, brown, saturated, rounded grains, no cementation.

Very fine-medium sane with trace silt, moderately well graded, brown, saturated, weak cementation with some moderate cementation in gravel-size-masses. Bulk sample at $460 \mathrm{ft}$, recovered $12 \mathrm{in}$.

Very fine-medium sand, poorly graded, white to grayish white (primarily quartz grains with quartz Cementation), saturated, moderately well cemented. 
Appendix 1. Compilation of borehole and aquifer data.-Continued

[cm, centimeter; $\mathrm{m}$, meter; in, inch; $\mathrm{ft}$, feet; \%, percent; ppm, parts per million; $\approx$, approximately equal to; >, greater than]

\begin{tabular}{|c|c|c|c|c|}
\hline Bore & $\begin{array}{l}\text { Top } \\
\text { (m) }\end{array}$ & $\begin{array}{c}\text { Bottom } \\
\text { (m) }\end{array}$ & Simplified lithology & Driller's description \\
\hline Mark Group 400 & 143.26 & 160.32 & sand and trace gravel & $\begin{array}{l}\text { Very fine-medium sand, poorly graded, brown cementation } \\
\text { with multi-colored grains (primarily brown), saturated, } \\
\text { weak cementation with some moderate cementation } \\
\text { in gravel-size masses. at } 482 \mathrm{ft} \text { with coarse sand-size } \\
\text { quartz. At } 505 \mathrm{ft} \text {, same as above with gravel-size quartz. } \\
\text { At } 526 \mathrm{ft} \text {, (bottom of interval not yet encountered). } \\
\text { Cobble gravel with trace sand, well graded, color de- } \\
\text { pendent upon individual grains and with brown sand, no } \\
\text { cementation. Total depth of boring at } 537 \mathrm{ft} \text {. }\end{array}$ \\
\hline
\end{tabular}

Mark Group 401

Mark Group 401

Mark Group 401

Mark Group 401

Mark Group 401

Mark Group 401

Mark Group 401

13.72

20.73

sand and gravel

Mark Group 401
1.83 sand and trace gravel

4.57 sand and gravel

8.84 sand and trace gravel

9.14 sand

10.67 sand and gravel

$10.67 \quad 13.72 \quad$ sand and gravel
Fine medium sand with trace gravel, poorly graded, light brown, slightly moist, no cementation, contains organic material (roots).

Sandy gravel with trace cobble, poorly graded, grayish brown, dry, no cementation, contains roots to $\approx 10 \mathrm{ft}$ depth.

Fine to medium sand with trace coarse sand and gravel $(\approx 5 \%$ ), poorly graded, light brown, dry, no cementation. Bulk sample at $18 \mathrm{ft}$, recovered 13 in 46 blows with air hammer. Blow counts given per 6 in interval. At $27 \mathrm{ft}$ more gravel (gravelly sand).

Fine to medium sand, very poorly graded, black and brown grains, dry, no cementation.

Sandy gravel with cobble, well graded, grayish brown, dry, no cementation.

Fine gravelly sand with trace cobble, well graded, light brown, dry, moderately dense, no cementation, $39-40 \mathrm{ft}$ cobble/gravel layer. Undisturbed sample at $38 \mathrm{ft}$, recovered 18 in, 123 blows with air hammer.

Sand with fine gravel $(\approx 30 \%)$ and trace cobble $(\approx 5 \%$, (4 ft), well graded, reddish brown, slightly moist, moderately dense, no cementation, slight cohesion in finer sands. Bulk sample at $58 \mathrm{ft}$, drove 12 in 89 blows with air burner. At $62 \mathrm{ft}$ more gravel and cobble.

Sandy gravel with cobble $(\approx 30 \% / 50 \% / 20 \%$ sand/gravel/ cobble), well graded, reddish brown, dry. 
Appendix 1. Compilation of borehole and aquifer data.-Continued

[cm, centimeter; $\mathrm{m}$, meter; in, inch; ft, feet; \%, percent; ppm, parts per million; $\approx$, approximately equal to; $>$, greater than]

\begin{tabular}{ccccc}
\hline Bore & $\begin{array}{c}\text { Top } \\
(\mathbf{m})\end{array}$ & $\begin{array}{c}\text { Bottom } \\
(\mathbf{m})\end{array}$ & Simplified lithology & Driller's description \\
\hline Mark Group 401 & 21.34 & 22.25 & sand, clay and gravel & $\begin{array}{c}\text { Find-medium sand with gravel }(\approx 20 \%) \text { and trace cobble, } \\
\text { poorly graded, light brown, slightly moist, no cementa- } \\
\text { tion. At } 73 \mathrm{ft} \text { fine-medium sandy gravel with trace silt } \\
\text { and cobble, well graded, brown, slightly moist (in fine } \\
\text { sands), no cementation. Sat on large cobble for 3/4 min- } \\
\end{array}$ \\
& & & utes at $73 \mathrm{ft}$. Bulk sample at $78 \mathrm{ft}$, refusal at 9 in penetra- \\
& & & tion. Bottom of hole at $78 \mathrm{ft}$ on $5 / 3 / 88$.
\end{tabular}

$\begin{array}{lll}\text { Mark Group } 401 \quad 22.25 & 24.08 \quad \text { sand, clay and gravel }\end{array}$

Mark Group 401

24.08

31.70

sand, clay and gravel

Mark Group 401

Mark Group 401

Mark Group 401

Mark Group 401

Mark Group 401

45.72

46.33

sand and gravel

Mark Group 401

46.33

49.99
Started drilling from $78 \mathrm{ft}$, undisturbed sample at $79 \mathrm{ft}$, recovered 5 in. Refusal thereafter.

Sandy gravel with small to large cobbles and trace silt, well graded, $\approx 30 / 50 / 20 \%$ sand/gravel/cobble, brown, slightly moist, no cementation, slight cohesiveness in finer sands. Casing driving hard through cobbles. Bulk sample at $98 \mathrm{ft}$, Refusal after $71 / 2$ in 105 blows with air hammer.

At $104 \mathrm{ft}$ casing driving easier. Fine, medium sand with gravel $(\approx 30 \%)$ and trace cobble and clay, well graded, reddish brown, moist, weak cementation. At $113 \mathrm{ft}$ color change to brown, more gravel, slightly moist. At $118 \mathrm{ft}$ color change to reddish-brown undisturbed sample at $118 \mathrm{ft}$, drove 12 in 182 blows with air hammer.

Sandy gravel with cobble, well graded, brown, dry, no cementation. At $127 \mathrm{ft}$ slightly moist. At $133 \mathrm{ft}$ color change, light brown (134-135 ft cobble/gravel).

Gravelly medium-coarse sand with trace clay, well graded, reddish brown, slightly moist, weak cementation. Bulk sample at $138 \mathrm{ft}$, Refusal after 8 in 74 blows with air hammer.

Gravelly sand with trace cobble, well graded, reddish brown slightly moist.

Sandy gravel with cobble, well graded, brown, dry. At $152 \mathrm{ft}$ gravelly medium-coarse sand with clay, well graded, reddish brown, slightly moist, weak cementation. Bottom of hole at $158 \mathrm{ft}$ on 5/4/88. Started drilling from $158 \mathrm{ft}$. Bulk sample at $158 \mathrm{ft}$, refusal after $10 \mathrm{in}$, 137 blow with air hammer.

Gravel medium-coarse sand with clay $(\approx 20 \%)$ and cobble, well graded, reddish brown, slightly moist, weak cementation. 
Appendix 1. Compilation of borehole and aquifer data.-Continued

[cm, centimeter; $\mathrm{m}$, meter; in, inch; $\mathrm{ft}$, feet; \%, percent; ppm, parts per million; $\approx$, approximately equal to; >, greater than]

\begin{tabular}{|c|c|c|c|c|}
\hline Bore & $\begin{array}{l}\text { Top } \\
\text { (m) }\end{array}$ & $\begin{array}{l}\text { Bottom } \\
(\mathrm{m})\end{array}$ & Simplified lithology & Driller's description \\
\hline Mark Group 401 & 49.99 & 52.12 & sand & $\begin{array}{l}\text { Gravelly fine-medium sand, well graded, brown, slightly } \\
\text { moist, no cementation. At } 170 \mathrm{ft} \text { trace clay. }\end{array}$ \\
\hline Mark Group 401 & 52.12 & 53.34 & sand and gravel & $\begin{array}{l}\text { Sandy gravel with trace clay }(\approx 5 \%) \text { well graded, brown, } \\
\text { slightly moist. }\end{array}$ \\
\hline Mark Group 401 & 53.34 & 53.64 & sand and gravel & $\begin{array}{l}\text { Fine to medium sand with gravel and trace clay, poorly } \\
\text { graded, brown, slightly moist. }\end{array}$ \\
\hline Mark Group 401 & 53.64 & 55.17 & sand and clay & $\begin{array}{l}\text { Gravelly fine-medium sand with trace clay, well graded, } \\
\text { light brown, dry, no cementation. Bulk sample at } 178 \mathrm{ft} \text {, } \\
\text { refusal at } 6 \text { in, } 58 \text { blows with air hammer. }\end{array}$ \\
\hline Mark Group 401 & 57.91 & 58.52 & sand and gravel & $\begin{array}{l}\text { cobble gravel with sand, well-graded, light brown, slightly } \\
\text { moist. }\end{array}$ \\
\hline Mark Group 401 & 58.52 & 59.44 & sand and gravel & $\begin{array}{l}\text { Sandy gravel with trace cobble ( } \geq 4 \text { in), well graded, } \\
\text { brown, slightly moist. }\end{array}$ \\
\hline Mark Group 401 & 59.44 & 60.05 & sand and trace gravel & $\begin{array}{l}\text { Fine to medium sand with trace gravel and cobble }(\approx 15 \% \\
\text { total) poorly graded, brown, slightly moist }(\approx 5 \mathrm{in}) \text {. Bulk } \\
\text { sample at } 198 \mathrm{ft} \text {, refusal after } 71 / 2 \mathrm{in}, 125 \text { blows with air } \\
\text { hammer. }\end{array}$ \\
\hline Mark Group 401 & 62.18 & 62.48 & sand and clay & $\begin{array}{l}\text { Fine to medium sand with trace clay and gravel, poorly } \\
\text { graded, brown, moist, cohesive. }\end{array}$ \\
\hline Mark Group 401 & 62.48 & 64.62 & sand and gravel & $\begin{array}{l}\text { Sandy gravel with cobble, well graded, brown, slightly } \\
\text { moist. }\end{array}$ \\
\hline Mark Group 401 & 64.62 & 64.92 & sand and trace gravel & $\begin{array}{l}\text { Gravelly sand with trace cobble, well graded, brown, } \\
\text { slightly moist. }\end{array}$ \\
\hline Mark Group 401 & 64.92 & 66.14 & sand and gravel & $\begin{array}{l}\text { Sandy gravel with cobble, well graded, brown, slightly } \\
\text { moist. }\end{array}$ \\
\hline Mark Group 401 & 66.14 & 66.45 & sand and trace gravel & $\begin{array}{l}\text { Gravelly sand, bulk sample at } 218 \mathrm{ft} \text {, refusal after } 6 \text { in, } \\
79 \text { blows with air hammer. }\end{array}$ \\
\hline
\end{tabular}


Appendix 1. Compilation of borehole and aquifer data.-Continued

[cm, centimeter; $\mathrm{m}$, meter; in, inch; ft, feet; \%, percent; ppm, parts per million; $\approx$, approximately equal to; >, greater than]

\begin{tabular}{ccccc}
\hline Bore & $\begin{array}{c}\text { Top } \\
(\mathbf{m})\end{array}$ & $\begin{array}{c}\text { Bottom } \\
(\mathbf{m})\end{array}$ & Simplified lithology & Driller's description \\
\hline Mark Group 401 & 66.45 & 68.88 & sand and gravel & $\begin{array}{c}\text { Sandy gravel with cobble (cobble in sample 4 in), well } \\
\text { graded brown, slightly moist. Rig chatter 221-226 ft. }\end{array}$
\end{tabular}

Mark Group 401

Mark Group 401

Mark Group 401

Mark Group 401

Mark Group 401

Mark Group 401

Mark Group 401

Mark Group 401

Mark Group 401

Mark Group 401

Mark Group 401
68.88

69.80

sand and trace gravel

69.80

70.4

sand, clay and gravel

$\begin{array}{lll}70.41 & 72.24 & \text { sand and gravel }\end{array}$

72.24

72.54

sand, clay and trace gravel

$72.54 \quad 72.85 \quad$ sand and gravel

72.85

75.29

sand and gravel

75.29

78.33

sand, clay and trace gravel

$78.33 \quad 78.94 \quad$ sand and trace gravel

78.33

78.94

sand, clay and trace gravel

78.94

82.91

sand and trace gravel
83.52 sand, clay and trace gravel
Fine to medium sand with trace gravel and cobble, poorly graded, brown, moist.

Sand with gravel and trace clay and cobble, well graded, brown, moist. Rig chatter 231-233 ft.

Fine to medium sandy gravel with cobble (6 in), gapgraded, brown, moist.

Gravelly sand with trace clay and cobble, poorly graded (gap graded), brown, moist. Bulk sample at $238 \mathrm{ft}$, refusal after 31/2 in. Drove 59 blows with air hammer, bouncing off bottom.

Gravel with sand and trace cobble, well graded, brown, moist, no cementation. Bottom of hole at $238 \mathrm{ft}$ On $5 / 5 / 88$.

Started drilling from $238 \mathrm{ft}$ depth. Sand with gravel and cobble, well graded brown moist. Grades to cobble.

Gravelly sand with trace cobble $(\approx 5 \%)$ well graded, brown, very moist. At $257 \mathrm{ft}$, fine to medium sand with trace coarse gravel $(\approx 10 \%)$, poorly graded, brown, very moist, none to weak cementation. Bottom of hole at $258 \mathrm{ft}$ on $5 / 6 / 88$.

Fine to medium sand with trace coarse gravel $(\approx 10 \%)$, poorly graded, brown, very moist, none to weak cementation.

Started drilling from $258 \mathrm{ft}$. Bulk sample at $258 \mathrm{ft}$, recovered $\approx 4$ in. Lost sample from sampler shoe. Undisturbed sample at $259 \mathrm{ft}$, recovered 9 in.

Fine-coarse sand with trace gravel, well graded, brown, very moist, weak cementation. Casting driving very easily. Bulk sample at $268 \mathrm{ft}$, recovered $\approx 5$ in.

Very fine-grained sand with clay and trace gravel, poorly graded, brown, very moist, weak cementation. 
Appendix 1. Compilation of borehole and aquifer data.-Continued

[cm, centimeter; m, meter; in, inch; ft, feet; \%, percent; ppm, parts per million; $\approx$, approximately equal to; $>$, greater than]

\begin{tabular}{|c|c|c|c|c|}
\hline Bore & $\begin{array}{l}\text { Top } \\
\text { (m) }\end{array}$ & $\begin{array}{c}\text { Bottom } \\
\text { (m) }\end{array}$ & Simplified lithology & Driller's description \\
\hline Mark Group 401 & 83.52 & 86.87 & clay and sand & $\begin{array}{l}\text { Silt with very fine sand and clay, low dry strength, slight } \\
\text { plasticity, greenish light brown, very moist, stiff. At } \\
276.5 \mathrm{ft} \text { more very fine-grained sand (sandy silt), trace } \\
\text { clay. Undisturbed sample at } 277 \mathrm{ft} \text {, recovered } 12 \text { in. } \\
\text { Bulk sample at } 278 \mathrm{ft} \text {, recovered } 15 \mathrm{in} \text {. At } 281 \mathrm{ft} \text { with } \\
\text { some clay, less sand (as at } 274 \mathrm{ft} \text { ). Bulk sample at } \\
283 \mathrm{ft} \text {, recovered } 15 \mathrm{in} \text {. At } 285 \mathrm{ft} \text { silty fine-grained sand } \\
\text { with trace clay, medium dry strength, slight plasticity, } \\
\text { greenish-light brown, wet, stiff, some weak cementa- } \\
\text { tion in gravel-size masses. Cuttings plugging up outlet. } \\
\text { Stopped drilling to clean out the outlet. Bulk sample at } \\
288 \mathrm{ft} \text {, recovered } 9 \text { in (sampler wet on outside). Undis- } \\
\text { turbed sample at } 289 \mathrm{ft} \text {, recovered } 15 \text { in. Bottom of hole } \\
\text { at } 288 \mathrm{ft} \text {, on } 5 / 7 / 88 .\end{array}$ \\
\hline
\end{tabular}

Mark Group $401 \quad 86.87 \quad 89.92 \quad$ clay and sand

Mark Group $401 \quad 89.92 \quad 94.79 \quad$ clay and sand

Mark Group 401

94.79

95.55

sand and clay

Mark Group 401

95.55

98.15

clay and sand

Mark Group 401
98.15

99.36
Depth to water level $286.96 \mathrm{ft}$. Started drilling from $288 \mathrm{ft}$ silty fine-grained sand with trace clay moderate dry strength, slight plasticity, greenish-light brown, wet, stiff, some weak cementation in gravel-size masses. Saturated at $287 \mathrm{ft}$. Bulk sample at $293 \mathrm{ft}$, recovered $12 \mathrm{in.}$ Undisturbed sample at $294 \mathrm{ft}$, recovered $12 \mathrm{in.} \mathrm{At}$ $295 \mathrm{ft}$ silty clay, high dry strength, no plasticity, grayish light brown, saturated, moderately strong cementation, blocky fracture, strongly calcareous with shell inclusions. Bulk sample at $298 \mathrm{ft}$, recovered 5 in. Bulk sample at $303 \mathrm{ft}$, recovered $3 \mathrm{in}, 307 \mathrm{ft}$ color change to brown, not calcareous. Bulk sample at $308 \mathrm{ft}$, recovered $11 / 2$ in. Ran small split barrel down hole and recovered 7 more in. Bottom of hole at $308 \mathrm{ft}$ on 5/9/88.

Depth to water level $302.9 \mathrm{ft}$. Started drilling from $308 \mathrm{ft}$ (drove 6 in casing from $298 \mathrm{ft}$. Silty clay, high dry strength, no plasticity, brown, saturated, moderately strong cementation, blocky fracture.

Very fine-grained sand with silt, very poorly graded, light brown, saturated, strong cementation, platy cleavage. Bulk sample at $313 \mathrm{ft}$, recovered $12 \mathrm{in.} \mathrm{Undisturbed}$ sample at $314 \mathrm{ft}$, recovered $15 \mathrm{in}$.

Silt with clay and some fine-grained sand, (25\% sand), very low dry strength, no plasticity, greenish-light brown, saturated, soft with gravel-sized moderately cemented messes. Bulk sample at $318 \mathrm{ft}$, recovered $10 \mathrm{in}$. Bulk sample at $323 \mathrm{ft}$, recovered 5 in.

Very fine-grained sand with silt, very poorly graded, light brown, saturated, strong cementation, platy cleavage, mildly reactive with acid (326-327 ft casing driving harder). 
Appendix 1. Compilation of borehole and aquifer data.-Continued

[cm, centimeter; $\mathrm{m}$, meter; in, inch; ft, feet; \%, percent; ppm, parts per million; $\approx$, approximately equal to; $>$, greater than]

\begin{tabular}{|c|c|c|c|c|}
\hline Bore & $\begin{array}{l}\text { Top } \\
\text { (m) }\end{array}$ & $\begin{array}{c}\text { Bottom } \\
(\mathrm{m})\end{array}$ & Simplified lithology & Driller's description \\
\hline Mark Group 401 & 99.36 & 101.50 & clay and sand & $\begin{array}{l}\text { Bulk sample at } 328 \mathrm{ft} \text {, recovered } 14 \text { in with } 2 \mathrm{ft} \text { diameter- } \\
\text { split barrel, no recovery on large sampler. Clay with } \\
\text { trace very fine sand and silt, low dry strength, moderate- } \\
\text { ly stiff, no plasticity, tan, saturated (but appears moist) } \\
\text { homogeneous, strong reaction with acid. Bottom of hole } \\
\text { at } 333 \mathrm{ft} \text { on } 5 / 10 / 88 \text {. }\end{array}$ \\
\hline
\end{tabular}

Mark Group $401 \quad 101.50 \quad 102.11 \quad$ clay and sand

Mark Group $401 \quad 102.11 \quad 102.72 \quad$ sand and clay

Mark Group $401 \quad 102.72 \quad 103.94 \quad$ clay and sand

Mark Group $401 \quad 103.94 \quad 105.46 \quad$ sand and clay

Mark Group $401 \quad 105.46 \quad 107.90 \quad$ sand

Mark Group 401

109.42 sand and clay

Mark Group 401

109.42

110.95

sand and clay

Mark Group 401

110.95

112.17 sand and trace gravel
Started drilling from $33 \mathrm{ft}$, depth to water $328.35 \mathrm{ft}$. Bulk sample at $333 \mathrm{ft}$, recovered $12 \mathrm{in}$. Undisturbed sample at $334 \mathrm{ft}$, recovered $14 \mathrm{in}$. clayey silt, medium dry strength, no plasticity, tan, saturated, soft with white, fine to coarse gravel-size cemented masses, no reaction to acid.

Silty sand, poorly graded, light brown, saturated, moderately well cemented (difficulty driving casing). Bulk sample at $338 \mathrm{ft}$, recovered $11 \mathrm{in}$.

Silt with some very fine sand $(\approx 25 \%)$, low dry strength, no plasticity, light brown, wet, very stiff, weak cementation with white coarse-sand size inclusions of silt-sized particles, moderately reactive with acid. Bulk sample at $343 \mathrm{ft}$, recovered $71 / 2$ in.

Silty sand, poorly grade, moderate dry strength, light brown, saturated, moderately well cemented, platy fracture, medium dry strength (casing driving hard through consolidated material). Bulk sample at $348 \mathrm{ft}$, recovered 6 in.

Fine-grained sand with trace coarse and sand ( $\approx 5 \%)$, poorly graded, brown, saturated, strong cementation, medium dry strength, strong reaction with acid, Casing driving extremely hard. Producing water from this interval. Bulk sample $353.5 \mathrm{ft}$, recovered 6 in. $354 \mathrm{ft}$, looser material, weak cementation, more silt. Bottom of hole at $358 \mathrm{ft}$ on $5 / 11 / 88$.

Depth to water $320.2 \mathrm{ft}$. Started drilling from $358 \mathrm{ft}$. Bulk sample at $358 \mathrm{ft}$, recovered 3 in. Silty fine-grained sand with trace coarse sand $(\approx 5 \%)$, poorly graded, brown, saturated, strong cementation, medium dry strength strong reaction with acid.

Fine to medium sand with some silt and trace coarse sand, poorly graded, brown, saturated, weak cementation, weak dry strength, reaction with acid, trace black organic material. Bulk sample at $363 \mathrm{ft}$, recovered 11/2 in.

Gravelly sand, well graded, brown, saturated, weak cementation. Bulk sample at $368 \mathrm{ft}$, recovered 13 in. 
Appendix 1. Compilation of borehole and aquifer data.-Continued

[cm, centimeter; m, meter; in, inch; ft, feet; \%, percent; ppm, parts per million; $\approx$, approximately equal to; $>$, greater than]

\begin{tabular}{|c|c|c|c|c|}
\hline Bore & $\begin{array}{l}\text { Top } \\
\text { (m) }\end{array}$ & $\begin{array}{l}\text { Bottom } \\
(\mathrm{m})\end{array}$ & Simplified lithology & Driller's description \\
\hline Mark Group 401 & 112.17 & 112.78 & $\begin{array}{l}\text { sand, clay and trace } \\
\text { gravel }\end{array}$ & $\begin{array}{l}\text { Fine to medium sand with trace silt and coarse sand, poorly } \\
\text { graded, brown, saturated, no cementation. }\end{array}$ \\
\hline Mark Group 401 & 112.78 & 114.30 & sand and gravel & $\begin{array}{l}\text { Gravelly sand with cobbles ( } 4 \text { in), } \approx 40 \% \text { gravel, } 40 \% \text { sand, } \\
20 \% \text { cobble, well graded, brown, saturated, no cemen- } \\
\text { tation. Undisturbed sample at } 373 \mathrm{ft} \text {, recovered } 14 \mathrm{in} \text {. } \\
\text { Bulk sample at } 274 \mathrm{ft} \text {, recovered } 10 \mathrm{in} \text {. At } 374 \mathrm{ft} \text { cobble } \\
\text { gravel with some sand }(\approx 25 \%) \text { well graded, brown and } \\
\text { colors of individual grains, saturated, no cementation, } \\
\text { maximum grain size } 4 \text { in. Bulk sample at } 378 \mathrm{ft} \text {, recov- } \\
\text { ered } 4 \text { in. Considerable rig chatter } 380 \mathrm{ft} \text {, large cobbles. } \\
\text { Stopped to hose off radiator, rig too hot at } 390 \mathrm{ft} \text {. Bottom } \\
\text { of hole at } 399 \mathrm{ft} \text { on } 5 / 12 / 88 \text {. }\end{array}$ \\
\hline
\end{tabular}

Mark Group $401 \quad 114.30 \quad 128.02 \quad$ sand and gravel

Mark Group 402

Mark Group 402

Mark Group 402

Mark Group 402

3.66

4.57

sand and gravel

4.57

6.71

sand and gravel

Mark Group 402
12.34 sand and gravel
Started drilling from $399 \mathrm{ft}$. Cobble gravel with trace sand, well graded, brown and colors of individual grains, saturated, no cementation, cobbles $>5$ in diameter. Producing water. Considerable rig chatter throughout. Total depth of boring at $420 \mathrm{ft}$.

Sand with gravel, moderate yellowish to brown, sand is fine grain with fine gravel, subrounded. Sand $90 \%$ gravel $10 \%$, slightly moist, $0-8 \mathrm{ft}$, sample is gap graded.

Sand and gravel is about 50/50, gravel fine to medium pale yellowish-brown, variable rock types.

Sand and gravel is about 50/50, gravel angular to subangular, light gray to gray.

Less gravel $(<20 \%)$.

Sand with gravel same as above. Bulk sample at $22 \mathrm{ft}$ met with refusal. No sample recovered probably due to cobbles and gravel.

Bulk sample at $25 \mathrm{ft}$ met with refusal, recovered only cobble-sized rocks. Sand with gravel, moderate yellowish-brown to gray-brown, sand is fine to medium with gravel to cobble-size (20-25\%). Zone, gravel content $30 \%, 33-34 \mathrm{ft}$ sand content higher mostly fine grain with silt $38-40.5 \mathrm{ft}$. Bottom of hole at $40.5 \mathrm{ft}$. Started drilling at $40.5 \mathrm{ft}$. Bulk sample at $43.5 \mathrm{ft}$, drove 14 in with 450 blows, recovered 7 in. Most of sand lost from sample. Description of recovered sample as follows, Fine gravel with trace coarse sand (9\%) and coarse gravel (13\%), poorly graded gravel is angular to subangular, composed mainly of igneous rocks, color is moderate yellowishbrown. 
Appendix 1. Compilation of borehole and aquifer data.-Continued

[cm, centimeter; $\mathrm{m}$, meter; in, inch; ft, feet; \%, percent; ppm, parts per million; $\approx$, approximately equal to; $>$, greater than]

\begin{tabular}{|c|c|c|c|c|}
\hline Bore & $\begin{array}{l}\text { Top } \\
\text { (m) }\end{array}$ & $\begin{array}{c}\text { Bottom } \\
\text { (m) }\end{array}$ & Simplified lithology & Driller's description \\
\hline Mark Group 402 & 12.50 & 19.57 & sand, clay and gravel & $\begin{array}{l}\text { Sand gravel with trace silt, sand } 33 \% \text {, gravel } 62 \% \text {, fines } \\
5 \% \text {, well graded, light brown to moderate yellowish- } \\
\text { brown, damp. Bulk sample at } 63.5 \mathrm{ft} \text {. Drove } 7 \text { in with } \\
174 \text { blows,. }\end{array}$ \\
\hline Mark Group 402 & 22.86 & 37.64 & sand and gravel & $\begin{array}{l}\text { Bulk sample at } 83 \mathrm{ft} \text {, met with refusal, unable to hold } \\
\text { sample in bulk sampler. Bottom of hole at } 83.5 \mathrm{ft} \text { on } \\
5 / 7 / 88 \text {. Started drilling from } 83.5 \mathrm{ft} \text { (open hole drill- } \\
\text { ing) Gravel and sand, } \approx 50 / 50 \text {, gravel is fine, and mostly } \\
\text { angular to subangular, clast. }\end{array}$ \\
\hline Mark Group 402 & 37.64 & 43.74 & sand, clay and gravel & $\begin{array}{l}\text { Start at depth of } 124.8 \mathrm{ft} \text { Undisturbed sample at } 124.8 \mathrm{ft} \text {, } \\
\text { drove } 81 / 2 \text { in with } 450 \text { blows. Sand with gravel, well } \\
\text { graded overall, sand with highest percent in the coarse } \\
\text { sand range. Gravel mostly fine, subangular average size } \\
\text { is } 1 / 8-1 / 4 \text { in, minor silt with clay, color is moderate } \\
\text { yellowish-brown, sample is slightly damp. }\end{array}$ \\
\hline
\end{tabular}

Mark Group 402

43.74

49.83

sand, clay and gravel

Mark Group 402B

0.00

11.43

sand and gravel

Mark Group 402C

0.00

1.83

sand, clay and trace gravel

Mark Group 402C

1.83

7.62

sand and gravel

Mark Group 402C

7.62

8.84

sand and gravel

Mark Group 402C

8.84
Bulk sample at $143.5 \mathrm{ft}$, drove 4 in with 300 blows. Net with refusal after 4 in. Sandy gravel with chips of boulder-size rocks composed mostly of igneous materials, well graded, reddish brown and light gray. Zone of thin reddish-brown clayey lenses 145-146 ft. Boulders with minor sand and silt 156-158 ft. At $162-163.5 \mathrm{ft}$, sand and fine gravel, minor clay. Boring abandoned due to drilling problems. Total depth of boring $163.5 \mathrm{ft}$.

Top of hole (ground level). Sand and gravel, sand is well graded, gravel size is unknown as drill cuttings are pulverized by action of under reamer and down hole hammer. Boring abandoned due to drilling problems. Total depth of boring $37.5 \mathrm{ft}$.

Gravelly sand with trace silt, well graded, light brown, slightly moist, no cementation, contains roots.

Very fine-grained sand with some medium to coarse sand and gravel, well graded, light brown, dry, no cementation.

Sandy gravel with trace cobble, well graded, grayishbrown, dry, no cementation.

Gravelly sand with trace silt, well graded, light brown, dry, no cementation. 
Appendix 1. Compilation of borehole and aquifer data.-Continued

[cm, centimeter; m, meter; in, inch; ft, feet; \%, percent; ppm, parts per million; $\approx$, approximately equal to; $>$, greater than]

\begin{tabular}{|c|c|c|c|c|}
\hline Bore & $\begin{array}{l}\text { Top } \\
\text { (m) }\end{array}$ & $\begin{array}{l}\text { Bottom } \\
\text { (m) }\end{array}$ & Simplified lithology & Driller's description \\
\hline Mark Group 402C & 9.14 & 10.06 & sand, clay and gravel & $\begin{array}{l}\text { Sandy gravel with trace cobble, well graded, grayish- } \\
\text { brown, dry, no cementation. At } 33 \mathrm{ft} \text {, gravelly sand with } \\
\text { trace silt, well graded, light brown, dry, no cementation. } \\
\text { Bottom of hole at } 40 \mathrm{ft} \text {. }\end{array}$ \\
\hline Mark Group 402C & 16.76 & 21.34 & sand and gravel & $\begin{array}{l}\text { Gravel and sand, gravel about } 60 \% \text { well graded, mostly } \\
\text { medium to coarse, slightly damp, color is moderate } \\
\text { yellowish-brown. }\end{array}$ \\
\hline Mark Group 402C & 21.34 & 22.86 & sand and gravel & $\begin{array}{l}\text { Sand and gravel, sand } 70 \% \text {, large coarse fraction but well } \\
\text { graded, gravel } 30 \% \text { is fine. }\end{array}$ \\
\hline Mark Group 402C & 22.86 & 24.38 & sand and gravel & $\begin{array}{l}\text { Gravel and sand, gravel } 80 \% \text { is fine, sand } 20 \% \text {, color is } \\
\text { pale yellowish-brown. }\end{array}$ \\
\hline Mark Group 402C & 24.38 & 29.26 & sand, clay and gravel & $\begin{array}{l}\text { Bulk sample at } 80 \mathrm{ft} \text {, down } 9 \text { in with } 150 \text { blows. Sandy } \\
\text { gravel with trace of silt, } 40 \% \text { sand, } 55 \% \text { gravel, and } \\
5 \% \text { fines, well graded, gravel is fine with rocks that are } \\
\text { mostly subangular, color is pale yellowish-brown. }\end{array}$ \\
\hline Mark Group 402C & 35.05 & 36.58 & sand and gravel & Sand and gravel $50 / 50$. Bottom of hole at 120 on $5 / 16 / 88$. \\
\hline Mark Group 402C & 36.58 & 39.01 & sand and gravel & $\begin{array}{l}\text { Started drilling from } 120 \mathrm{ft} \text {, gravel and sand, sand mostly } \\
\text { coarse to medium } 40 \% \text { gravel mostly fine } 60 \% \text {, color is } \\
\text { pale yellowish brown. At } 127-128 \mathrm{ft} \text { same except sand } \\
\text { about } 50 \% \text { gravel } 50 \% \text {, color is light brown). }\end{array}$ \\
\hline Mark Group 402C & 39.01 & 42.06 & sand and gravel & $\begin{array}{l}\text { Same except gravel is about } 40 \% \text {, coarse to medium sand } \\
\text { is } 60 \% \text {. }\end{array}$ \\
\hline Mark Group 402C & 42.06 & 42.67 & sand and gravel & Sand $80 \%$ with gravel $20 \%$, light brown, slightly damp. \\
\hline Mark Group 402C & 42.67 & 44.50 & sand and gravel & $\begin{array}{l}\text { Sand and gravel, about 50/50 sand is well graded, gravel } \\
\text { is fine. }\end{array}$ \\
\hline
\end{tabular}


Appendix 1. Compilation of borehole and aquifer data.-Continued

[cm, centimeter; $\mathrm{m}$, meter; in, inch; ft, feet; \%, percent; ppm, parts per million; $\approx$, approximately equal to; >, greater than]

\begin{tabular}{ccccc}
\hline Bore & $\begin{array}{c}\text { Top } \\
(\mathbf{m})\end{array}$ & $\begin{array}{c}\text { Bottom } \\
(\mathbf{m})\end{array}$ & Simplified lithology & Driller's description \\
\hline Mark Group 402C & 44.50 & 47.85 & sand and gravel & $\begin{array}{c}\text { Gravel and sand with gravel about } 60-70 \%, \text { sand } 40-30 \%, \\
\text { zone very hard and cemented gravel is multicolored } \\
\text { with various igneous rock types and sand is well graded, } \\
\text { color is pale yellowish brown. }\end{array}$ \\
& & &
\end{tabular}

Mark Group 402C

Mark Group 402C

48.77

50.90

sand, clay and gravel

Mark Group 402C

Mark Group 402C

52.12

53.04

sand and gravel

Mark Group 402C

53.04

54.86

sand and gravel

Mark Group 402C

53.04

60.96

sand and gravel

Mark Group 402C

60.96

61.33

sand and gravel

Mark Group 402C

61.33

67.06

sand and gravel
Sand and gravel, sand $60 \%$ gravel $40 \%$, color light brown and slightly damp.

Bulk sample at $160 \mathrm{ft}$, drove 7.2 in with 300 blows undisturbed sample $160.6 \mathrm{ft}$, drove 4.8 in with 280 blow. Sandy gravel with trace of silt and clay, subrounded rocks, sand $41 \%$ is well graded. Sample contains about $6 \%$ silt and clay and $53 \%$ gravel.

Gravel and sand about 50/50, gravel is fine and well graded, multi colored rocks.

Sand $60 \%$, gravel $40 \%$, sand is coarse to fine, $173-174 \mathrm{ft}$ hard zone, cemented gravel.

sand $70 \%$, fine gravel $30 \%, 178-180 \mathrm{ft}$ same, but largest gravel is about $3 / 4$ in diameter. Bottom of hole at $180 \mathrm{ft}$ on $5 / 17 / 88$.

Started drilling from $180 \mathrm{ft}$. Bulk sample at $180 \mathrm{ft}$, drove 5 in with 150 blows. Sample contains, Gravel with trace of sand (14\%) poorly graded, gravel $80 \%$, sand fine to medium $20 \%$, gravel subrounded, light gray. Sand fraction may have been lost. Sand 70\% and fine gravel 30\%, sand is well graded, and gravel is angular to subrounded, color is moderate brown and slightly damp. At 190$199 \mathrm{ft}$ sand $80 \%$, gravel 20\%, well graded. At $198 \mathrm{ft}$ minor red clay. At 199-200 ft gravel fraction increased to about $30 \%$. Undisturbed sample at $200 \mathrm{ft}$, drove $9 / 5$ in with 150 blows. Bulk sample at $200.8 \mathrm{ft}$, drove 6 in with 150 blows.

Gravel with sand (28\%) and trace of clay (8\%) well graded.

Gravel (60-70\%) and sand (40-30\% gravel as above, sand well graded with larger coarse fraction, no clay seen. Color is a pale yellowish brown. 208-213 ft as above, zone is hard with abundant basalt chips. Bottom of hole at $220 \mathrm{ft}$ on $5 / 18 / 88$. 
Appendix 1. Compilation of borehole and aquifer data.-Continued

[cm, centimeter; m, meter; in, inch; ft, feet; \%, percent; ppm, parts per million; $\approx$, approximately equal to; $>$, greater than]

\begin{tabular}{ccccc}
\hline Bore & $\begin{array}{c}\text { Top } \\
(\mathbf{m})\end{array}$ & $\begin{array}{c}\text { Bottom } \\
(\mathbf{m})\end{array}$ & Simplified lithology & Driller's description \\
\hline Mark Group 402C & 67.06 & 69.49 & sand, clay and gravel & $\begin{array}{c}\text { Started drilling from 220 ft. Bulk sample at 220 ft, drove } \\
7 \text { in with 150 blows. Sand with gravel }(22 \%) \text { and trace } \\
\text { of silt (10\%), light brown color, damp. 225-228 ft same } \\
\text { as above but drier. }\end{array}$ \\
& & &
\end{tabular}

\begin{tabular}{|c|c|c|c|c|}
\hline Mark Group 402C & 69.49 & 70.71 & sand and gravel & Fine gravel $70 \%$, sand $30 \%$, more cemented than before. \\
\hline Mark Group 402C & 70.71 & 71.32 & sand and gravel & Sand $60 \%$, gravel $40 \%$. \\
\hline Mark Group 402C & 71.32 & 73.15 & sand and gravel & Sand and gravel in about equal proportions. \\
\hline Mark Group 402C & 73.15 & 79.25 & sand, clay and gravel & $\begin{array}{l}\text { Bulk sample at } 240 \mathrm{ft} \text {, drove } 5 \text { in with } 150 \text { blows. Bulk } \\
\text { sample at } 240.4 \mathrm{ft} \text {, Refusal after } 5 \mathrm{in} \text {. At } 240 \mathrm{ft} \text { sandy } \\
\text { gravel with trace of silt and clay, well graded, at } 240.4 \mathrm{ft} \\
\text { sand } 35 \% \text {, gravel } 60 \% \text {, fines } 5 \% \text {. Sand } 75 \% \text { coarse to } \\
\text { fine, well graded and fine gravel } 25 \% \text {, light brown in } \\
\text { color, slightly damp. } 255-260 \mathrm{ft} \text { caved material was the } \\
\text { same as above. Formation caved in (will have to set } 6 \text { in } \\
\text { casing). End of Drilling at } 255 \mathrm{ft} \text { on } 5 / 19 / 88 \text {. Bottom of } \\
\text { hole and } 260 \mathrm{ft} \text { on } 5 / 19 / 88 \text {. }\end{array}$ \\
\hline
\end{tabular}

Mark Group 402C $\quad 79.25 \quad 82.84 \quad$ sand, clay and gravel

Started drilling from $260 \mathrm{ft}$. Bulk sample at $260 \mathrm{ft}$, drove 12 in with 150 blows. Gravelly sand with trace of silt, $40 \%$ gravel, $52 \%$ sand, $8 \%$ fines, well graded, slightly moist, minor silt content, gravel with up to golf ball size rocks. Bottom of hole at $271.8 \mathrm{ft}$, on 5/26/88. Note, 6 in casing set to $260 \mathrm{ft}$.

Mark Group 402C $\quad 82.84 \quad 84.73 \quad$ sand, clay and gravel

Mark Group 402C

84.73

86.26

sand, clay and gravel

Mark Group 402C

86.26

87.48

sand, clay and gravel
Started drilling from $271.8 \mathrm{ft}$. Bulk sample at $271 \mathrm{ft}$, drove 8 in with 150 blows undisturbed sample at $271.7 \mathrm{ft}$, drove 5 in with 150 blows. Sandy gravel with trace of silt, $45 \%$ sand, $50 \%$ gravel, $5 \%$ fines, well graded, light brown, slightly damp, gravel is fine, subrounded.

Bulk sample at $278 \mathrm{ft}$, drove $1.5 \mathrm{ft}$. Sand with gravel and trace silt, poorly graded (60\% sand, $28 \%$ gravel, $6 \%$ fines), sample is damp (not wet), color is moderate brown. Bottom of hole at $283 \mathrm{ft}$ on 5/27/88.

Depth to water $282.2 \mathrm{ft}$. Started drilling from $283 \mathrm{ft}$, gravelly sand with trace silt, well graded (36\% gravel, $56 \%$ sand, $8 \%$ fines) Bulk sample at $283 \mathrm{ft}$, drove 10 in with 150 blows. Undisturbed sample at $283.8 \mathrm{ft}$, drove 12 in with 150 blows.

Thin zone of clayey silty sand, light brown color. Bulk sample at $288 \mathrm{ft}$, drove $11 \mathrm{in}$. 
Appendix 1. Compilation of borehole and aquifer data.-Continued

[cm, centimeter; $\mathrm{m}$, meter; in, inch; ft, feet; \%, percent; ppm, parts per million; $\approx$, approximately equal to; >, greater than]

\begin{tabular}{|c|c|c|c|c|}
\hline Bore & $\begin{array}{l}\text { Top } \\
\text { (m) }\end{array}$ & $\begin{array}{c}\text { Bottom } \\
\text { (m) }\end{array}$ & Simplified lithology & Driller's description \\
\hline Mark Group 402C & 87.72 & 89.31 & sand, clay and gravel & $\begin{array}{l}\text { Clayey sand with silt and gravel, poorly graded ( } 39 \% \\
\text { fines, } 51 \% \text { sand, } 10 \% \text { gravel) Open hole drilling. Bot- } \\
\text { tom of hole at } 293 \mathrm{ft} \text { on } 5 / 28 / 88 \text {. Attached air hammer } \\
\text { above sampler. Unable to note blow counts as system } \\
\text { is extremely rapid. Depth to water } 283.3 \mathrm{ft} \text {, water } \\
\text { level measurement taken at } 07: 05 \text {. Bulk sample at } \\
293 \mathrm{ft} \text {, drove } 6 \text { in with } 20 \text { blows. Undisturbed sample } \\
\text { at } 293.5 \mathrm{ft} \text {, drove } 12 \text { in with } 56 \text { blows. At } 293 \mathrm{ft} \text {, silt, } \\
\text { highly cemented, very friable, crumbles easily, thinly } \\
\text { bedded, slightly damp (sweats in plastic bag) pale yel- } \\
\text { lowish brown color. Note, Driller attempted to drive } \\
\text { casing deeper than } 289.5 \mathrm{ft} \text { but met with refusal. Bottom } \\
\text { of hole at } 293 \mathrm{ft} \text { on } 6 / 1 / 88 \text {. }\end{array}$ \\
\hline
\end{tabular}

\begin{tabular}{|c|c|c|c|c|}
\hline Mark Group 402C & 89.31 & 90.22 & sand, clay and gravel & $\begin{array}{l}\text { Started drilling from } 293 \mathrm{ft} \text {. Note, bottom of casing at } \\
286.6 \mathrm{ft} \text { Open hole drilling. Same silt becoming more } \\
\text { sandy } 295-296 \mathrm{ft} \text {. }\end{array}$ \\
\hline Mark Group 402C & 90.22 & 93.88 & sand and clay & $\begin{array}{l}\text { Bulk sample at } 298 \mathrm{ft} \text {, recovered } 5 \text { in with } 50 \text { blows. Silty, } \\
\text { fine grain sand, weak, breaks easily, indistinct bedding, } \\
\text { wet, light brown color. At } 302 \mathrm{ft} \text { streaks of gravelly } \\
\text { sand. Bulk sample at } 303 \mathrm{ft} \text {, recovered } 5 \text { in with } 72 \\
\text { blows. } 303-308 \mathrm{ft} \text { sample, silty sand, poorly graded, } \\
\text { soft, pale yellowish brown in color. Bulk sample was dry } \\
\text { to only damp. Bulk sample at } 308 \mathrm{ft} \text {, drove } 12 \text { in with } \\
100 \text { blows. At } 308 \mathrm{ft} \text { clayey silty very-fine-grained sand, } \\
\text { poorly graded, very silty damp with vertical tubes filled } \\
\text { with kaolinite clay. Bottom of hole at } 309 \mathrm{ft} \text { on } 6 / 2 / 88 \text {. }\end{array}$ \\
\hline
\end{tabular}

Mark Group 402C $\quad 94.18 \quad 95.10 \quad$ sand and clay

Depth to water $\approx 292.8 \mathrm{ft}$. Started drilling from $309 \mathrm{ft}$. Note, Used down hole hammer mounted above sampler. clayey, silty fine-grained sandstone cemented with clay into while calcareous layer both firm and brittle. Bulk sample at $312 \mathrm{ft}$, drove 4 in with 130 blows. Undisturbed sample at $312.3 \mathrm{ft}$, drove 8.5 in with 150 blows.

\begin{tabular}{|c|c|c|c|c|}
\hline Mark Group 402C & 96.01 & 96.01 & sand and clay & $\begin{array}{l}\text { Same as above, except white layers are thing and interlaye } \\
\text { with sandy, clayey silt. }\end{array}$ \\
\hline Mark Group 402C & 96.01 & 97.23 & sand and clay & Same but softer containing more clay. \\
\hline Mark Group 402C & 97.23 & 98.15 & sand and clay & $\begin{array}{l}\text { Bulk sample at } 319 \mathrm{ft} \text {, drove } 5 \text { in. Clayey sand, fine grain, } \\
\text { hard to brittle, clay cement, light olive gray. }\end{array}$ \\
\hline Mark Group 402C & 98.15 & 99.06 & sand and clay & $\begin{array}{l}\text { Same but more clay Bulk sample at } 324 \mathrm{ft} \text {, drove } 4 \mathrm{in} \text {. At } \\
325 \mathrm{ft} \text {, same, sand very fine grain, as above, light gray } \\
\text { to light olive gray. Bulk sample at } 329 \mathrm{ft} \text {,. Bulk sample } \\
\text { at } 324 \mathrm{ft} \text {, recovered } 4 \mathrm{in} \text {. Undisturbed sample at } 324 \mathrm{ft} \text {. } \\
\text { Bottom of hole at } 334 \mathrm{ft} \text { on 6/3/88. }\end{array}$ \\
\hline
\end{tabular}


Appendix 1. Compilation of borehole and aquifer data.-Continued

[cm, centimeter; m, meter; in, inch; ft, feet; \%, percent; ppm, parts per million; $\approx$, approximately equal to; $>$, greater than]

\begin{tabular}{|c|c|c|c|c|}
\hline Bore & $\begin{array}{l}\text { Top } \\
\text { (m) }\end{array}$ & $\begin{array}{l}\text { Bottom } \\
(\mathrm{m})\end{array}$ & Simplified lithology & Driller's description \\
\hline Mark Group 402C & 99.06 & 102.57 & sand and clay & $\begin{array}{l}\text { Depth to water } 296.55 \mathrm{ft} \text {. Start open hole drilling from } \\
334 \mathrm{ft} \text {. Sand, very fine grain, as before. }\end{array}$ \\
\hline Mark Group 402C & 102.57 & 102.87 & clay, sand and limestone & Silt, white, very hard but brittle. \\
\hline Mark Group 402C & 103.33 & 103.54 & clay and sand & $\begin{array}{l}\text { Bulk sample at } 339 \mathrm{ft} \text {, drove } 4.5 \text { in with } 230 \text { blows. Clayey } \\
\text { silt, pale yellowish brown, soft to moderately hard. }\end{array}$ \\
\hline Mark Group 402C & 104.85 & 108.81 & sand and clay & $\begin{array}{l}\text { Silty fine-medium sand, well graded. Bulk sample at } \\
349 \mathrm{ft} \text {, drove } 5 \text { in } 180 \text { blows. }\end{array}$ \\
\hline Mark Group 402C & 108.81 & 109.12 & clay and sand & $\begin{array}{l}\text { Bulk sample at } 354 \mathrm{ft} \text {, drove } 7 \text { in } 200 \text { blows. Undisturbed } \\
\text { sample at } 354.6 \mathrm{ft} \text {, drove } 12 \text { in } 80 \text { blows. light brown } \\
\text { silt, moderately hard and brittle. }\end{array}$ \\
\hline Mark Group 402C & 109.73 & 111.86 & clay and sand & $\begin{array}{l}\text { Clayey silt with trace fine sand, tan, saturated (but only } \\
\text { appears moist in noncemented portions) no dry strength, } \\
\text { no plasticity, soft with white coarse sand to gravel size } \\
\text { altered grains that break across the grain. Bulk sample } \\
\text { at } 364 \mathrm{ft} \text {, recovered } 12 \text { in. At } 367 \mathrm{ft} \text { very fine sandy silt } \\
\text { with trace clay maximum particle size medium sand, } \\
\text { low dry strength, no plasticity, brown, saturated, weak } \\
\text { cementation to moderate cementation in gravel size } \\
\text { pieces. Starting to produce water. Bulk sample at } 369 \mathrm{ft} \text {, } \\
\text { recovered } 15 \text { in. Bulk sample at } 374 \mathrm{ft} \text {, recovered } 10 \mathrm{in} \text {. } \\
\text { Bottom of hole at } 374 \mathrm{ft} \text { on } 6 / 6 / 88 \text {. }\end{array}$ \\
\hline
\end{tabular}


Appendix 1. Compilation of borehole and aquifer data.-Continued

[cm, centimeter; $\mathrm{m}$, meter; in, inch; ft, feet; \%, percent; ppm, parts per million; $\approx$, approximately equal to; $>$, greater than]

\begin{tabular}{|c|c|c|c|c|}
\hline Bore & $\begin{array}{l}\text { Top } \\
\text { (m) }\end{array}$ & $\begin{array}{c}\text { Bottom } \\
\text { (m) }\end{array}$ & Simplified lithology & Driller's description \\
\hline Mark Group 402C & 111.86 & 115.98 & clay and sand & $\begin{array}{l}\text { Depth to water } 319.9 \mathrm{ft} \text {, started drilling from } 374 \mathrm{ft} \text {, very } \\
\text { fine sandy silt clay, low plasticity, no dry strength, } \\
\text { brown, saturated, weak cementation to moderate ce- } \\
\text { mentation in gravel sized pieces, } 378-378.5 \mathrm{ft} \text { stronger } \\
\text { cementation. }\end{array}$ \\
\hline Mark Group 402C & 116.74 & 117.35 & clay and sand & $\begin{array}{l}\text { Bulk sample at } 384 \mathrm{ft} \text {, recovered } 10 \text { in. Very fine sandy silt, } \\
\text { maximum particle size medium sand, low dry strength, } \\
\text { no plasticity, brown, saturated, platy fracture, moderate } \\
\text { cementation, weak reaction with acid. }\end{array}$ \\
\hline
\end{tabular}

Mark Group 402C $\quad 117.35 \quad 117.65 \quad$ clay and sand

Mark Group 402C $\quad 117.77 \quad 120.09 \quad$ clay and sand

Mark Group 402C $\quad 120.09 \quad 121.77 \quad$ sand and clay

Mark Group 402C $\quad 121.77 \quad 124.36 \quad$ sand, clay and gravel

Mark Group 402C $\quad 124.36 \quad 130.76 \quad$ sand, clay and gravel

Mark Group 403

3.96

sand and trace gravel
Silt fine to medium sand, well graded, brown, saturated, no cementation.

Very fine sandy silt, maximum particle size medium sand, very low dry strength, no plasticity, brown, saturated, platy fracture, moderate cementation, very weak reaction with acid. Bulk sample at $389 \mathrm{ft}$, recovered 9 in.

Silty fine-medium sand, well graded, brown, saturated, some weak cementation in gravel-sized masses $(<10 \%$ by volume), no reaction with acid. Bulk sample at $394 \mathrm{ft}$, recovered 13 in. Bulk/Undisturbed sample at $399 \mathrm{ft}$, recovered $11 \mathrm{in.} \mathrm{At} 399.5 \mathrm{ft}$ silty fine-medium sand with trace gravel, well graded, brown, saturated, no cementation. Bottom of hole at $399 \mathrm{ft}$, on 6/7/88.

Depth to water $322.7 \mathrm{ft}$. Started drilling from $399 \mathrm{ft}$, silty, fine-medium sand with trace coarse sand and gravel (to 1 in diameter), well graded, brown, saturated, no cementation. Bulk sample at $404 \mathrm{ft}$, recovered $12 \mathrm{in}$. Grades to coarser materials.

Bulk sample at $409 \mathrm{ft}$, recovered 9 in 2 tries. Cobble gravel with trace sand and silt, well graded, brown with colors of individual grains, saturated, no cementation. Rig chatter at $427-420 \mathrm{ft}$. At $429 \mathrm{ft}$ gravel with trace fine sand, silt, and cobble, poorly graded (gap graded), brown, saturated, no cementation. At $434 \mathrm{ft}$ more sand (finemedium) less silt. Rig chatter at $435 \mathrm{ft}$, cobbles. Hole caving above drill stem. Total depth of boring at $436 \mathrm{ft}$.

Gravelly, fine-medium sand with trace cobble, well graded, brown, dry, contains roots, no cementation. At $4 \mathrm{ft}$, slightly moist. At $8 \mathrm{ft}$, no more roots, color change to brown. 
Appendix 1. Compilation of borehole and aquifer data.-Continued

[cm, centimeter; $\mathrm{m}$, meter; in, inch; ft, feet; \%, percent; ppm, parts per million; $\approx$, approximately equal to; >, greater than]

\begin{tabular}{|c|c|c|c|c|}
\hline Bore & $\begin{array}{l}\text { Top } \\
(\mathrm{m})\end{array}$ & $\begin{array}{l}\text { Bottom } \\
(\mathrm{m})\end{array}$ & Simplified lithology & Driller's description \\
\hline Mark Group 403 & 3.96 & 5.18 & $\begin{array}{l}\text { sand, clay and trace } \\
\text { gravel }\end{array}$ & $\begin{array}{l}\text { Sand with trace travel, silt and cobble, well graded, light } \\
\text { brown, dry, no cementation. At } 15 \mathrm{ft} \text { same with color } \\
\text { change to brown, slightly moist. }\end{array}$ \\
\hline Mark Group 403 & 5.18 & 5.49 & sand and trace gravel & $\begin{array}{l}\text { Fine to medium sand with trace gravel and cobble }(\approx 25 \% \\
\text { G\&C), gap graded, brown, slightly moist. }\end{array}$ \\
\hline Mark Group 403 & 5.49 & 8.84 & sand, clay and gravel & $\begin{array}{l}\text { Bulk sample at } 18 \mathrm{ft} \text {, recovered } 11 \text { in } 2 \text { attempts. Gravelly } \\
\text { sand with trace cobble and silt, well graded, light brown, } \\
\text { dry, no cementation } 20 \mathrm{ft} \text {, slightly moist at } 20 \mathrm{ft} \text {. }\end{array}$ \\
\hline Mark Group 403 & 10.06 & 13.11 & $\begin{array}{l}\text { sand, clay and trace } \\
\text { gravel }\end{array}$ & $\begin{array}{l}\text { Gravelly sand with trace cobble and silt, well graded, } \\
\text { light brown, dry, no cementation. Bulk sample at } 38 \mathrm{ft} \text {, } \\
\text { recovered } 15 \text { in. }\end{array}$ \\
\hline Mark Group 403 & 13.11 & 13.72 & sand and gravel & $\begin{array}{l}\text { Sandy gravel, well graded, light brown, dry, no } \\
\text { cementation. }\end{array}$ \\
\hline Mark Group 403 & 13.72 & 14.63 & sand and gravel & $\begin{array}{l}\text { Gravelly sand ( } \approx 60 \% \text { sand, } 40 \% \text { gravel) with trace cobble, } \\
\text { well graded, light brown, dry, no cementation. }\end{array}$ \\
\hline Mark Group 403 & 16.76 & 20.73 & sand, clay and gravel & $\begin{array}{l}\text { Sand with some gravel }(\approx 20 \%) \text { and trace silt, well graded, } \\
\text { brown, slightly moist, no cementation. Bulk/undisturbed } \\
\text { sample at } 58 \mathrm{ft} \text {, recovered } 18 \mathrm{in} \text {. At } 65 \mathrm{ft} \text { same with more } \\
\text { gravel and trace cobble. }\end{array}$ \\
\hline
\end{tabular}

Mark Group 403

20.73

27.13

sand and trace gravel

Mark Group 403

Mark Group 403
27.13

27.74

sand and gravel

28.96
27.74 sand, clay and trace gravel
Gravelly sand with trace cobble, well graded, brown, dry, no cementation. Bulk/undisturbed sample at $78 \mathrm{ft}$, recovered 14 in. At $80 \mathrm{ft}$ same, slightly moist. Rig chatter 82-82.5 ft, large cobbles.

Sandy gravel with some cobble, well graded, $(\approx 35 \%$ sand, $45 \%$ gravel, $20 \%$ cobble) brown, dry, no cementation.

Gravelly sand with trace cobble sand clay, well graded, reddish-brown, slightly moist, no cementation. 
Appendix 1. Compilation of borehole and aquifer data.-Continued

[cm, centimeter; $\mathrm{m}$, meter; in, inch; ft, feet; \%, percent; ppm, parts per million; $\approx$, approximately equal to; >, greater than]

\begin{tabular}{ccccc}
\hline Bore & $\begin{array}{c}\text { Top } \\
(\mathbf{m})\end{array}$ & $\begin{array}{c}\text { Bottom } \\
(\mathbf{m})\end{array}$ & Simplified lithology & Driller's description \\
\hline Mark Group 403 & 28.96 & 29.26 & sand, clay and gravel & $\begin{array}{c}\text { Sandy gravel with some cobble, well graded, grayish- } \\
\text { brown, dry, no cementation. At } 96 \mathrm{ft} \text { sand with some } \\
\text { gravel and trace silt (clay and cobble, well graded, } \\
\text { reddish-brown, slightly moist, no cementation. Bulk } \\
\end{array}$ \\
& & & $\begin{array}{l}\text { sample at } 98 \mathrm{ft} \text {, recovered } 12 \text { in. Bottom of hole at } 98 \mathrm{ft} \\
\text { on } 6 / 22 / 88 .\end{array}$
\end{tabular}

Mark Group 403

Mark Group 403

Mark Group 403

Mark Group 403

Mark Group 403

Mark Group 403

Mark Group 403

Mark Group 403
29.26

32.00

sand, clay and gravel

32.00

38.10

sand, clay and gravel

38.10

43.89

sand, clay and gravel

$43.89 \quad 44.50 \quad$ sand and gravel

$44.50 \quad 46.94 \quad$ sand, clay and gravel

$46.94 \quad 55.47 \quad$ sand, clay and gravel

$55.47 \quad 57.61 \quad$ sand and trace gravel

57.61

58.83

sand, clay and trace gravel
Started Drilling from $98 \mathrm{ft}$, sand with trace gravel, clay, and cobble, well graded, reddish brown, slightly moist, not cementation. at $101 \mathrm{ft}$ same with color change to brown, dry.

Sand with gravel and trace clay and cobble, well graded, reddish brown, slightly moist, no cementation. Bulk/ undisturbed sample at $118 \mathrm{ft}$, recovered $24 \mathrm{in}$.

Sandy gravel with trace cobble and clay, well graded, brown, dry, no cementation. At 125-127 ft rig chatter. At $129-131 \mathrm{ft}$ rig chatter. At $133 \mathrm{ft}$, same but slightly moist. At $135-138 \mathrm{ft}$, rig chatter. Bulk sample at $138 \mathrm{ft}$, recovered 9 in.

Gravelly sand with cobble (gravel 30 30/sand 50/ cobble 20 ), well graded, brown, slightly moist, no cementation.

Sand with gravel and trace silt and cobble, well graded, brown slightly moist, no cementation. At $154 \mathrm{ft}$ sandy gravel with cobble and trace clay, well graded, reddish brown, slightly moist, no cementation. Bottom of hole at $158 \mathrm{ft}$ on $6 / 23 / 88$.

Started drilling from $158 \mathrm{ft}$, sandy gravel with some cobble and trace clay, well graded, reddish, brown slightly moist, no cementation, very dense, moderately cohesive due to clay. At $163 \mathrm{ft}$ same but not as much clay. At $172 \mathrm{ft}$. More clay (20\%), color change to brown. Bulk sample at $178 \mathrm{ft}$, recovered 13 in.

Fine to medium sand with some coarse sand and gravel and trace cobble, well graded, slightly moist, brown, no cementation.

Gravelly sand with some clay ( $\approx 15 \%)$, well graded, brown, slightly moist, rig chatter throughout this strata. 
Appendix 1. Compilation of borehole and aquifer data.-Continued

[cm, centimeter; m, meter; in, inch; ft, feet; \%, percent; ppm, parts per million; $\approx$, approximately equal to; $>$, greater than]

\begin{tabular}{ccccc}
\hline Bore & $\begin{array}{c}\text { Top } \\
(\mathbf{m})\end{array}$ & $\begin{array}{c}\text { Bottom } \\
(\mathbf{m})\end{array}$ & Simplified lithology & Driller's description \\
\hline Mark Group 403 & 58.83 & 59.44 & sand, clay and gravel & $\begin{array}{c}\text { Fine to medium sand with gravel, gap graded, brown, dry, } \\
\text { no cementation. At 195 ft. Sandy gravel with cobble and } \\
\text { clay, well graded, brown, slightly moist, no cementa- } \\
\text { tion. Caving stopped driving down at 195 ft. Bulk/ } \\
\text { undisturbed sample at } 199 \mathrm{ft}, \text { recovered } 18 \mathrm{in} . \text { Bottom of } \\
\text { hole at } 199 \mathrm{ft} \text { on } 6 / 24 / 88 .\end{array}$ \\
& & &
\end{tabular}

Mark Group 403

Mark Group 403

Mark Group 403

Mark Group 403

Mark Group 403

Mark Group 403

Mark Group 403

Mark Group 403

Mark Group 403

73.15

62.94

63.40

65.23

68.58

69.49

71.63
62.18

sand, clay and gravel
62.94

sand, clay and gravel

68.58

sand, clay and gravel

sand and trace gravel

71.63

sand, clay and gravel

73.15

sand, clay and gravel

77.72

sand, clay and gravel
77.72

84.73
Started drilling from $199 \mathrm{ft}$, sandy gravel with cobble and trace clay $(\approx 10 \%)$ well graded, brown, slightly moist, no cementation. At $210 \mathrm{ft}$ rig chatter casing driving hard for all $20 \mathrm{ft}$.

Sandy gravel with cobble and trace clay $(30 \% / 40 / 20 \% / 10 \%)$, well graded, black, slightly moist.

Cobble gravel with trace sand, well graded, slightly moist, rig chatter throughout.

Sand with gravel $(\approx 20 \%)$ and clay $(\approx 15 \%)$, well graded, brown, slightly moist, no cementation.

Sandy gravel with clay and trace cobble, well graded, reddish brown, slightly moist, no cementation. Bulk sample at $218 \mathrm{ft}$, recovered $9 \mathrm{in}$.

Gravelly sand with cobble ( $\approx 20 \%)$, well graded, brown, slightly moist, no cementation.

Sand with gravel $(\approx 20 \%)$ and trace clay $(\approx 15 \%)$, well graded, reddish brown, slightly moist, no cementation.

Gravelly sand with cobble and trace clay, well graded, brown, slightly moist, no cementation. Bulk/undisturbed sample at $238 \mathrm{ft}$, recovered $18 \mathrm{in}$.

Sand with gravel and clay $(\approx 20 \%)$ and trace cobble, well graded brown, slightly moist, no cementation. Casing driving very slowly, but continues to go down. At $255 \mathrm{ft}$, fine to medium sand with some silt and trace gravel $(\approx 15 \%)$ and cobble $(\approx 5 \%)$, well graded, brown, slightly moist, no cementation. Bottom of hole at $258 \mathrm{ft}$, on 6/25/88.

Started drilling from $258 \mathrm{ft}$. Bulk sample at $258 \mathrm{ft}$, recovered 9 in. Fine to medium sand with some silt and trace gravel $(\approx 15 \%$ ) and cobble $(\approx 5 \%)$, well graded, brown, slightly moist, no cementation. 
Appendix 1. Compilation of borehole and aquifer data.-Continued

[cm, centimeter; $\mathrm{m}$, meter; in, inch; ft, feet; \%, percent; ppm, parts per million; $\approx$, approximately equal to; >, greater than]

\begin{tabular}{|c|c|c|c|c|}
\hline Bore & $\begin{array}{l}\text { Top } \\
\text { (m) }\end{array}$ & $\begin{array}{l}\text { Bottom } \\
(\mathrm{m})\end{array}$ & Simplified lithology & Driller's description \\
\hline Mark Group 403 & 84.73 & 85.04 & sand & $\begin{array}{l}\text { Bulk/Undisturbed sample at } 379 \mathrm{ft} \text {, recovered } 16 \text { in. Fine } \\
\text { to medium sand, poorly graded, brown, slightly moist, } \\
\text { no cementation. }\end{array}$ \\
\hline Mark Group 403 & 85.04 & 85.19 & sand and gravel & $\begin{array}{l}\text { Sand with gravel, well graded, brown, moist, no } \\
\text { cementation. }\end{array}$ \\
\hline Mark Group 403 & 85.19 & 85.95 & sand and gravel & $\begin{array}{l}\text { Fine to medium sand with gravel, very poorly graded, } \\
\text { brown, slightly moist, no cementation. }\end{array}$ \\
\hline Mark Group 403 & 85.95 & 86.41 & sand and clay & $\begin{array}{l}\text { Clayey sand, poorly graded, brown, moist, no cementation. } \\
\text { Bulk sample at } 282 \mathrm{ft} \text {, recovered } 16 \mathrm{in} \text {. }\end{array}$ \\
\hline Mark Group 403 & 87.17 & 87.78 & clay and sand & $\begin{array}{l}\text { Clayey very fine sand, weak plastic thread, brown, wet, } \\
\text { medium stiff, no cementation. Bulk sample at } 288 \mathrm{ft} \text {, } \\
\text { recovered } 9 \text { in. }\end{array}$ \\
\hline Mark Group 403 & 87.78 & 90.22 & $\begin{array}{l}\text { sand, clay and trace } \\
\text { gravel }\end{array}$ & $\begin{array}{l}\text { Gravelly sand with silt, well graded, brown, slightly moist, } \\
\text { no cementation. Bulk sample at } 293 \mathrm{ft} \text {, recovered } 8 \text { in. }\end{array}$ \\
\hline Mark Group 403 & 91.14 & 92.51 & $\begin{array}{l}\text { clay, sand and trace } \\
\text { gravel }\end{array}$ & $\begin{array}{l}\text { Fine-grained sandy clay, maximum particle size fine } \\
\text { gravel, medium dry strength, moderate plasticity, brown, } \\
\text { wet stiff with some moderate cementation in large } \\
\text { gravel-size masses. }\end{array}$ \\
\hline Mark Group 403 & 92.51 & 92.66 & sand, clay and gravel & $\begin{array}{l}\text { Sand with gravel and trace silt, well graded, brown satu- } \\
\text { rated, no cementation. At } 304 \mathrm{ft} \text {, fine-grained sandy silt } \\
\text { with gravel }(\approx 30 \%) \text {, low dry strength, low plasticity, } \\
\text { brown, saturated. Bulk sample at } 303 \mathrm{ft} \text {, recovered } 14 \mathrm{in} \text {. } \\
\text { Undisturbed sample at } 304 \mathrm{ft} \text {, recovered } 18 \text { in. Bottom } \\
\text { of hole at } 303 \mathrm{ft} \text {, on } 6 / 28 / 88 \text {. Depth to water measured at } \\
300.9 \mathrm{ft} \text { from ground surface. Depth of water } 300.92 \mathrm{ft} \text {. } \\
\text { Started drilling from } 303 \mathrm{ft} \text {. }\end{array}$ \\
\hline
\end{tabular}


Appendix 1. Compilation of borehole and aquifer data.-Continued

[cm, centimeter; m, meter; in, inch; ft, feet; \%, percent; ppm, parts per million; $\approx$, approximately equal to; $>$, greater than]

\begin{tabular}{|c|c|c|c|c|}
\hline Bore & $\begin{array}{l}\text { Top } \\
\text { (m) }\end{array}$ & $\begin{array}{c}\text { Bottom } \\
\text { (m) }\end{array}$ & Simplified lithology & Driller's description \\
\hline Mark Group 403 & 93.27 & 94.03 & sand, clay and gravel & $\begin{array}{l}\text { Sand with gravel and trace clay, well graded, brown, satu- } \\
\text { rated, occasional strong cementation in coarse gravel- } \\
\text { sized masses. Bulk sample at } 308 \mathrm{ft} \text {, recovered } 10 \text { in. }\end{array}$ \\
\hline Mark Group 403 & 94.03 & 94.49 & clay, sand and gravel & $\begin{array}{l}\text { Fine-grained sandy silt with trace clay, maximum particle } \\
\text { size fine gravel }(<3 \%) \text {, low dry strength, no plasticity, } \\
\text { brown, moist, no cementation. }\end{array}$ \\
\hline Mark Group 403 & 94.49 & 96.62 & sand and clay & $\begin{array}{l}\text { Sand with trace silt }(\approx 15 \%) \text { and gravel }(\approx 10 \%) \text {, well } \\
\text { graded, brown, saturated, loose, no cementation. Bulk } \\
\text { sample at } 314 \mathrm{ft} \text {, recovered } 3 \text { in, may have lost part of } \\
\text { fines. At } 317 \mathrm{ft} \text { silty, fine-grained sand, poorly graded, } \\
\text { light brown, saturated, moderate cementation. Bottom of } \\
\text { hole at } 319 \mathrm{ft} \text { on } 6 / 29 / 88 \text {. }\end{array}$ \\
\hline Mark Group 403 & 96.62 & 97.38 & sand and clay & $\begin{array}{l}\text { Depth to water } 310.5 \mathrm{ft} \text {. Started drilling from } 319 \mathrm{ft} \text {. Silty, } \\
\text { fine-grained sand, poorly graded, light brown, saturated, } \\
\text { moderate cementation, medium dry strength with very } \\
\text { minor (localized) reactions to acid. Bulk/undisturbed } \\
\text { sample at } 319 \mathrm{ft} \text {, recovered } 13 \mathrm{in} .\end{array}$ \\
\hline Mark Group 403 & 97.23 & 102.72 & clay and sand & $\begin{array}{l}\text { Fine-grained sandy silt, maximum particle size medium } \\
\text { sand, medium dry strength, no plasticity, light brown, } \\
\text { saturated, alternating thin layers of firm with no cemen- } \\
\text { tation and hard with moderate cementation and platy } \\
\text { fracture. Bulk sample at } 324 \mathrm{ft} \text {, recovered } 11 \text { in. Bulk } \\
\text { sample at } 329 \mathrm{ft} \text {, recovered } 18 \text { in. Bulk sample at } 334 \mathrm{ft} \text {, } \\
\text { recovered } 11 \mathrm{in} \text {. At } 335 \mathrm{ft} \text { contains trace quartz gravel } \\
(\approx 5 \%) .\end{array}$ \\
\hline Mark Group 403 & 103.63 & 104.55 & clay and sand & $\begin{array}{l}\text { Very fine-grained sandy silt, maximum particle size } \\
\text { medium sand, medium dry strength, no plasticity, light } \\
\text { brown, saturated, moderately strong cementation. }\end{array}$ \\
\hline Mark Group 403 & 104.55 & 105.77 & clay and sand & $\begin{array}{l}\text { Silt with trace fine sand and clay, maximum particle size } \\
\text { medium sand, low-medium dry strength, no plasticity, } \\
\text { light brown, saturated, no cementation with gravel-sized } \\
\text { moderately cemented masses, very mild reaction with } \\
\text { acid. Undisturbed sample at } 344 \mathrm{ft} \text {, recovered } 16 \text { in. } \\
\text { Bulk sample at } 346 \mathrm{ft} \text {, recovered } 18 \mathrm{in} \text {. At } 347 \mathrm{ft} \text { silty } \\
\text { fine-grained sand, poorly graded, light brown, saturated, } \\
\text { moderate-strong cementation. Bottom of hole at } 349 \mathrm{ft} \\
\text { on } 6 / 30 / 88 \text {. }\end{array}$ \\
\hline
\end{tabular}


Appendix 1. Compilation of borehole and aquifer data.-Continued

[cm, centimeter; $\mathrm{m}$, meter; in, inch; ft, feet; \%, percent; ppm, parts per million; $\approx$, approximately equal to; >, greater than]

\begin{tabular}{|c|c|c|c|c|}
\hline Bore & $\begin{array}{l}\text { Top } \\
\text { (m) }\end{array}$ & $\begin{array}{l}\text { Bottom } \\
\text { (m) }\end{array}$ & Simplified lithology & Driller's description \\
\hline Mark Group 403 & 106.38 & 106.68 & clay and sand & $\begin{array}{l}\text { Depth to water } 318.72 \mathrm{ft} \text {. Started drilling from } 349 \mathrm{ft} \text {, sand } \\
\text { fine to medium grain, weakly cemented. Bulk sample } \\
\text { B403-29-349, recovered } 13 \text { in. }\end{array}$ \\
\hline Mark Group 403 & 106.71 & 107.90 & sand and gravel & $\begin{array}{l}\text { Sand well graded, fine to medium weakly cemented, } \\
\text { observed several white quartz pebbles, hit some clay at } \\
353-354 \mathrm{ft} \text {. Bulk sample B403-30-354, recovered } 15 \text { in. }\end{array}$ \\
\hline Mark Group 403 & 107.90 & 108.81 & sand & $\begin{array}{l}\text { Sand fine grain, light moderate brown color, weakly } \\
\text { cemented. }\end{array}$ \\
\hline
\end{tabular}

Mark Group 403

Mark Group 403

Mark Group 403

Mark Group 403

112.99

114.00

clay

Mark Group 403

114.00

114.91 sand, clay and trace
gravel

Mark Group 403

114.91

115.21

sand, clay and trace gravel

Mark Group 403

117.04

clay and sand
Silty-sandy light brown clay damp but not moist, dense material. Bulk sample B403-31-359, recovered 18 in. Bulk sample B403-32-364, recovered 12 in.

Very fine-grained sand, weakly cemented, clayey with minor fine to medium grain sand.

Bulk sample B403-33-369. Silty clay, light brown, minor sand, dense.

clay, light olive gray, dry to only slightly damp, no silt or sand seen. At $374 \mathrm{ft}$ silty clayey sand. undisturbed U403-34-374, recovered 18 in. Bulk B403-34-374, recovered $9 \mathrm{in}$. Bottom of hole at $374 \mathrm{ft}$ on 7/1/88.

Depth to water $319.24 \mathrm{ft}$. Started drilling from $374 \mathrm{ft}$, silty clayey sand with trace gravel and sand, maximum particle size fine gravel, slight plasticity, light brown, saturated with trace organic material.

Silty sand with trace gravel, poorly graded, light brown, saturated with trace organic material.

Bulk sample at $379 \mathrm{ft}$, recovered 18 in. silty clay with trace fine sand, maximum particle size medium sand, no plasticity to medium plasticity when wet, light brown, saturated (but appears moist) with trace organic materials, low dry strength, swells with water addition. Bulk/ undisturbed sample at $384 \mathrm{ft}$, recovered $18 \mathrm{in}$. Bulk sample at $386 \mathrm{ft}$, recovered $18 \mathrm{in}$. 
Appendix 1. Compilation of borehole and aquifer data.-Continued

[cm, centimeter; m, meter; in, inch; ft, feet; \%, percent; ppm, parts per million; $\approx$, approximately equal to; $>$, greater than]

\begin{tabular}{|c|c|c|c|c|}
\hline Bore & $\begin{array}{l}\text { Top } \\
\text { (m) }\end{array}$ & $\begin{array}{c}\text { Bottom } \\
\text { (m) }\end{array}$ & Simplified lithology & Driller's description \\
\hline Mark Group 403 & 117.04 & 119.18 & sand and clay & $\begin{array}{l}\text { Silty fine-medium sand with trace clay, poorly graded } \\
\text { brown, saturated, no cementation. Bulk sample at } 389 \mathrm{ft} \text {, } \\
\text { recovered } 16 \mathrm{in} \text {. At } 391 \mathrm{ft} \text { silty clay with trace fine sand, } \\
\text { low dry strength, low plasticity, brown, saturated with } \\
\text { gravel-sized masses of high dry strength. Bulk sample } \\
\text { at } 394 \mathrm{ft} \text {, recovered } 18 \mathrm{in} \text {. Bottom of hole at } 394 \mathrm{ft} \text { on } \\
7 / 6 / 88 \text {. }\end{array}$ \\
\hline
\end{tabular}

Mark Group $403 \quad 119.18 \quad 125.12 \quad$ clay and sand

Mark Group 403

$125.12 \quad 126.19$

clay, sand and gravel

Mark Group 403

126.19

127.10

sand, clay and gravel

Mark Group 403

127.10

131.06

sand, clay and gravel

Mark Group 403

131.06

132.59

sand and gravel

Mark Group 403

132.59

133.50

sand and gravel
Depth to water $320.59 \mathrm{ft}$. Started drilling from $394 \mathrm{ft}$, silty clay with trace fine sand, low dry strength with gravelsized masses of high dry strength, low plasticity, brown, saturated. At 397-398 ft same with trace fine to coarse gravel, $\approx 10 \%$. At $398 \mathrm{ft}$ same as above at 391 without gravel with medium plasticity and weak reaction with acid. Bulk sample at $399 \mathrm{ft}$, recovered 18 in. Bulk/undisturbed sample at $404 \mathrm{ft}$, recovered 18 in. Bulk sample at $406 \mathrm{ft}$, recovered $18 \mathrm{in}$. At $404.5 \mathrm{ft}$ color changed to light brown, less sand. Bulk sample at $409 \mathrm{ft}$, recovered 18 in.

Gravelly clay, gap graded, maximum particle size coarse gravel, medium dry strength, medium plasticity, light brown, saturated, no cementation. Bulk sample at $414 \mathrm{ft}$, recovered $18 \mathrm{in}$.

Sandy clayey silt, maximum particle size coarse sand $(<2 \%)$, low dry strength with large gravel sized masses of high dry strength clay, no plasticity, brown, saturated, no cementation. At $417 \mathrm{ft}$, gravelly sand with trace silt, well graded, brown saturated, no cementation. Producing water. Bulk sample at $419 \mathrm{ft}$, recovered $10 \mathrm{in}$. Bottom of hole at $419 \mathrm{ft}$ on 7/7/88. Depth to water $323.35 \mathrm{ft}$.

Started drilling from $419 \mathrm{ft}$, gravelly sand with trace silt, clay and cobbles, well graded, brown, with colors of individual grains, saturated (producing water), no cementation. Bulk sample at $424 \mathrm{ft}$, recovered $\approx 10$ in. sample not representative, fines and sands washed out. At $425 \mathrm{ft}$ same as above with less fines. At 425-426 ft rig chatter.

Sandy gravel with cobble (large cobble), $(\approx 30 \%$ sand $/ 50 \%$ gravel $/ 20 \%$ cobble), well graded, brown, with colors of individual grains, saturated, no cementation (rig chatter throughout).

Gravelly sand with cobble and trace fines $(\approx 15 \%$ fines, well graded, light brown, saturated, no cementation. Casing would not drive beyond $436 \mathrm{ft}$. 
Appendix 1. Compilation of borehole and aquifer data.-Continued

[cm, centimeter; $\mathrm{m}$, meter; in, inch; ft, feet; \%, percent; ppm, parts per million; $\approx$, approximately equal to; >, greater than]

\begin{tabular}{ccccc}
\hline Bore & $\begin{array}{c}\text { Top } \\
(\mathbf{m})\end{array}$ & $\begin{array}{c}\text { Bottom } \\
(\mathbf{m})\end{array}$ & Simplified lithology & Driller's description \\
\hline Mark Group 403 & 133.50 & 137.77 & sand and gravel & $\begin{array}{c}\text { Cobble gravel with sand }(30 \% \text { cobble } / 50 \% \text { gravel } / 20 \% \\
\text { sand) well graded, brown with colors of individual } \\
\text { grains, saturated, no cementation. Large cobbles } \\
\text { throughout this zone, colors of cuttings change depend- } \\
\text { ing upon the individual cobble/boulder, considerable rig } \\
\text { chatter. }\end{array}$ \\
& & &
\end{tabular}

Mark Group 403

Mark Group 403

Mark Group 403

Mark Group 403

Mark Group 403

Mark Group 403

156.67

159.41

sand and trace gravel

Mark Group 403

Mark Group 403

Mark Group 403

Mark Group 403

174.65

179.83

sand and gravel

Mark Group 403

sand, clay and trace gravel

Gravel

sand and gravel

sand and gravel

sand and gravel

$159.41 \quad 174.65 \quad$ sand and gravel

$163.07 \quad 164.29 \quad$ sand and gravel

$165.20 \quad 167.34 \quad$ sand and gravel
Rig chatter (large cobbles). Bottom of hole at $562 \mathrm{ft}$ on $7 / 8 / 88$.

Cobble gravel with trace sand, well graded, colors of individual grains, saturated, no cementation. At $573-578 \mathrm{ft}$ rig chatter.

Sandy gravel with trace silt (5\%), well graded, light brown with colors of individual grains, saturated, no cementation. 
Appendix 1. Compilation of borehole and aquifer data.-Continued

[cm, centimeter; m, meter; in, inch; ft, feet; \%, percent; ppm, parts per million; $\approx$, approximately equal to; $>$, greater than]

\begin{tabular}{|c|c|c|c|c|}
\hline Bore & $\begin{array}{l}\text { Top } \\
\text { (m) }\end{array}$ & $\begin{array}{c}\text { Bottom } \\
\text { (m) }\end{array}$ & Simplified lithology & Driller's description \\
\hline Mark Group 403 & 180.75 & 181.36 & sand, clay and gravel & Considerable rig chatter. \\
\hline Mark Group 403 & 181.36 & 190.80 & sand, clay and gravel & $\begin{array}{l}\text { Cobble gravel with trace sand, well graded, colors of indi- } \\
\text { vidual grains, saturated, no cementation. At } 601 \mathrm{ft} \text { same } \\
\text { with trace silt. At } 612-614 \mathrm{ft} \text { considerable rig chatter. } \\
\text { At } 626 \mathrm{ft} \text {. Cobble gravel with boulders and trace sand } \\
(5 \%) \text { well graded, colors of individual grains, saturated, } \\
\text { no cementation. Considerable rig chatter from } 626 \mathrm{ft} \\
\text { on down. Considerable rig chatter from } 626 \mathrm{ft} \text { on down } \\
\text { (especially at } 637 \mathrm{ft} \text { ). Total depth of boring at } 658 \mathrm{ft} \text {. }\end{array}$ \\
\hline
\end{tabular}

Perc Est AFCA1

0.00

0.49

sand and trace gravel

Perc Est AFCA1

Perc Est AFCA1

Perc Est AFCA1

Perc Est AFCA1

Perc Est AFCA1

Perc Est AFCA1

3.11

Perc Est AFCA1

Perc Est AFCA1
1.40

4.08

clay and sand

4.08

5.03

clay, sand and trace gravel

0.61

sand and gravel

sand and gravel

sand and trace gravel

sand and trace gravel

clay and sand

$5.03 \quad 5.35 \quad$ sand and clay
Sand, fine, moist, windblown, and occasional volcanic gravel and cobbles embedded in sand, moderate yellowish brown (10YR5/4). Gravel and cobbles commonly coated with calcite.

Boulders and cobbles mixed with sand, dry.

Pavement of cobbles and boulders.

Sand and gravel, mostly sand, gravel as large as $4 \mathrm{~cm}$, roots around cobbles, fewer roots at 0.9 meter, grayish orange pink (5YR7/2).

Sand with few stones, fine, powdery, very dry. Cored $1.07-2.59 \mathrm{~m}$, recovered $33 \mathrm{~cm}$ of sample.

Silt with fine sand, partly cemented, occasional fine gravel and coarse sand, pinkish gray (5YR8/1). Cored 2.59-3.20 m, recovered $52 \mathrm{~cm}$.

Silt with fine sand, partly cemented, dry very pale orange (10YR8/2). Cored 3.20-4.11 m, recovered $88 \mathrm{~cm}$.

Silt with fine sand, compacted, dry, very pale orange $(10 \mathrm{YR} 8 / 2)$. Roots with oxidization rings are throughout core. Many dark colored pebbles embedded in sandy silt. Bottom $15 \mathrm{~cm}$ has more sand. Overall look is like marl. Cored 4.11-5.03 m, recovered $92 \mathrm{~cm}$.

Sand, medium to fine-grained, dry 5.03-5.18 m, very pale orange (10YR8/2). Grades-fine sand and silt $5.18-5.33 \mathrm{~m}$. Silt is dense and cemented with fossilized roots-almost a siltstone. Cored 5.03-5.58 m, recovered $30 \mathrm{~cm}$. 
Appendix 1. Compilation of borehole and aquifer data.-Continued

[cm, centimeter; $\mathrm{m}$, meter; in, inch; ft, feet; \%, percent; ppm, parts per million; $\approx$, approximately equal to; $>$, greater than]

\begin{tabular}{ccccc}
\hline Bore & $\begin{array}{c}\text { Top } \\
(\mathbf{m})\end{array}$ & $\begin{array}{c}\text { Bottom } \\
(\mathbf{m})\end{array}$ & Simplified lithology & Driller's description \\
\hline Perc Est AFCA1 & 5.35 & 6.55 & clay and sand & $\begin{array}{c}\text { Silt with fine sand, dense and partly cemented, almost a } \\
\text { siltstone, very pale orange }(10 Y R 8 / 2) . \text { Sample is mottled } \\
\text { with grayish green sandy silt and contains many nearly } \\
\text { vertical streaks of yellow orange oxidation with fossil- } \\
\end{array}$ \\
& & & ized roots. Calcite nodules are present and seem to have \\
& & formed around old root traces or in small 26 burrows. & Cored $5.58-6.55$ m, recovered $97 \mathrm{~cm}$.
\end{tabular}

$\begin{array}{llll}\text { Perc Est AFCA1 } & 6.55 & 7.16 \quad \text { clay and sand }\end{array}$

Perc Est AFCA1

7.16

8.23

clay and sand

Perc Est AFCA1

8.23

8.30

sand and gravel

8.30

8.69

Perc Est AFCA1

Perc Est AFCA1

8.69

9.14

sand and gravel

Perc Est AFCA1

Perc Est AFCA1

10.21

10.68

clay, sand and trace gravel

Perc Est AFCA1

10.68

11.89

sand and gravel

11.89

13.20

sand

Perc Est AFCA1

13.20

14.20

sand

14.20

$14.51 \quad$ sand

Perc Est AFCA1
Perc Est AFCA1

Silt with fine sand, dense and partly cemented, almost a siltstone, very pale orange (10YR8/2). There are fewer zones of oxidation and fossilized roots. Cored $6.55-7.16 \mathrm{~m}$, recovered $61 \mathrm{~cm}$.

Silt with fine sand, dense and partly cemented 7.16-8.23 m, almost a siltstone, very pale orange (10YR8/2). There are only occasional zones of oxidation. Black pebbles at $8.23 \mathrm{~m}$. Cored 7.16-8.69 m, recovered $1.52 \mathrm{~m}$.

Sand and gravel, gravel as large as $6.3 \mathrm{~mm}$, loose and dry.

Sand, coarse, loose and slightly damp. Sand is mottled gray, brown, black and pink.

Sand and gravel with gravel a dark red volcanic rock, cemented. Cored 8.69-9.14 m, recovered $30 \mathrm{~cm}$. Cored again and collected $15 \mathrm{~cm}$ of sample, called it 8.99-9.14 m.

No core, drilled hard 9.14-9.60 m, easy 9.60-9.75 m, hard again $9.75-10.21 \mathrm{~m}$.

Silt with sand, minor gravel, dry and partly cemented. No fossilized roots, oxidation, or calcite nodules observed. Cored 10.21-11.73 m, recovered $42 \mathrm{~cm}$.

Sand and gravel with some cobbles, coarse sand, dry and loose. Stones commonly quartzite and carbonate. Cored $11.73-12.65 \mathrm{~m}$, recovered $15 \mathrm{~cm}$.

Sand, coarse, well sorted for entire core. Individual grains are gray, brown, pink and black. Cored 12.65-13.26 m, recovered $53 \mathrm{~cm}$.

Sand, fine-coarse. Cored 13.26-14.20 m, recovered $64 \mathrm{~cm}$.
Sand, coarse, well sorted, gravelly at $14.48 \mathrm{~m}$. Cored 14.20-14.941 m, recovered $30 \mathrm{~cm}$. End of hole. 
Appendix 1. Compilation of borehole and aquifer data.-Continued

[cm, centimeter; $\mathrm{m}$, meter; in, inch; ft, feet; \%, percent; ppm, parts per million; $\approx$, approximately equal to; >, greater than]

\begin{tabular}{|c|c|c|c|c|}
\hline Bore & $\begin{array}{l}\text { Top } \\
\text { (m) }\end{array}$ & $\begin{array}{l}\text { Bottom } \\
\text { (m) }\end{array}$ & Simplified lithology & Driller's description \\
\hline Perc Est AFCA2 & 0.00 & 0.34 & $\begin{array}{l}\text { clay, sand and trace } \\
\text { gravel }\end{array}$ & $\begin{array}{l}\text { Silt with fine sand and some gravel, numerous roots, moist, } \\
\text { dark yellowish brown (10YR4/2). Sandy silt is wind- } \\
\text { blown. }\end{array}$ \\
\hline Perc Est AFCA2 & 0.34 & 0.88 & sand, clay and gravel & $\begin{array}{l}\text { Sand and gravel, gravel as large as } 61 \mathrm{~cm} \text {, mostly volcanic, } \\
\text { one large stone of obsidian, some roots, loose, and damp } \\
\text { but not as moist as overlying sandy silt, grayish orange } \\
\text { pink (5YR7/2). }\end{array}$ \\
\hline Perc Est AFCA2 & 0.88 & 1.22 & $\begin{array}{l}\text { clay, sand and trace } \\
\text { gravel }\end{array}$ & $\begin{array}{l}\text { Silt with minor gravel, some clay and roots, minor oxida- } \\
\text { tion, damp, grayish orange pink }(5 \mathrm{YR} 7 / 2) \text {. Cored } \\
1.07-1.98 \mathrm{~m} \text {, recovered } 61 \mathrm{~cm} \text {. }\end{array}$ \\
\hline Perc Est AFCA2 & 1.68 & 2.13 & sand and clay & $\begin{array}{l}\text { Sand with silt, no roots or oxidation observed, moist, gray- } \\
\text { ish orange pink }(5 \mathrm{YR} 7 / 2) \text {. Cored } 1.98-2.59 \mathrm{~m} \text {, recov- } \\
\text { ered } 61 \mathrm{~cm} \text {. }\end{array}$ \\
\hline Perc Est AFCA2 & 2.13 & 2.59 & clay and sand & $\begin{array}{l}\text { Silt with sand, pea-size gravel at } 2.56 \mathrm{~m} \text {, moist yet readily } \\
\text { falls apart, grayish orange pink }(5 \mathrm{YR} 7 / 2) .\end{array}$ \\
\hline Perc Est AFCA2 & 2.59 & 2.96 & sand and gravel & $\begin{array}{l}\text { Sand and gravel, stones } 6 \mathrm{~mm} \text {, damp, grayish orange pink } \\
(5 \mathrm{YR} 7 / 2) \text {. Cored } 2.59-3.44 \mathrm{~m} \text {, recovered } 37 \mathrm{~cm} \text {. Driller } \\
\text { noted gravel at } 3.35 \mathrm{~m} .\end{array}$ \\
\hline Perc Est AFCA2 & 3.65 & 4.11 & clay and sand & $\begin{array}{l}\text { Silt with fine sand, partly cemented, mottled with oxida- } \\
\text { tion and manganese nodules, moist, grayish orange pink } \\
(5 \mathrm{YR} 7 / 2) \text {. }\end{array}$ \\
\hline Perc Est AFCA2 & 4.11 & 4.72 & sand and trace gravel & $\begin{array}{l}\text { Sand, fine-medium gravelly } 4.57-4.72 \mathrm{~m} \text {, moist, light } \\
\text { brown (5YR5/4). Cored 4.11-5.64 m, recovered } 152 \mathrm{~cm} \text {. }\end{array}$ \\
\hline Perc Est AFCA2 & 4.72 & 5.18 & sand and trace gravel & $\begin{array}{l}\text { Sand, medium to coarse, an occasional pebble, streaks of } \\
\text { bright yellow orange oxidation, moist, grayish orange } \\
(10 \mathrm{YR} 7 / 4) \text {. }\end{array}$ \\
\hline Perc Est AFCA2 & 5.18 & 5.64 & sand & Sand, fine, well sorted, moist, grayish orange (10YR7/4). \\
\hline Perc Est AFCA2 & 5.64 & 6.04 & sand & $\begin{array}{l}\text { Sand, medium-coarse, no pebbles, well sorted, moist, gray- } \\
\text { ish orange (10YR5/4). Cored 5.64-7.16 m, recovered } \\
152 \mathrm{~cm} .\end{array}$ \\
\hline
\end{tabular}


Appendix 1. Compilation of borehole and aquifer data.-Continued

[cm, centimeter; $\mathrm{m}$, meter; in, inch; ft, feet; \%, percent; ppm, parts per million; $\approx$, approximately equal to; >, greater than]

\begin{tabular}{ccccc}
\hline Bore & $\begin{array}{c}\text { Top } \\
(\mathbf{m})\end{array}$ & $\begin{array}{c}\text { Bottom } \\
(\mathbf{m})\end{array}$ & Simplified lithology & Driller's description \\
\hline Perc Est AFCA2 & 6.04 & 7.16 & clay and sand & $\begin{array}{c}\text { Silt with fine sand, streaks of bright yellow orange oxida- } \\
\text { tion, very pale orange }(10 Y R 8 / 2) .\end{array}$ \\
Perc Est AFCA2 & 7.16 & 8.08 & $\begin{array}{c}\text { clay, sand and trace } \\
\text { gravel }\end{array}$ & $\begin{array}{c}\text { Silt with fine sand, an occasional pebble, partly cemented, } \\
\text { vertical traces of faintly oxidized zones, some relic } \\
\text { root hairs and traces of light gray calcite along old } \\
\text { root traces, moist, very pale orange }(10 Y R 8 / 2) . \text { Cored } \\
7.16-8.08 \text { m, recovered } 91 \mathrm{~cm} .\end{array}$
\end{tabular}

Perc Est AFCA2 $\quad 8.08 \quad 8.23 \quad$ clay and sand

Perc Est AFCA2

Perc Est AFCA2

Perc Est AFCA2

9.24

10.15

sand and trace gravel

Perc Est AFCA2

Perc Est AFCA2

10.52

11.58

sand and trace gravel

Perc Est AFCA2

11.58

11.73

sand and trace gravel

Perc Est AFCA2

11.73

12.03

sand and trace gravel

Perc Est AFCA3

0.00

0.40

sand and clay

Perc Est AFCA3
0.40

1.00

sand, clay and trace gravel
Silt with fine sand (similar to preceding core), moist, very pale orange (10YR8/2). Cored 8.08-8.78 m, recovered $70 \mathrm{~cm}$.

Sand, fine to medium an occasional pebble, moist, yellowish gray $(5 \mathrm{Y} 7 / 2)$.

Sand, fine-medium gravelly 9.02-9.24 m, moist, yellowish gray (5Y7/2). Cored $8.78-10.21 \mathrm{~m}$, recovered $137 \mathrm{~cm}$.

Sand, coarse, and gravel, gravel as large as $5 \mathrm{~cm}$ and more abundant near 10.06 m, moist, pale red (10YR6/2).

Sand, coarse, and gravel, gravel as large as $4 \mathrm{~cm}$, thin layers of moisture, pale red (10R6/2). Cored 10.21-11. $13 \mathrm{~m}$, recovered $31 \mathrm{~cm}$, sediment at bottom of shoe on core was cemented and hard.

Sand, fine-medium with an occasional pebble, well sorted, damp, moderate yellowish brown (10YR5/4). Cored from $11,13-11.73 \mathrm{~m}$, recovered $60 \mathrm{~cm}$.

Sand, coarse, and gravel, gravel as large as $4 \mathrm{~cm}$, moist, pale red $(10 \mathrm{R} 5 / 2)$.

Sand, coarse, and gravel, gravel as large as $3 \mathrm{~cm}$, thin zones of moisture between drier sediments, pale red (10R5/2). Cored 11.73-12.65 m, recovered $30 \mathrm{~cm}$. Last meter was in sand and gravel. Drilling difficult.

Sand, fine with silt, numerous roots, moist, pale yellowish brown (10YR6/2).

Sand, fine with silt, pebbles common near 0.98 meter, numerous roots and drier than at surface, grayish orange pink (5YR7/2). 
Appendix 1. Compilation of borehole and aquifer data.-Continued

[cm, centimeter; $\mathrm{m}$, meter; in, inch; ft, feet; \%, percent; ppm, parts per million; $\approx$, approximately equal to; >, greater than]

\begin{tabular}{|c|c|c|c|c|}
\hline Bore & $\begin{array}{l}\text { Top } \\
\text { (m) }\end{array}$ & $\begin{array}{l}\text { Bottom } \\
(\mathrm{m})\end{array}$ & Simplified lithology & Driller's description \\
\hline Perc Est AFCA3 & 1.00 & 1.16 & $\begin{array}{l}\text { sand, clay and trace } \\
\text { gravel }\end{array}$ & $\begin{array}{l}\text { Sand and silt with pebbly gravel, loose and much less } \\
\text { moisture than near surface, grayish orange pink } \\
(5 \mathrm{YR} 7 / 2) . \text { Cored } 1.07-1.98 \mathrm{~m} \text {, recovered } 76 \mathrm{~cm} \text {. }\end{array}$ \\
\hline Perc Est AFCA3 & 1.16 & 1.83 & sand & $\begin{array}{l}\text { Sand, medium to fine, well sorted with only an occasional } \\
\text { root, more moisture than at } 1.16 \mathrm{~m} \text {, grayish orange pink } \\
(5 \mathrm{YR} 7 / 2) \text {. }\end{array}$ \\
\hline Perc Est AFCA3 & 1.83 & 2.56 & sand and clay & $\begin{array}{l}\text { Sand and silt, well sorted, minor amount of coarse sand, } \\
\text { moist, partly cemented with web-like secondary calcite } \\
\text { and root hairs at } 2.29 \mathrm{~m} \text {, grayish orange pink (5YR7/2). } \\
\text { Cored } 1.98-2.59 \mathrm{~m} \text {, recovered } 58 \mathrm{~cm} \text {. }\end{array}$ \\
\hline Perc Est AFCA3 & 3.11 & 4.02 & sand, clay and gravel & $\begin{array}{l}\text { Sand and gravel with some silt, gravel as large as } 3 \mathrm{~cm} \text {, } \\
\text { partly cemented, several roots with oxidation around } \\
\text { roots, damp, pale yellowish brown (10YR6/2). }\end{array}$ \\
\hline Perc Est AFCA3 & 4.02 & 4.42 & $\begin{array}{l}\text { sand, clay and trace } \\
\text { gravel }\end{array}$ & $\begin{array}{l}\text { Sand and silt with few pebbles, no roots, moist, moder- } \\
\text { ate yellowish brown (10YR5/4). Cored 4.11-5.64 m, } \\
\text { recovered } 122 \mathrm{~cm} .\end{array}$ \\
\hline Perc Est AFCA3 & 5.33 & 5.79 & sand and trace gravel & $\begin{array}{l}\text { Sand, medium to coarse, and gravel, gravel as large as } \\
1 \mathrm{~cm} \text {, moist, grayish orange pink }(5 \mathrm{YR} 7 / 2) \text {. Cored } \\
5.64-6.55 \mathrm{~m} \text {, recovered } 76 \mathrm{~cm} \text {. }\end{array}$ \\
\hline Perc Est AFCA3 & 5.79 & 6.40 & sand & $\begin{array}{l}\text { Sand, fine to medium well sorted, no roots or oxidation, } \\
\text { moist, grayish orange pink (5YR7/2). }\end{array}$ \\
\hline Perc Est AFCA3 & 6.40 & 7.07 & sand and trace gravel & $\begin{array}{l}\text { Sand, medium-coarse, well sorted, occasional pebble, no } \\
\text { roots or oxidation, moist, grayish orange pink (5YR7/2). } \\
\text { Cored } 6.55-7.16 \mathrm{~m} \text {, recovered } 61 \mathrm{~cm} \text {. }\end{array}$ \\
\hline Perc Est AFCA3 & 7.07 & 7.16 & sand and clay & $\begin{array}{l}\text { Silt and fine sand with rust colored blobs (weathering } \\
\text { around pebbles?), compact, some calcite webbing, } \\
\text { moist, grayish orange pink (5YR7/2). }\end{array}$ \\
\hline
\end{tabular}


Appendix 1. Compilation of borehole and aquifer data.-Continued

[cm, centimeter; $\mathrm{m}$, meter; in, inch; ft, feet; \%, percent; ppm, parts per million; $\approx$, approximately equal to; $>$, greater than]

\begin{tabular}{|c|c|c|c|c|}
\hline Bore & $\begin{array}{l}\text { Top } \\
\text { (m) }\end{array}$ & $\begin{array}{l}\text { Bottom } \\
(\mathrm{m})\end{array}$ & Simplified lithology & Driller's description \\
\hline Perc Est AFCA3 & 7.16 & 8.08 & $\begin{array}{l}\text { clay, sand and trace } \\
\text { gravel }\end{array}$ & $\begin{array}{l}\text { Silt and fine sand, occasional dark red to black pebbles, } \\
\text { some staining of grayish yellow ( } 5 \text { Y } 8 / 4) \text { that may be } \\
\text { relic oxidation, calcite nodules, partly cemented, moist, } \\
\text { yellowish gray (5YR7/2). Higher content of fine sand } \\
7.17-7.47 \mathrm{~m} \text {. Cored } 7.16 \text { to } 8.08 \mathrm{~m} \text {, recovered } 91 \mathrm{~cm} \text {. }\end{array}$ \\
\hline Perc Est AFCA3 & 8.08 & 8.66 & sand, clay and gravel & $\begin{array}{l}\text { Sand and gravel with silt, gravel as large as } 5 \mathrm{~cm} \text {, moist, } \\
\text { grayish orange pink }(5 \mathrm{YR} 7 / 2) . \text { Cored } 8.08-8.69 \mathrm{~m} \text {, } \\
\text { recovered } 58 \mathrm{~cm} .\end{array}$ \\
\hline Perc Est AFCA3 & 8.66 & 8.84 & sand and trace gravel & $\begin{array}{l}\text { Sand, coarse, and gravel, gravel as large as } 3 \mathrm{~cm} \text {, } \\
\text { loose, moist, grayish orange pink (5YR7/2). Cored } \\
8.69-10.21 \mathrm{~m} \text {, recovered } 122 \mathrm{~cm} .\end{array}$ \\
\hline Perc Est AFCA3 & 9.14 & 9.75 & sand and clay & $\begin{array}{l}\text { Silt with fine sand, compacted and partly cemented, occa- } \\
\text { sional calcite nodule, moist, grayish red (10R4/2). }\end{array}$ \\
\hline Perc Est AFCA3 & 9.75 & 9.91 & sand & Sand, fine to coarse, moist, grayish red (10R4/2). \\
\hline Perc Est AFCA3 & 9.91 & 10.82 & sand and clay & $\begin{array}{l}\text { Sand, fine, and silt with vertical calcite stringers, moist, } \\
\text { grayish red (10R4/2). Cored } 10.21-11.73 \mathrm{~m} \text {, recovered } \\
152 \mathrm{~cm} .\end{array}$ \\
\hline Perc Est AFCA3 & 11.73 & 13.26 & $\begin{array}{l}\text { sand, clay and trace } \\
\text { gravel }\end{array}$ & $\begin{array}{l}\text { Sand, fine, alternates with } 15-\mathrm{cm} \text { thick layers of silt } \\
\text { and fine sand, occasional pebbles, moist, grayish red } \\
(10 \mathrm{R} 4 / 2) . \text { Cored } 11.73-13.26 \mathrm{~m} \text {, recovered } 153 \mathrm{~cm} \text {. }\end{array}$ \\
\hline Perc Est AFCA3 & 13.26 & 13.44 & clay, sand and limestone & $\begin{array}{l}\text { Marl (?) with clay and silt, smears, gravel at } \\
13.41-13.44 \mathrm{~m} \text {, gravel as large as } 3 \mathrm{~cm} \text {, moist, very pale } \\
\text { orange }(10 \mathrm{YR} 8 / 2) \text {. Cored } 13.26-14.48 \mathrm{~m} \text {, recovered } \\
122 \mathrm{~cm} \text {. }\end{array}$ \\
\hline Perc Est AFCA3 & 13.44 & 13.62 & sand & $\begin{array}{l}\text { Sand, medium to coarse, well sorted, moist, dusky red } \\
(10 \mathrm{R} 3 / 2) \text {. Sand grains are red and black. }\end{array}$ \\
\hline Perc Est AFCA3 & 13.62 & 14.48 & sand & $\begin{array}{l}\text { Sand, fine to medium well sorted, one large white calcite } \\
\text { nodule, moist, grayish orange pink (5YR7/2). End of } \\
\text { hole. }\end{array}$ \\
\hline
\end{tabular}


Appendix 1. Compilation of borehole and aquifer data.-Continued

[cm, centimeter; $\mathrm{m}$, meter; in, inch; ft, feet; \%, percent; ppm, parts per million; $\approx$, approximately equal to; >, greater than]

\begin{tabular}{|c|c|c|c|c|}
\hline Bore & $\begin{array}{l}\text { Top } \\
(\mathrm{m})\end{array}$ & $\begin{array}{l}\text { Bottom } \\
(\mathrm{m})\end{array}$ & Simplified lithology & Driller's description \\
\hline Perc Est AFCA4 & 0.00 & 0.94 & $\begin{array}{l}\text { sand, clay and trace } \\
\text { gravel }\end{array}$ & $\begin{array}{l}\text { Sand, fine with silt and gravel, gravel as large as } 1 \mathrm{~cm} \text {, } \\
\text { numerous roots in uppermost } 60 \mathrm{~cm} \text {, moist, moderate } \\
\text { yellow brown }(10 \mathrm{YR} 5 / 4) \text {. Cored } 0.0-1.07 \mathrm{~m} \text {, recovered } \\
94 \mathrm{~cm} \text {. }\end{array}$ \\
\hline Perc Est AFCA4 & 1.37 & 1.68 & sand and trace gravel & $\begin{array}{l}\text { Sand, medium to coarse, minor gravel, occasional roots, } \\
\text { moist. }\end{array}$ \\
\hline Perc Est AFCA4 & 1.86 & 2.13 & sand and trace gravel & $\begin{array}{l}\text { Sand, coarse, and gravel, gravel as large as } 3 \mathrm{~cm} \text {, occasion- } \\
\text { al roots, moist. Cored } 1.98-2.59 \mathrm{~m} \text {, recovered } 61 \mathrm{~cm} \text {. }\end{array}$ \\
\hline Perc Est AFCA4 & 2.13 & 2.29 & sand & $\begin{array}{l}\text { Sand, medium to coarse, well sorted, occasional roots, } \\
\text { moist. }\end{array}$ \\
\hline Perc Est AFCA4 & 2.29 & 2.59 & clay and sand & $\begin{array}{l}\text { Silt with fine sand, numerous whitish root hairs and some } \\
\text { decomposing woody roots, moist, moderate brown } \\
(5 \mathrm{YR} 5 / 4) \text {. }\end{array}$ \\
\hline Perc Est AFCA4 & 3.90 & 3.96 & sand and clay & $\begin{array}{l}\text { Sand, fine, well sorted, layered with 6-12 mm thick yel- } \\
\text { lowish green silt and clay, moist. }\end{array}$ \\
\hline Perc Est AFCA4 & 3.96 & 4.87 & sand and trace gravel & $\begin{array}{l}\text { Sand, coarse, and gravel, gravel as large as } 1 \mathrm{~cm} \text {, less } \\
\text { gravel } 4.42-4.72 \mathrm{~m} \text {, no roots, moist. Cored } 4.11-4.94 \text {, } \\
\text { recovered } 76 \mathrm{~cm} .\end{array}$ \\
\hline Perc Est AFCA4 & 4.87 & 5.18 & sand and trace gravel & $\begin{array}{l}\text { Sand, fine with some gravel, gravel as large as } 2 \mathrm{~cm} \text {, moist. } \\
\text { Cored } 4.94-5.64 \text {, recovered } 70 \mathrm{~cm} \text {. }\end{array}$ \\
\hline Perc Est AFCA4 & 5.18 & 5.64 & sand and trace gravel & Sand, coarse, well sorted, occasional gravel to $3 \mathrm{~cm}$, moist. \\
\hline Perc Est AFCA4 & 5.64 & 6.49 & sand and trace gravel & $\begin{array}{l}\text { Sand, coarse, well sorted, occasional gravel, gravel as large } \\
\text { as } 1 \mathrm{~cm} \text {, no roots, moist. Cored } 5.64-6.55 \mathrm{~m} \text {, recovered } \\
85 \mathrm{~cm} \text {. }\end{array}$ \\
\hline
\end{tabular}


Appendix 1. Compilation of borehole and aquifer data.-Continued

[cm, centimeter; $\mathrm{m}$, meter; in, inch; ft, feet; \%, percent; ppm, parts per million; $\approx$, approximately equal to; >, greater than]

\begin{tabular}{ccccc}
\hline Bore & $\begin{array}{c}\text { Top } \\
(\mathbf{m})\end{array}$ & $\begin{array}{c}\text { Bottom } \\
(\mathbf{m})\end{array}$ & Simplified lithology & Driller's description \\
\hline Perc Est AFCA4 & 6.49 & 6.86 & sand and trace gravel & $\begin{array}{r}\text { Sand, coarse, and gravel, gravel as large as } 5 \mathrm{~cm}, \text { moist. } \\
\text { Cored } 6.55-7.16 \mathrm{~m}, \text { recovered } 61 \mathrm{~cm} .\end{array}$ \\
Perc Est AFCA4 & 6.86 & 7.16 & clay and sand & $\begin{array}{c}\text { Silt with fine sand, partly cemented, streaks of dark red } \\
\text { oxidation, no calcite or fossil roots observed, moist, } \\
\text { moderate brown }(5 Y R 5 / 4) .\end{array}$
\end{tabular}

Perc Est AFCA4

Perc Est AFCA4

Perc Est AFCA4

8.01

8.23

clay, sand and trace gravel

Silt with very fine sand, well sorted, pale yellowish brown (10YR6/2), layered with thin beds of medium gray (N6) calcite (freshwater limestone?) and one $5 \mathrm{~cm}$ thick layer of very light gray (N8) calcite.

Perc Est AFCA4 $8.44 \quad 8.68 \quad \begin{gathered}\text { clay, sand and trace } \\ \text { gravel }\end{gathered}$

Perc Est AFCA4

8.68

9.60

clay and sand

Perc Est AFCA4

9.60

9.85

clay and sand

Perc Est AFCA4

9.85

10.06

clay and sand

Perc Est AFCA5

0.00

0.9

sand and clay
Silt with very fine sand, an occasional pebble as large as $3 \mathrm{~mm}$, loose, zones of dark reddish brown oxidation, calcite stringers follow relic root traces, pale yellowish brown (10YR6/2).

Silt with very fine sand, thin layers of cemented siltstone, pale yellowish brown (10YR6/2). Cored 8.68-9.60 m, recovered $92 \mathrm{~cm}$.

Silt with very fine sand, thin layers of cemented siltstone, pale yellowish brown (10YR6/2) with minor yellowish oxidation streaks. Cored $9.60-9.85 \mathrm{~m}$, recovered $25 \mathrm{~cm}$. Stopped coring because could not penetrate cemented interval with core barrel.

Drilled slowly to $10.06 \mathrm{~m}$, drilling through something hard. Decided to stop drilling and move to another location. End of hole.

Sand, fine and silt, windblown, roots numerous to 0.46 meter, less common below, dry uppermost $6 \mathrm{~cm}$, moist below, moderate yellow brown (10YR5/4). Cored 0.0-1.07 $\mathrm{m}$, recovered everything except what was in shoe at end of core barrel.

Sand and gravel, gravel as large as $4 \mathrm{~cm}$, damp. 
Appendix 1. Compilation of borehole and aquifer data.-Continued

[cm, centimeter; $\mathrm{m}$, meter; in, inch; $\mathrm{ft}$, feet; \%, percent; ppm, parts per million; $\approx$, approximately equal to; >, greater than]

\begin{tabular}{|c|c|c|c|c|}
\hline Bore & $\begin{array}{l}\text { Top } \\
\text { (m) }\end{array}$ & $\begin{array}{l}\text { Bottom } \\
(\mathrm{m})\end{array}$ & Simplified lithology & Driller's description \\
\hline Perc Est AFCA5 & 1.07 & 1.40 & $\begin{array}{l}\text { sand, clay and trace } \\
\text { gravel }\end{array}$ & $\begin{array}{l}\text { Sand with silt and gravel, gravel decreases toward bottom, } \\
\text { no roots observed, considerably drier than above. Cored } \\
1.07-2.59 \mathrm{~m} \text {, recovered } 33 \mathrm{~cm} \text {. }\end{array}$ \\
\hline Perc Est AFCA5 & 1.40 & 3.02 & sand and trace gravel & $\begin{array}{l}\text { Sand, coarse, and gravel, gravel as large as } 1 \mathrm{~cm} \text {, } \\
\text { some roots, calcite veins in upper foot, moist. Cored } \\
2.59-3.51 \mathrm{~m} \text {, recovered } 49 \mathrm{~cm} \text {. }\end{array}$ \\
\hline Perc Est AFCA5 & 3.02 & 3.08 & clay and sand & $\begin{array}{l}\text { Silt with clay in layers }<6 \mathrm{~mm} \text { thick, very pale orange } \\
(10 \mathrm{YR} 8 / 2) \text {. }\end{array}$ \\
\hline Perc Est AFCA5 & 3.90 & 4.27 & sand and trace gravel & $\begin{array}{l}\text { Sand, coarse, and gravel, no roots, no calcite, loose, moist. } \\
\text { Cored 4.11-5.00 m, recovered } 89 \mathrm{~cm} \text {. }\end{array}$ \\
\hline Perc Est AFCA5 & 4.27 & 5.00 & sand and clay & $\begin{array}{l}\text { Sand, fine to medium with thin layers of cemented silt, } \\
\text { some veins of dark reddish oxidation near bottom of } \\
\text { interval. }\end{array}$ \\
\hline Perc Est AFCA5 & 5.00 & 5.64 & $\begin{array}{l}\text { sand, clay and trace } \\
\text { gravel }\end{array}$ & $\begin{array}{l}\text { Sand, fine with silt and an occasional pebble, calcite veins } \\
\text { prevalent } 5.33-5.64 \mathrm{~m} \text {, streaks of dark reddish brown } \\
\text { oxidation. Cored } 5.00-5.64 \mathrm{~m} \text {, recovered } 64 \mathrm{~cm} \text {. }\end{array}$ \\
\hline Perc Est AFCA5 & 6.85 & 6.95 & clay and sand & $\begin{array}{l}\text { Silt with clay, moist, highly mottled-grayish orange, bright } \\
\text { yellow orange, and dark reddish brown. }\end{array}$ \\
\hline Perc Est AFCA5 & 6.95 & 7.22 & clay and sand & $\begin{array}{l}\text { Silt with clay, highly mottled, similar to silt } 6.85-6.95 \mathrm{~m} \text {. } \\
\text { Cored } 7.16-8.69 \mathrm{~m} \text {, recovered } 143 \mathrm{~cm} \text {. }\end{array}$ \\
\hline Perc Est AFCA5 & 7.22 & 7.47 & sand & Sand, medium well sorted, abundant oxidation, moist. \\
\hline Perc Est AFCA5 & 7.47 & 8.38 & sand & $\begin{array}{l}\text { Sand, medium well sorted, minor oxidation and occasional } \\
\text { large calcite nodule, moist. }\end{array}$ \\
\hline Perc Est AFCA5 & 8.38 & 8.66 & sand & Sand, medium well sorted, loose, wet to touch. \\
\hline
\end{tabular}


Appendix 1. Compilation of borehole and aquifer data.-Continued

[cm, centimeter; $\mathrm{m}$, meter; in, inch; ft, feet; \%, percent; ppm, parts per million; $\approx$, approximately equal to; $>$, greater than]

\begin{tabular}{|c|c|c|c|c|}
\hline Bore & $\begin{array}{l}\text { Top } \\
\text { (m) }\end{array}$ & $\begin{array}{l}\text { Bottom } \\
\text { (m) }\end{array}$ & Simplified lithology & Driller's description \\
\hline Perc Est AFCA5 & 8.66 & 8.99 & sand & $\begin{array}{l}\text { Sand, medium well sorted, loose, wet-touch. Cored } \\
\text { 8.69-9.75 m, recovered } 104 \mathrm{~cm} \text {. }\end{array}$ \\
\hline Perc Est AFCA5 & 8.99 & 9.14 & clay and sand & Silt, wet to touch, yellowish gray (5Y7/2). \\
\hline Perc Est AFCA5 & 9.14 & 9.72 & clay, sand and limestone & $\begin{array}{l}\text { Silt, yellowish gray }(5 \mathrm{Y} 7 / 2) \text {, transitioning into mottled yel- } \\
\text { low gray and gray marl (?), wet. }\end{array}$ \\
\hline Perc Est AFCA5 & 9.72 & 10.06 & clay and sand & $\begin{array}{l}\text { Drilled into hard material, suspect material is a cemented } \\
\text { siltstone or marl. End of hole. }\end{array}$ \\
\hline Perc Est AFPL1 & 0.00 & 0.06 & sand and clay & $\begin{array}{l}\text { Sand, fine with silt and abundant organic matter, } \\
\text { moist, moderate yellowish brown (10YR5/4). Cored } \\
0.0-0.94 \text { meter, recovered } 94 \mathrm{~cm} .\end{array}$ \\
\hline Perc Est AFPL1 & 0.06 & 0.73 & $\begin{array}{l}\text { sand, clay and trace } \\
\text { gravel }\end{array}$ & $\begin{array}{l}\text { Sand, fine with silt and an occasional pebble, fewer roots } \\
\text { than at surface, drier, grayish orange }(10 \mathrm{YR} 5 / 4) \text {. }\end{array}$ \\
\hline Perc Est AFPL1 & 0.73 & 0.94 & $\begin{array}{l}\text { sand, clay and trace } \\
\text { gravel }\end{array}$ & $\begin{array}{l}\text { Sand, fine to coarse with silt and pebbles, pebbles more } \\
\text { common than above, pale yellowish brown }(10 \mathrm{YR} 6 / 2) \text {. }\end{array}$ \\
\hline Perc Est AFPL1 & 0.94 & 1.37 & $\begin{array}{l}\text { sand, clay and trace } \\
\text { gravel }\end{array}$ & $\begin{array}{l}\text { Drilled because too hard to core, cobble was in way of } \\
\text { coring. }\end{array}$ \\
\hline Perc Est AFPL1 & 1.37 & 1.98 & sand and trace gravel & $\begin{array}{l}\text { Sand, coarse, and gravel, gravel as large as } 4 \mathrm{~cm} \text {, no roots } \\
\text { or oxidation observed, moderate yellowish brown } \\
(10 \mathrm{YR} 5 / 4) . \text { Cored } 1.37-1.98 \mathrm{~m} \text {, recovered } 61 \mathrm{~cm} .\end{array}$ \\
\hline Perc Est AFPL1 & 1.98 & 2.53 & sand and clay & $\begin{array}{l}\text { Silt with fine sand, no roots, slightly cemented, moist, pale } \\
\text { yellowish brown }(10 \mathrm{YR} 6 / 2) \text {. Short oxidized staining } \\
\text { along fractures or old root traces. Calcite veins present } \\
\text { throughout silt. Cored } 1.98-2.59 \mathrm{~m} \text {, recovered } 61 \mathrm{~cm} \text {. }\end{array}$ \\
\hline Perc Est AFPL1 & 2.53 & 2.59 & sand and trace gravel & $\begin{array}{l}\text { Sand, coarse, and gravel, gravel as large as } 2 \mathrm{~cm} \text {, no roots, } \\
\text { loose, moist. }\end{array}$ \\
\hline Perc Est AFPL1 & 2.59 & 3.29 & sand and trace gravel & $\begin{array}{l}\text { Sand, coarse, and gravel, gravel as large as } 5 \mathrm{~cm} \text {, stones } \\
\text { often rounded, no roots, moist, pale yellowish brown } \\
(10 \mathrm{YR} 6 / 2) . \text { Cored } 2.59-3.51 \mathrm{~m} \text {, recovered } 70 \mathrm{~cm} \text {. }\end{array}$ \\
\hline Perc Est AFPL1 & 3.29 & 3.66 & sand and trace gravel & $\begin{array}{l}\text { Sand, coarse, and gravel, gravel as large as } 3 \mathrm{~cm} \text {, no roots, } \\
\text { moist, pale yellowish brown (10YR6/2). Cored } 3.5 \\
1-4.11 \mathrm{~m} \text {, recovered } 49 \mathrm{~cm} .\end{array}$ \\
\hline Perc Est AFPL1 & 3.66 & 3.93 & $\begin{array}{l}\text { clay, sand and trace } \\
\text { gravel }\end{array}$ & $\begin{array}{l}\text { Silt with fine sand and occasional pebble, no roots, moist, } \\
\text { moderate yellowish brown (10YR5/4). Several veins and } \\
\text { nodules of calcite, faint oxidation. }\end{array}$ \\
\hline
\end{tabular}


Appendix 1. Compilation of borehole and aquifer data.-Continued

[cm, centimeter; $\mathrm{m}$, meter; in, inch; ft, feet; \%, percent; ppm, parts per million; $\approx$, approximately equal to; >, greater than]

\begin{tabular}{|c|c|c|c|c|}
\hline Bore & $\begin{array}{l}\text { Top } \\
(\mathrm{m})\end{array}$ & $\begin{array}{l}\text { Bottom } \\
\text { (m) }\end{array}$ & Simplified lithology & Driller's description \\
\hline Perc Est AFPL1 & 3.93 & 4.00 & $\begin{array}{l}\text { clay, sand and trace } \\
\text { gravel }\end{array}$ & $\begin{array}{l}\text { Silt with sand and gravel, stones as large as } 3 \mathrm{~cm} \text {, no roots, } \\
\text { moist. }\end{array}$ \\
\hline Perc Est AFPL1 & 4.00 & 4.94 & $\begin{array}{l}\text { clay, sand and trace } \\
\text { gravel }\end{array}$ & $\begin{array}{l}\text { Silt and fine to medium sand, poorly sorted, occasional } \\
\text { gravel near top of interval, no roots, moist, moderate } \\
\text { yellowish brown }(10 \mathrm{YR} 5 / 4) \text {. Cored } 4.11-5.03 \mathrm{~m} \text {, recov- } \\
\text { ered } 82 \mathrm{~cm} .\end{array}$ \\
\hline Perc Est AFPL1 & 4.94 & 5.64 & sand and trace gravel & $\begin{array}{l}\text { Sand, coarse, and gravel, gravel as large as } 5 \mathrm{~cm} \text { com- } \\
\text { mon. Rusty-red stain around stones below } 5.49 \mathrm{~m} \text {, } \\
\text { moist, moderate yellowish brown (10YR5/4). Cored } \\
5.03-5.64 \mathrm{~m} \text {, recovered } 61 \mathrm{~cm} \text {. }\end{array}$ \\
\hline Perc Est AFPL1 & 5.72 & 6.46 & $\begin{array}{l}\text { sand, clay and trace } \\
\text { gravel }\end{array}$ & $\begin{array}{l}\text { Sand, fine and silt, occasional gravel as large as } 1 \mathrm{~cm} \text {, } \\
\text { moderate yellowish brown }(10 \mathrm{YR} 5 / 4) \text {. Calcite nodules } \\
\text { and veins common, no roots, moist, some oxidation. }\end{array}$ \\
\hline Perc Est AFPL1 & 6.46 & 6.71 & sand and clay & $\begin{array}{l}\text { Sand, fine, and silt, numerous calcite nodules, moist, mod- } \\
\text { erate yellowish brown (10YR5/4). Cored 6.46-7.16 m, } \\
\text { recovered } 70 \mathrm{~cm} \text {. }\end{array}$ \\
\hline Perc Est AFPL1 & 7.16 & 8.02 & $\begin{array}{l}\text { clay, sand and trace } \\
\text { gravel }\end{array}$ & $\begin{array}{l}\text { Silt and fine sand with occasional pebble, numerous calcite } \\
\text { nodules and thin calcified layers, moist, grayish orange } \\
\text { pink }(5 \text { YR7/2). Cored } 7.16-8.08 \mathrm{~m} \text {, recovered } 92 \mathrm{~cm} \text {. }\end{array}$ \\
\hline Perc Est AFPL1 & 8.02 & 8.08 & sand and clay & $\begin{array}{l}\text { Sand, fine, and silt, no noticeable calcite nodules, moist, } \\
\text { moderate yellowish brown (10YR5/4). }\end{array}$ \\
\hline Perc Est AFPL1 & 8.08 & 8.69 & $\begin{array}{l}\text { sand, clay and trace } \\
\text { gravel }\end{array}$ & $\begin{array}{l}\text { Sand, fine, occasional gravel as large as } 1 \mathrm{~cm} \text {, numerous } \\
\text { calcite nodules and veins, thin layers of partly cemented } \\
\text { silt, moist, moderate yellowish brown }(10 \mathrm{YR} 5 / 4) \text {. Cored } \\
8.08-8.69 \mathrm{~m} \text {, recovered } 61 \mathrm{~cm} \text {. }\end{array}$ \\
\hline Perc Est AFPL1 & 8.69 & 8.81 & sand & $\begin{array}{l}\text { Sand, fine, several calcite nodules and veins, moist, moder- } \\
\text { ate yellowish brown (10YR5/4). Cored } 8.69-9.57 \mathrm{~m} \text {, } \\
\text { recovered } 88 \mathrm{~cm} \text {. }\end{array}$ \\
\hline
\end{tabular}


Appendix 1. Compilation of borehole and aquifer data.-Continued

[cm, centimeter; $\mathrm{m}$, meter; in, inch; ft, feet; \%, percent; ppm, parts per million; $\approx$, approximately equal to; >, greater than]

\begin{tabular}{|c|c|c|c|c|}
\hline Bore & $\begin{array}{l}\text { Top } \\
(\mathrm{m})\end{array}$ & $\begin{array}{l}\text { Bottom } \\
\text { (m) }\end{array}$ & Simplified lithology & Driller's description \\
\hline Perc Est AFPL1 & 8.81 & 9.11 & $\begin{array}{l}\text { clay, sand and trace } \\
\text { gravel }\end{array}$ & $\begin{array}{l}\text { Silt and fine sand, occasional pebble, grayish orange } \\
\text { pink (5YR7/2), thin layers of mottled moderate yel- } \\
\text { lowish brown (10YR5/4) to light gray (N7) siltstone } \\
\text { (cemented). }\end{array}$ \\
\hline Perc Est AFPL2 & 0.00 & 0.24 & sand and clay & $\begin{array}{l}\text { Sand, fine, and silt, abundant organic matter and numerous } \\
\text { roots, loose, moist, dark yellowish brown }(10 \mathrm{YR} 4 / 2) \text {. }\end{array}$ \\
\hline Perc Est AFPL2 & 0.91 & 1.01 & sand and trace gravel & $\begin{array}{l}\text { Sand, coarse, and gravel, gravel as large as } 3 \mathrm{~cm} \text {, partly } \\
\text { cemented, no roots observed, grayish orange pink } \\
(5 \mathrm{YR} 7 / 2) \text {. Cored } 0.0-1.0 \text { meter, recovered } 1 \text { meter. } \\
\text { Encountered cemented interval at } 1 \text { meter. }\end{array}$ \\
\hline Perc Est AFPL2 & 1.01 & 1.13 & sand and gravel & $\begin{array}{l}\text { Drilled without core through a 7-cm layer of cemented } \\
\text { materials. }\end{array}$ \\
\hline Perc Est AFPL2 & 1.37 & 1.52 & sand and trace gravel & $\begin{array}{l}\text { Sand, coarse, and gravel, no roots observed, moist, moder- } \\
\text { ate brown }(5 \mathrm{YR} 4 / 4) \text {. }\end{array}$ \\
\hline Perc Est AFPL2 & 1.52 & 1.98 & sand and trace gravel & $\begin{array}{l}\text { Sand, coarse, and gravel, gravel as large as } 5 \mathrm{~cm} \text {, no } \\
\text { roots observed, moist, vertical wispy veins of a white } \\
\text { mineral, moderate yellowish brown (5YR7/2). Cored } \\
1.98-2.59 \mathrm{~m} \text {, recovered } 56 \mathrm{~cm} \text {. }\end{array}$ \\
\hline Perc Est AFPL2 & 1.98 & 2.07 & sand, clay and gravel & $\begin{array}{l}\text { Sand and gravel, some silt, cemented, moist, grayish } \\
\text { orange pink }(5 \mathrm{YR} 7 / 2) \text {. }\end{array}$ \\
\hline Perc Est AFPL2 & 2.07 & 2.23 & sand and trace gravel & $\begin{array}{l}\text { Sand, coarse, and gravel, little cementation, loose, pale yel- } \\
\text { lowish brown (10YR6/2). }\end{array}$ \\
\hline
\end{tabular}


Appendix 1. Compilation of borehole and aquifer data.-Continued

[cm, centimeter; m, meter; in, inch; ft, feet; \%, percent; ppm, parts per million; $\approx$, approximately equal to; $>$, greater than]

\begin{tabular}{|c|c|c|c|c|}
\hline Bore & $\begin{array}{l}\text { Top } \\
\text { (m) }\end{array}$ & $\begin{array}{c}\text { Bottom } \\
(\mathrm{m})\end{array}$ & Simplified lithology & Driller's description \\
\hline Perc Est AFPL2 & 2.23 & 2.53 & sand and trace gravel & $\begin{array}{l}\text { Sand, coarse, and gravel, gravel as large as } 6 \mathrm{~cm} \text {, numerous } \\
\text { black pebbles and coarse sand, little cementation, loose, } \\
\text { some roots present, pale yellowish brown }(10 \mathrm{YR} 6 / 2) \text {. }\end{array}$ \\
\hline Perc Est AFPL2 & 2.59 & 2.83 & sand and trace gravel & $\begin{array}{l}\text { Sand, coarse, and gravel, gravel as large as } 5 \mathrm{~cm} \text {, mostly } \\
\text { volcanic, white mineral nodules within sand and gravel, } \\
\text { whitish coating on larger stones. Cored } 2.59-2.83 \mathrm{~m} \text {, re- } \\
\text { covered } 24 \mathrm{~cm} \text {. Stopped coring because gravel too large. }\end{array}$ \\
\hline Perc Est AFPL2 & 2.83 & 3.72 & sand and gravel & Drilled to get past large gravel and cobbles. \\
\hline Perc Est AFPL2 & 4.11 & 4.57 & sand and clay & $\begin{array}{l}\text { Sand, medium well sorted, moist, moderate brown } \\
\text { (5YR4/4). Sand grades first to fine sand then to silty fine } \\
\text { sand with depth. Cored } 4.11-4.94 \mathrm{~m} \text {, recovered } 83 \mathrm{~cm} \text {. }\end{array}$ \\
\hline Perc Est AFPL2 & 4.57 & 4.94 & sand and clay & $\begin{array}{l}\text { Sand, fine and silt, well sorted, moderate yellowish brown } \\
\text { (5YR5/4). Several vertical veins of a white mineral } \\
\text { extend through interval. }\end{array}$ \\
\hline Perc Est AFPL2 & 6.55 & 6.71 & sand and clay & $\begin{array}{l}\text { Sand, fine and silt, minor whitish mineral, little cementa- } \\
\text { tion, moist, moderate yellowish brown }(10 \mathrm{YR} 5 / 4) \text {. } \\
\text { Cored } 6.55-7.16 \mathrm{~m} \text {, recovered } 61 \mathrm{~cm} \text {. }\end{array}$ \\
\hline Perc Est AFPL2 & 6.71 & 6.86 & $\begin{array}{l}\text { sand, clay and trace } \\
\text { gravel }\end{array}$ & Sand, medium and gravel, moist. \\
\hline Perc Est AFPL2 & 6.86 & 7.16 & sand and trace gravel & $\begin{array}{l}\text { Sand, fine, moderate yellowish brown }(10 \mathrm{YR} 5 / 4) \text {. Grades } \\
\text { to coarse sand and gravel at } 7.16 \mathrm{~m} \text {, no observed mineral } \\
\text { veins or nodules, moist. }\end{array}$ \\
\hline
\end{tabular}


Appendix 1. Compilation of borehole and aquifer data.-Continued

[cm, centimeter; $\mathrm{m}$, meter; in, inch; ft, feet; \%, percent; ppm, parts per million; $\approx$, approximately equal to; >, greater than]

\begin{tabular}{|c|c|c|c|c|}
\hline Bore & $\begin{array}{l}\text { Top } \\
(\mathrm{m})\end{array}$ & $\begin{array}{l}\text { Bottom } \\
\text { (m) }\end{array}$ & Simplified lithology & Driller's description \\
\hline Perc Est AFPL2 & 7.16 & 7.32 & sand and trace gravel & $\begin{array}{l}\text { Sand, coarse and fine gravel. Cored 7.16-7.99 m, } \\
\text { recovered } 82 \mathrm{~cm} .\end{array}$ \\
\hline Perc Est AFPL2 & 7.32 & 7.99 & $\begin{array}{l}\text { sand, clay and trace } \\
\text { gravel }\end{array}$ & $\begin{array}{l}\text { Sand, fine, and silt, occasional gravel as large as } 2 \mathrm{~cm} \text {, } \\
\text { moist, moderate yellowish brown }(10 \mathrm{YR} 5 / 4) \text {. A cylindri- } \\
\text { cal vein of a white mineral (calcite?) measured }<1 \mathrm{~cm} \text { in } \\
\text { diameter and was more than } 3 \mathrm{~cm} \text { long (old root trace?). }\end{array}$ \\
\hline Perc Est AFPL2 & 7.99 & 8.23 & $\begin{array}{l}\text { sand, clay and trace } \\
\text { gravel }\end{array}$ & $\begin{array}{l}\text { Sand, fine, and silt, occasional gravel as large as } 1 \mathrm{~cm} \text {, } \\
\text { loose, some white mineral veins, moist, moderate yel- } \\
\text { lowish brown (10YR5/4). Cored } 7.99-8.69 \mathrm{~m} \text {, recovered } \\
70 \mathrm{~cm} \text {. }\end{array}$ \\
\hline Perc Est AFPL2 & 8.38 & 8.69 & $\begin{array}{l}\text { sand, clay and trace } \\
\text { gravel }\end{array}$ & $\begin{array}{l}\text { Sand, fine, grading to sand and gravel, gravel as large } \\
\text { as } 1 \mathrm{~cm} \text {, loose, occasional white nodules in fine sand, } \\
\text { moist, moderate yellowish brown (10YR5/4). }\end{array}$ \\
\hline Perc Est AFPL2 & 8.69 & 8.72 & $\begin{array}{l}\text { sand, clay and trace } \\
\text { gravel }\end{array}$ & $\begin{array}{l}\text { Sand, fine, and silt, occasional pebble, white mineral } \\
\text { (calcite?) laced through core, moist, moderate yellowish } \\
\text { brown (10YR5/4). Cored 8.69-9.51 m, recovered } 79 \mathrm{~cm} \text {. }\end{array}$ \\
\hline Perc Est AFPL2 & 9.51 & 10.21 & $\begin{array}{l}\text { sand, clay and trace } \\
\text { gravel }\end{array}$ & $\begin{array}{l}\text { Sand, fine, and silt, occasional pebble, some minor yel- } \\
\text { low orange oxidation near top, numerous thin weakly } \\
\text { cemented layers, white mineral laced through core, mod- } \\
\text { erate yellowish brown (10YR5/4). Cored } 9.51-10.21 \mathrm{~m} \text {, } \\
\text { recovered } 70 \mathrm{~cm} \text {. }\end{array}$ \\
\hline Perc Est AFPL2 & 10.21 & 10.52 & sand & $\begin{array}{l}\text { Sand, fine, well sorted, no white minerals, moist, moder- } \\
\text { ate yellowish brown (10YR5/4). Cored 10.21-11.06 m, } \\
\text { recovered } 85 \mathrm{~cm} .\end{array}$ \\
\hline Perc Est AFPL2 & 10.52 & 10.82 & $\begin{array}{l}\text { sand, clay and trace } \\
\text { gravel }\end{array}$ & $\begin{array}{l}\text { Sand and gravel, some silt, gravel as large as } 1 \mathrm{~cm} \text {, moist, } \\
\text { occasional bleb of white mineral. }\end{array}$ \\
\hline Perc Est AFPL2 & 10.82 & 10.97 & $\begin{array}{l}\text { sand, clay and trace } \\
\text { gravel }\end{array}$ & $\begin{array}{l}\text { Sand, fine, and silt, occasional pebble, considerable calcite } \\
\text { (?) and thin lenses of cemented sandstone, moist, grayish } \\
\text { orange pink (5YR7/2). }\end{array}$ \\
\hline
\end{tabular}


Appendix 1. Compilation of borehole and aquifer data.-Continued

[cm, centimeter; m, meter; in, inch; ft, feet; \%, percent; ppm, parts per million; $\approx$, approximately equal to; $>$, greater than]

\begin{tabular}{|c|c|c|c|c|}
\hline Bore & $\begin{array}{l}\text { Top } \\
(\mathrm{m})\end{array}$ & $\begin{array}{l}\text { Bottom } \\
(\mathrm{m})\end{array}$ & Simplified lithology & Driller's description \\
\hline Perc Est AFPL2 & 10.97 & 11.06 & $\begin{array}{l}\text { sand, clay and trace } \\
\text { gravel }\end{array}$ & $\begin{array}{l}\text { Sand, fine, and silt, occasional pebble, minor white mineral } \\
\text { (calcite?), moist, moderate yellowish brown (10YR5/4). }\end{array}$ \\
\hline Perc Est AFPL2 & 11.06 & 11.73 & $\begin{array}{l}\text { sand, clay and trace } \\
\text { gravel }\end{array}$ & $\begin{array}{l}\text { Sand, fine, and silt, occasional gravel, damp, thin lay- } \\
\text { ers of cemented sandstone, moderate yellowish brown } \\
\text { (10YR5/4). Cored } 11.06-11.73 \mathrm{~m} \text {, recovered } 67 \mathrm{~cm} \text {. }\end{array}$ \\
\hline Perc Est AFPL2 & 11.73 & 11.86 & $\begin{array}{l}\text { sand, clay and trace } \\
\text { gravel }\end{array}$ & $\begin{array}{l}\text { Siltstone, occasional small pebble, highly cemented, occa- } \\
\text { sional veins of a whitish mineral, dry to damp, moderate } \\
\text { yellowish brown }(10 \mathrm{YR} 5 / 4) \text {. Cored } 11.73-12.65 \mathrm{~m} \text {, } \\
\text { recovered } 89 \mathrm{~cm} \text {. }\end{array}$ \\
\hline Perc Est AFPL2 & 12.34 & 12.62 & sand and clay & $\begin{array}{l}\text { Sand, fine, and silt, weakly cemented, numerous veins and } \\
\text { blebs of a whitish mineral, moist, moderate yellowish } \\
\text { brown (10YR5/4). }\end{array}$ \\
\hline Perc Est AFPL2 & 12.65 & 12.95 & $\begin{array}{l}\text { sand, clay and trace } \\
\text { gravel }\end{array}$ & $\begin{array}{l}\text { Sand, fine, and silt, occasional pebble and bleb of whitish } \\
\text { mineral, moist, moderate yellowish brown }(10 \mathrm{YR} 5 / 4) \text {. } \\
\text { At } 42.5 \text {, two thin layers of siltstone, cemented, oc- } \\
\text { casional pebble, very pale orange }(10 \mathrm{YR} 8 / 2) \text {. Cored } \\
12.65-13.26 \mathrm{~m} \text {, recovered } 61 \mathrm{~cm} \text {. }\end{array}$ \\
\hline Perc Est AFPL2 & 13.50 & 13.78 & nonwelded tuff & $\begin{array}{l}\text { Volcanic ash, very fine sand, well sorted and uniform, } \\
\text { loose, moist, very light gray (N8). Ash identified as } \\
\text { Lava Creek B with an age of } 0.64 \text { Ma (Andrei Sarna- } \\
\text { Wojcicki, U.S. Geological Survey, Menlo Park, written } \\
\text { commun., 2002). }\end{array}$ \\
\hline Perc Est AFPL2 & 13.78 & 14.02 & sand & $\begin{array}{l}\text { Sand, very fine, } 1 \mathrm{~cm} \text { thick layers of cemented sand, moist, } \\
\text { pale yellowish brown }(10 \mathrm{YR} 6 / 2) \text {. }\end{array}$ \\
\hline Perc Est AFPL2 & 14.02 & 14.14 & sand & $\begin{array}{l}\text { Sand, very fine, occasional bleb of whitish mineral, loose, } \\
\text { moist, pale yellowish brown (10YR6/2). }\end{array}$ \\
\hline Perc Est AFPL2 & 14.14 & 14.63 & sand & $\begin{array}{l}\text { Sand, fine, well sorted, occasional bleb of whitish mineral, } \\
\text { loose, moist, pale yellowish brown (10YR6/2). Cored } \\
14.14-14.81 \mathrm{~m} \text {, recovered } 67 \mathrm{~cm} \text {. }\end{array}$ \\
\hline
\end{tabular}


Appendix 1. Compilation of borehole and aquifer data.-Continued

[cm, centimeter; $\mathrm{m}$, meter; in, inch; ft, feet; \%, percent; ppm, parts per million; $\approx$, approximately equal to; >, greater than]

\begin{tabular}{ccccc}
\hline Bore & $\begin{array}{c}\text { Top } \\
(\mathbf{m})\end{array}$ & $\begin{array}{c}\text { Bottom } \\
(\mathbf{m})\end{array}$ & Simplified lithology & Driller's description \\
\hline Perc Est AFPL2 & 14.63 & 14.81 & sand & $\begin{array}{c}\text { Sand, fine, well sorted, occasional bleb of whitish min } \\
\text { loose, moist, very pale orange (10YR8/2). }\end{array}$ \\
Perc Est AFPL2 & 14.81 & 15.12 & sand and trace gravel & $\begin{array}{c}\text { Sand, fine, well sorted, occasional pebble, occasional } \\
\text { bleb of whitish mineral, loose, moist, very pale orange } \\
\text { (10YR8/2). Cored 14.81-15.73 m, recovered 92 cm. }\end{array}$ \\
Perc Est AFPL2 & & & & sand and trace gravel \\
& 15.12 & 15.42 & & $\begin{array}{c}\text { Sand, fine, well sorted, occasional pebble, occasional } \\
\text { cemented zone, moist, grayish yellow (5Y8/4) with } \\
\text { oxidized yellowish orange streaks. }\end{array}$
\end{tabular}

Perc Est AFPL2

15.42

15.73

sand and trace gravel

Perc Est AFPL2

15.73

15.94

sand, clay and trace gravel

Perc Est AFPL2

Perk Est. ARAS1

0.00

0.76

sand and trace gravel

Perk Est. ARAS1

Perk Est. ARAS1

Perk Est. ARAS1

Perk Est. ARAS1

3.51

4.11

5.09

5.09

5.64

Perk Est. ARAS1

Perk Est. ARAS1
4.11

sand, clay and gravel

sand, clay and gravel

sand, clay and gravel

1.98 sand, clay and gravel

2.59 sand, clay and gravel

sand, clay and gravel

Sand and gravel, some silt, moderately sorted, wet. Perched water. Cored 2.59-3.51 m, recovered $92 \mathrm{~cm}$.

Sand and gravel, some silt, moderately sorted, moist. Cored $3.51-4.11 \mathrm{~m}$, recovered $60 \mathrm{~cm}$.

Sand and gravel, some silt, moderately sorted, moist. Cored 4.11-5.09 m, recovered $98 \mathrm{~cm}$.

Sand and gravel, some silt, moderately sorted, moist. Cored 5.09-5.64 m, recovered $55 \mathrm{~cm}$.

Sand and gravel, some silt, moderately sorted, moist. Cored 5.64-6.55 m, recovered $76 \mathrm{~cm}$. 
Appendix 1. Compilation of borehole and aquifer data.-Continued

[cm, centimeter; $\mathrm{m}$, meter; in, inch; ft, feet; \%, percent; ppm, parts per million; $\approx$, approximately equal to; >, greater than]

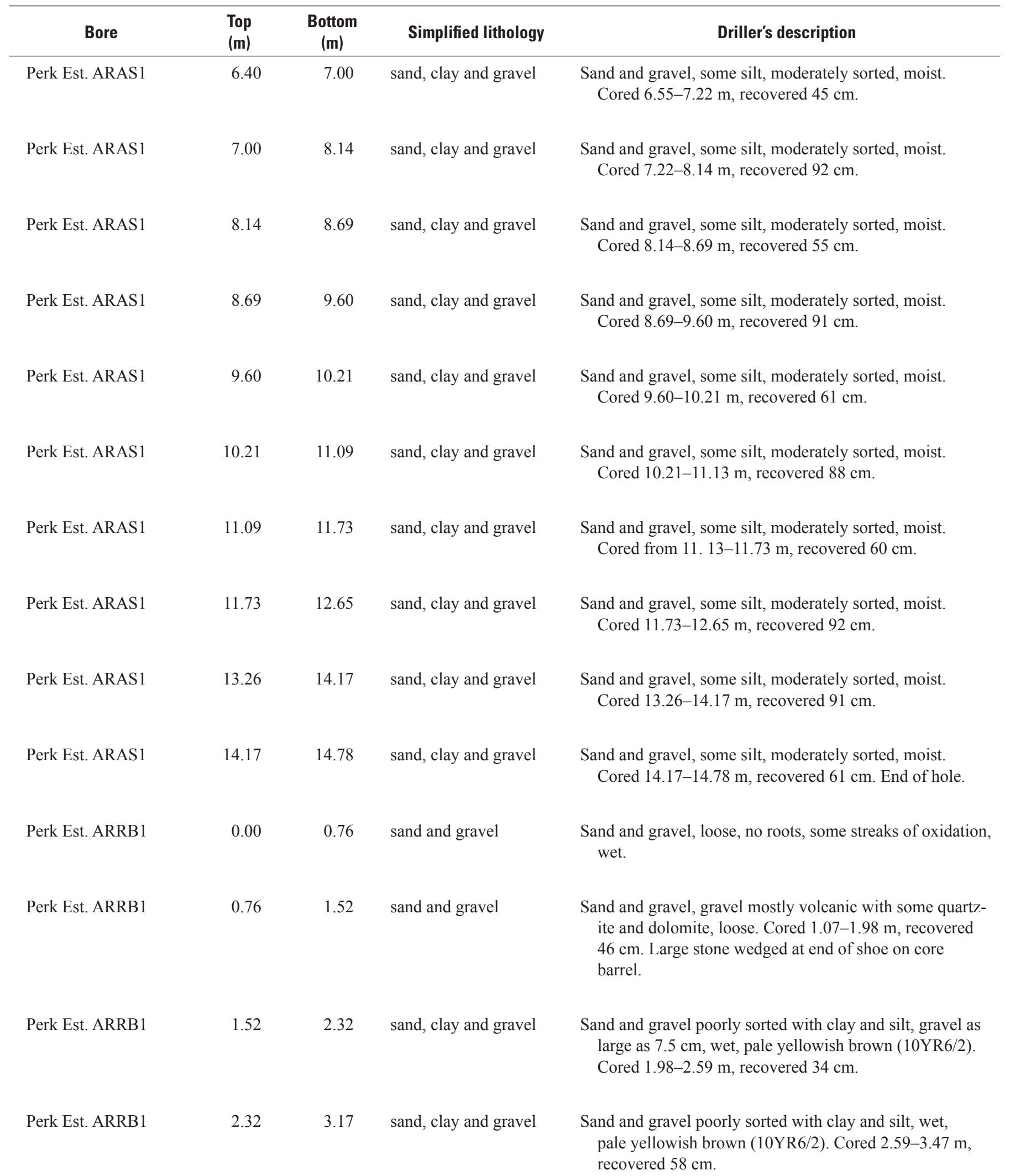


Appendix 1. Compilation of borehole and aquifer data.-Continued

[cm, centimeter; $\mathrm{m}$, meter; in, inch; ft, feet; \%, percent; ppm, parts per million; $\approx$, approximately equal to; >, greater than]

\begin{tabular}{|c|c|c|c|c|}
\hline Bore & $\begin{array}{l}\text { Top } \\
\text { (m) }\end{array}$ & $\begin{array}{c}\text { Bottom } \\
\text { (m) }\end{array}$ & Simplified lithology & Driller's description \\
\hline Perk Est. ARRB1 & 3.17 & 4.11 & sand, clay and gravel & $\begin{array}{l}\text { Sand and gravel poorly sorted with clay and silt, gravel } \\
>5 \mathrm{~cm} \text {, wet, pale yellowish brown }(10 \mathrm{YR} 6 / 2) \text {. Cored } \\
3.47-4.11 \mathrm{~m} \text {, recovered } 64 \mathrm{~cm} \text {. }\end{array}$ \\
\hline Perk Est. ARRB1 & 4.11 & 4.89 & sand, clay and gravel & $\begin{array}{l}\text { Sand and gravel poorly sorted with clay and silt, gravel } \\
>7.5 \mathrm{~cm} \text {, compact yet not cemented, moist, multicolored. } \\
\text { In middle of core (at about } 4.57 \mathrm{~m} \text { ), a large quartzite } \\
\text { stone, same size as the } 7.5 \mathrm{~cm} \text { diameter core barrel } \\
\text { except the edges had been rounded to fit tightly in barrel. } \\
467 \text { Cored } 4.11-5.03 \mathrm{~m} \text {, recovered } 76 \mathrm{~cm} \text {. }\end{array}$ \\
\hline
\end{tabular}

Perk Est. ARRB1

4.89

5.61 sand, clay and gravel

Perk Est. ARRB1

Perk Est. ARRB1

Perk Est. ARRB1

Perk Est. ARRB1

Perk Est. ARRB1

8.69

9.60

sand, clay and gravel

Perk Est. ARRB1

9.60

10.21

sand, clay and gravel

Perk Est. ARRB1

10.21

10.91
Sand and gravel poorly sorted with clay and silt, gravel highly weathered, moist, multicolored. Cored $5.03-5.61 \mathrm{~m}$, recovered $58 \mathrm{~cm}$.

Sand and gravel poorly sorted with clay and silt, compact yet not cemented, gravel highly weathered, moist, light brown $(5$ YR5/6). Stopped coring because shoe grinding on large stone. Bottom of shoe had a $3-\mathrm{cm}$ thick piece of freshly broken basalt. Cored 5.61-6.40 m, recovered $79 \mathrm{~cm}$.

Sand and gravel poorly sorted with silt and minor clay, gravel moderately weathered, moist, light brown (5YR5/6). Matching piece of freshly broken basalt at $6.40 \mathrm{~m}$. Cored 6.40-7.16 m, recovered $73 \mathrm{~cm}$.

Sand and gravel poorly sorted with silt and minor clay, gravel moderately weathered, moist but drier and warmer than above, light brown (5YR5/6). Cored 7.16-8.08 $\mathrm{m}$, recovered $92 \mathrm{~cm}$.

Sand and gravel poorly sorted with clay and silt, damp and warm, light brown (5YR5/6). Cored 8.08-8.69 m, recovered $61 \mathrm{~cm}$.

Sand and gravel poorly sorted with clay and silt, damp and warm, light brown (5YR5/6). Cored 8.69-9.60 m, recovered $0.91 \mathrm{~cm}$.

Sand and gravel poorly sorted with clay and silt, wetter than above, light brown (5YR5/6). Cored 9.60-10.21 m, recovered $61 \mathrm{~cm}$.

Sand and gravel poorly sorted with clay and silt, gravel moderately weathered, moist, light brown (5YR5/6). Cored 10.21-10.91 m, recovered $70 \mathrm{~cm}$. Stopped on a boulder-could not continue coring. Drilled through boulder with inner bit. 
Appendix 1. Compilation of borehole and aquifer data.-Continued

[cm, centimeter; $\mathrm{m}$, meter; in, inch; $\mathrm{ft}$, feet; \%, percent; ppm, parts per million; $\approx$, approximately equal to; >, greater than]

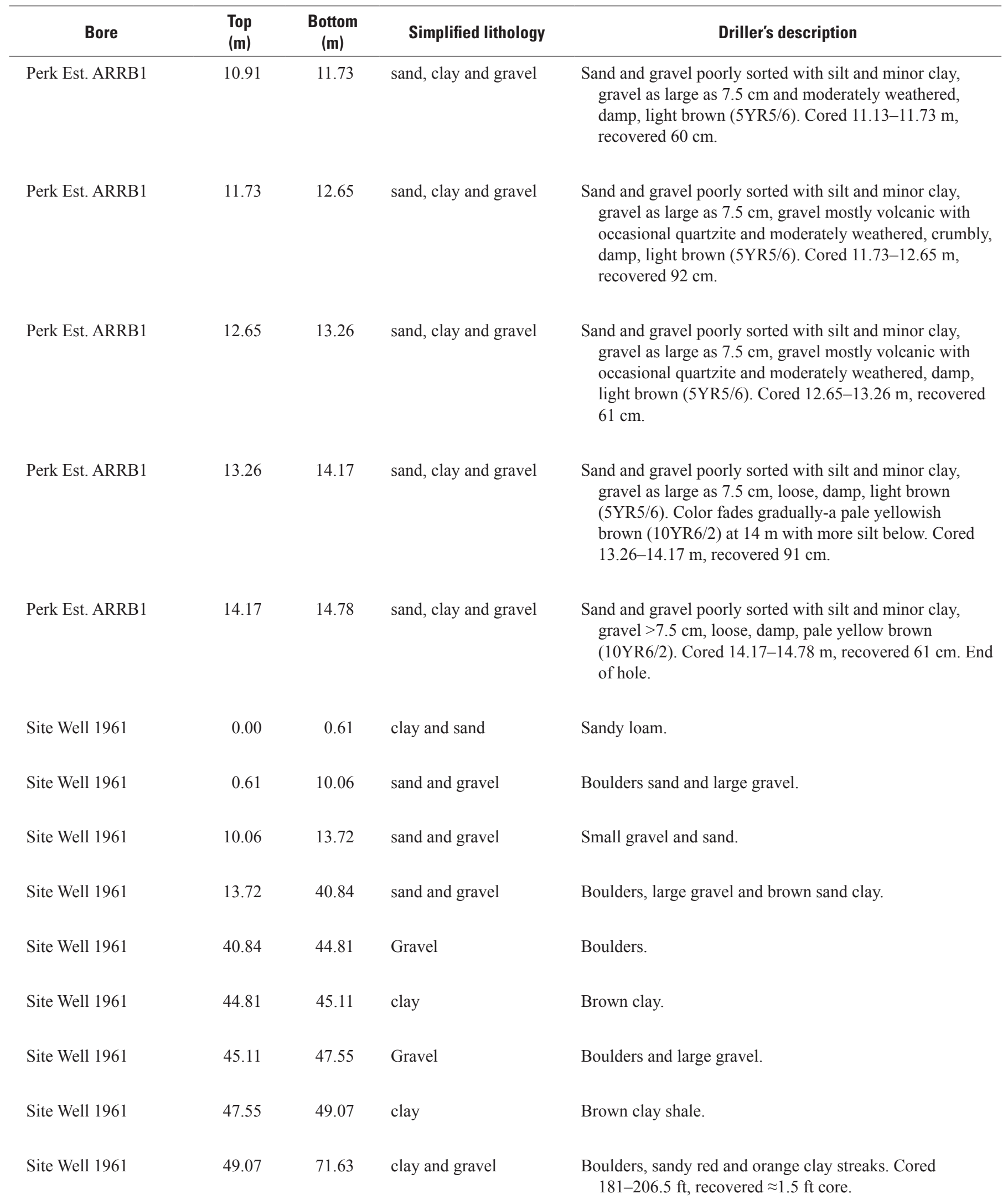


Appendix 1. Compilation of borehole and aquifer data.-Continued

[cm, centimeter; $\mathrm{m}$, meter; in, inch; ft, feet; \%, percent; ppm, parts per million; $\approx$, approximately equal to; >, greater than]

\begin{tabular}{|c|c|c|c|c|}
\hline Bore & $\begin{array}{l}\text { Top } \\
\text { (m) }\end{array}$ & $\begin{array}{c}\text { Bottom } \\
\text { (m) }\end{array}$ & Simplified lithology & Driller's description \\
\hline Site Well 1961 & 71.63 & 80.77 & Gravel & Boulders and large gravel. \\
\hline Site Well 1961 & 80.77 & 92.05 & clay & Brown clay. Cored 275-280 ft recovered $5 \mathrm{ft}$ core. \\
\hline Site Well 1961 & 93.88 & 98.15 & clay & Brown bentonitic clay. \\
\hline Site Well 1961 & 98.15 & 107.90 & clay & Multicolored boulders with yellow clay. \\
\hline Site Well 1961 & 115.21 & 117.04 & clay & Greenish brown clay. \\
\hline Site Well 1961 & 117.04 & 123.75 & clay and gravel & White bentonitic clay and boulders. \\
\hline Site Well 1961 & 123.75 & 129.54 & clay & Brown clay. \\
\hline Site Well 1961 & 129.54 & 132.89 & clay and gravel & Quartzite. \\
\hline Site Well 1961 & 143.87 & 148.74 & Gravel & Boulders, large and small water gravel. \\
\hline Site Well 1961 & 148.74 & 161.24 & clay and gravel & Reddish brown clay, shale and boulders. \\
\hline Site Well 1961 & 161.24 & 163.98 & clay & Brown bentonitic clay. \\
\hline Site Well 1961 & 163.98 & 168.55 & Gravel & Boulders. \\
\hline Site Well 1961 & 168.55 & 170.99 & Gravel & Small water gravel. \\
\hline Site Well 1961 & 170.99 & 172.52 & clay and gravel & Small gravel and streaks of yellow clay. \\
\hline Site Well 1961 & 172.52 & 175.26 & sand & Hard compacted sand. \\
\hline
\end{tabular}


Appendix 1. Compilation of borehole and aquifer data.-Continued

[cm, centimeter; $\mathrm{m}$, meter; in, inch; $\mathrm{ft}$, feet; \%, percent; ppm, parts per million; $\approx$, approximately equal to; >, greater than]

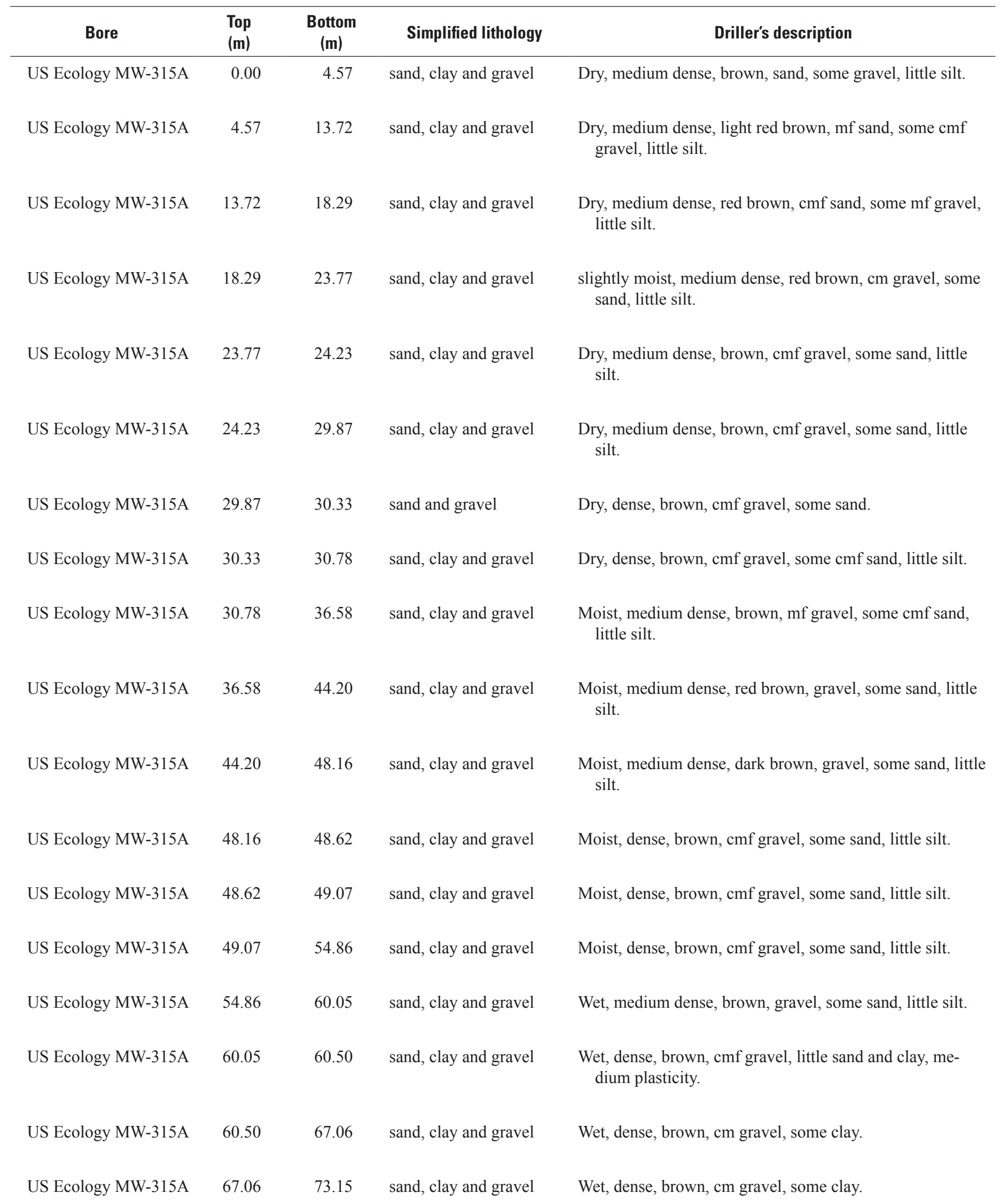


Appendix 1. Compilation of borehole and aquifer data.-Continued

[cm, centimeter; $\mathrm{m}$, meter; in, inch; ft, feet; \%, percent; ppm, parts per million; $\approx$, approximately equal to; >, greater than]

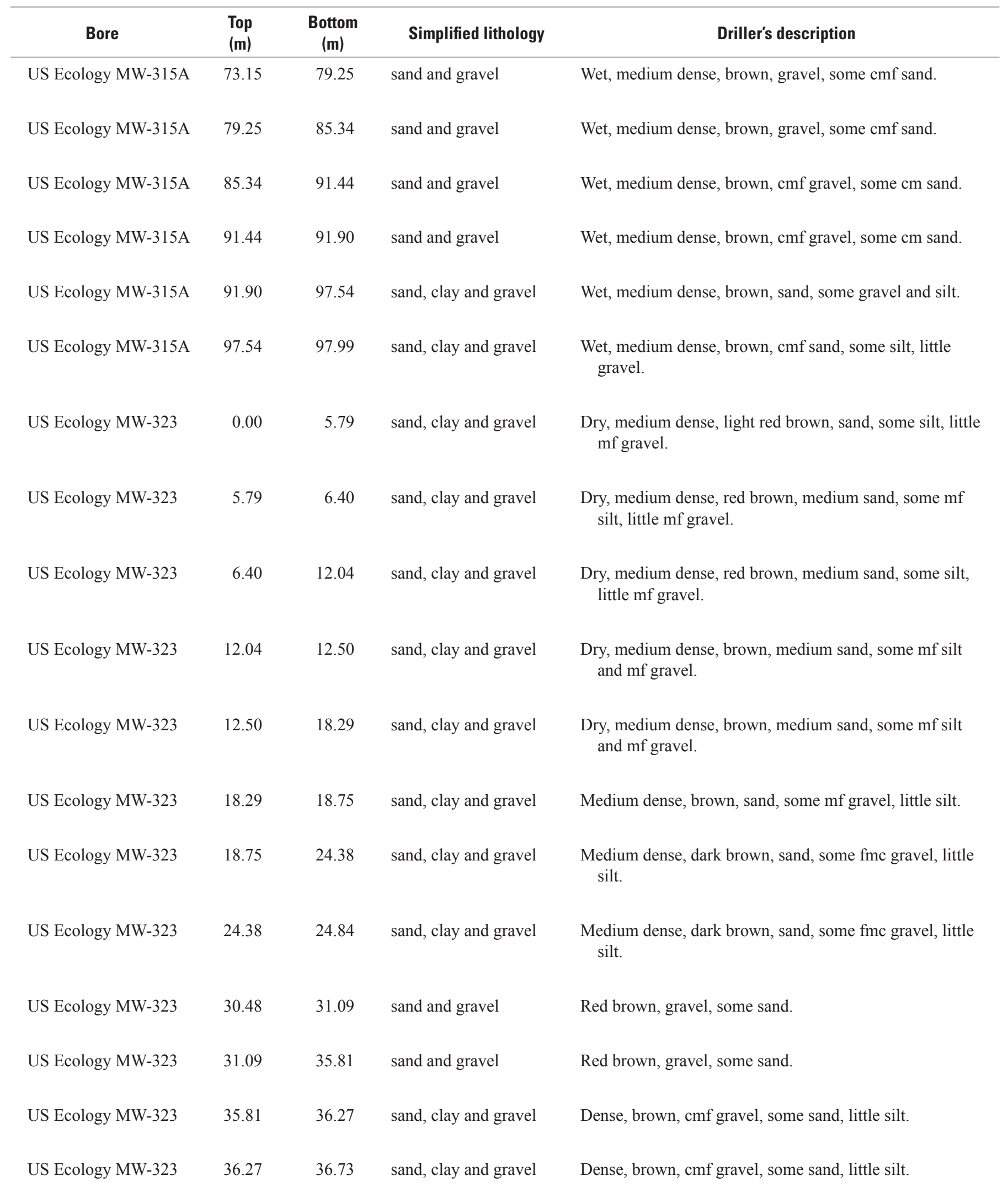


Appendix 1. Compilation of borehole and aquifer data.-Continued

[cm, centimeter; $\mathrm{m}$, meter; in, inch; $\mathrm{ft}$, feet; \%, percent; ppm, parts per million; $\approx$, approximately equal to; >, greater than]

\begin{tabular}{|c|c|c|c|c|}
\hline Bore & $\begin{array}{l}\text { Top } \\
(\mathrm{m})\end{array}$ & $\begin{array}{l}\text { Bottom } \\
(\mathrm{m})\end{array}$ & Simplified lithology & Driller's description \\
\hline US Ecology MW-323 & 36.73 & 42.21 & sand and gravel & Moist, medium dense, brown, sand, some mf gravel. \\
\hline US Ecology MW-323 & 42.21 & 42.67 & sand, clay and gravel & $\begin{array}{l}\text { Wet, medium dense, brown, cmf gravel, some sand, little } \\
\text { silt. }\end{array}$ \\
\hline US Ecology MW-323 & 48.16 & 48.62 & sand and gravel & Medium dense, red brown, cmf gravel, some sand. \\
\hline US Ecology MW-323 & 54.86 & 55.32 & sand and gravel & Wet, medium dense, brown, cm gravel, some coarse sand. \\
\hline US Ecology MW-323 & 55.32 & 59.44 & sand, clay and gravel & $\begin{array}{l}\text { Wet, medium dense, brown, cm gravel, some sand, little } \\
\text { clay. }\end{array}$ \\
\hline US Ecology MW-323 & 59.44 & 59.89 & sand, clay and gravel & $\begin{array}{l}\text { Wet, medium dense, brown, gravel, some sand, little silt } \\
\text { and clay. }\end{array}$ \\
\hline US Ecology MW-323 & 67.06 & 72.54 & sand, clay and gravel & Wet, brown, cmf sand, some medium gravel and silt. \\
\hline US Ecology MW-323 & 72.54 & 73.00 & sand, clay and gravel & $\begin{array}{l}\text { Wet, medium dense, brown, cmf sand, some medium } \\
\text { gravel and silt. }\end{array}$ \\
\hline US Ecology MW-323 & 73.00 & 78.79 & sand, clay and gravel & $\begin{array}{l}\text { Wet, medium dense, brown, cmf sand, some medium } \\
\text { gravel and silt. }\end{array}$ \\
\hline US Ecology MW-323 & 78.79 & 79.25 & sand, clay and gravel & $\begin{array}{l}\text { Wet, medium dense, brown, cmf gravel, some } \mathrm{cmf} \text { sand, } \\
\text { little silt. }\end{array}$ \\
\hline US Ecology MW-323 & 79.25 & 79.71 & sand, clay and gravel & $\begin{array}{l}\text { Wet, medium dense, brown, cmf gravel, some } \mathrm{cmf} \text { sand, } \\
\text { little silt. }\end{array}$ \\
\hline US Ecology MW-323 & 79.71 & 80.16 & sand, clay and gravel & $\begin{array}{l}\text { Wet, medium dense, brown, cmf gravel, some cmf sand, } \\
\text { little silt. }\end{array}$ \\
\hline
\end{tabular}


Appendix 1. Compilation of borehole and aquifer data.-Continued

[cm, centimeter; $\mathrm{m}$, meter; in, inch; ft, feet; \%, percent; ppm, parts per million; $\approx$, approximately equal to; >, greater than]

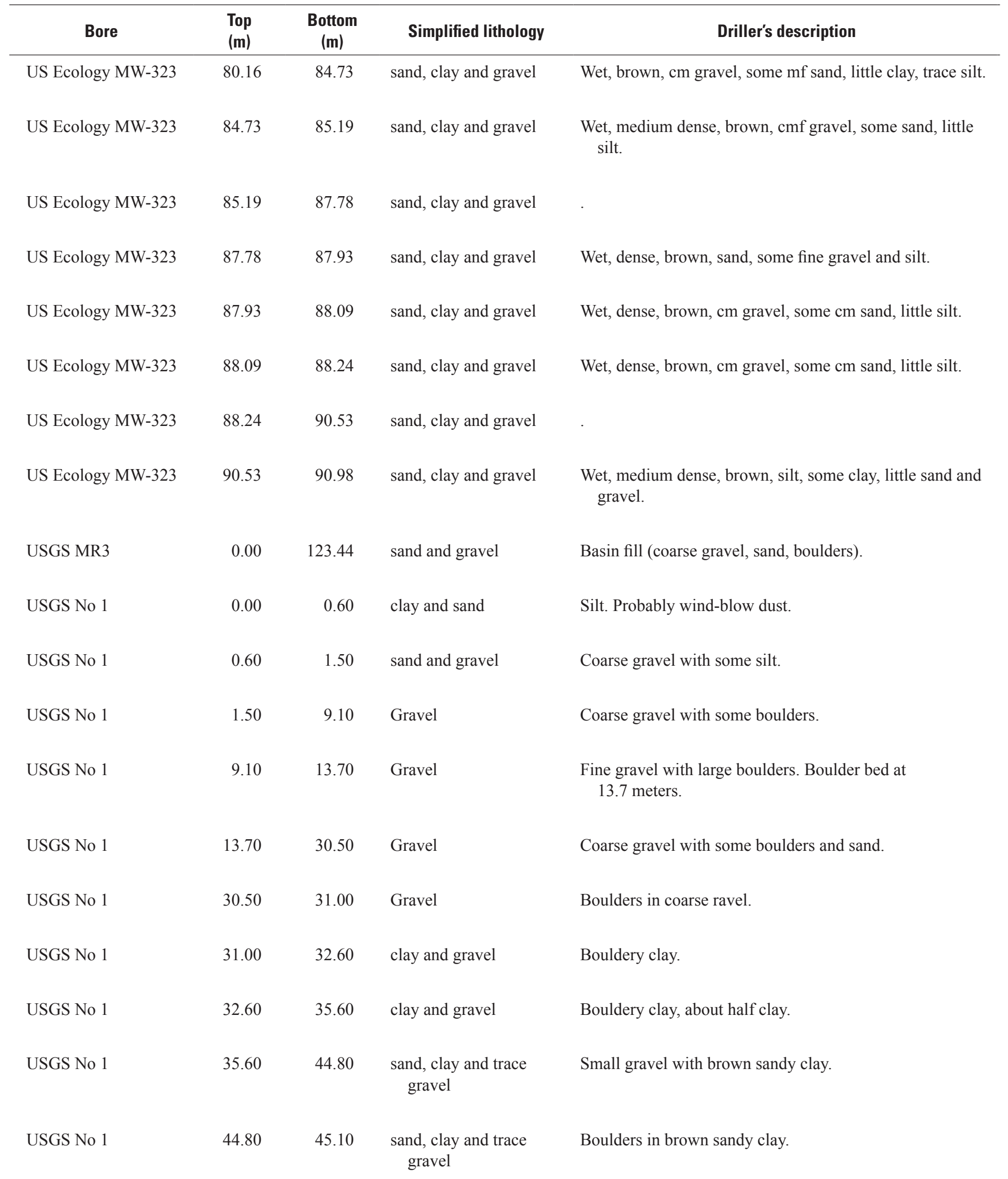


Appendix 1. Compilation of borehole and aquifer data.-Continued

[cm, centimeter; $\mathrm{m}$, meter; in, inch; $\mathrm{ft}$, feet; \%, percent; ppm, parts per million; $\approx$, approximately equal to; >, greater than]

\begin{tabular}{|c|c|c|c|c|}
\hline Bore & $\begin{array}{l}\text { Top } \\
(\mathrm{m})\end{array}$ & $\begin{array}{l}\text { Bottom } \\
(\mathrm{m})\end{array}$ & Simplified lithology & Driller's description \\
\hline USGS No 1 & 45.10 & 47.80 & $\begin{array}{l}\text { sand, clay and trace } \\
\text { gravel }\end{array}$ & Boulders with some clay. \\
\hline USGS No 1 & 47.80 & 49.00 & clay and gravel & Boulders and gravel in orange clay. \\
\hline USGS No 1 & 52.10 & 55.10 & clay & Reddish-orange clay. \\
\hline USGS No 1 & 55.10 & 60.60 & clay & Cored in bentonitic red and orange clay. No core recovery. \\
\hline USGS No 1 & 61.50 & 62.80 & clay & $\begin{array}{l}\text { Cored. No core recovered. Considerable brown clay from } \\
\text { bit. }\end{array}$ \\
\hline USGS No 1 & 62.80 & 71.60 & clay, sand and gravel & $\begin{array}{l}\text { Clayey gravel with boulders, brown clay, and small gravel } \\
\text { at } 71.6 \text { meters. }\end{array}$ \\
\hline USGS No 1 & 71.60 & 78.60 & sand, clay and gravel & Fine clayey gravel. Pinkish clay. \\
\hline USGS No 1 & 78.60 & 80.80 & Gravel & Gravel and boulders with but little clay. \\
\hline USGS No 1 & 92.00 & 93.90 & clay & $\begin{array}{l}\text { White and brown bentonitic clay with layers of bright- } \\
\text { yellow clay. }\end{array}$ \\
\hline USGS No 1 & 93.90 & 98.50 & clay and gravel & $\begin{array}{l}\text { Brown swelling clay with some gravel. Mostly clay } \\
\quad 80.8-98.1 \mathrm{~m} .\end{array}$ \\
\hline USGS No 1 & 98.50 & 98.80 & clay, sand and gravel & Boulders in brown sandy clay. \\
\hline USGS No 1 & 98.80 & 99.40 & clay & yellow clay. \\
\hline USGS No 1 & 99.40 & 103.60 & Gravel & Boulders but with little clay. Possible water zone. \\
\hline USGS No 1 & 103.60 & 106.40 & clay and limestone & $\begin{array}{l}\text { White to brown clay. White argillaceous carbonate rock } \\
\text { altered to clay. }\end{array}$ \\
\hline
\end{tabular}


Appendix 1. Compilation of borehole and aquifer data.-Continued

[cm, centimeter; $\mathrm{m}$, meter; in, inch; ft, feet; \%, percent; ppm, parts per million; $\approx$, approximately equal to; $>$, greater than]

\begin{tabular}{|c|c|c|c|c|}
\hline Bore & $\begin{array}{l}\text { Top } \\
(\mathrm{m})\end{array}$ & $\begin{array}{l}\text { Bottom } \\
(\mathrm{m})\end{array}$ & Simplified lithology & Driller's description \\
\hline USGS No 1 & 106.40 & 108.50 & limestone & $\begin{array}{l}\text { White carbonate rock. Largely altered to clay } \\
108.2-108.5 \mathrm{~m} \text {. }\end{array}$ \\
\hline USGS No 1 & 108.50 & 112.10 & clay and gravel & Bouldery brown clay. \\
\hline USGS No 1 & 112.80 & 117.00 & clay, sand and gravel & Dark volcanic boulders with brown bentonitic sandy-clay. \\
\hline USGS No 1 & 117.00 & 123.70 & clay and limestone & White carbonate rock somewhat altered to clay. \\
\hline USGS No 1 & 129.50 & 132.60 & clay and limestone & White carbonate rock and white clay. \\
\hline USGS No 1 & 132.60 & 135.60 & clay and gravel & Boulders in red clay. \\
\hline USGS No 1 & 135.60 & 142.30 & Gravel & Hard boulders with gravel in dark-red clay. Volcanic rocks. \\
\hline USGS No 1 & 142.30 & 144.50 & clay and gravel & Boulders and clay. Red clay at 143.9 meters. \\
\hline USGS No 1 & 144.50 & 148.70 & clay and gravel & $\begin{array}{l}\text { A variety of boulders with but little clay. A possible source } \\
\text { of water. }\end{array}$ \\
\hline USGS No 1 & 161.20 & 166.10 & clay and gravel & Boulders in pink and light-brown clay. Some silicic rock. \\
\hline USGS No 1 & 166.10 & 168.50 & clay and gravel & Boulders in clay. Some rounded gravel. \\
\hline USGS No 1 & 168.50 & 172.80 & clay and gravel & $\begin{array}{l}\text { Boulders in brown clay. Yellow clay and small gravel at } \\
171.0 \text { meters. }\end{array}$ \\
\hline USGS No 1 & 172.80 & 175.00 & dolomite/limestone & $\begin{array}{l}\text { Light gray metamorphic rocks. Large boulders or possibly } \\
\text { basement rock. }\end{array}$ \\
\hline USGS UZB-1 & 2.29 & 2.90 & sand, clay and gravel & $\begin{array}{l}\text { Cored, mixture of gravel and sand with some clay reddish } \\
\text { brown. }\end{array}$ \\
\hline USGS UZB-1 & 5.33 & 5.94 & sand, clay and gravel & $\begin{array}{l}\text { Cored, mixture of gravel and sand with some clay reddish } \\
\text { brown. }\end{array}$ \\
\hline
\end{tabular}


Appendix 1. Compilation of borehole and aquifer data.-Continued

[cm, centimeter; $\mathrm{m}$, meter; in, inch; ft, feet; \%, percent; ppm, parts per million; $\approx$, approximately equal to; >, greater than]

\begin{tabular}{|c|c|c|c|c|}
\hline Bore & $\begin{array}{l}\text { Top } \\
\text { (m) }\end{array}$ & $\begin{array}{l}\text { Bottom } \\
\text { (m) }\end{array}$ & Simplified lithology & Driller's description \\
\hline USGS UZB-1 & 8.63 & 9.24 & sand, clay and gravel & $\begin{array}{l}\text { Cored, mixture of gravel and sand with some clay reddish } \\
\text { brown. }\end{array}$ \\
\hline USGS UZB-1 & 11.40 & 12.01 & sand, clay and gravel & $\begin{array}{l}\text { Cored, mixture of gravel and sand with some clay reddish } \\
\text { brown. }\end{array}$ \\
\hline USGS UZB-1 & 14.72 & 15.33 & sand, clay and gravel & $\begin{array}{l}\text { Cored, mixture of gravel and sand with some clay reddish } \\
\text { brown. }\end{array}$ \\
\hline USGS UZB-1 & 17.53 & 18.14 & sand, clay and gravel & $\begin{array}{l}\text { Cored, mixture of gravel and sand with some clay reddish } \\
\text { brown. }\end{array}$ \\
\hline USGS UZB-1 & 21.34 & 24.38 & sand, clay and gravel & $\begin{array}{l}\text { No core below } 70 \mathrm{ft} \text { sand silt and gravel angular chips from } \\
\text { drill cuttings. }\end{array}$ \\
\hline USGS UZB-1 & 24.38 & 48.25 & sand and gravel & $\begin{array}{l}\text { Sand and gravel, few fines, higher moisture content than } \\
\text { above } 80 \mathrm{ft} \text {. }\end{array}$ \\
\hline USGS UZB-2 & 0.00 & 0.30 & $\begin{array}{l}\text { sand, clay and trace } \\
\text { gravel }\end{array}$ & Gravelly silts. \\
\hline USGS UZB-2 & 7.62 & 9.14 & sand and clay & Silty sand. \\
\hline USGS UZB-2 & 9.14 & 10.67 & sand and gravel & Sandy gravel. \\
\hline USGS UZB-2 & 10.67 & 11.28 & sand and trace gravel & Gravelly sand. \\
\hline USGS UZB-2 & 11.28 & 11.58 & Gravel & Gravel. \\
\hline USGS UZB-2 & 11.89 & 12.50 & sand and gravel & Sand gravel. \\
\hline USGS UZB-2 & 12.50 & 15.24 & sand, clay and gravel & Silty gravel. \\
\hline USGS UZB-2 & 15.24 & 16.76 & clay, sand and gravel & Sandy silty gravel. \\
\hline
\end{tabular}


Appendix 1. Compilation of borehole and aquifer data.-Continued

[cm, centimeter; $\mathrm{m}$, meter; in, inch; ft, feet; \%, percent; ppm, parts per million; $\approx$, approximately equal to; >, greater than]

\begin{tabular}{|c|c|c|c|c|}
\hline Bore & $\begin{array}{l}\text { Top } \\
\text { (m) }\end{array}$ & $\begin{array}{c}\text { Bottom } \\
\text { (m) }\end{array}$ & Simplified lithology & Driller's description \\
\hline USGS UZB-2 & 16.76 & 18.90 & sand and trace gravel & Gravelly sand. \\
\hline USGS UZB-2 & 18.90 & 19.81 & sand and gravel & Sandy gravel. \\
\hline USGS UZB-2 & 19.81 & 21.34 & Gravel & Gravel. \\
\hline USGS UZB-2 & 21.34 & 21.95 & sand and gravel & Sandy gravel. \\
\hline USGS UZB-2 & 21.95 & 22.56 & sand, clay and gravel & Silty gravel. \\
\hline USGS UZB-2 & 22.56 & 23.47 & Gravel & Gravel. \\
\hline USGS UZB-2 & 23.47 & 24.38 & clay, sand and gravel & Sandy silty gravel. \\
\hline USGS UZB-2 & 24.38 & 24.99 & sand and gravel & Sandy gravel. \\
\hline USGS UZB-2 & 24.99 & 25.91 & Gravel & Gravel. \\
\hline USGS UZB-2 & 25.91 & 26.21 & sand, clay and gravel & Silty gravel. \\
\hline USGS UZB-2 & 26.21 & 26.82 & sand, clay and gravel & Silty sandy gravel. \\
\hline USGS UZB-2 & 26.82 & 28.35 & sand, clay and gravel & Silty gravel. \\
\hline USGS UZB-2 & 28.35 & 29.26 & sand, clay and gravel & Silty sandy gravel. \\
\hline USGS UZB-2 & 29.26 & 30.48 & sand and gravel & Sandy gravel. \\
\hline USGS UZB-2 & 30.48 & 31.70 & sand, clay and gravel & Silty gravel. \\
\hline USGS UZB-2 & 31.70 & 32.31 & sand and clay & Silty sand. \\
\hline USGS UZB-2 & 32.31 & 33.53 & sand, clay and gravel & Silty gravel. \\
\hline USGS UZB-2 & 33.53 & 35.05 & sand and trace gravel & Gravelly sand. \\
\hline USGS UZB-2 & 35.05 & 39.32 & sand, clay and gravel & Clayey sandy gravel. \\
\hline USGS UZB-2 & 39.32 & 40.54 & sand and gravel & Sandy gravel. \\
\hline USGS UZB-2 & 40.54 & 40.84 & Gravel & Gravel. \\
\hline
\end{tabular}


Appendix 1. Compilation of borehole and aquifer data.-Continued

[cm, centimeter; $\mathrm{m}$, meter; in, inch; ft, feet; \%, percent; ppm, parts per million; $\approx$, approximately equal to; >, greater than]

\begin{tabular}{|c|c|c|c|c|}
\hline Bore & $\begin{array}{l}\text { Top } \\
\text { (m) }\end{array}$ & $\begin{array}{c}\text { Bottom } \\
\text { (m) }\end{array}$ & Simplified lithology & Driller's description \\
\hline USGS UZB-2 & 40.84 & 41.45 & clay, sand and gravel & Clayey gravel. \\
\hline USGS UZB-2 & 41.45 & 42.67 & clay, sand and gravel & Clayey gravelly sand. \\
\hline USGS UZB-2 & 43.59 & 57.91 & sand, clay and gravel & Clayey sandy gravel. \\
\hline USGS UZB-2 & 57.91 & 58.22 & sand, clay and gravel & Silty gravel. \\
\hline USGS UZB-2 & 61.87 & 63.70 & sand and trace gravel & Gravelly sand. \\
\hline USGS UZB-2 & 63.70 & 72.24 & $\begin{array}{l}\text { sand, clay and trace } \\
\text { gravel }\end{array}$ & Sandy clayey gravel. \\
\hline USGS UZB-2 & 72.24 & 79.25 & sand and gravel & Sandy gravel. \\
\hline USGS UZB-2 & 79.25 & 81.99 & clay, sand and gravel & Sandy silty gravel. \\
\hline USGS UZB-2 & 86.56 & 87.48 & clay and sand & Clayey sandy silt. \\
\hline USGS UZB-2 & 87.48 & 98.15 & $\begin{array}{l}\text { sand, clay and trace } \\
\text { gravel }\end{array}$ & Gravelly silt. \\
\hline USGS UZB-2 & 98.15 & 100.58 & sand, clay and gravel & Silty gravel. \\
\hline USGS UZB-2 & 100.58 & 104.24 & clay & Clay. \\
\hline USGS UZB-2 & 104.24 & 106.68 & clay, sand and gravel & Clayey gravel. \\
\hline USGS UZB-2 & 106.68 & 107.90 & sand, clay and gravel & Silty gravel. \\
\hline USGS UZB-2 & 107.90 & 111.25 & clay, sand and gravel & Clayey gravel. \\
\hline
\end{tabular}


Appendix 1. Compilation of borehole and aquifer data.-Continued

[cm, centimeter; $\mathrm{m}$, meter; in, inch; ft, feet; \%, percent; ppm, parts per million; $\approx$, approximately equal to; >, greater than]

\begin{tabular}{|c|c|c|c|c|}
\hline Bore & $\begin{array}{l}\text { Top } \\
\text { (m) }\end{array}$ & $\begin{array}{c}\text { Bottom } \\
\text { (m) }\end{array}$ & Simplified lithology & Driller's description \\
\hline USGS UZB-2 & 111.25 & 113.39 & sand, clay and gravel & Silty gravel. \\
\hline USGS UZB-2 & 113.39 & 114.60 & Gravel & $\begin{array}{l}\text { Gravel. Note: Casing broke at } 200 \mathrm{ft} \text { below land surface, } \\
\text { casing was no retrieved, total length of casing left in } \\
\text { ground was } 100 \mathrm{ft} \text {, from } 200-300 \mathrm{ft} \text { below land surface. }\end{array}$ \\
\hline USGS UZB-3 & 0.00 & 0.61 & clay and sand & Sandy silt. \\
\hline USGS UZB-3 & 0.61 & 3.05 & sand, clay and gravel & Silty sandy gravel. \\
\hline USGS UZB-3 & 4.88 & 6.71 & sand, clay and gravel & Silty sandy gravel. \\
\hline USGS UZB-3 & 6.71 & 7.32 & clay and sand & Sandy silt. \\
\hline USGS UZB-3 & 7.32 & 10.67 & sand and gravel & Sandy gravel. \\
\hline USGS UZB-3 & 10.67 & 10.97 & sand, clay and gravel & Silty sandy gravel. \\
\hline USGS UZB-3 & 14.94 & 18.90 & sand, clay and gravel & Silty sandy gravel. \\
\hline USGS UZB-3 & 18.90 & 19.51 & sand and clay & Silty sand. \\
\hline USGS UZB-3 & 19.51 & 22.56 & sand, clay and gravel & Silty sandy gravel. \\
\hline USGS UZB-3 & 22.56 & 23.16 & sand, clay and gravel & Gravel with silt and sand. \\
\hline USGS UZB-3 & 23.16 & 25.60 & sand and gravel & coarse sand and gravel. \\
\hline USGS UZB-3 & 25.60 & 30.78 & sand, clay and gravel & Silty sand and gravel. \\
\hline USGS UZB-3 & 30.78 & 33.53 & sand and gravel & Sandy gravel (damp). \\
\hline USGS UZB-3 & 33.53 & 56.69 & sand, clay and gravel & Silty sandy gravel beds. \\
\hline
\end{tabular}


Appendix 1. Compilation of borehole and aquifer data.-Continued

[cm, centimeter; $\mathrm{m}$, meter; in, inch; ft, feet; \%, percent; ppm, parts per million; $\approx$, approximately equal to; >, greater than]

\begin{tabular}{|c|c|c|c|c|}
\hline Bore & $\begin{array}{l}\text { Top } \\
\text { (m) }\end{array}$ & $\begin{array}{c}\text { Bottom } \\
\text { (m) }\end{array}$ & Simplified lithology & Driller's description \\
\hline USGS UZB-3 & 56.69 & 60.96 & clay, sand and gravel & Silt, sand and clay with gravel. \\
\hline USGS UZB-3 & 60.96 & 65.84 & sand, clay and gravel & Silty sandy gravel. \\
\hline USGS UZB-3 & 67.06 & 67.67 & sand, clay and gravel & Silty sandy gravel. \\
\hline USGS UZB-3 & 67.67 & 69.80 & sand and gravel & Sandy gravel. \\
\hline USGS UZB-3 & 70.10 & 71.93 & sand and gravel & Sand gravel. \\
\hline USGS UZB-3 & 71.93 & 72.54 & sand and gravel & Sand and gravel. \\
\hline USGS UZB-3 & 72.54 & 73.15 & sand, clay and gravel & Silty sandy gravel. \\
\hline USGS UZB-3 & 73.15 & 84.12 & sand, clay and gravel & Silty sand and gravel. \\
\hline USGS UZB-3 & 84.12 & 87.17 & sand and clay & Silty sand with clay. \\
\hline USGS UZB-3 & 93.88 & 97.23 & sand, clay and gravel & Silty sandy gravel. \\
\hline USGS UZB-3 & 97.23 & 98.45 & sand and clay & Silty sand. \\
\hline USGS UZB-3 & 98.45 & 104.55 & clay and sand & Sandy silt. \\
\hline USGS UZB-3 & 104.55 & 105.16 & sand, clay and gravel & Silt with sand and gravel. \\
\hline USGS UZB-3 & 105.16 & 109.12 & sand and gravel & Sandy gravel. \\
\hline USGS UZB-3 & 109.12 & 111.86 & sand, clay and gravel & Silty gravel with boulders. \\
\hline USGS UZB-3 & 111.86 & 114.30 & sand, clay and gravel & Silty gravel. \\
\hline
\end{tabular}


Appendix 1. Compilation of borehole and aquifer data.-Continued

[cm, centimeter; $\mathrm{m}$, meter; in, inch; ft, feet; $\%$, percent; ppm, parts per million; $\approx$, approximately equal to; >, greater than]

\begin{tabular}{|c|c|c|c|c|}
\hline Bore & Water depth (ft) & Total depth (ft) & Water depth (m) & Total depth (m) \\
\hline AquAeTer MW-318 & 285 & 300 & 86.80 & 91.44 \\
\hline AquAeTer MW-319 & 290 & 318 & 88.45 & 96.93 \\
\hline AquAeter MW-325 & 362 & 389 & 110.40 & 118.57 \\
\hline AquAeTer MW-326 & 360 & 372 & 109.60 & 113.39 \\
\hline AquAeTer MW-327 & 338 & 360 & 103.10 & 109.73 \\
\hline G\&M Inc 001 & 341 & 366 & 103.94 & 111.63 \\
\hline G\&M Inc 002 & 356 & 390 & 108.51 & 118.87 \\
\hline G\&M Inc 600 & 307 & 502 & 93.45 & 153.01 \\
\hline G\&M Inc 601 & 325 & 420 & 98.99 & 128.02 \\
\hline G\&M Inc 602 & 328 & 415 & 100.07 & 126.49 \\
\hline G\&M Inc 603 & 322 & 415 & 98.13 & 126.49 \\
\hline G\&M Inc 604 & 322 & 436 & 98.15 & 132.95 \\
\hline G\&M Inc 605 & 320 & 442 & 97.43 & 134.66 \\
\hline GSI 304 & 288 & 380 & 87.78 & 115.82 \\
\hline GSI 305 & 283 & 380 & 86.26 & 115.82 \\
\hline GSI 306 & 300 & 380 & 91.44 & 115.82 \\
\hline Mark Group 308 & 303 & 338 & 92.48 & 103.02 \\
\hline Mark Group 309 & 309 & 340 & 94.34 & 103.63 \\
\hline Mark Group 310 & 282 & 302 & 86.11 & 92.20 \\
\hline Mark Group 311 & 304 & 330 & 92.78 & 100.58 \\
\hline Mark Group 312 & 284 & 305 & 86.72 & 92.96 \\
\hline Mark Group 312A & 285 & 301 & 87.02 & 91.90 \\
\hline Mark Group 313 & 287 & 320 & 87.54 & 97.54 \\
\hline Mark Group 314 & 302 & 336 & 92.14 & 102.41 \\
\hline Mark Group 315 & 306 & 340 & 93.16 & 103.63 \\
\hline Mark Group 316 & 290 & 310 & 88.24 & 94.49 \\
\hline Mark Group 317 & 306 & 340 & 93.40 & 103.63 \\
\hline Mark Group 400 & 283 & 537 & 86.32 & 163.68 \\
\hline Mark Group 401 & 287 & 420 & 87.48 & 128.02 \\
\hline Mark Group 402C & 282 & 436 & 86.01 & 132.89 \\
\hline Mark Group 403 & 301 & 658 & 91.71 & 200.56 \\
\hline Perk Est. ARAS1 & 46 & 153 & 14.17 & 46.49 \\
\hline Perk Est. ARRB1 & 49 & 159 & 14.80 & 48.50 \\
\hline Site Well 1961 & 315 & 575 & 96.01 & 175.26 \\
\hline USGS MR3 & 369 & 405 & 112.47 & 123.44 \\
\hline USGS No 1 & 326 & 574 & 99.36 & 175.00 \\
\hline USGS UZB-1 & 145 & 158 & 44.20 & 48.25 \\
\hline USGS UZB-2 & 358 & 376 & 108.98 & 114.66 \\
\hline USGS UZB-3 & 361 & 375 & 110.03 & 114.45 \\
\hline
\end{tabular}


Publishing support provided by:

Denver Publishing Service Center

For more information concerning this publication, contact:

Center Director, USGS Geology and Environmental Change Science Center

Box 25046, Mail Stop 980

Denver, CO 80225

(303) 236-5344

Or visit the Geology and Environmental Change Science Center Web site at: http://esp.cr.usgs.gov/ 
